PRISCILA DE FIGUEIREDO AQUINO CARDOSO

\title{
ANÁLISE DE EXPERIÊNCIAS DE EDUCAÇÃO PERMANENTE NA GESTÃO FEDERAL DO SISTEMA ÚNICO DE SAÚDE
}

Brasília

Faculdade de Ciências da Saúde

Universidade de Brasília

2016 


\author{
UNIVERSIDADE DE BRASÍLIA \\ FACULDADE DE CIÊNCIAS DA SAÚDE \\ PROGRAMA DE PÓS-GRADUAÇÃO EM CIÊNCIAS DA SAÚDE
}

PRISCILA DE FIGUEIREDO AQUINO CARDOSO

\title{
ANÁLISE DE EXPERIÊNCIAS DE EDUCAÇÃO PERMANENTE NA GESTÃO FEDERAL DO SISTEMA ÚNICO DE SAÚDE
}

Dissertação apresentada como requisito parcial para a obtenção do título de Mestre em Saúde Coletiva pelo Programa de Pós-Graduação em Saúde Coletiva da Universidade de Brasília.

Orientadora: Magda Duarte dos Anjos Scherer

\section{Brasília}

Faculdade de Ciências da Saúde

Universidade de Brasília

2016 


\title{
ANÁLISE DE EXPERIÊNCIAS DE EDUCAÇÃO PERMANENTE NA GESTÃO FEDERAL DO SISTEMA ÚNICO DE SAÚDE
}

\author{
Dissertação apresentada como requisito \\ parcial para a obtenção do título de \\ Mestre em Saúde Coletiva pelo Programa \\ de Pós-Graduação em Saúde Coletiva da \\ Universidade de Brasília.
}

Aprovada em 05 de dezembro de 2016.

\section{BANCA EXAMINADORA}

\author{
Magda Duarte dos Anjos Scherer (Presidente) \\ Universidade de Brasília
}

\section{Wania Maria do Espírito Santo Carvalho}

Fundação de Ensino e Pesquisa em Ciências da Saúde/ Secretaria de Saúde do DF

\author{
Maria Fabiana Damásio Passos \\ Fundação Oswaldo Cruz
}

Brasília

Faculdade de Ciências da Saúde

Universidade de Brasília

2016 


\section{AGRADECIMENTOS}

São muitas as pessoas a quem devo agradecer. Essa tarefa é bem delicada, pois é um risco deixar alguém fora dessa lista. Mas vamos lá! Agradeço, em primeiro lugar, aos meus pais pelo apoio incondicional na minha formação pessoal e profissional, orientada por valores morais e éticos inquestionáveis.

À minha irmã, Camila, pela parceria e amizade que serão eternas! Em seguida, agradeço à minha amiga Juliana Mota Loureiro por ter me incentivado a participar do processo seletivo para o Mestrado Profissionalizante e por ter me apoiado em diversos momentos em que tive dúvida se daria ou não continuidade a essa empreitada.

Agradeço, também, ao meu marido, Rodrigo Cardoso, que pacientemente me "aturou", especialmente nos últimos meses tensos de elaboração do texto final da dissertação.

Às minhas filhas, que certamente sentiram minha falta em alguns momentos nesses dois anos de estudos, mas que sempre me deram força para seguir em frente, mesmo sem perceberem.

À minha amiga Carla Lourenzatto, que, bravamente, esteve comigo no início do Mestrado e sempre apoiou essa e outras decisões minhas. À Teresa Passarella, minha coordenadora, que tanto me ajudou com sugestão de textos e diálogos enriquecedores.

À colega Ana Beatriz Cabral, pela leitura crítica e por todas as orientações acerca deste trabalho.

À minha querida amiga Kelly Fernandes da Silva, que sempre me apoiou neste e em tantos outros desafios do cotidiano do nosso trabalho no Ministério da Saúde. À minha colega de mestrado Ana Silvia Pavani Lemos, pelo incentivo e também pelas valiosas contribuições textuais.

À querida Fabiana Damásio, pela parceria de sempre e por aceitar o convite para compor minha banca.

Aos colegas Diogo Fonseca e Rosângela Franzese, que, nos momentos finais, me presentearam com contribuições valorosas. 
À minha coordenadora, Delciene Pereira, pelo apoio e compreensão, especialmente em relação às "ausências" do trabalho nos momentos finais de elaboração desta dissertação. Por fim, e não menos importante, à minha querida orientadora Magda Duarte dos Anjos Scherer, pela paciência, persistência, incentivo e provocações reflexivas acerca da temática desse estudo. 
"Ninguém educa ninguém, ninguém educa a si mesmo, os homens se educam entre si, mediatizados pelo mundo". Paulo Freire 


\section{RESUMO}

Este estudo, de caráter qualitativo, apresenta uma análise do processo de implementação da Educação Permanente em Saúde na gestão federal do Sistema Único de Saúde (SUS) no contexto das experiências apresentadas na 1aㅡ Mostra Nacional de Educação Permanente em Saúde. A metodologia adotada consiste na análise temática de conteúdo das narrativas dessas experiências. Após uma leitura flutuante e adoção de critérios de inclusão e exclusão, foram objeto de estudo e análise 56 narrativas de experiências da gestão federal do SUS. Para tanto, foi construído um quadro analítico, a partir do qual foram identificados temas/categorias que trazem como resultados as principais concepções de educação presentes nas narrativas, bem como a correlação entre as experiências e as diretrizes da Política Nacional de Educação Permanente em Saúde (Pneps) e as mudanças ocorridas nos processos de trabalho das unidades da gestão federal do SUS que foram contempladas na Coletânea de Narrativas da referida 1aㅡ Mostra Nacional. Os dados encontrados sugerem a necessidade de aprofundamento nas discussões sobre a Educação Permanente e também de fortalecimento da Pneps na gestão federal do SUS por meio da formação de ativadores de processos de EP.

Palavras-chave: Educação em Saúde; Educação; Educação Continuada; Formação Profissional. 


\section{ABSTRACT}

This qualitative study presents an analysis of the implementation process of Permanent Education in Health in the federal management of the Unified Health System (SUS) in the context of the experiences presented at the I National Showing of Permanent Education in Health. The methodology, presented in this study, consists in a content analysis of the narratives of these experiences. After a floating reading and adoption of inclusion and exclusion criteria, 56 narratives of experiences of SUS' federal management were the object of study and analysis. For that, an analytical framework was created bringing as results the main conceptions of education present in the narratives, the correlation between the experiences and the directives of the National Policy of Permanent Education in Health (PNEPS) and the changes that occurred in the work processes of the federal SUS' management units can be considerate part of the results as well. All those results were included in the Narratives Collection of the I National Showing. The data founded in this study suggest the need to deepen the discussions about Permanent Education and to strengthen PNEPS in the federal SUS management through the training of EP process activators.

Keywords: Education in Health; Education; Continuing Education; Vocational Training. 


\section{LISTA DE QUADROS E TABELAS}

\section{QUADROS}

1 - Comparativo entre educação continuada e educação permanente. .35

2 - Relação entre autores/ referências e concepções de educação. 38

3 - Total de órgãos existentes na estrutura do MS; órgãos do MS com narrativas publicadas na Coletânea; e Unidades da Federação/ Região que representam.

4 - Correlação entre ações, métodos, objetivos e a diretriz da PNEPS correspondente (Realização de práticas educacionais em espaços coletivos de trabalho)

5 - Correlação entre ações, métodos, objetivos e a diretriz da PNEPS correspondente (Contribuição para o enfrentamento da fragmentação dos serviços e ações de saúde).

6 - Correlação entre ações, métodos, objetivos e a diretriz da PNEPS correspondente (Valorização do trabalhador e do trabalho em saúde)

7 - Correlação entre ações, métodos, objetivos e a diretriz da PNEPS correspondente (Promoção de aprendizagem significativa com uso de metodologias ativas e críticas)

8 - Correlação entre ações, métodos, objetivos e a diretriz da PNEPS correspondente (Favorecimento de autonomia e corresponsabilização de sujeitos nos processos de trabalho).

9 - Correlação entre ações, métodos, objetivos e a diretriz da PNEPS correspondente (Fortalecimento da gestão da educação permanente em saúde de forma compartilhada e participativa).

10 - Correlação entre ações, métodos, objetivos e a diretriz da PNEPS correspondente (Contribuição para a mudança cultural e institucional direcionada à gestão compartilhada e ao aprimoramento do SUS).

11 - Correlação entre ações, métodos, objetivos e a diretriz da PNEPS correspondente (Valorização das múltiplas dimensões humanas nos processos de ensino-aprendizagem).

12 - Correlação entre concepções de educação e o tema "Compartilhamento de informações e saberes". 
13 - Correlação entre concepções de educação e o tema "Trabalho como espaço de aprendizado".

14 - Correlação entre concepções de educação e o tema "Reflexão sobre a prática".

15 - Correlação entre concepções de educação e o tema "Desenvolvimento pessoal e organizacional".

16 - Correlação entre concepções de educação e 0 tema "Problematização".

17 - Correlação entre concepções de educação e o tema "Aprendizagem significativa".

18 - Correlação entre concepções de educação e o tema "Valorização de saberes prévios" e outros temas correlatos. .66

19 - Correlação entre concepções de educação e o tema "Aprendizagem em serviço". 66

20 - Correlação entre concepções de educação e o tema "Transformação de práticas".

21 - Correlação entre concepções de educação e o tema "Análise do cotidiano do trabalho".

22 - Correlação entre concepções de educação e o tema "Valorização e humanização dos profissionais". .68

23 - Correlação entre métodos, objetivos e as principais mudanças ocorridas a partir da experiência relatada (Qualificação de processos de trabalho). .70 24 - Correlação entre métodos, objetivos e as principais mudanças ocorridas a partir da experiência relatada (Integração entre equipes). 25 - Correlação entre métodos, objetivos e as principais mudanças ocorridas a partir da experiência relatada (Aprendizagem no trabalho) 72 26 - Correlação entre métodos, objetivos e as principais mudanças ocorridas a partir da experiência relatada (Satisfação do usuário/ Integração entre equipes). .74

\section{TABELAS}

1 - Quantitativo de narrativas segundo as diretrizes da PNEPS.

2 - Quantitativo de narrativas segundo temas relacionados às concepções de educação identificadas. 
3 - Quantitativo de narrativas segundo temas relacionados às mudanças ocorridas a partir das experiências relatadas .............................................................69 4 - Quantitativo de narrativas, segundo conjunto de temas relacionados às mudanças ocorridas a partir das experiências relatadas.....................................69 


\section{LISTA DE ABREVIATURAS E SIGLAS}

AIS - Agente Indígena de Saúde

Aisan - Agente Indígena de Saneamento

Casai - Casa de Saúde Indígena

Cgesp -Coordenação-Geral de Gestão de Pessoas

CGU - Controladoria-Geral da União

CLT - Consolidação das Leis do Trabalho

CNS - Conselho Nacional de Saúde

Codep - Coordenação de Desenvolvimento de Pessoas

Conass - Conselho Nacional de Secretários de Saúde

DataSUS - Departamento de Informática do SUS

DDAHV - Departamento de DST, Aids e Hepatites Virais

Deges - Departamento de Gestão da Educação na Saúde

Dsei - Distrito Sanitário Especial Indígena

Emsi - Equipes Multidisciplinares de Saúde Indígena

EP - Educação Permanente

Episus - Programa de Treinamento em Serviço da Secretaria de Vigilância em Saúde do Ministério da Saúde

EPS - Educação Permanente em Saúde

Fiocruz - Fundação Oswaldo Cruz

Funai - Fundação Nacional do Índio

Hemobrás - Empresa Brasileira de Hemoderivados e Biotecnologia

Inca - Instituto Nacional de Câncer José Alencar Gomes da Silva

Into - Instituto Nacional de Traumatologia e Ortopedia Jamil Haddad

MS - Ministério da Saúde

Nems - Núcleo Estadual do Ministério da Saúde

Nerj - Núcleo Estadual do Rio de Janeiro

Opas - Organização Pan-Americana de Saúde

Pneps - Política Nacional de Educação Permanente em Saúde

SciELO - Scientific Electronic Library Online

SGTES - Secretaria de Gestão do Trabalho e da Educação na Saúde

Siconv - Sistema de Convênios

sus- Sistema Único de Saúde 
UFRGS - Universidade Federal do Rio Grande do Sul

UFSC - Universidade Federal de Santa Catarina

Unesco - Organização das Nações Unidas para a Educação, a Ciência e a Cultura VAN - Vigilância Alimentar e Nutricional 


\section{SUMÁRIO}

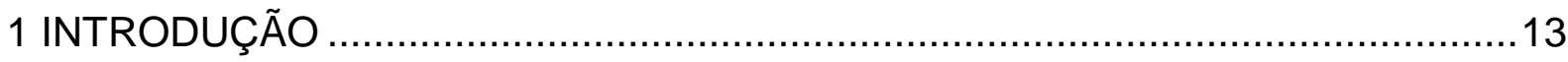

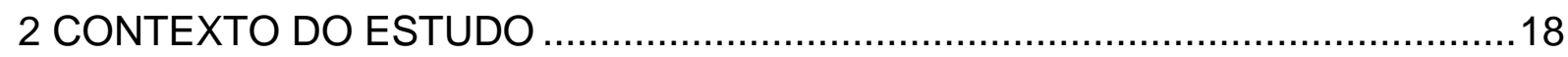

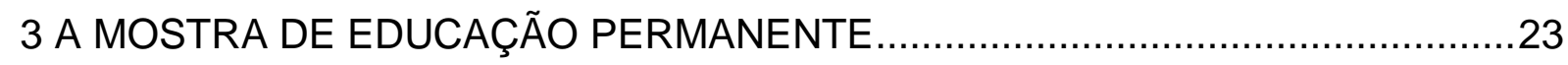

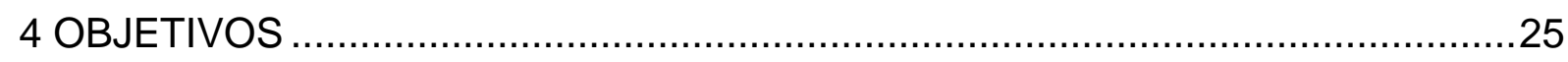

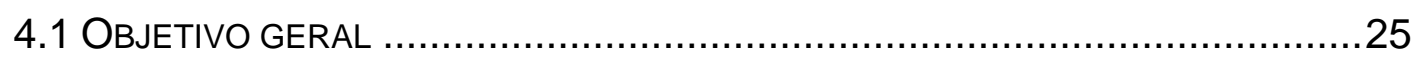

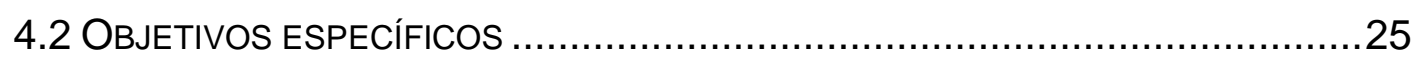

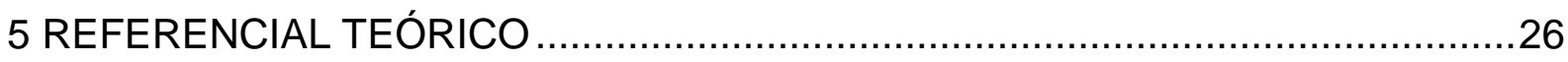

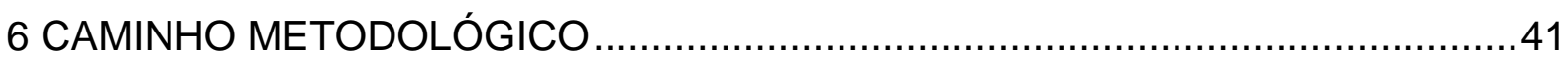

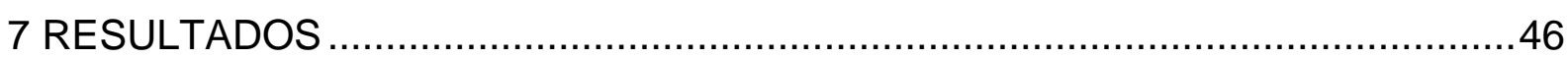

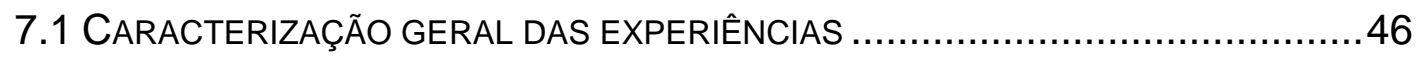

7.2 COMO AS AÇÕES REALIZADAS NA GESTÃO FEDERAL DO SUS SE CORRELACIONAM COM AS DIRETRIZES DA PolítICA NACIONAL DE EdUCAÇÃO Permanente em Saúde?

7.3 QUAIS CONCEPÇÕES DE EDUCAÇÃO SÃO APRESENTADAS NAS NARRATIVAS DE EXPERIÊNCIAS DA 1 a MOSTRA NACIONAL? .58

7.4 QUAIS MUDANÇAS PODEM SER IDENTIFICADAS NOS PROCESSOS DE TRABALHO OU NAS INSTITUIÇÕES A PARTIR DAS EXPERIÊNCIAS APRESENTADAS NA $1^{\circledR}$ MOSTRA NACIONAL? .68

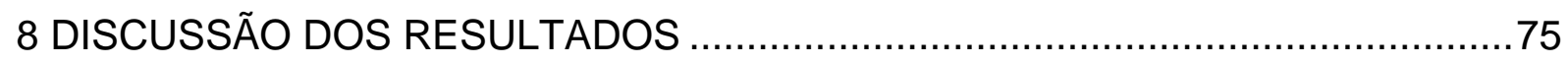

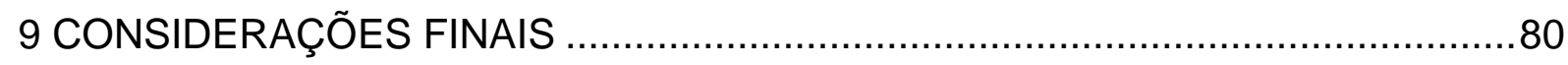

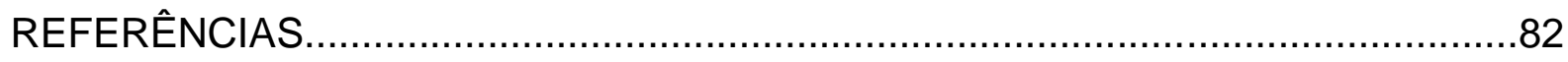

ANEXO A - PARECER CONSUBSTANCIADO DO CEP......................................87

APÊNDICE A - QUADRO ANALÍTICO DAS NARRATIVAS.....................................91 


\section{INTRODUÇÃO}

Durante um longo período, que se iniciou nos anos 1950 e se estendeu até meados de 1980, a preocupação dos gestores públicos na área da saúde voltava-se principalmente para o financiamento e a organização da assistência à saúde. tema "recursos humanos" na saúde era visto como um insumo, ao lado dos recursos materiais e financeiros. Somente nas décadas de 1980 e 1990, a partir da reestruturação produtiva, ${ }^{1}$ a discussão sobre o novo paradigma do trabalho nas sociedades pós-industriais toma como foco o trabalhador, ampliando a discussão sobre a gestão do trabalho, incluindo estratégias de repensar o planejamento e a qualificação do trabalho e do trabalhador (CONASS, 2011).

Com as mudanças ocorridas no mundo do trabalho a partir da década de 1980 (reestruturação produtiva, incorporação tecnológica), especificamente no campo da saúde, passa-se a exigir novas competências dos trabalhadores. No trabalho em saúde, o foco principal está nas pessoas, portanto o processo de trabalho pauta-se pelo contato humano. Assim, as tendências nesse campo direcionam para uma formação mais polivalente, no sentido da multiqualificação, que segundo Deluiz (1996, apud CONASS, 2011, p. 15), é quando "o trabalhador opera diferentes atividades com níveis de complexidade equivalentes ou uma atividade principal e outras correlatas".

Os processos de gestão do trabalho em saúde são caracterizados pela complexidade, heterogeneidade e fragmentação. Eles são complexos em razão da diversidade de recursos envolvidos, incluindo profissões, profissionais, usuários, recursos tecnológicos, além das relações sociais e interpessoais, das formas de organização do trabalho, dos espaços e ambientes de trabalho. São heterogêneos diante da diversidade de processos de trabalho existentes nas instituições de saúde, que, muitas vezes, não se articulam com os demais processos de trabalho. Já a fragmentação dos processos de gestão do trabalho em saúde contempla várias

\footnotetext{
1 "Termo que engloba o grande processo de mudanças ocorridas nas empresas e principalmente na organização do trabalho industrial nos últimos tempos, pela introdução de inovações tanto tecnológicas como organizacionais e de gestão, buscando-se alcançar uma organização do trabalho integrada e flexível. Entre as mudanças organizacionais, destacam-se a redução dos níveis hierárquicos, a polivalência e multifuncionalidade do trabalhador, o trabalho em grupos, a mão de obra com maior capacitação e disposta a participar, a aprendizagem, a autonomia, a cooperação, diferenciando-se da lógica da especialização intensiva do trabalho" (GARAY; SCHEFFER apud CONASS, 2011, p. 12)
} 
dimensões, como: I) a fragmentação conceitual, que consiste na separação entre o pensar e o fazer; ii) a fragmentação técnica, tendo em vista a crescente presença de profissionais especializados; e iii) a fragmentação social, que contempla as relações de hierarquia e subordinação, determinando a organização do trabalho (DELUIZ apud QUINTANA et al. 1994). Ainda no que se refere à fragmentação técnica, a incorporação de novas tecnologias no setor saúde vem trazendo novos serviços e ocupações, aumentando a necessidade de profissionais qualificados.

A qualificação dos trabalhadores da saúde está prevista tanto na Constituição Federal, em seu artigo 200, inciso III, quando afirma que compete ao Sistema Único de Saúde (SUS) "ordenar a formação de recursos humanos na área de Saúde", quanto na Lei Orgânica da Saúde, a Lei Federal no 8.080, de 19 de setembro de 1990.

Esse tema também foi objeto de discussão durante a XI Conferência Nacional de Saúde, que apontou a necessidade de se formular uma Norma Operacional Básica de Recursos Humanos que viabilizasse uma diretriz clara para a gestão dos trabalhadores em saúde, tanto no que diz respeito às condições de trabalho (formas de vínculo empregatício, carga horária, piso salarial) quanto à formação profissional dos trabalhadores em saúde.

O planejamento de ações educativas voltadas ao desenvolvimento de todos os trabalhadores é fator básico para o fortalecimento da capacidade gestora da instituição para criação de uma identidade institucional e, em última instância, para promover o aprendizado organizacional.

Sobre os processos de desenvolvimento dos trabalhadores da área da saúde, Ceccim (2005) faz a crítica de que as capacitações não são suficientemente eficazes para possibilitar a incorporação de novos conceitos e princípios às práticas estabelecidas, pois normalmente são trabalhadas de forma descontextualizada e se baseiam simplesmente na transmissão de conhecimentos. $O$ autor defende a Educação Permanente em Saúde como orientadora de iniciativas de desenvolvimento dos profissionais e das estratégias de transformação das práticas de saúde e considera que o trabalho é ambiente de aprendizado.

Dessa forma, foi instituída, em 2004, a Política Nacional de Educação Permanente em Saúde (Pneps), direcionada ao desenvolvimento de profissionais de saúde de estados e de municípios. No entanto, somente em 2012 passou-se a discutir as diretrizes para a implementação dessa Política no âmbito da gestão 
federal do SUS para os trabalhadores do Ministério da Saúde (MS). Como resultado dessa discussão, foi publicada uma portaria ministerial em 2014, reafirmando os princípios e diretrizes da Educação Permanente como estratégia para a formação e o desenvolvimento dos trabalhadores do Ministério que atuam em Brasília e nas unidades localizadas nos 26 estados brasileiros.

A Pneps contribui para o enfrentamento dos principais problemas na gestão, como: i) a baixa capacidade gerencial; ii) a ausência de pessoal qualificado; iii) o desconhecimento sobre os princípios e as normas operacionais do SUS; iv) a falta de conhecimento de gestores e trabalhadores sobre as bases técnicas e políticas do SUS; e v) pouca oferta de qualificação na área de Saúde Pública e Gestão de Serviços de Saúde. (CONASS, 2011)

A contribuição da Política para superação desses problemas se dá por meio da implementação das suas diretrizes no âmbito do Ministério da Saúde:

[...] I. valorizar o trabalhador e o trabalho em saúde no Ministério da Saúde, na perspectiva da Política Nacional de Humanização da Atenção e Gestão no SUS;

II. fomentar práticas educacionais em espaços coletivos de trabalho, fortalecendo o trabalho em equipes multiprofissionais;

III. promover a aprendizagem significativa por meio da adoção de metodologias ativas e críticas;

IV. favorecer a autonomia dos sujeitos e a corresponsabilização nos processos de trabalho do Ministério da Saúde;

V. articular a Educação Permanente em Saúde e a gestão de pessoas por competências para a organização das ações de educação no Ministério da Saúde;

VI. fortalecer a gestão da Educação Permanente em Saúde de forma compartilhada e participativa no âmbito do Ministério da Saúde;

VII. contribuir para a mudança cultural e institucional direcionada à gestão compartilhada e ao aprimoramento do SUS;

VIII. constituir-se como uma estratégia política para o enfrentamento da fragmentação dos serviços e das ações de saúde; e

IX. valorizar as múltiplas dimensões humanas nos processos de ensinoaprendizagem. (BRASIL, 2014)

Alguns dos problemas na gestão mencionados anteriormente também se apresentaram no momento de construção das propostas de ações educativas direcionadas aos trabalhadores do Ministério da Saúde, quando se iniciou, em 2012, o processo interno de implementação das diretrizes da Pneps na gestão federal do SUS. A problematização das situações enfrentadas no cotidiano do trabalho em saúde foi a metodologia adotada pelo Ministério da Saúde para provocar a construção de uma agenda de prioridades de ações de desenvolvimento e formação para os trabalhadores do Ministério. (BRASIL, 2014, p. 15) 
O interesse em desenvolver esta pesquisa surgiu em decorrência das inquietações e experiência da pesquisadora enquanto gestora na Coordenação de Desenvolvimento de Pessoas (Codep) do Ministério da Saúde, envolvida na discussão da implementação das diretrizes da Pneps no âmbito do MS. A pesquisadora atua nessa Coordenação desde 2011, acompanhando junto à equipe técnica a evolução do processo de educação que vem se qualificando para superar a lógica de atendimento de demandas individuais de capacitação e também da compra e do pagamento de pacotes prontos de cursos padronizados e que, muitas vezes, não correspondem às necessidades organizacionais para qualificação dos trabalhadores do Ministério da Saúde em âmbito nacional.

Com a aproximação que houve em relação aos processos desenvolvidos na Codep, com foco nos trabalhadores da gestão federal do SUS, e na Secretaria de Gestão do Trabalho e da Educação na Saúde (SGTES), direcionados aos profissionais de saúde das esferas estadual e municipal, ocorrida a partir de 2012, as diretrizes da Pneps passaram a orientar, também, as ações desenvolvidas internamente no Ministério da Saúde.

Para reconhecer, valorizar e compartilhar as ações que estavam ocorrendo em todo o País no que se refere às práticas de Educação Permanente em Saúde, pensou-se em realizar uma mostra na qual qualquer trabalhador da gestão federal do SUS pudesse inscrever e apresentar sua experiência que, de alguma forma, tivesse promovido uma transformação em suas práticas cotidianas no trabalho. Seriam iniciativas de Educação Permanente em Saúde. A ideia era que todas as experiências pudessem ser compartilhadas. E assim aconteceu em dezembro de 2014 a 1를 Mostra Nacional de Educação Permanente em Saúde.

Logo após a realização da Mostra, reuniram-se, em uma publicação, cem narrativas de experiências de âmbito nacional, intitulada Coletânea de Narrativas: Experiências da I Mostra Nacional de Educação Permanente em Saúde reconhecendo as práticas dos trabalhadores do Ministério da Saúde.

Esta dissertação compreende a análise do processo de implementação da Educação Permanente em Saúde na gestão federal do SUS no contexto das experiências apresentadas na referida $1^{\text {a }}$ Mostra Nacional de Educação Permanente em Saúde. Dessa forma, este estudo apresenta uma relação entre o que a Política induz e o que se passa na realidade. 
Seguindo o caminho metodológico proposto neste trabalho, esta dissertação contempla, inicialmente, uma parte que trata do contexto do estudo com um breve histórico da discussão sobre a Pneps e sua implementação no Ministério da Saúde. Na sequência, um capítulo trata da Mostra de Educação Permanente. Em seguida, são apresentados os objetivos geral e específicos, acompanhados do referencial teórico adotado no estudo, do caminho metodológico e da organização da pesquisa. A parte seguinte apresenta os resultados da pesquisa, com: I) a caracterização geral das experiências; ii) as concepções de educação apresentadas pelos participantes da 1a Mostra Nacional de Educação Permanente em Saúde; iii) a relação entre as ações realizadas, conforme relatos/narrativas das experiências, e as diretrizes da Política Nacional de Educação Permanente em Saúde; e, por fim, iv) as principais mudanças ocorridas nos processos de trabalho das unidades que compõem a gestão federal do SUS. Ao final, apresenta-se a discussão dos resultados encontrados e a correlação com o que traz o referencial teórico adotado nesta pesquisa, concluindo este trabalho com as considerações finais da pesquisadora. 


\section{CONTEXTO DO ESTUDO}

Em 2004, o Ministério da Saúde instituiu a Política Nacional de Educação em Saúde (Pneps) como estratégia do SUS para a formação e o desenvolvimento de trabalhadores para o setor saúde, por meio de uma portaria ministerial. Essa Política surge num momento político favorável, corroborando a ideia de "janela de oportunidade política", de Kingdon (2003, p. 165-195). Para o autor, são três as condicionantes para a abertura dessa janela:

a) relevância do problema;

b) disponibilidade de ideias que permitam modificar a representação de um problema e o desenho de uma política pública; e

c) situação favorável a mudanças no sistema político (ex.: mudança de governo).

Além de o tema Educação Permanente em Saúde se apresentar como pauta recorrente nas Conferências Nacionais de Saúde, o momento político em que a Pneps foi instituída coincide com a mudança do governo e consequente mudança da gestão do Ministério da Saúde. Pouco antes da instituição da Pneps, houve a criação da Secretaria de Gestão do Trabalho e da Educação na Saúde (SGTES).

A SGTES, quando criada, em 2003, tinha como principal desafio trabalhar questões referentes à formação e ao desenvolvimento dos profissionais de saúde e questões relacionadas à gestão e regulação do trabalho no setor saúde. A partir desses desafios, o Departamento de Gestão da Educação na Saúde (Deges), da SGTES, passou a construir junto à Comissão Intersetorial de Recursos Humanos do Conselho Nacional de Saúde o que viria a compor futuramente a Pneps. Essa discussão e a construção da Pneps envolveram também instituições de ensino financiadas pelo Ministério da Saúde.

Até chegar à publicação da Pneps, "a educação permanente em saúde foi amplamente debatida pela sociedade brasileira organizada em torno da temática da saúde, tendo sido aprovada na XII Conferência Nacional de Saúde e no Conselho Nacional de Saúde (CNS) como política específica no interesse do sistema de saúde nacional" (CECCIM; FERLA, 2008, p. 163).

Isso se deu no ano de 2003, com a apresentação da proposta Política de Formação e Desenvolvimento para o SUS: caminhos para a Educação Permanente 
em Saúde. Em seguida, o próprio Conselho Nacional de Saúde publicou a Resolução n 335, de 2003, que afirma a aprovação da referida Política, bem como recomenda a sua implantação e implementação nas esferas federal, estadual e municipal (BRASIL, 2004).

A Pneps, quando instituída, se apresentou como uma proposta de ação visando contribuir para a transformação e qualificação das práticas de saúde, para a organização das ações e dos serviços de saúde, com os processos formativos e com as práticas pedagógicas na formação e no desenvolvimento dos trabalhadores de saúde.

A norma que institui a Pneps traz como conceito de Educação Permanente (EP) a "aprendizagem no trabalho, onde o aprender e o ensinar se incorporam ao quotidiano das organizações e ao trabalho" (BRASIL, 2004). E como proposta de atuação no campo da Política, sugere-se que:

[...] os processos de capacitação dos trabalhadores da saúde tomem como referência as necessidades de saúde das pessoas e das populações, da gestão setorial e do controle social em saúde, tenham como objetivos a transformação das práticas profissionais e da própria organização do trabalho e sejam estruturados a partir da problematização do processo de trabalho. (BRASIL, 2004)

A educação permanente, segundo a Pneps, traz como objeto de transformação o processo de trabalho, que passa a ser revalorizado como centro privilegiado de aprendizagem. Ela parte do pressuposto da aprendizagem significativa, ou seja, daquilo que traz sentido para o indivíduo envolvido no processo ao tempo em que deve provocar nesse indivíduo certo "desconforto" em situações vividas no trabalho.

Ao tomar como objeto de investigação e mudança o processo de trabalho, a EP pode contribuir para a diminuição da alienação e da burocratização, ampliar a capacidade de reflexão dos trabalhadores, melhorar a autoestima e a corresponsabilização, fomentando autonomia e criatividade com responsabilidade profissional. (BRASIL, 2014, p. 8).

Destaca-se que a forma de cuidar da saúde das pessoas está diretamente relacionada aos modos de ensinar e aprender. Dessa forma, para haver mudanças no sistema de saúde, é preciso investir nos processos de formação e desenvolvimento dos trabalhadores envolvidos no setor saúde. Nesses processos, deve-se levar em conta a realidade local, problematizando as situações do cotidiano do trabalho, envolvendo diferentes atores que atuam na área da saúde. 
Cabe destacar, ainda, que a implantação da Pneps não pressupõe a eliminação das capacitações tradicionais, mas visa promover, também, a educação que pensa o trabalho e a produção de mundo, com processos de reflexão crítica (BRASIL, 2004).

Segundo a Pneps, a formação e o desenvolvimento dos profissionais de saúde deve ocorrer de modo descentralizado, ascendente e transdisciplinar para propiciar: i) a democratização institucional; ii) o desenvolvimento da capacidade de aprendizagem; iii) o desenvolvimento de capacidades docentes e de enfrentamento criativo das situações de saúde; iv) o trabalho em equipes matriciais; v) a melhoria permanente da qualidade do cuidado à saúde; vi) a constituição de práticas tecnológicas, éticas e humanísticas.

Após três anos da publicação da portaria que instituiu a Pneps, uma nova norma é publicada, trazendo novas diretrizes e estratégias para sua implementação, adequando-as às diretrizes operacionais e ao regulamento do Pacto pela Saúde, ${ }^{2}$ instituído em 2006. Essa nova norma reafirma os princípios da EPS como norteadores para a construção dos Planos Regionais de Educação Permanente em Saúde e das ações educativas na saúde. Também é recolocada a questão de que as demandas para a formação e o desenvolvimento dos trabalhadores no SUS não sejam definidas somente a partir de uma lista de necessidades individuais de atualização e da capacidade de oferta e expertise de uma instituição de ensino, mas considerem, prioritariamente, os problemas cotidianos referentes à atenção à saúde e à organização do trabalho.

Com a nova normativa referente à Pneps, também é reafirmada a compreensão e o tratamento da gestão da educação na saúde (formação e desenvolvimento), não como uma questão simplesmente técnica, mas de natureza tecnopolítica, uma vez que envolve mudanças nas relações, nos processos, nos atos de saúde, nas organizações e nas pessoas. Dessa forma, apresenta-se a necessidade de uma articulação intra e interinstitucional que crie compromissos entre as diferentes redes de gestão, de serviços de saúde e educação e do controle social, possibilitando o enfrentamento dos problemas e maior efetividade das ações de saúde e educação.

\footnotetext{
${ }^{2}$ O Pacto pela Saúde é um conjunto de reformas institucionais do SUS pactuado entre as três esferas de gestão (União, Estados e Municípios) com o objetivo de promover inovações nos processos e instrumentos de gestão, visando alcançar maior eficiência e qualidade das respostas do Sistema Único de Saúde. (>http://conselho.saude.gov.br/webpacto/index.htm>)
} 
Outra questão trazida pela nova portaria da Pneps é que as ações de Educação na Saúde passam a compor o Pacto de Gestão, do Pacto pela Saúde. Assim, a responsabilidade pelas ações de educação na saúde passa a fazer parte da agenda da gestão do SUS.

Mesmo com toda a organização e disposição de diretrizes operacionais para implementação da Pneps, ainda persistem muitos desafios. Desde a sua implantação, em 2004, o MS tem enfrentado algumas dificuldades, especialmente em relação ao acompanhamento das ações desenvolvidas no âmbito dos estados e municípios. A desarticulação da Pneps com as demais políticas de educação na saúde e a baixa execução dos recursos por parte dos estados e escolas técnicas de saúde pública são alguns dos desafios a serem superados e que se apresentam na implementação dessa Política em âmbito nacional. Para enfrentar esses desafios, seria importante fortalecer parcerias e promover a articulação entre diferentes atores, o que traz à tona uma das características da Pneps: a interinstitucionalidade. Esta expressa a diversidade de atores sociais envolvidos, quais sejam: dirigentes, profissionais em formação, trabalhadores, estudantes ou usuários das ações e serviços de saúde (BRASIL, 2004).

Apesar de todo o processo de construção e discussão sobre a Pneps em âmbito nacional ter se fortalecido desde 2004, com sua institucionalização, somente em 2012, como já afirmado anteriormente, passou-se a discutir essa temática internamente no Ministério da Saúde, com foco em seus trabalhadores. Isso se configura como um dos maiores problemas enfrentados na implantação da Pneps na gestão federal do SUS: sua discussão fragmentada.

As mesmas dificuldades encontradas para implantação da Política no âmbito de estados e municípios, como baixa execução de recursos, por exemplo, se apresentaram quando se passou a discutir as diretrizes dessa Política na gestão federal do SUS e ainda hoje persistem.

A Cgesp do Ministério da Saúde é a área responsável por promover a discussão da Política e implementar as suas diretrizes com foco nos trabalhadores da gestão federal do SUS. No entanto, a partir de 2012, houve um processo de reflexão sobre a forma de se conduzir as ações de formação e desenvolvimento dos trabalhadores do MS, em âmbito nacional. Havia uma discussão interna sobre o impacto dos cursos ofertados aos servidores que, empiricamente, vinham demonstrando "uma reduzida capacidade de mudança dos processos de trabalho 
nos diversos setores do MS e pouca integração com o sistema de saúde nas suas esferas estaduais e municipais" (BRASIL, 2014, p. 14).

Com isso, a Cgesp, em articulação com o Deges/SGTES, passou a promover momentos de discussão para implementação das diretrizes da Pneps dentro do Ministério da Saúde, uma vez que o foco da Política, quando instituída em 2004, estava direcionado aos trabalhadores dos serviços de saúde, às instituições de ensino, à comunidade e aos gestores estaduais e municipais do SUS.

O primeiro momento de discussão da Pneps, no âmbito interno do Ministério da Saúde, ainda em 2012, consistiu num processo de planejamento participativo, com representantes de todas as Secretarias do Ministério para construção do chamado Plano de Educação Permanente do MS 2013 (PEP 2013). Foram realizadas oficinas separadamente por Secretaria, com o objetivo de discutir coletivamente acerca dos principais problemas e desafios relacionados aos processos de trabalho. A partir desses problemas e desafios, foram levantadas as principais ações educativas propostas, de forma a superá-los. Esse levantamento de ações educativas passou a fazer parte do Plano de Educação Permanente do MS 2013 (BRASIL, 2014).

Seguindo com a proposta de se implementarem as diretrizes da Pneps internamente no Ministério da Saúde, em 2013, foram estabelecidas parcerias com a Rede Governo Colaborativo em Saúde, ligada à Universidade Federal do Rio Grande do Sul (UFRGS) e com a Associação Brasileira Rede Unida. Também foram realizadas oficinas com a temática Educação Permanente como ferramenta de gestão, com os objetivos de reconhecer e cooperar com as ações de Educação Permanente que já existiam nas unidades do Ministério da Saúde. A partir dessas oficinas, que contaram novamente com a participação de representantes de todas as Secretarias do MS, foram identificadas demandas que passaram a compor a Agenda 2014 de Educação Permanente para os Trabalhadores do Ministério da Saúde. Entre as ações previstas nessa Agenda estava a Mostra de Educação Permanente, com o objetivo de reconhecer as ações de EP que acontecem em todo o País, na gestão federal do SUS, e Ihes dar visibilidade, de modo a fortalecê-la como norteadora de novas práticas que orientam a reflexão sobre os processos de trabalho (BRASIL, 2014). 


\section{A MOSTRA DE EDUCAÇÃO PERMANENTE}

Em princípio, a ideia de realizar uma Mostra de Educação Permanente em Saúde pareceu ousada, tendo em vista o pouco tempo de discussão da Pneps no âmbito interno do MS. No entanto, a Coordenação de Desenvolvimento de Pessoas, enquanto unidade do Ministério da Saúde responsável por conduzir processos voltados à formação e qualificação de profissionais que atuam na gestão federal do SUS, encarou o desafio mais como uma forma de colaborar para que iniciativas de educação permanente se tornassem visíveis e potentes, à medida que fossem compartilhadas com diferentes atores participantes da Mostra de diferentes regiões do País, mesmo com suas dificuldades e especificidades.

A 1aㅡ Mostra Nacional de Educação Permanente em Saúde foi realizada em dezembro de 2014 e organizada coletivamente por trabalhadores representantes de todas as secretarias do Ministério da Saúde. Este coletivo intersetorial compôs um grupo de trabalho para construção conjunta da chamada para inscrições de experiências em Educação Permanente em Saúde (EPS) e também para organização do evento. No total foram inscritas $165^{3}$ experiências de unidades da gestão federal do SUS espalhadas por todo o País.

A Mostra proporcionou que as experiências fossem compartilhadas com os presentes. E, para que todos tivessem acesso ao que foi apresentado na ocasião, surgiu a ideia de publicizar relatos das experiências apresentadas, incluindo as percepções de cada autor/ apresentador ao participar do evento. Assim, logo após a realização da Mostra, foi solicitado aos participantes o envio de textos reflexivos sobre as vivências trazidas para o evento para posterior publicação. Esses textos foram chamados de narrativas, pois além de apresentar as experiências em si, trazem o registro de "emoções e afetações mútuas de cada um".

As narrativas são livres e são construções pessoais, fruto da vivência e percepção de mundo de seus autores que, com protagonismo, lançam novos olhares sobre as formas de se fazer o trabalho em saúde. (BRASIL, 2015, p. 16)

\footnotetext{
${ }^{3}$ Quantitativo identificado a partir da relação de trabalhos que seriam apresentados na $1{ }^{\text {a }}$ Mostra Nacional de Educação Permanente pelo link: http://portalsaude.saude.gov.br/images/pdf/2014/novembro/19/165-Experi--ncias-Mostra-EP-1911.pdf.
} 
Com os relatos de experiências publicadas na Coletânea de Narrativas da $1^{a}$ Mostra Nacional de Educação Permanente em Saúde, foi possível realizar este estudo, que objetiva analisar a implementação da EP na gestão federal do SUS. 


\section{OBJETIVOS}

\subsection{Objetivo geral}

O objetivo geral deste trabalho é analisar o processo de implementação da Educação Permanente em Saúde na gestão federal do Sistema Único de Saúde no contexto das experiências apresentadas na 1a Mostra Nacional de Educação Permanente em Saúde.

\subsection{Objetivos específicos}

Os objetivos específicos da pesquisa são:

a) identificar as concepções de educação presentes nas narrativas de experiências apresentadas na 1aㅡ Mostra Nacional de Educação Permanente em Saúde;

b) correlacionar as ações realizadas na gestão federal do SUS e as diretrizes da Pneps; e

c) identificar as mudanças ocorridas nos processos de trabalho e/ou nas unidades da gestão federal do SUS segundo as experiências apresentadas na $1^{\text {a }}$ Mostra Nacional de Educação Permanente em Saúde. 


\section{REFERENCIAL TEÓRICO}

A discussão sobre a Educação Permanente não é algo recente. Ela surge inicialmente nos anos 1930; depois, mais fortemente, reaparece nos anos 1960, relacionada a ações de aprendizagem de adultos com foco na necessidade de reposicionamento das pessoas no mercado de trabalho decorrente da intensificação da industrialização e da urbanização. (FEUERWERKER, 2014)

Pierre Furter (apud FEUERWERKER, 2014, p. 92) foi um dos educadores que trabalhou intensamente no conceito de educação permanente destacando a importância de se pensar o processo educativo de uma forma diferenciada quando se trata de aprendizagem de adultos.

Qualquer processo educativo, dirigido a adultos, que se pretenda efetivo, deve ser desencadeado a partir da identificação de necessidades de aprendizagem por parte dos "educandos" e precisa dialogar com seus saberes prévios, tenham sido eles adquiridos sistematicamente por meio de processos educativos formais ou por meio de sua experiência cotidiana. (FEUERWERKER, 2014, p. 92 e 93)

Um marco importante na história do pensamento educacional da Organização das Nações Unidas para a Educação, a Ciência e a Cultura (Unesco) é o Relatório Faure, coordenado por Edgar Faure, na década de 1970, e orientado por quatro postulados:

[...] 1. A existência de uma comunidade internacional que, sob a diversidade de nações e de culturas, das opções políticas e dos níveis de desenvolvimento deve buscar solidariedade e a unidade de aspirações;

2. A crença numa democracia concebida como o direito de cada ser humano se realizar plenamente e de participar na edificação de seu próprio futuro;

3. O desenvolvimento que deve ter por objetivo a expansão integral das pessoas em toda a riqueza e a complexidade de suas expressões e compromissos;

4. Uma educação formadora das pessoas, cujo advento se torna mais necessário à medida que coações sempre mais duras separam em fragmentos cada ser. Trata-se então de não mais adquirir, de maneira exata, conhecimentos definitivos, mas de preparar para elaborar ao longo de toda a vida, um saber em constante evolução e de aprender a ser. (FAURE, 1974, p. 10, apud UNESCO, 2000, p. 13 e 14)

Destaca-se que um dos eixos norteadores do Relatório Faure consiste na educação permanente. Nesse sentido, diz o Relatório:

A partir de agora, a educação não se define mais em relação a um conteúdo determinado que se trata de assimilar, mas concebe-se, na verdade, como 


\begin{abstract}
um processo de ser que, através da diversidade de suas experiências, aprende a exprimir-se, a comunicar, a interrogar o mundo e a tornar-se sempre mais ele próprio. A ideia de que o homem é um ser inacabado e não pode realizar-se senão ao preço de uma aprendizagem constante, tem sólidos fundamentos não só na economia e na sociologia, mas também na evidência trazida pela investigação psicológica. Sendo assim, a educação tem lugar em todas as idades da vida e na multiplicidade das situações e das circunstâncias da existência. Retoma a verdadeira natureza que é ser global e permanente, e ultrapassa os limites das instituições, dos programas e dos métodos que the impuseram ao longo dos séculos. (FAURE, 1974, p. 225)
\end{abstract}

Seguindo nessa linha de reflexão sobre a política educacional e suas implicações, formou-se, no âmbito da Unesco, a Comissão Internacional sobre Educação para o século XXI, com o objetivo de fazer um balanço das tendências educacionais diante do acelerado processo de globalização (WERTHEIN, 2000). relatório dessa Comissão para a Unesco apresenta uma concepção de educação que supera a distinção tradicional entre educação inicial e Educação Permanente: a educação ao longo da vida. Segundo o referido documento, o conceito de Educação Permanente deve ser reconsiderado e ampliado, levando-se em conta as necessárias adaptações relacionadas às mudanças na vida profissional e deve ser uma construção contínua do indivíduo. "Ela deve permitir que cada um venha a tomar consciência de si próprio e de seu meio ambiente, sem deixar de desempenhar sua função na atividade profissional e nas estruturas sociais." (UNESCO, 1996, p. 12).

Ainda, conforme o relatório da Comissão Internacional sobre Educação para - Século XXI, a chamada educação ao longo da vida está ancorada em quatro pilares: aprender a conhecer, aprender a fazer, aprender a conviver e aprender a ser. Aprender a conhecer consiste no lema "aprender a aprender", de forma que os indivíduos se beneficiem das oportunidades oferecidas pela educação ao longo da vida. Aprender a fazer não se restringe à qualificação para o trabalho, mas compreende a competência do indivíduo em estar apto a enfrentar as diversas situações e a trabalhar em equipe. Aprender a conviver considera a compreensão mútua e a capacidade de gerenciar conflitos. Por fim, aprender a ser pressupõe que a educação deve levar em consideração todas as potencialidades do indivíduo, tais como a memória, o raciocínio, o sentido estético, as capacidades físicas, e a aptidão para comunicar-se (UNESCO, 1996). 
Nessa perspectiva, temos, no campo da ergologia, ${ }^{4}$ a utilização de termos como saberes constituídos e saberes investidos para executar as atividades no mundo do trabalho. O saber investido ou saber pessoal é resultado da história individual de cada um, de suas vivências e experiências, sejam profissionais, sejam de outros aspectos da vida. Esse saber é complementar ao saber constituído. O saber constituído consiste no saber acadêmico, ou seja, tudo o que é formalizado nos ensinos, nos livros, nos softwares, nas normas técnicas, organizacionais, econômicas, nos programas de ensino.

[...] este tipo de saber, por mais importante e primordial que seja, não é capaz de sozinho explicar o que acontece no trabalho tal como ele é exercido na situação real. Ele apenas é suficiente para explicar o trabalho tal como é prescrito, antes de sua realização, mas não para explicá-lo em sua realização efetiva. (TRINQUET, 2010, p. 100 e 101)

Aí é que entra o outro saber: o investido. Este saber, na visão de Trinquet (2010), diminui a distância entre o trabalho prescrito e o trabalho real, pois ele leva em consideração as experiências dos indivíduos adquiridas na vida pessoal e profissional.

Para o mundo do trabalho, ambos os saberes são indispensáveis.

Eles constituem os dois lados de toda a atividade de trabalho, sua unidade dialética. Para compreender e analisar uma situação de trabalho, o procedimento de associar os saberes acadêmicos com os saberes da experiência daqueles que trabalham, certamente, consiste em uma atitude deontológica e ética, mas, se trata, sobretudo, de uma postura científica. (TRINQUET, 2010, p. 100)

O educador Paulo Freire (1996) trata a educação de forma que esta deve levar em consideração a realidade dos indivíduos. Entre alguns dos questionamentos propostos por Freire, destaca-se, nesse ponto, a indagação sobre o porquê de não se estabelecer uma "intimidade" entre os saberes curriculares fundamentais aos alunos e a experiência social que eles têm como indivíduos (FREIRE, 1996, p. 34).

Trazendo a reflexão para o trabalho no campo da saúde, este tem uma característica singular: ser um trabalho coletivo. Essa concepção de trabalho coletivo

\footnotetext{
4 “[...] ergologia é um método de investigação pluridisciplinar em função de a atividade humana ser muito complexa para se compreender e analisar a partir de uma única disciplina, qualquer que seja ela. Todas são necessárias, embora nenhuma seja suficiente. Trata-se, portanto, de colocar em dialética - e não somente de sobrepô-las umas sobre as outras - o conjunto dos saberes elaborados pelas outras disciplinas. E quando se faz isso, não somente se tem uma visão mais realista e completa da situação real da atividade de trabalho humano, mas se descobre uma outra dimensão [...]". (TRINQUET, 2010, p. 94)
} 
relaciona-se com o trabalho sob o gerenciamento médico, uma vez que estes “apropriaram-se ao longo da história do saber em saúde como 'saber médico'”. (SCHERER apud JOAZEIRO; SCHERER, 2012, p. 283). Segundo Schwartz apud Joazeiro e Scherer (2012, p. 288), a educação:

[...] é, fundamentalmente relação entre pessoas marcada por um patrimônio de saberes que preexiste, e como saber conceitual, enfrenta o desconforto de ser insuficiente para lidar com as múltiplas nuanças deste campo marcado por uma grande complexidade e variabilidade.

Nesse sentido, na década de 1980, a Organização Pan-Americana de Saúde (Opas) propôs uma profunda transformação na teoria e na prática da educação do pessoal de saúde, a fim de induzir a reflexão sobre o contexto do trabalho, a partir da análise dos problemas encontrados no cotidiano dos serviços de saúde. $\mathrm{Na}$ época, partiu-se da evidência de que as capacitações tradicionais tinham baixo impacto, produzindo poucas mudanças nas práticas dos trabalhadores da área da saúde.

Assim, como já citado no capítulo que trata do contexto deste estudo, foi proposta no âmbito do Ministério da Saúde, como principal estratégia para formação e desenvolvimento dos trabalhadores do setor saúde, trabalhar a Educação Permanente em Saúde (EPS), de modo a transformar as práticas de formação, atenção, gestão e formulação de políticas, participação popular e controle social.

Para além de ser considerada uma prática de ensino aprendizagem, a EPS é uma política de educação em saúde. Trata-se, como já dito, de uma estratégia que parte dos problemas enfrentados na realidade e leva em consideração os conhecimentos e experiências das pessoas para tentar solucioná-los.

Ao aprofundarmos na temática de formação e desenvolvimento dos profissionais do setor saúde, é imprescindível trazer à tona as concepções acerca da EPS. Ceccim (2005) destaca que a EPS consiste no:

[...] processo educativo que coloca o cotidiano do trabalho - ou da formação - em saúde em análise, que se permeabiliza pelas relações concretas que operam realidades e que possibilita construir espaços coletivos para a reflexão e avaliação de sentido dos atos produzidos no cotidiano. [...] A Educação Permanente em Saúde, ao mesmo tempo em que disputa pela atualização cotidiana das práticas segundo os mais recentes aportes teóricos, metodológicos, científicos e tecnológicos disponíveis, insere-se em uma necessária construção de relações e processos que vão do interior das equipes em atuação conjunta, - implicando seus agentes -, às práticas organizacionais, - implicando a instituição e/ou o setor da saúde -, e às práticas interinstitucionais e/ou intersetoriais, - implicando as políticas nas quais se inscrevem os atos de saúde. (CECCIM, 2005, s/p) 
A educação permanente em saúde traz uma concepção de educação contrária ao processo de "[...] ensino-aprendizagem mecânico, quando os conhecimentos são considerados em si, sem a necessária conexão com o cotidiano, e os alunos se tornam meros escutadores e absorvedores do conhecimento do outro" (CECCIM; FERLA, 2008, p. 163).

\begin{abstract}
A escolha pela 'educação permanente em saúde' é a escolha por novas maneiras de realizar atividades, com maior resolutividade, maior aceitação e muito maior compartilhamento entre os coletivos de trabalho, querendo a implicação profunda com os usuários dos sistemas de saúde, com os coletivos de formulação e implementação do trabalho, e um processo de desenvolvimento setorial por 'encontro' com a população. (CECCIM; FERLA, 2008, p. 165)
\end{abstract}

Nessa perspectiva de superação do modelo de ensino-aprendizagem mecânico e investimento no compartilhamento entre os coletivos, Freire (1996) nos convida a pensar sobre termos que muitas vezes utilizamos no que se refere à educação, como "transferir conhecimento". Segundo o educador, "ensinar não é transferir conhecimento, mas criar as possibilidades para a sua própria produção ou a sua construção" (FREIRE, 1996, p. 52). Para ele, a educação deve ser vista como instrumento de libertação e esperança.

Para tanto, deve haver uma aposta na metodologia da problematização como elemento que favorece a reflexão e o diálogo entre educadores e educandos. A educação que só reproduz o que vivemos é chamada de educação "bancária", na qual quem sabe mais ensina quem sabe menos, preenchendo as chamadas lacunas de conhecimento.

Refletindo, ainda, acerca da metodologia da problematização, Johann (2009, p. 29) destaca:

\begin{abstract}
A problematização [...] instigará a atitude de busca incessante e de partilha de descobertas enriquecedoras. A atitude entre ambos, educadoreducando, será sempre marcada por uma relação de respeito e acolhimento do outro. Ambos partirão de suas leituras e de suas linguagens. Serão diferentes. Porém, ambas serão cultas, cada uma de seu jeito. O senso comum e a simplicidade de um e o academicismo de outro não os farão superiores um ao outro. A troca fará com que ambos cresçam e se eduquem mutuamente.
\end{abstract}

Freire (1987) faz a distinção entre dois tipos de educadores: o "educador bancário" e o "educador-educando". Para ele, o educador bancário segue a linha da antidialogicidade, enquanto o educador-educando se caracteriza por seu perfil dialógico, problematizador. A educação, segundo o autor, se faz nessa relação entre 
educadores e educandos mediatizados pelo mundo. Sobre a necessidade de se investir no diálogo para transformar o mundo, Freire (1987, p. 78-79) destaca: "Não é no silêncio que os homens se fazem, mas na palavra, no trabalho, na ação-reflexão". E completa: "[...] o diálogo é uma exigência existencial.”.

Para Johann (2009), a educação se constitui em preparação para a realização profissional e o que diferencia os seres humanos dos demais seres existentes é a sua racionalidade. Assim, um técnico preparado para uma atividade específica não poderá esconder o ser humano que a realizará. Isso implica os valores éticos de que se constituirá toda prática educativa.

O filósofo e pedagogo Dermeval Saviani (1994, p. 21-22) nos traz o conceito de educação relacionado com o trabalho e fala sobre a necessidade dos seres humanos nessa relação:

[...] a compreensão da natureza da educação passa pela compreensão da natureza humana. [...] o homem necessita produzir continuamente sua própria existência. [...] ele tem que adaptar a natureza a si, isto é, transformá-la. E isto é feito pelo trabalho. Portanto, o que difere o homem dos outros animais é o trabalho. E o trabalho se instaura a partir do momento em que seu agente antecipa mentalmente a finalidade da ação. Consequentemente, o trabalho não é qualquer tipo de atividade, mas uma ação adequada a finalidades. É, pois, uma ação intencional. [...] dizer, pois, que a educação é um fenômeno próprio dos seres humanos significa afirmar que ela é, ao mesmo tempo, uma exigência do e para o processo de trabalho, bem como é, ela própria, um processo de trabalho.

Saviani (1994) considera duas tendências acerca das diferentes concepções de educação, sendo a primeira composta por concepções pedagógicas que priorizam a teoria sobre a prática, ou seja, a pedagogia tradicional, centrada nas "teorias do ensino", tendo como norte a questão "como ensinar", dominada pela figura do professor focado na transmissão de conhecimentos acumulados por si. A segunda tendência, conforme o autor, compõe-se das concepções que subordinam a teoria à prática, o que representa diferentes modalidades da chamada pedagogia nova, centrada nas "teorias da aprendizagem", norteada pela questão "como aprender", o que segundo Saviani, levou à generalização do lema "aprender a aprender", que se constitui como um dos pilares da chamada "educação ao longo da vida" apresentados no relatório para a Unesco da Comissão Internacional sobre Educação para o século XXI.

Saviani (1994) faz, ainda, uma distinção entre o trabalho material e o trabalho não material. O trabalho material, para o autor, está relacionado às "exigências da vida que precisam ser satisfeitas em primeiro lugar, ou seja, da própria 
sobrevivência. Depois é que se apresentam e se impõem as necessidades do saber". Para o autor, a educação se encaixa no chamado "trabalho não material" e não se separa do conceito de ética:

Podemos, pois, dizer que a natureza humana não é dada ao homem, mas é
por ele produzida sobre a base da natureza bio-física. Consequentemente,
o trabalho educativo é o ato de produzir, direta e intencionalmente, em cada
indivíduo singular, a humanidade que é produzida histórica e coletivamente
pelo conjunto dos homens. (SAVIANI, 1994, p. 24)

Sobre a possibilidade de tornar a experiência uma maneira de formar as pessoas, Schwartz (2010) faz essa provocação e retoma os conceitos sob a ótica de filósofos como Marx e Hegel que tratam a afirmação de que a experiência é formadora algo redundante. Para o autor:

Quando frequentamos as situações de atividade e, notadamente, a atividade de trabalho, acredito que podemos dizer que toda situação de trabalho é, sempre em parte, e esse em parte é sempre imprevisível (quer dizer que não podemos jamais antecipar a proporção), aplicação de um protocolo e experiência ou encontro de encontros. (SCHWARTZ, 2010, p. 42)

Esse conceito apresentado por Schwartz (2010) vai ao encontro do que é apresentado na Política Nacional de Educação Permanente em Saúde (Pneps), ao valorizar a aprendizagem no trabalho e os saberes e experiências que as pessoas já carregam em si. Schwartz (2010) destaca também que em toda situação de trabalho há a aplicação de normas antecedentes. O autor fala sobre a distinção entre experiência do trabalho e o trabalho como experiência. $O$ fato de estar muito tempo na execução de uma determinada atividade não necessariamente pode ser algo positivo. Essa situação somente será positiva se houver a administração do trabalho como experiência, levando-se em consideração a administração do aspecto protocolar, do aspecto de normas antecedentes e do aspecto de encontro de encontros.

Retomando a discussão sobre a EPS, Ceccim (2005) a apresenta como uma estratégia que pode estar relacionada a diferentes concepções de educação. Ela pode estar associada à Educação em Serviço, quando estiver centrada nos conteúdos, instrumentos e recursos para a formação técnica. Pode também estar associada à Educação Continuada, quando pertencer à construção objetiva de quadros institucionais e à investidura de carreiras por serviço em tempo e lugar específicos. Pode, ainda, estar associada à Educação Formal de Profissionais, quando contemplar as multiplicidades da realidade de vivências profissionais. 
Ceccim (2005) também traz a relação de EPS com a Educação Popular ou Educação de Jovens e Adultos, considerando conceitos trazidos pelo educador Paulo Freire. No caso da proximidade entre os conceitos de educação permanente em saúde e de educação popular em saúde, a distinção se dá pelo foco da primeira, que está no trabalho, e o foco da segunda, que está na cidadania.

Já o sanitarista Campos (2006) traz outra concepção de educação, que é o método Paideia. Esse método consiste na "[...] educação de pessoas objetivando a ampliação de sua capacidade de analisar e de intervir sobre o mundo" (CAMPOS, 2006, p. 20). O autor fala da dependência de espaços de cogestão, ou seja, compartilhamento de poder, para a efetivação do método Paideia. Segundo o sanitarista, o método Paideia busca apoiar e avaliar o desenvolvimento de pessoas e de instituições a partir de três critérios:

[...] 1) Reconhecer que uma das finalidades principais da política, da gestão e do trabalho humano é a construção de bem-estar e justiça social.

[...] 2) A política, a gestão e o trabalho deveriam ser julgados também por sua capacidade de construir os maiores coeficientes possíveis de autonomia e de liberdade para as pessoas e instituições.

[...] 3) Assegurar a resolução de conflitos e a elaboração de contratos entre interesses e valores diferentes sem o uso da violência, mas graças ao uso de instrumentos de convencimento e de negociação. (CAMPOS, 2006, p. 26 e 27)

Trazendo novamente a discussão apresentada na introdução desta dissertação, um dos grandes desafios, na gestão federal do Sistema Único de Saúde (SUS), consiste em superar o pensamento de que problemas de gestão como: i) a baixa capacidade gerencial; ii) a ausência de pessoal qualificado; iii) o desconhecimento sobre os princípios e as normas operacionais do SUS; iv) a falta de conhecimento de gestores e trabalhadores sobre as bases técnicas e políticas do SUS e pouca oferta de qualificação na área de Saúde Pública e Gestão de Serviços de Saúde - podem ser facilmente solucionados com cursos prontos. (CONASS, 2011). Sobre esse pensamento de gestores de saúde que se sustentam em ações de educação para solucionar todos os seus problemas de gestão, Merhy (2005, s/p), destaca que:

Não é possível sustentarmos mais as quase exclusivas visões gerenciais que se posicionam sistematicamente pela noção de que a baixa eficácia das ações de saúde é devida à falta de competência dos trabalhadores e que pode ser corrigida à medida que suprimos, por cursos compensatórios, aquilo que Ihes falta. 
E sob um ponto de vista mais estratégico, Merhy et al. (2006, s/p) afirmam que a EP é, para a Opas, "[...] uma estratégia para construção de processos mais eficazes para o desenvolvimento do pessoal de saúde, que parte da realidade e são mais participativos." Os autores afirmam, ainda, que a EP pressupõe uma reflexão sobre as práticas vigentes e deve produzir desconforto. Esse desconforto deve se dar pela percepção de que a forma de fazer ou de pensar é insuficiente ou insatisfatória para superar os desafios do trabalho. E esse ato de reflexão sobre a prática é que deve produzir alternativas para transformá-las.

Nesse sentido, Freire (1996) destaca o pressuposto do ensinar que é a exigência da reflexão crítica sobre a prática. Essa é mais uma convergência com os pensadores do tema EPS. Freire (1996, p. 43-44) afirma que "é pensando criticamente a prática de hoje ou de ontem que se pode melhorar a próxima prática".

Para ter mais efetividade nas ações empreendidas no campo da saúde, é preciso fazer sentido para os atores envolvidos. Isto é o que Merhy chama de "aprendizagem significativa". 5 Sobre esse termo Merhy et al. (2006, s/p) destacam:

Uma informação ou experiência pedagógica somente produz sentido quando dialoga com todo o acúmulo anterior que as pessoas trazem consigo. Partir dos desconfortos, dialogar com os acúmulos e produzir sentido, são as chaves para a aprendizagem significativa.

$\mathrm{Na}$ discussão sobre a formação e o desenvolvimento dos profissionais de saúde, é preciso considerar também a concepção de educação continuada. Merhy et al. (2006) apresentam um quadro diferenciando as concepções de educação continuada e educação permanente. No entanto, essa diferenciação dicotomiza essas duas vertentes, apresentando a educação permanente como algo positivo e a educação continuada como algo negativo, tornando o quadro de Merhy et. al (2006) questionável e sujeito a críticas. Além disso, foi possível constatar que elementos trazidos como características dos processos de Educação Permanente podem ser encontradas também nos processos de Educação Continuada.

\footnotetext{
${ }^{5}$ Esse conceito é apresentado na Portaria GM no 278, de 27 de fevereiro de 2014, que "[...] institui diretrizes para implementação da Política de Educação Permanente em Saúde, no âmbito do Ministério da Saúde. [...] aprendizagem significativa: processo de aprendizagem que propicia a construção de conhecimentos a partir dos saberes prévios dos sujeitos articulados aos problemas vivenciados no trabalho." (BRASIL, 2014, s/p)
} 
Quadro 1 - Comparativo entre educação continuada e educação permanente

Referência Analítica Pressuposto pedagógico
Educação Continuada

$O$ conhecimento define as práticas. A aprendizagem é proposta como transmissão de conteúdos, centrada no conhecimento.
Educação Permanente

As práticas são definidas por múltiplos fatores

(conhecimentos, valores, relações de poder, organização do trabalho, etc.) A aprendizagem requer que se trabalhe com elementos que façam sentido para os atores envolvidos (aprendizagem significativa), assim como que possibilite criar novos sentidos (criar e recriar relações), centrada nas relações. Transformação das práticas.

Atualização de conhecimentos específicos.

\begin{tabular}{|l|}
\hline Objetivo principal \\
\hline Público \\
\hline $\begin{array}{l}\text { Planificação/ Programação } \\
\text { Educativa }\end{array}$
\end{tabular}

Profissionais específicos, de acordo com os conhecimentos a trabalhar.

Descendente. A partir de uma leitura geral dos problemas, identificam-se temas e conteúdos para trabalhar com os profissionais, geralmente sob a forma de cursos.

Equipes de atenção e/ou de gestão em qualquer esfera do sistema: docentes, estudantes e usuários.

Ascendente. A partir de análises coletivas dos processos de trabalho, identificam-se os nós críticos (de natureza diversa) a serem enfrentados na atenção e/ou na gestão, na formação e na educação popular. Possibilita a construção de estratégias contextualizadas que promovam o diálogo entre as políticas gerais e a singularidade de lugares e pessoas.

Cursos padronizados: carga horária, conteúdo e dinâmicas definidas centralmente. As atividades educativas são construídas de modo desarticulado em relação à gestão, à organização do sistema e ao controle social.

A atividade educativa é pontual, fragmentada e se esgota em si mesma.
Repercussões educativas
Acumulação cognitiva, bolsa de estudos, racionalidade instrumental na condução de processos e métodos.
Muitos problemas são

resolvidos/ situações enfrentadas.

Quando necessárias, as atividades educativas são construídas de modo ascendente, levando em conta as necessidades específicas de profissionais e equipes. As atividades educativas são construídas de modo articulado com medidas para a reorganização do sistema (atenção - gestão - formação controle social articulados) que implicam acompanhamento e apoio técnico.

Constituição de equipes para apoio técnico em temas específicos prioritários; instituição de processos de assessoramento técnico para formulação de políticas específicas; desenvolvimento de habilidades assistenciais; desenvolvimento de capacidades pedagógicas; racionalidade 
continuação

Referência Analítica Educação Continuada Educação Permanente condução de processos e métodos.

Fonte: Merhy et. al (2006, s/p)

Marandola et al. (2009, p. 58) também fazem a distinção entre os conceitos de educação continuada, educação em saúde e educação permanente:

[...] educação continuada visa qualificação profissional através das capacitações técnico-científicas; educação em saúde busca a valorização dos saberes populares e a corresponsabilidade do sujeito para com sua saúde; enquanto que a educação permanente enfoca a transformação das práticas no momento em que elas acontecem, por meio da problematização, da aprendizagem significativa e da articulação entre os atores envolvidos no quadrilátero serviço/gestão/academia/controle social.

As referidas autoras destacam que esses não são conceitos antagônicos, apesar de apresentarem objetivos diferentes. No entanto, a Educação Permanente deve ser considerada como "estruturante das eventuais necessidades de atualizações técnicas".

Ceccim (2005, s/p), no entanto, faz a crítica sobre os processos de Educação Continuada:

\begin{abstract}
As capacitações não se mostram eficazes para possibilitar a incorporação de novos conceitos e princípios às práticas estabelecidas - tanto de gestão, como de atenção e de controle social - por trabalharem de maneira descontextualizada e se basearem principalmente na transmissão de conhecimentos. A Educação Permanente em Saúde pode ser orientadora das iniciativas de desenvolvimento dos profissionais e das estratégias de transformação das práticas de saúde.
\end{abstract}

Davini (2009) também questiona os resultados dos processos de capacitação, que, por mais que se alcancem aprendizagens individuais, nem sempre são traduzidos em aprendizagem organizacional, ou seja, não se transferem para a ação coletiva. E ainda complementa afirmando que a Educação Continuada, ou a capacitação tradicional, representa a continuidade do modelo escolar ou acadêmico baseado na transmissão de conhecimentos.

A persistência dos modelos escolares obedece não somente ao fator cultural ou aos "modelos mentais", mas a uma visão muito restrita dos conceitos de aprendizagem e da aprendizagem do adulto nas organizações [...]. (DAVINI, 2009, p. 45)

Por outro lado, Campos (2006) faz algumas análises em relação aos processos de educação permanente em saúde. A ideia de que o processo de formação dos profissionais não ocorre apenas em sala de aula, mas também nos 
espaços de trabalho é, para o autor, muito interessante. No entanto, quando se pensa somente na EPS, há uma tendência em desvalorizar os espaços formais de conhecimento e hiper valorizar o saber não formalizado.

Não dá para apoiar-se uma política de pessoal para o SUS somente na
educação no trabalho; cursos para essas pessoas, cursos de longa duração
e de formação são também necessários. [...] Acho que há um desafio:
temos que combinar a educação no trabalho, discussão de casos, estudos
temáticos, com a formação mais estruturada. (CAMPOS, 2006, p. 54)

No caso da EPS, segundo Ceccim (2005, s/p), o que é central "[...] é a sua porosidade à realidade mutável e mutante das ações e dos serviços, é sua ligação política com a formação de profissionais e de serviços"; é também sua aposta nas construções coletivas de respostas e desafios.

Importante destacar que esta pesquisa não tem como objetivo desqualificar os cursos formais, ou a Educação Continuada, como se apresentam as informações no Quadro 1, por exemplo. A intenção aqui é trazer diferentes visões sobre concepções de educação, de forma a trabalhar questões referentes à formação e ao desenvolvimento dos trabalhadores da gestão federal do SUS.

A concepção de Educação Permanente também se aproxima à definição de educação não formal apresentada por Gadotti (2005). Diferentemente da educação formal, a educação não formal é menos burocratizada e não há a necessidade de seguir um caminho para a progressão. Além disso, a educação não formal não requer a concessão de um certificado e se caracteriza por ser flexível tanto em relação ao tempo quanto em relação ao espaço. Assim, é possível classificar o trabalho como ambiente de aprendizado, corroborando o pensamento de Merhy et. al (2006), segundo os quais o trabalho funciona como uma escola.

Ainda sobre as diferentes concepções de educação, Franco (2007, p. 429) ressalta o "não reconhecimento do conhecimento gerado com base nas vivências cotidianas na atividade de trabalho". No entanto, valoriza-se a Educação Continuada, que, de acordo com o autor, propõe a continuidade da "transferência de conhecimento" de forma a suprir uma formação deficitária. A essa ação Franco denominou "pedagogia da dependência" (FRANCO, 2007, p. 429).

Novamente aqui se faz uma crítica acerca dos processos de Educação Continuada. Ressalta-se que este não é o pensamento da pesquisadora, que acredita que tanto a Educação Continuada como a Educação Permanente devem 
ser trabalhadas como estratégias complementares no campo da formação em saúde.

Buscando uma nova exigência de formação, Ceccim e Ferla (2009, s/p) afirmam que é preciso "[...] buscar a potência, levantando questões, investigando realidades e interrogando paisagens, na perspectiva de uma aprendizagem de si, dos entornos e dos papéis profissionais (potências profissionais)". É o que os autores chamam de educação problematizadora.

A partir desses pensamentos, Ceccim e Ferla (2009, p. 453) propõem que se pense a "[...] Educação Permanente em Saúde como processo de formação, acionador de movimentos de estranhamento, de desacomodação, de 'perguntação' e de implicação, potência para um coletivo diferir de si mesmo e de dobrar novas práticas". Para os autores, a educação se compõe não somente de uma estrutura didático-pedagógica, mas também pelas "[...] relações de aprendizagem (processos cognitivos, processos afetivos, processos sociais)".

Por fim, cabe destacar o que trazem Ceccim e Ferla (2008, p. 166) no que se refere à diferenciação entre a concepção de EPS e outras concepções de educação:

Se uma informação nos impede de continuarmos a ser o mesmo que éramos, nos impede de deixar tudo apenas como está e tensiona nossas implicações com os usuários de nossas ações, ela desencadeou "educação permanente em saúde".

Após toda a revisão de literatura e busca por diferentes concepções de educação, foi possível perceber que há muitas semelhanças em relação às concepções apresentadas por Freire (1996), Trinquet (2010), Schwartz (2010) e os pensadores da EPS, como Ceccim (2005) e Merhy et. al (2006).

Considerando todos os autores pesquisados e as diferentes concepções de educação apresentadas, foi construído o quadro a seguir como referência para a análise das narrativas contempladas na Coletânea e que são objeto desse estudo.

Quadro 2 - Relação entre autores/referências e concepções de educação

\begin{tabular}{|l|l|}
\hline \multicolumn{1}{|c|}{ AUTOR/ REFERÉNCIA } & \multicolumn{1}{c|}{ CONCEPÇÃO DE EDUCAÇÃO } \\
\hline SAVIANI (1994) & $\begin{array}{l}\text { Educação é "uma exigência do e para o processo } \\
\text { de trabalho, bem como é, ela própria, um processo } \\
\text { de trabalho." (SAVIANI, 1994, p. 21 e 22) } \\
\text { Educação como trabalho não material. }\end{array}$ \\
\hline CAMPOS (2006) & $\begin{array}{l}\text { Método Paideia: consiste na [...] educação de } \\
\text { pessoas objetivando a ampliação de sua } \\
\text { capacidade de analisar e de intervir sobre o mundo. } \\
\text { Para efetivação do Método é preciso haver espaços } \\
\text { de cogestão e de compartilhamento de poder. }\end{array}$ \\
\hline
\end{tabular}


continuação

AUTOR/ REFERÉNCIA

JOHANN (2009)

MARANDOLA et al. (2009)

MERHY et al. (2006)
CONCEPÇÃO DE EDUCAÇĀO

Educação se constitui em preparação para a realização profissional.

Educação continuada: qualificação profissional por meio das capacitações técnico-científicas.

Educação em saúde: valorização dos saberes populares e a corresponsabilidade do sujeito para com sua saúde.

EP: "estruturante das eventuais necessidades de atualizações técnicas".

EP: transformação das práticas no momento em que elas acontecem, por meio da problematização, da aprendizagem significativa e da articulação entre os atores envolvidos no quadrilátero serviço/gestão/academia/controle social.

O trabalho funciona como uma escola.

Os processos educativos se constroem a partir da realidade dos trabalhadores, de suas concepções e de suas relações de trabalho.

EP: estratégia para a construção de processos mais eficazes para o "desenvolvimento do pessoal de saúde", que parte da realidade concreta e são mais participativos.

Educação formal; e

Educação não formal: considera o ambiente de trabalho como ambiente de aprendizado.

POLÍTICA NACIONAL, DE EDUCAÇÃO Educação como aprendizagem no trabalho e PERMANENTE EM SAÚDE aprendizagem significativa.

Aprendizagem no trabalho, onde 0 aprender e o ensinar se incorporam ao quotidiano das organizações e ao trabalho.

$\operatorname{FREIRE}(1987 ; 1996)$

Educação deve levar em consideração a realidade dos indivíduos. Reflexão crítica sobre a prática. Instrumento de libertação e esperança. Metodologia da problematização. Educação se faz na relação entre educadores e educandos mediatizados pelo mundo.

TRINQUET (2010) Educar é compartilhar. Destaca-se, ainda, a importância de associar os saberes acadêmicos com os saberes da experiência para compreender e analisar uma situação de trabalho.

CECCIM (2005) Educação como orientadora de iniciativas de desenvolvimento dos profissionais e das estratégias de transformação das práticas de saúde.

EP associada à Educação Continuada: construção objetiva de quadros institucionais e investidura de carreiras por serviço em tempo e lugar específicos.

EP associada à Educação em Serviço: centrada nos conteúdos, instrumentos e recursos para a formação técnica.

EP associada aos conceitos de Educação Popular ou Educação de Jovens e Adultos, trazidos pelo educador Paulo Freire.

EP como processo educativo que coloca o cotidiano do trabalho - ou da formação - em saúde em análise.

CECCIM; FERLA (2009)
EPS como processo de formação, acionador de movimentos de estranhamento, de desacomodação, de "perguntação" e de implicação, 
continuação

\begin{tabular}{|c|c|}
\hline AUTOR/ REFERÉNCIA & CONCEPÇĀO DE EDUCAÇĀO \\
\hline & $\begin{array}{l}\text { potência para um coletivo diferir de si mesmo e de } \\
\text { dobrar novas práticas. }\end{array}$ \\
\hline SCHWARTZ (2010) & $\begin{array}{l}\text { [...] toda situação de trabalho é, sempre em parte, } \\
\text { aplicação de um protocolo e experiência ou } \\
\text { encontro de encontros. } \\
\text { Educação é [...] relação entre pessoas marcada por } \\
\text { um patrimônio de saberes que preexiste. }\end{array}$ \\
\hline UNESCO (1996) & $\begin{array}{l}\text { Educação ao longo da vida - construção contínua } \\
\text { do indivíduo e ancorada em quatro pilares: } \\
\text { aprender a conhecer, aprender a fazer, aprender a } \\
\text { conviver e aprender a ser. }\end{array}$ \\
\hline
\end{tabular}

Com as concepções de educação relacionadas no Quadro 2 e com as concepções de educação trazidas pelos autores das narrativas, conforme será detalhado nos resultados deste estudo, foi possível identificar os seguintes temas para análise das experiências de educação permanente publicadas na Coletânea da 1aㅡ Mostra Nacional:
a) análise do cotidiano do trabalho;
b) aprendizagem em serviço;
c) aprendizagem significativa;
d) compartilhamento de informações e saberes;
e) desenvolvimento pessoal e organizacional;
f) problematização;
g) reflexão sobre a prática;
h) trabalho como espaço de aprendizado;
i) transformação de práticas;
j) valorização e humanização dos profissionais; e
k) valorização de saberes prévios. 


\section{CAMINHO METODOLÓGICO}

Esta pesquisa caracteriza-se como pesquisa qualitativa, que, segundo Creswell (2010), é uma forma de investigação interpretativa na qual é possível ao investigador fazer uma interpretação daquilo que vê, ouve e entende. No entanto, conforme o autor, as interpretações do pesquisador não podem ser separadas de suas origens, história, contextos e entendimentos anteriores.

De acordo com Minayo (2010), a pesquisa qualitativa possibilita uma melhor compreensão dos valores culturais, das representações de determinados grupos sobre temas específicos e a relação entre atores sociais tanto nas instituições quanto nos movimentos sociais ao longo do processo histórico.

O universo da produção humana que pode ser resumido no mundo das relações, das representações e da intencionalidade e é objeto da pesquisa qualitativa dificilmente pode ser traduzido em números e indicadores quantitativos. (MINAYO, 2010, p. 21)

Trata-se de um estudo de caso com delineamento exploratório descritivo e recorte transversal, apresentando como objetivo principal analisar o processo de implementação da Educação Permanente em Saúde (EPS) na gestão federal do Sistema Único de Saúde (SUS) no contexto das experiências apresentadas na $1^{\text {a }}$ Mostra Nacional de Educação Permanente em Saúde.

Apesar do total de 165 experiências inscritas na Mostra, apenas cem autores enviaram suas narrativas para publicação na Coletânea de Narrativas: Experiências da I Mostra Nacional de Educação Permanente em Saúde - reconhecendo as práticas dos trabalhadores do Ministério da Saúde, sendo estas objeto deste estudo.

Das cem narrativas publicadas, oito eram narrativas de convidados de outras esferas, como Secretarias Estaduais e Municipais de Saúde, e também Universidades. Onze narrativas tratavam de impressões dos facilitadores das rodas de conversa ${ }^{6}$, nas quais os trabalhos da $1^{\text {a }}$ Mostra foram apresentados. Essas narrativas, que totalizam dezenove, foram excluídas por não trazerem as informações que são objeto deste estudo. Portanto, ficaram 81 narrativas para análise. Na sequência da análise, das 81 narrativas, 25 foram excluídas por não

\footnotetext{
6 "[...] espaços de diálogo onde foram apresentados relatos de experiências em Educação Permanente, com o objetivo de socializar saberes e promover a reflexão voltada para a ação." (Chamada no 01/2014 para inscrições de experiências em educação permanente)
} 
trazerem nenhuma concepção de educação e/ou se caracterizarem como apenas um relato de participação na Mostra. Ao final, como escolha da pesquisadora, foram objeto de estudo e análise 56 narrativas de experiências da gestão federal do SUS.

Inicialmente foi realizada uma revisão de literatura científica em base bibliográfica on-line, SciELO (Scientific Electronic Library Online). A partir dessa base, foi possível identificar 25 artigos utilizando como descritor o termo "educação permanente em saúde". Além dos artigos pesquisados no SciELO, foram analisados relatórios que tratam do tema educação, como relatórios de Faure e Delors da Organização das Nações Unidas para a Educação, a Ciência e a Cultura (Unesco).

Entre os principais documentos pesquisados, destacam-se:

a) toda a legislação referente à instituição da Política Nacional de Educação Permanente em Saúde (Pneps) e suas diretrizes;

b) relatórios da Unesco sobre a política educacional;

c) relatórios das Conferências Nacionais de Saúde, em especial a $8^{\text {a }}$ edição, realizada em 1986, e das Conferências Nacionais de Recursos Humanos em Saúde, realizadas em 1986 e 1993, além do documento base para a $3^{\underline{a}}$ Conferência Nacional de Gestão do Trabalho e da Educação na Saúde; e

d) publicações do Ministério da Saúde relacionadas ao tema.

Utilizou-se como metodologia a análise de conteúdo que Bardin (1977, p. 44) descreve como uma técnica que "[...] procura conhecer aquilo que está por trás das palavras sobre as quais se debruça". A autora ainda completa: "[...] a análise de conteúdo é uma busca de outras realidades através das mensagens.".

Após uma leitura flutuante das narrativas, a partir da qual, segundo Bardin (1979), "podem surgir intuições que convém (sic) formular em hipóteses", para coleta e delineamento do procedimento de análise das informações, optou-se pela construção de um quadro analítico (Apêndice A), com o objetivo de identificar e caracterizar as narrativas da seguinte forma: i) concepções de educação adotadas; ii) participantes; iii) ações desenvolvidas; iv) método utilizado para desenvolvimento das ações; v) objetivo(s) das ações; e, por fim, vi) os resultados ou mudanças identificadas nos processos de trabalho de unidades da gestão federal do SUS segundo as experiências apresentadas na $1^{\underline{a}}$ Mostra Nacional de Educação Permanente em Saúde.

A análise das narrativas foi guiada pelas seguintes questões norteadoras: 
a) quais as concepções de educação presentes nas narrativas?

b) de que maneira as diretrizes da Pneps se expressam nas experiências apresentadas?

c) quais mudanças podem ser identificadas nos processos de trabalho de unidades da gestão federal do SUS segundo as experiências apresentadas na $1^{\underline{a}}$ Mostra Nacional de Educação Permanente em Saúde?

Segundo Minayo (2008), existem várias modalidades de Análise de Conteúdo, dentre estas a Análise Temática, escolhida para este trabalho, por ser, de acordo com a autora, a modalidade "mais simples e considerada apropriada para as investigações qualitativas em saúde".

Definindo "tema", Bardin (1977, p. 105) traz como conceito: [...] a unidade de significação que se liberta naturalmente de um texto analisado segundo critérios relativos à teoria que serve de guia à leitura.

Para se fazer uma análise temática, de acordo com Minayo (2008), é preciso descobrir os núcleos de sentido que compõem uma comunicação, levando-se em consideração a presença ou frequência de temas. A autora ainda detalha três etapas da análise temática: i) pré-análise; ii) exploração do material; e iii) tratamento dos resultados obtidos e interpretação.

A pré-análise pressupõe uma revisita às hipóteses e ao objetivo da pesquisa e pode ser desdobrada em subetapas como: leitura flutuante; constituição do corpus; e formulação e reformulação de hipóteses e objetivos.

Neste trabalho, foi realizada a leitura flutuante das narrativas da 1a Mostra e também de artigos pesquisados no SciELO com o descritor "educação permanente em saúde". A constituição do corpus deve responder ao que Minayo (2008) chama de "algumas normas de validade qualitativa: exaustividade; representatividade; homogeneidade; e pertinência”. Quanto à formulação e reformulação de hipóteses e objetivos, são subetapas que consistem numa retomada do processo inicial exploratório no qual podem ser revistas as hipóteses e os objetivos, corrigindo-os ou até mesmo abrindo para novas indagações.

Na segunda etapa da pesquisa, que consiste na exploração do material, há a categorização a partir de expressões ou palavras significativas para o objeto deste estudo. Para isso, foi construído um quadro analítico (Apêndice A), conforme já mencionado. Por fim, na etapa de tratamento dos resultados obtidos e interpretação, 
são propostas as inferências e as interpretações, considerando-se o referencial teórico.

No quadro analítico (Apêndice A), as concepções de educação apresentadas foram retiradas exatamente da forma como foram colocadas nas narrativas publicadas. Numa primeira leitura, apenas 34 narrativas traziam a concepção de educação de forma clara e direta. No entanto, optou-se por também incluir as narrativas que, a partir de interpretações dos dados, traziam temas que também remetem a alguma concepção de educação, o que justifica a inclusão das 56 narrativas para análise.

Para análise das narrativas, procedeu-se da seguinte forma:

a) no caso da correlação entre as narrativas e as diretrizes da Pneps, partiuse de uma síntese com termos e palavras-chave de cada uma das diretrizes para identificar nos textos essa correlação a partir de interpretações da pesquisadora acerca das ideias constantes nos textos. Dessa forma, foram identificadas as seguintes categorias:

- valorização do trabalho e do trabalhador em saúde;

- realização de práticas educacionais em espaços coletivos de trabalho;

- promoção de aprendizagem significativa com uso de metodologias ativas e críticas;

- favorecimento de autonomia e corresponsabilização de sujeitos nos processos de trabalho;

- fortalecimento da gestão da educação permanente em saúde de forma compartilhada e participativa;

- contribuição para a mudança cultural e institucional direcionada à gestão compartilhada e ao aprimoramento do SUS;

- contribuição para o enfrentamento da fragmentação dos serviços e das ações de saúde; e

- valorização das multiplicas dimensões humanas nos processos de ensino-aprendizagem;

b) no caso da identificação e reconhecimento de concepções de educação, partiu-se do referencial teórico adotado neste estudo e do que cada narrativa trazia de concepção, declarada expressamente ou inferida pela pesquisadora a partir de trechos das narrativas, para possibilitar 0 agrupamento destas por temas/ categorias, conforme destacados a seguir: 
- análise do cotidiano do trabalho;

- aprendizagem em serviço;

- aprendizagem significativa;

- compartilhamento de informações e saberes;

- desenvolvimento pessoal e organizacional;

- problematização;

- reflexão sobre a prática;

- trabalho como espaço de aprendizado;

- transformação de práticas;

- valorização e humanização dos profissionais; e

- valorização de saberes prévios;

c) em relação às mudanças ocorridas nos processos de trabalho de unidades da gestão federal do SUS, adotou-se a mesma forma de categorização daquela utilizada no caso da identificação e reconhecimento das concepções de educação. Assim, foram definidos pela pesquisadora os seguintes temas/ categorias:

- qualificação de processos de trabalho (mudanças institucionais e transformações positivas no trabalho);

- integração entre equipes;

- aprendizagem no trabalho; e

- satisfação do usuário.

A partir dos procedimentos metodológicos descritos, foram encontrados os resultados detalhados e discutidos nos capítulos seguintes.

Destaca-se que o projeto de pesquisa referente a este estudo foi aprovado pelo Comitê de Ética em Pesquisa da Universidade de Brasília (Parecer no 1.317.085) e seguiu as normas da Resolução oํ 466/12 do Conselho Nacional de Saúde. (Anexo A)

Considerando que a pesquisa se restringiu à análise documental, a pesquisadora responsável solicitou dispensa do Termo de Consentimento Livre e Esclarecido (TCLE) ao Sistema CEP/CONEP. 


\section{RESULTADOS}

\subsection{Caracterização geral das experiências}

A Coletânea de Narrativas reuniu relatos de experiências apresentadas na $1^{\text {a }}$ Mostra Nacional de Educação Permanente em Saúde que traduziam trabalhos desenvolvidos na gestão federal do Sistema Único de Saúde (SUS), ou seja, na sede do Ministério da Saúde, em Brasília, e nas unidades do Ministério localizadas nos estados, sendo os Núcleos Estaduais, os Hospitais Federais do Rio de Janeiro, os Institutos Nacionais, os Distritos Sanitários Especiais Indígenas (Dsei), representados pela Secretaria Especial de Saúde Indígena, além de entidades vinculadas como Fundação Oswaldo Cruz (Fiocruz) e a Empresa Brasileira de Hemoderivados e Biotecnologia (Hemobrás).

Do total de 51 órgãos existentes na estrutura do Ministério da Saúde, incluindo unidades da administração direta e da indireta, 26 tiveram relatos publicados na Coletânea de Narrativas da Mostra, conforme quadro a seguir:

Quadro 3 - Total de órgãos existentes na estrutura do MS; órgãos do MS com narrativas publicadas na Coletânea; e Unidades da Federação/ Região que representam

\begin{tabular}{|c|c|c|}
\hline $\begin{array}{l}\text { Total de órgãos existentes na } \\
\text { estrutura do MS (Administração } \\
\text { direta e indireta) }\end{array}$ & $\begin{array}{l}\text { Órgãos do MS com narrativas } \\
\text { publicadas na Coletânea }\end{array}$ & $\begin{array}{c}\text { Unidades da Federação/ } \\
\text { Região }\end{array}$ \\
\hline 6 Hospitais Federais & 4 Hospitais Federais & $\begin{array}{l}\text { Rio de Janeiro/ Região } \\
\text { Sudeste }\end{array}$ \\
\hline 4 Institutos & 2 Institutos & $\begin{array}{l}\text { Rio de Janeiro e Pará/ } \\
\text { Regiões Sudeste e Norte }\end{array}$ \\
\hline 7 Secretarias & 6 Secretarias & $\begin{array}{l}\text { Distrito Federal/ Região } \\
\text { Centro-Oeste }\end{array}$ \\
\hline $\begin{array}{l}26 \text { Núcleos Estaduais do } \\
\text { Ministério da Saúde }\end{array}$ & $\begin{array}{l}12 \text { Núcleos Estaduais do } \\
\text { Ministério da Saúde }\end{array}$ & $\begin{array}{l}\text { SC, RS, PA, CE, PB, SP, } \\
\text { ES, MG, RJ, BA, TO, PR } \\
\text { (Regiões Sul, Norte, } \\
\text { Nordeste e Sudeste) }\end{array}$ \\
\hline $\begin{array}{l}8 \text { entidades da Administração } \\
\text { Indireta }\end{array}$ & $\begin{array}{l}2 \text { entidades da Administração } \\
\text { Indireta }\end{array}$ & $\begin{array}{l}\text { Distrito Federal/ Região } \\
\text { Centro-Oeste }\end{array}$ \\
\hline
\end{tabular}


Entre as principais ações desenvolvidas e destacadas nas 56 narrativas que foram objeto deste estudo, estão a realização de cursos formais nas modalidades presencial e a distância, oficinas, rodas de conversa, reuniões de equipe, encontros entre trabalhadores, grupos de trabalho e estratégias de aprendizagem em serviço.

Em relação ao perfil de participantes das ações relatadas nas narrativas de experiências da $1^{\text {a }}$ Mostra Nacional, destacam-se: i) trabalhadores de unidades específicas da gestão federal do SUS (ex.: equipes de enfermagem de Hospitais e equipes que atuam exclusivamente em determinadas unidades do Ministério da Saúde); ii) trabalhadores do Ministério da Saúde e equipes multidisciplinares de saúde indígena; iii) representantes de diferentes esferas de gestão do SUS; iv) e profissionais e conselheiros de saúde.

Foram identificadas experiências com diferentes concepções de educação, conforme será apresentado mais à frente. Essa diferença de tipos de narrativas se deu em razão da forma como foi solicitada a apresentação do texto. Conforme descrito na Coletânea, após a realização da Mostra, foi solicitado aos participantes o envio de um texto de apenas uma lauda, com a descrição das experiências apresentadas e as percepções de cada um no compartilhamento dessas durante a realização do evento. Assim, os autores tiveram a liberdade de expor, à sua maneira, como foi a experiência de participar da Mostra e também apresentar o relato desenvolvido sobre seu processo de trabalho (BRASIL, 2015, p.16).

\subsection{Como as ações realizadas na gestão federal do SUS se correlacionam com as diretrizes da Política Nacional de Educação Permanente em Saúde?}

Para identificar de que maneira as diretrizes da Pneps se expressam nas experiências apresentadas nas narrativas, foi realizada uma análise das ações, dos métodos utilizados para desenvolvimento das ações e seus respectivos objetivos. Cabe ressaltar que, na análise das narrativas, foi considerado como método para desenvolvimento das ações os procedimentos adotados e relatados nas narrativas.

Inicialmente, foi elaborada uma síntese com a relação das ações/atividades desenvolvidas e as diretrizes da Pneps. Tomou-se por base a definição de ações de educação trazida pela referida Política. De acordo com a Pneps, são consideradas ações de educação: reflexão e aprendizagem no/para o trabalho, no âmbito das 
equipes multiprofissionais, cursos presenciais e a distância, aprendizagem em serviço, grupos formais de estudos, intercâmbios ou estágios, oficinas, seminários, congressos e outras, que contribuam para a pactuação dos processos de trabalho, formação, atualização, qualificação profissional e desenvolvimento dos trabalhadores, em consonância com as diretrizes institucionais do Ministério da Saúde.

Dessa forma, a partir de uma análise mais aprofundada das ações realizadas, bem como tomando por base o método adotado para desenvolvimento das ações em cada uma das experiências relatadas e os objetivos das ações realizadas, foi possível identificar a quais diretrizes estavam relacionadas, com exceção da diretriz que trata da articulação entre Educação Permanente em Saúde (EPS) e a gestão de pessoas por competências, o que pode ser constatado na tabela a seguir, na qual está destacado o quantitativo de narrativas relacionadas a cada uma das diretrizes da Pneps.

Tabela 1 - Quantitativo de narrativas segundo as diretrizes da Pneps

\begin{tabular}{l|c}
\hline \multicolumn{1}{c|}{ DIRETRIZES } & TOTAL \\
\hline $\begin{array}{l}\text { I. Valorização do trabalhador e do trabalho em saúde } \\
\text { II. Realização de práticas educacionais em espaços coletivos de trabalho }\end{array}$ & 3 \\
$\begin{array}{l}\text { III. Promoção de aprendizagem significativa com uso de metodologias ativas e } \\
\text { críticas }\end{array}$ & 3 \\
$\begin{array}{l}\text { IV. Favorecimento de autonomia e corresponsabilização de sujeitos nos processos de } \\
\text { trabalho }\end{array}$ & 4 \\
$\begin{array}{l}\text { V. Articulação entre a EPS e a gestão de pessoas por competências para a a } \\
\text { organização das ações de educação no MS }\end{array}$ & 0 \\
$\begin{array}{l}\text { VI. Fortalecimento da gestão da educação permanente em saúde de forma } \\
\text { compartilhada e participativa }\end{array}$ & 1 \\
$\begin{array}{l}\text { VII. Contribuição para a mudança cultural e institucional direcionada à gestão } \\
\text { compartilhada e ao aprimoramento do SUS } \\
\text { VIII. Contribuição para o enfrentamento da fragmentação dos serviços e das } \\
\text { ações de saúde } \\
\begin{array}{l}\text { IX. Valorização das múltiplas dimensões humanas nos processos de ensino- } \\
\text { aprendizagem }\end{array}\end{array}$ \\
\begin{tabular}{l} 
Não foi possível identificar \\
\hline
\end{tabular}
\end{tabular}

Pela Tabela 1, é possível afirmar que há, nas narrativas analisadas, uma prevalência maior da diretriz que trata da "Realização de práticas educacionais em 
espaços coletivos de trabalho". Essa diretriz aparece em quinze narrativas. No Quadro 4, destacam-se três narrativas que se relacionam a essa diretriz. Essas três narrativas foram escolhidas pela pesquisadora por apresentarem informações em todos os campos necessários para análise.

Quadro 4 - Correlação entre ações, métodos, objetivos e a diretriz da Pneps correspondente (Realização de práticas educacionais em espaços coletivos de trabalho)

\begin{tabular}{|c|c|c|c|c|}
\hline Narrativas & Ações & Método & $\begin{array}{c}\text { Objetivo(s) das } \\
\text { acões }\end{array}$ & Diretriz \\
\hline $\begin{array}{l}\text { "A Educação } \\
\text { Permanente em } \\
\text { Saúde como } \\
\text { ferramenta de } \\
\text { trabalho na clínica } \\
\text { de neurocirurgia" }\end{array}$ & $\begin{array}{l}\text { Rodas de } \\
\text { conversa } \\
\text { mensais } \\
\text { abordando } \\
\text { temas } \\
\text { específicos } \\
\text { com a equipe } \\
\text { de } \\
\text { enfermagem } \\
\text { do Hospital. }\end{array}$ & $\begin{array}{l}\text { Os temas das } \\
\text { Rodas de Conversa } \\
\text { são escolhidos com } \\
\text { base nos } \\
\text { diagnósticos dos } \\
\text { pacientes } \\
\text { internados e na } \\
\text { relevância, além do } \\
\text { levantamento de } \\
\text { necessidades e de } \\
\text { conduta. Os } \\
\text { residentes de } \\
\text { enfermagem são os } \\
\text { responsáveis pelo } \\
\text { direcionamento dos } \\
\text { assuntos. }\end{array}$ & $\begin{array}{l}\text { * Criar espaços } \\
\text { coletivos para } \\
\text { discussão, avaliação } \\
\text { e reflexão dos atos } \\
\text { produzidos no } \\
\text { cotidiano. } \\
\text { * Estimular e facilitar } \\
\text { o processo de } \\
\text { ensino- } \\
\text { aprendizagem. } \\
\text { * Relacionar o } \\
\text { aprendizado com a } \\
\text { prática assistencial e } \\
\text { buscar melhorias na } \\
\text { qualidade do serviço } \\
\text { prestado ao usuário, } \\
\text { levando-se em } \\
\text { consideração, nesse } \\
\text { processo, as } \\
\text { vivências, os } \\
\text { pensamentos e os } \\
\text { saberes de cada } \\
\text { integrante da equipe. }\end{array}$ & \multirow{3}{*}{$\begin{array}{l}\text { II. REALIZAÇÃO } \\
\text { DE PRÁTICAS } \\
\text { EDUCACIONAIS } \\
\text { EM ESPAÇOS } \\
\text { COLETIVOS DE } \\
\text { TRABALHO }\end{array}$} \\
\hline $\begin{array}{l}\text { "Aprender de um } \\
\text { modo diferente } \\
\text { pode mesmo fazer } \\
\text { a diferença? Novas } \\
\text { reflexões" }\end{array}$ & $\begin{array}{l}\text { Curso de } \\
\text { Sistema } \\
\text { Integrado de } \\
\text { Administração } \\
\text { de Pessoal. }\end{array}$ & \begin{tabular}{|l|} 
Reflexões \\
promovidas no \\
campo dos \\
servidores \\
diretamente \\
envolvidos na \\
atenção à saúde.
\end{tabular} & $\begin{array}{l}\text { Reduzir pilhas de } \\
\text { processos pendentes. }\end{array}$ & \\
\hline $\begin{array}{l}\text { "EpiSUS: uma } \\
\text { experiência bem- } \\
\text { sucedida no } \\
\text { atendimento às } \\
\text { emergências em } \\
\text { saúde pública” }\end{array}$ & $\begin{array}{l}\text { Estratégias de } \\
\text { aprendizagem } \\
\text { em serviço. }\end{array}$ & $\begin{array}{l}\text { Na narrativa, é } \\
\text { destacada a } \\
\text { metodologia do } \\
\text { "aprender fazendo". } \\
\text { É desenvolvido } \\
\text { durante dois anos, } \\
\text { em que os } \\
\text { participantes } \\
\text { desenvolvem suas } \\
\text { atividades nas } \\
\text { diferentes áreas } \\
\text { técnicas que } \\
\text { compõem a } \\
\text { Secretaria de } \\
\text { Vigilância em Saúde } \\
\text { e são deslocados } \\
\text { para as atividades }\end{array}$ & $\begin{array}{l}\text { Aprimorar a } \\
\text { capacidade técnica } \\
\text { de profissionais de } \\
\text { saúde por meio de } \\
\text { ações de } \\
\text { aprendizagem em } \\
\text { serviço para atuar na } \\
\text { Vigilância em Saúde, } \\
\text { prioritariamente nas } \\
\text { emergências em } \\
\text { saúde pública, no } \\
\text { âmbito do SUS. }\end{array}$ & \\
\hline
\end{tabular}


continuação

\begin{tabular}{|c|c|c|c|c|}
\hline Narrativas & Ações & Método & $\begin{array}{l}\text { Objetivo(s) das } \\
\text { ações }\end{array}$ & Diretriz \\
\hline & & $\begin{array}{l}\text { de investigações de } \\
\text { campo sempre que } \\
\text { ocorre uma } \\
\text { emergência em } \\
\text { saúde pública, em } \\
\text { qualquer parte do } \\
\text { País, ou quando } \\
\text { solicitado até em } \\
\text { âmbito } \\
\text { internacional. }\end{array}$ & & \\
\hline
\end{tabular}

$\mathrm{Na}$ sequência, a diretriz que também se destaca é a que trata da "Contribuição para o enfrentamento da fragmentação dos serviços e das ações de saúde", apresentando-se em doze experiências, conforme demonstrado no quadro que se segue, com três narrativas que exemplificam essa correlação entre as ações, métodos, objetivos e a referida diretriz. Novamente, a pesquisadora fez a escolha por essas três narrativas por apresentarem informações em todos os campos necessários para análise.

Quadro 5 - Correlação entre ações, métodos, objetivos e a diretriz da Pneps correspondente (Contribuição para o enfrentamento da fragmentação dos serviços e ações de saúde)

\begin{tabular}{|c|c|c|c|c|}
\hline Narrativas & Ações & Método & $\begin{array}{c}\text { Objetivo(s) das } \\
\text { Ações }\end{array}$ & Diretriz \\
\hline $\begin{array}{l}\text { "Gerenciamento } \\
\text { das filas } \\
\text { cirúrgicas em um } \\
\text { dos hospitais } \\
\text { federais } \\
\text { localizado no Rio } \\
\text { de Janeiro: relato } \\
\text { de experiência" }\end{array}$ & $\begin{array}{l}\text { Rodas de } \\
\text { conversa }\end{array}$ & $\begin{array}{l}\text { Valorização e } \\
\text { utilização das } \\
\text { experiências dos } \\
\text { profissionais como } \\
\text { potencial criativo. }\end{array}$ & $\begin{array}{l}\text { Apresentar um plano } \\
\text { de ação para } \\
\text { organizar e realizar } \\
\text { cirurgias dos } \\
\text { pacientes inscritos } \\
\text { nas filas, conforme } \\
\text { prazos e formalidade } \\
\text { descritos na ação } \\
\text { judicial apresentada à } \\
\text { União, ao estado e ao } \\
\text { município do Rio de } \\
\text { Janeiro. }\end{array}$ & $\begin{array}{c}\text { VIII. } \\
\text { CONTRIBUIÇÃO }\end{array}$ \\
\hline $\begin{array}{l}\text { "I Capacitação } \\
\text { em atuação } \\
\text { multidisciplinar } \\
\text { na assistência } \\
\text { farmacêutica do } \\
\text { Dsei Potiguara" }\end{array}$ & $\begin{array}{l}\text { Capacitação } \\
\text { em atuaçãa } \\
\text { multidisciplinar } \\
\text { na assistência } \\
\text { farmacêutica. }\end{array}$ & $\begin{array}{l}\text { Foi utilizada como } \\
\text { estratégia e } \\
\text { metodologia uma } \\
\text { abordagem em } \\
\text { conformidade com } \\
\text { os objetivos, } \\
\text { atribuições, } \\
\text { princípios e } \\
\text { diretrizes do SUS, } \\
\text { assim como o } \\
\text { Subsistema de } \\
\text { Atenção à Saúde } \\
\text { Indígena e a } \\
\text { utilização de } \\
\text { conteúdos } \\
\text { relacionados com }\end{array}$ & $\begin{array}{l}\text { Debater, compartilhar } \\
\text { e orientar os } \\
\text { profissionais que } \\
\text { atuam nas equipes de } \\
\text { saúde, sobre as } \\
\text { atividades } \\
\text { relacionadas à } \\
\text { assistência } \\
\text { farmacêutica, com o } \\
\text { propósito final de } \\
\text { melhorar as ações de } \\
\text { saúde, ampliar o } \\
\text { acesso da população } \\
\text { indígena aos } \\
\text { medicamentos } \\
\text { essenciais e }\end{array}$ & $\begin{array}{l}\text { ENFRENTAMENTO } \\
\text { DA } \\
\text { FRAGMENTAÇÃO } \\
\text { DOS SERVIÇOS E } \\
\text { DAS AÇÕES DE } \\
\text { SAÚDE }\end{array}$ \\
\hline
\end{tabular}


continuação

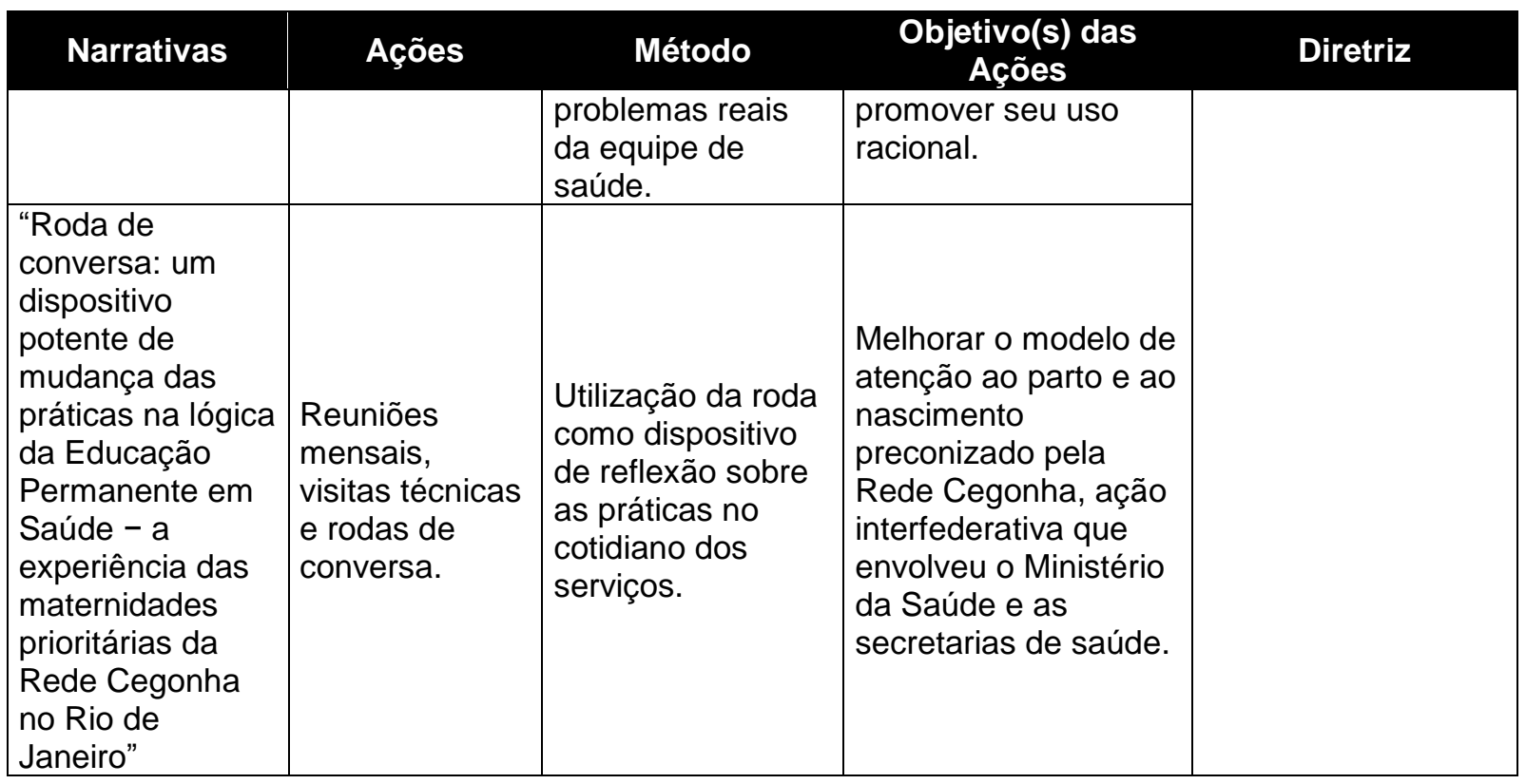

Em relação à diretriz correspondente à "Valorização do trabalhador e do trabalho em saúde", foram identificadas somente três narrativas, conforme destacado no Quadro 6.

Quadro 6 - Correlação entre ações, métodos, objetivos e a diretriz da Pneps correspondente (Valorização do trabalhador e do trabalho em saúde)

\begin{tabular}{|c|c|c|c|c|}
\hline Narrativas & Ações & Método & $\begin{array}{c}\text { Objetivo(s) das } \\
\text { Ações }\end{array}$ & Diretriz \\
\hline $\begin{array}{l}\text { "A importância da } \\
\text { educação para o } \\
\text { desenvolvimento } \\
\text { pessoal e } \\
\text { organizacional no } \\
\text { serviço público" }\end{array}$ & $\begin{array}{l}\text { Oferta de } \\
\text { cursos aos } \\
\text { agentes } \\
\text { administrativos } \\
\text { do Into no ano } \\
\text { de } 2010, \\
\text { seguida de } \\
\text { pesquisa para } \\
\text { obter } \\
\text { informações } \\
\text { sobre as } \\
\text { percepções } \\
\text { dos } \\
\text { participantes a } \\
\text { respeito dos } \\
\text { cursos } \\
\text { realizados. }\end{array}$ & $\begin{array}{l}\text { Realização de } \\
\text { pesquisa de campo } \\
\text { com utilização de } \\
\text { questionário como } \\
\text { instrumento para } \\
\text { captação de } \\
\text { informações. } \\
\text { Também foi } \\
\text { realizada pesquisa } \\
\text { bibliográfica para } \\
\text { elaboração do } \\
\text { questionário e } \\
\text { interpretação dos } \\
\text { dados. }\end{array}$ & $\begin{array}{l}\text { Verificar a } \\
\text { importância da } \\
\text { educação para o } \\
\text { desenvolvimento } \\
\text { pessoal e } \\
\text { organizacional do } \\
\text { Into, a partir da } \\
\text { percepção dos } \\
\text { agentes } \\
\text { administrativos sobre } \\
\text { os cursos nos quais } \\
\text { participaram no ano } \\
\text { de } 2010 \text {. }\end{array}$ & $\begin{array}{c}\text { I. } \\
\text { VALORIZAÇÃO } \\
\text { DO } \\
\text { TRABALHADOR } \\
\text { E DO } \\
\text { TRABALHO EM } \\
\text { SAÚDE }\end{array}$ \\
\hline $\begin{array}{l}\text { "Coletivo MS: } \\
\text { projeto de } \\
\text { valorização do } \\
\text { trabalho e dos } \\
\text { trabalhadores do } \\
\text { Ministério da } \\
\text { Saúde" }\end{array}$ & $\begin{array}{l}\text { Não foram } \\
\text { apresentadas } \\
\text { na narrativa as } \\
\text { ações } \\
\text { desenvolvidas. }\end{array}$ & $\begin{array}{l}\text { Não foi apresentado } \\
\text { o método utilizado. }\end{array}$ & $\begin{array}{l}\text { Melhorar os canais de } \\
\text { comunicação, } \\
\text { promover a contínua } \\
\text { articulação e } \\
\text { integração das } \\
\text { diversas equipes e } \\
\text { aprimorar a gestão } \\
\text { com a contribuição } \\
\text { dos trabalhadores do } \\
\text { Ministério da Saúde; }\end{array}$ & \\
\hline
\end{tabular}


continuação

\begin{tabular}{|c|c|c|c|c|}
\hline Narrativas & Ações & Método & $\begin{array}{c}\text { Objetivo(s) das } \\
\text { Ações }\end{array}$ & Diretriz \\
\hline & & & $\begin{array}{l}\text { potencializar os } \\
\text { movimentos } \\
\text { participativos no MS. }\end{array}$ & \\
\hline $\begin{array}{l}\text { "Sarau literário no } \\
\text { Nerj” }\end{array}$ & Sarau literário & $\begin{array}{l}\text { “[...] o Sarau } \\
\text { experimenta } \\
\text { encontros - abrindo } \\
\text { espaço para } \\
\text { 'artistas- } \\
\text { trabalhadores' } \\
\text { apresentarem } \\
\text { produções próprias } \\
\text { e inovadoras, bem } \\
\text { como terem contato } \\
\text { com escritores } \\
\text { consagrados.” }\end{array}$ & $\begin{array}{l}\text { Oferecer aos } \\
\text { servidores do Núcleo } \\
\text { Estadual do Ministério } \\
\text { da Saúde no Rio de } \\
\text { Janeiro e dos } \\
\text { hospitais federais um } \\
\text { contato com a poesia } \\
\text { dos principais poetas } \\
\text { do Brasil e do mundo, } \\
\text { bem como estimular a } \\
\text { produção de textos } \\
\text { destes trabalhadores. }\end{array}$ & \\
\hline
\end{tabular}

$\mathrm{Na}$ narrativa intitulada "Coletivo MS: projeto de valorização do trabalho e dos trabalhadores do Ministério da Saúde", como é possível constatar no Quadro 6, não foram apresentadas as ações realizadas, tampouco o método utilizado para desenvolvimento da experiência. No entanto, para correlacionar a narrativa à diretriz de "Valorização do trabalhador e do trabalho em saúde", foi analisada somente a coluna "Objetivo(s) das ações", a qual possibilitou a correspondência com a referida diretriz da Pneps.

No que diz respeito à diretriz da "Promoção de aprendizagem significativa com uso de metodologias ativas e críticas", foram identificadas apenas três narrativas, conforme quadro a seguir.

Quadro 7 - Correlação entre ações, métodos, objetivos e a diretriz da Pneps correspondente (Promoção de aprendizagem significativa com uso de metodologias ativas e críticas)

\begin{tabular}{|c|c|c|c|c|}
\hline Narrativas & Ações & Método & $\begin{array}{c}\text { Objetivo(s) das } \\
\text { Acões }\end{array}$ & Diretriz \\
\hline $\begin{array}{l}\text { "Aperfeiçoamento } \\
\text { sobre as } \\
\text { atribuições e } \\
\text { competências dos } \\
\text { AIS, Aisans e } \\
\text { profissionais do } \\
\text { DSEI Yanomami" }\end{array}$ & $\begin{array}{l}\text { Rodas de } \\
\text { conversa, } \\
\text { trabalhos em } \\
\text { grupo e } \\
\text { dinâmicas } \\
\text { para } \\
\text { desenvolver o } \\
\text { processo de } \\
\text { capacitação } \\
\text { dos agentes } \\
\text { indígenas de } \\
\text { saúde (AIS). }\end{array}$ & $\begin{array}{l}\text { São utilizados } \\
\text { métodos e processos } \\
\text { participativos e } \\
\text { problematizadores } \\
\text { no processo } \\
\text { dialógico de } \\
\text { construção e } \\
\text { reconstrução } \\
\text { compartilhada, } \\
\text { fazendo sempre } \\
\text { relação entre teoria e } \\
\text { prática. Nas } \\
\text { capacitações e } \\
\text { oficinas há } \\
\text { momentos de } \\
\text { diálogos, troca de } \\
\text { experiências, }\end{array}$ & $\begin{array}{l}\text { Capacitar os agentes } \\
\text { indígenas de saúde } \\
\text { em técnicas de } \\
\text { transporte e em } \\
\text { como agir em } \\
\text { situações de } \\
\text { emergência, sempre } \\
\text { focando na prática. }\end{array}$ & $\begin{array}{l}\text { III. PROMOÇÃO } \\
\text { DE } \\
\text { APRENDIZAGEM } \\
\text { SIGNIFICATIVA } \\
\text { COM USO DE } \\
\text { METODOLOGIAS } \\
\text { ATIVAS E } \\
\text { CRÍTICAS }\end{array}$ \\
\hline
\end{tabular}


continuação

\begin{tabular}{|c|c|c|c|c|}
\hline Narrativas & Ações & Método & $\begin{array}{c}\text { Objetivo(s) das } \\
\text { Ações }\end{array}$ & Diretriz \\
\hline & & $\begin{array}{l}\text { levantamento de } \\
\text { problemas e de } \\
\text { soluções nas quais } \\
\text { os participantes } \\
\text { repensam suas } \\
\text { práticas. }\end{array}$ & & \\
\hline $\begin{array}{l}\text { "Avaliação do } \\
\text { processo de } \\
\text { trabalho: atuação } \\
\text { da área técnica de } \\
\text { alimentação e } \\
\text { nutrição na } \\
\text { vigilância } \\
\text { alimentar e } \\
\text { nutricional do Dsei } \\
\text { Pernambuco" }\end{array}$ & $\begin{array}{l}\text { Atualizações } \\
\text { em vigilância } \\
\text { alimentar e } \\
\text { nutricional } \\
\text { (VAN) para os } \\
\text { agentes } \\
\text { indígenas de } \\
\text { saúde (AIS) do } \\
\text { Distrito } \\
\text { Sanitário } \\
\text { Especial } \\
\text { Indígena } \\
\text { (Dsei) de } \\
\text { Pernambuco. }\end{array}$ & $\begin{array}{l}\text { Atualizações } \\
\text { fundamentadas na } \\
\text { problematização e } \\
\text { na dialética } \\
\text { apresentadas na } \\
\text { obra de Paulo Freire. } \\
\text { Dinâmicas que } \\
\text { buscam formas } \\
\text { participativas para } \\
\text { construção do } \\
\text { conhecimento. } \\
\text { Construção de } \\
\text { materiais educativos } \\
\text { tendo como base a } \\
\text { estratégia da } \\
\text { educação popular } \\
\text { em saúde. }\end{array}$ & $\begin{array}{l}\text { Capacitar os agentes } \\
\text { indígenas de saúde } \\
\text { em vigilância } \\
\text { alimentar e } \\
\text { nutricional. }\end{array}$ & \\
\hline $\begin{array}{l}\text { "Encontros e } \\
\text { movimentos: a } \\
\text { educação } \\
\text { permanente em } \\
\text { cena" }\end{array}$ & $\begin{array}{l}\text { Encontros } \\
\text { entre os } \\
\text { trabalhadores } \\
\text { do } \\
\text { Departamento } \\
\text { de Gestão da } \\
\text { Educação na } \\
\text { Saúde. }\end{array}$ & $\begin{array}{l}\text { Nos encontros são } \\
\text { utilizadas } \\
\text { metodologias de } \\
\text { facilitação } \\
\text { associadas entre um } \\
\text { momento e outro. } \\
\text { Num dos encontros } \\
\text { foi utilizada a } \\
\text { metodologia das } \\
\text { árvores com o } \\
\text { objetivo de } \\
\text { possibilitar a } \\
\text { correlação } \\
\text { metafórica entre as } \\
\text { ações realizadas e } \\
\text { as principais partes } \\
\text { de uma planta } \\
\text { (raízes, tronco e } \\
\text { copa). }\end{array}$ & $\begin{array}{l}\text { Trazer novos olhares } \\
\text { sobre o trabalho, } \\
\text { fomentar novas } \\
\text { reflexões, dar } \\
\text { continuidade aos } \\
\text { trabalhos em grupo } \\
\text { (modo de } \\
\text { organização do } \\
\text { departamento) para } \\
\text { a troca e } \\
\text { compartilhamento de } \\
\text { ideias, pensamentos, } \\
\text { proposições e afetos. }\end{array}$ & \\
\hline
\end{tabular}

Em referência à diretriz da Pneps que trata do "Favorecimento de autonomia e corresponsabilização de sujeitos nos processos de trabalho", foram identificadas quatro narrativas correspondentes. No Quadro 8, as duas primeiras experiências: "Aprendizagem no trabalho: a experiência da Coordenação-Geral de Gestão de Pessoas em seus cafés participativos"; e "Construção coletiva das metas e indicadores de avaliação de desempenho das equipes da Coordenação-Geral de Gestão de Pessoas"; além de se correlacionarem à diretriz acerca do "Favorecimento de autonomia e corresponsabilização de sujeitos nos processos de 
trabalho", também estão relacionadas à diretriz que trata da "Contribuição para a mudança cultural e institucional direcionada à gestão compartilhada e ao aprimoramento do SUS".

Quadro 8 - Correlação entre ações, métodos, objetivos e a diretriz da Pneps correspondente (Favorecimento de autonomia e corresponsabilização de sujeitos nos processos de trabalho)

\begin{tabular}{|c|c|c|c|c|}
\hline Narrativas & Ações & Método & $\begin{array}{c}\text { Objetivo (s) das } \\
\text { Ações }\end{array}$ & Diretriz \\
\hline $\begin{array}{l}\text { "Aprendizagem } \\
\text { no trabalho: a } \\
\text { experiência da } \\
\text { Coordenação- } \\
\text { Geral de Gestão } \\
\text { de Pessoas em } \\
\text { seus cafés } \\
\text { participativos" }\end{array}$ & $\begin{array}{l}\text { Encontros, } \\
\text { denominados } \\
\text { Cafés } \\
\text { Participativos, } \\
\text { com todas as } \\
\text { equipes da } \\
\text { Coordenação- } \\
\text { Geral de } \\
\text { Gestão de } \\
\text { Pessoas. }\end{array}$ & $\begin{array}{l}\text { Nos encontros, } \\
\text { cada } \\
\text { trabalhador } \\
\text { tem a } \\
\text { oportunidade } \\
\text { de compartilhar } \\
\text { suas atividades } \\
\text { e de também } \\
\text { propor } \\
\text { melhorias para } \\
\text { seus } \\
\text { processos de } \\
\text { trabalho e para } \\
\text { a Cgesp. }\end{array}$ & $\begin{array}{l}\text { Promoção da } \\
\text { melhoria contínua } \\
\text { dos processos de } \\
\text { trabalho na } \\
\text { perspectiva da } \\
\text { gestão } \\
\text { compartilhada. }\end{array}$ & $\begin{array}{c}\text { IV. FAVORECIMENTO DE } \\
\text { AUTONOMIA E } \\
\text { CORRESPONSABILIZAÇÃO } \\
\text { DE SUJEITOS NOS } \\
\text { PROCESSOS DE } \\
\text { TRABALHO } \\
\text { e } \\
\text { VII. CONTRIBUIÇÃO PARA } \\
\text { A MUDANÇA CULTURAL E } \\
\text { INSTITUCIONAL } \\
\text { DIRECIONADA À GESTÃO } \\
\text { COMPARTILHADA E AO } \\
\text { APRIMORAMENTO DO } \\
\text { SUS }\end{array}$ \\
\hline $\begin{array}{l}\text { "Construção } \\
\text { coletiva das } \\
\text { metas e } \\
\text { indicadores de } \\
\text { avaliação de } \\
\text { desempenho } \\
\text { das equipes da } \\
\text { Coordenação- } \\
\text { Geral de Gestão } \\
\text { de Pessoas" }\end{array}$ & $\begin{array}{l}\text { Criação de } \\
\text { espaços de } \\
\text { diálogos e de } \\
\text { construção } \\
\text { coletiva. }\end{array}$ & $\begin{array}{l}\text { A estratégia de } \\
\text { construção de } \\
\text { metas por } \\
\text { equipes de } \\
\text { trabalho foi } \\
\text { pactuada no } \\
\text { Colegiado } \\
\text { Gestor da } \\
\text { Coordenação- } \\
\text { Geral de } \\
\text { Gestão de } \\
\text { Pessoas. }\end{array}$ & $\begin{array}{l}\text { Construção } \\
\text { coletiva de metas } \\
\text { para avaliação de } \\
\text { desempenho no } \\
\text { ciclo 2012-2013. }\end{array}$ & $\begin{array}{c}\text { IV. FAVORECIMENTO DE } \\
\text { AUTONOMIA E } \\
\text { CORRESPONSABILIZAÇÃO } \\
\text { DE SUJEITOS NOS } \\
\text { PROCESSOS DE } \\
\text { TRABALHO } \\
\text { e } \\
\text { VII. CONTRIBUIÇÃO PARA } \\
\text { A MUDANÇA CULTURAL E } \\
\text { INSTITUCIONAL } \\
\text { DIRECIONADA À GESTÃO } \\
\text { COMPARTILHADA E AO } \\
\text { APRIMORAMENTO DO } \\
\text { SUS }\end{array}$ \\
\hline $\begin{array}{l}\text { "Educação } \\
\text { Permanente em } \\
\text { Saúde por meio } \\
\text { do projeto } \\
\text { Compartilhando } \\
\text { o Conhecimento" }\end{array}$ & $\begin{array}{l}\text { Roda de } \\
\text { conversa, } \\
\text { café com } \\
\text { ideias, MS } \\
\text { participativo, } \\
\text { projetos de } \\
\text { integração } \\
\text { social. }\end{array}$ & $\begin{array}{l}\text { Não foi } \\
\text { apresentado o } \\
\text { método } \\
\text { utilizado. }\end{array}$ & $\begin{array}{l}\text { Garantir a } \\
\text { melhora dos } \\
\text { processos de } \\
\text { trabalho, a } \\
\text { valorização do } \\
\text { conhecimento, o } \\
\text { desenvolvimento } \\
\text { de novas } \\
\text { competências e a } \\
\text { integração das } \\
\text { diversas áreas } \\
\text { que compõem o } \\
\text { Serviço de Gestão } \\
\text { Administrativa do } \\
\text { Núcleo Estadual } \\
\text { do Ministério da } \\
\text { Saúde no Ceará. }\end{array}$ & $\begin{array}{l}\text { IV. FAVORECIMENTO DE } \\
\text { AUTONOMIA E } \\
\text { CORRESPONSABILIZAÇÃO } \\
\text { DE SUJEITOS NOS } \\
\text { PROCESSOS DE } \\
\text { TRABALHO }\end{array}$ \\
\hline
\end{tabular}


continuação

\begin{tabular}{|c|c|c|c|c|}
\hline Narrativas & Ações & Método & $\begin{array}{c}\text { Objetivo (s) das } \\
\text { Ações }\end{array}$ & Diretriz \\
\hline $\begin{array}{l}\text { "Rodas de } \\
\text { conversa: uma } \\
\text { forma de refletir } \\
\text { e dialogar sobre } \\
\text { o trabalho em } \\
\text { saúde" }\end{array}$ & $\begin{array}{l}\text { Rodas de } \\
\text { conversa. }\end{array}$ & $\begin{array}{l}\text { Nas rodas de } \\
\text { conversa são } \\
\text { promovidos } \\
\text { espaços de } \\
\text { diálogo e troca } \\
\text { de } \\
\text { experiências } \\
\text { de forma crítica } \\
\text { e reflexiva. }\end{array}$ & $\begin{array}{l}\text { "[...] estimular o } \\
\text { compartilhamento } \\
\text { e a socialização } \\
\text { das experiências } \\
\text { e das ações } \\
\text { desenvolvidas } \\
\text { pelas áreas } \\
\text { técnicas, } \\
\text { proporcionando a } \\
\text { difusão de } \\
\text { conhecimento } \\
\text { teórico e prático } \\
\text { produzido no } \\
\text { DDAHV - e outros } \\
\text { setores do MS - } \\
\text { num espaço } \\
\text { permanente de } \\
\text { reflexão, } \\
\text { estimulando o } \\
\text { estabelecimento } \\
\text { de vínculos } \\
\text { solidários, } \\
\text { integração, } \\
\text { autonomia e } \\
\text { protagonismo dos } \\
\text { trabalhadores." }\end{array}$ & $\begin{array}{l}\text { IV. FAVORECIMENTO DE } \\
\text { AUTONOMIA E } \\
\text { CORRESPONSABILIZAÇÃO } \\
\text { DE SUJEITOS NOS } \\
\text { PROCESSOS DE } \\
\text { TRABALHO }\end{array}$ \\
\hline
\end{tabular}

No Quadro 9, a seguir, foi identificada apenas uma narrativa correspondente à diretriz do "Fortalecimento da gestão da educação permanente em saúde de forma compartilhada e participativa".

Quadro 9 - Correlação entre ações, métodos, objetivos e a diretriz da Pneps correspondente (Fortalecimento da gestão da educação permanente em saúde de forma compartilhada e participativa)

\begin{tabular}{|c|c|c|c|c|}
\hline Narrativa & Ações & Método & $\begin{array}{c}\text { Objetivo(s) das } \\
\text { Ações }\end{array}$ & Diretriz \\
\hline $\begin{array}{l}\text { "Formação em } \\
\text { Educação } \\
\text { Permanente em } \\
\text { Saúde: grupo de } \\
\text { trabalho 3" }\end{array}$ & $\begin{array}{l}\text { Elaboração de } \\
\text { materiais } \\
\text { informativos; } \\
\text { construção de } \\
\text { estratégias que } \\
\text { favoreçam a } \\
\text { integração dos } \\
\text { trabalhadores } \\
\text { do } \\
\text { departamento; } \\
\text { organização de } \\
\text { material sobre } \\
\text { a formação de } \\
\text { apoiadores do } \\
\text { departamento; } \\
\text { e construção } \\
\text { de projeto de } \\
\text { formação em }\end{array}$ & $\begin{array}{l}\text { São realizados } \\
\text { encontros entre } \\
\text { os trabalhadores } \\
\text { do Departamento } \\
\text { de Gestão da } \\
\text { Educação na } \\
\text { Saúde. }\end{array}$ & $\begin{array}{l}\text { Elaborar propostas } \\
\text { de formação em } \\
\text { saúde que } \\
\text { fortaleçam a Política } \\
\text { Nacional de } \\
\text { Educação } \\
\text { Permanente, tanto } \\
\text { no âmbito interno } \\
\text { quanto externo ao } \\
\text { Deges, as quais } \\
\text { estejam ancoradas } \\
\text { em mudanças do } \\
\text { fazer no cotidiano do } \\
\text { trabalho que } \\
\text { possibilitem } \\
\text { melhorias nos } \\
\text { serviços de saúde. }\end{array}$ & $\begin{array}{c}\text { VI. } \\
\text { FORTALECIMENTO } \\
\text { DA GESTÃO DA } \\
\text { EDUCAÇÃO } \\
\text { PERMANENTE EM } \\
\text { SAÚDE DE FORMA } \\
\text { COMPARTILHADA } \\
\text { E PARTICIPATIVA }\end{array}$ \\
\hline
\end{tabular}


continuação

\begin{tabular}{|c|c|c|c|c|}
\hline Narrativa & Ações & Método & $\begin{array}{c}\text { Objetivo(s) das } \\
\text { Ações }\end{array}$ & Diretriz \\
\hline & $\begin{array}{l}\text { EPS nas redes } \\
\text { prioritárias. }\end{array}$ & & & \\
\hline
\end{tabular}

Já em relação à diretriz da Pneps que trata da "Contribuição para a mudança cultural e institucional direcionada à gestão compartilhada e ao aprimoramento do SUS", foram identificadas narrativas que, somadas àquelas duas narrativas que também tratam da diretriz "Favorecimento de autonomia e corresponsabilização de sujeitos nos processos de trabalho", citadas no Quadro 8, totalizam cinco narrativas relacionadas.

Quadro 10 - Correlação entre ações, métodos, objetivos e a diretriz da Pneps correspondente (Contribuição para a mudança cultural e institucional direcionada à gestão compartilhada e ao aprimoramento do SUS)

\begin{tabular}{|c|c|c|c|c|}
\hline Narrativas & Ações & Método & $\begin{array}{l}\text { Objetivo(s) das } \\
\text { Ações }\end{array}$ & Diretriz \\
\hline $\begin{array}{l}\text { "Encontros e } \\
\text { movimentos: a } \\
\text { formação em } \\
\text { Educação } \\
\text { Permanente em } \\
\text { Saúde" }\end{array}$ & $\begin{array}{l}\text { Encontros } \\
\text { entre os } \\
\text { trabalhadores }\end{array}$ & $\begin{array}{l}\text { Nos encontros, são } \\
\text { utilizadas } \\
\text { metodologias de } \\
\text { facilitação } \\
\text { associadas entre } \\
\text { um momento e } \\
\text { outro. }\end{array}$ & $\begin{array}{l}\text { Os encontros são } \\
\text { promovidos para } \\
\text { trocas com } \\
\text { profissionais da Saúde } \\
\text { Coletiva e para a } \\
\text { continuidade dos } \\
\text { grupos de trabalho } \\
\text { para troca e } \\
\text { compartilhamento de } \\
\text { ideias, pensamentos, } \\
\text { proposições e afetos, } \\
\text { objetivando a } \\
\text { problematização do } \\
\text { cotidiano do trabalho. }\end{array}$ & \multirow{2}{*}{$\begin{array}{c}\text { VII. } \\
\text { CONTRIBUIÇÃO } \\
\text { PARA A } \\
\text { MUDANÇA } \\
\text { CULTURAL E } \\
\text { INSTITUCIONAL } \\
\text { DIRECIONADA À } \\
\text { GESTÃO } \\
\text { COMPARTILHADA } \\
\text { E AO } \\
\text { APRIMORAMENTO } \\
\text { DO SUS }\end{array}$} \\
\hline $\begin{array}{l}\text { "Excelência da } \\
\text { gestão pública: } \\
\text { o caso } \\
\text { DataSUS/PB" }\end{array}$ & $\begin{array}{l}\text { Oficinas de } \\
\text { autoavaliação } \\
\text { da gestão } \\
\text { pública. }\end{array}$ & $\begin{array}{l}\text { Nas oficinas é } \\
\text { utilizado o } \\
\text { Instrumento de } \\
\text { Avaliação da } \\
\text { Gestão Pública } \\
\text { (lagp) e a } \\
\text { elaboração do } \\
\text { Plano de Melhoria } \\
\text { da Gestão, } \\
\text { ferramentas do } \\
\text { Programa Nacional } \\
\text { da Gestão Pública } \\
\text { e } \\
\text { Desburocratização } \\
\text { (Gespública), } \\
\text { durante três dias de } \\
\text { imersão total. } \\
\end{array}$ & Avaliar a gestão. & \\
\hline
\end{tabular}


continuação

\begin{tabular}{|c|c|c|c|c|}
\hline Narrativas & Ações & Método & $\begin{array}{c}\text { Objetivo(s) das } \\
\text { Ações }\end{array}$ & Diretriz \\
\hline $\begin{array}{l}\text { "Oficina } \\
\text { itinerante de } \\
\text { gestão de } \\
\text { pessoas" }\end{array}$ & $\begin{array}{l}\text { Oficina } \\
\text { itinerante de } \\
\text { gestão de } \\
\text { pessoas. }\end{array}$ & $\begin{array}{l}\text { Oficinas para } \\
\text { reflexão e avaliação } \\
\text { de questões } \\
\text { problematizadas. }\end{array}$ & $\begin{array}{l}\text { Reflexão e avaliação } \\
\text { de questões } \\
\text { problematizadas para } \\
\text { melhorar a realidade } \\
\text { do trabalho. }\end{array}$ & \\
\hline
\end{tabular}

Por fim, foram identificadas quatro narrativas correspondentes à diretriz sobre a "Valorização das múltiplas dimensões humanas nos processos de ensinoaprendizagem", conforme é possível constatar no quadro que se segue.

Quadro 11 - Correlação entre ações, métodos, objetivos e a diretriz da Pneps correspondente (Valorização das múltiplas dimensões humanas nos processos de ensino-aprendizagem)

\begin{tabular}{|c|c|c|c|c|}
\hline Narrativas & Ações & Método & $\begin{array}{l}\text { Objetivo(s) das } \\
\text { Ações }\end{array}$ & Diretriz \\
\hline $\begin{array}{l}\text { "A arte na } \\
\text { Enfermagem } \\
\text { como estratégia } \\
\text { de transformação } \\
\text { das relações de } \\
\text { trabalho: oficina } \\
\text { do cuidador" }\end{array}$ & $\begin{array}{l}\text { Desenvolvimento } \\
\text { de atividades } \\
\text { lúdicas } \\
\text { envolvendo os } \\
\text { profissionais de } \\
\text { enfermagem do } \\
\text { Hospital. }\end{array}$ & $\begin{array}{l}\text { A arte foi utilizada } \\
\text { como instrumento de } \\
\text { transformação. }\end{array}$ & $\begin{array}{l}\text { Sensibilizar os } \\
\text { trabalhadores de } \\
\text { Enfermagem para } \\
\text { o } \\
\text { autoconhecimento } \\
\text { e estimular o } \\
\text { autocuidado. }\end{array}$ & \\
\hline $\begin{array}{l}\text { "A } \\
\text { intersetorialidade } \\
\text { e a participação } \\
\text { social como } \\
\text { instrumentos } \\
\text { potentes no } \\
\text { planejamento de } \\
\text { ações de } \\
\text { educação } \\
\text { permanente na } \\
\text { saúde indígena" }\end{array}$ & $\begin{array}{l}\text { Organização de } \\
\text { encontros com } \\
\text { um grupo } \\
\text { intersetorial para } \\
\text { estruturar a } \\
\text { capacitação dos } \\
\text { conselheiros. }\end{array}$ & $\begin{array}{l}\text { Inicialmente, formou- } \\
\text { se um grupo } \\
\text { intersetorial de } \\
\text { trabalho para pensar } \\
\text { na capacitação dos } \\
\text { conselheiros. Em } \\
\text { seguida, foram } \\
\text { realizados encontros } \\
\text { com esse grupo nos } \\
\text { quais os temas e a } \\
\text { metodologia a ser } \\
\text { adotada na } \\
\text { capacitação foram } \\
\text { discutidos. Para } \\
\text { discussão da } \\
\text { metodologia e dos } \\
\text { temas, também foram } \\
\text { convidados membro } \\
\text { da Fundação } \\
\text { Nacional do Índio } \\
\text { (Funai), da } \\
\text { Controladoria-Geral } \\
\text { da União (CGU) e da } \\
\text { Universidade Federal } \\
\text { de Santa Catarina } \\
\text { (UFSC). }\end{array}$ & $\begin{array}{l}\text { Organizar e } \\
\text { executar a } \\
\text { capacitação dos } \\
\text { conselheiros } \\
\text { distritais de saúde } \\
\text { indígena do } \\
\text { Distrito Sanitário } \\
\text { Especial Indígena } \\
\text { (Dsei) do Interior } \\
\text { Sul. }\end{array}$ & $\begin{array}{c}\text { IX. } \\
\text { VALORIZAÇÃO } \\
\text { DAS MÚLTIPLAS } \\
\text { DIMENSÕES } \\
\text { HUMANAS NOS } \\
\text { PROCESSOS DE } \\
\text { ENSINO- } \\
\text { APRENDIZAGEM }\end{array}$ \\
\hline
\end{tabular}


continuação

\begin{tabular}{|c|c|c|c|c|}
\hline Narrativas & Ações & Método & $\begin{array}{c}\text { Objetivo(s) das } \\
\text { Ações }\end{array}$ & Diretriz \\
\hline $\begin{array}{l}\text { "Capacitação das } \\
\text { equipes } \\
\text { multidisciplinares } \\
\text { de saúde } \\
\text { indígena, } \\
\text { lideranças e } \\
\text { professores para } \\
\text { atuação na } \\
\text { saúde mental } \\
\text { dos povos } \\
\text { indígenas com } \\
\text { ênfase no uso } \\
\text { indevido de } \\
\text { drogas lícitas e } \\
\text { ilícitas no Dsei } \\
\text { Ceará" }\end{array}$ & $\begin{array}{l}\text { Criação de } \\
\text { cordéis, canções, } \\
\text { versos e dramas } \\
\text { para a } \\
\text { disseminação } \\
\text { das informações } \\
\text { nas } \\
\text { comunidades. }\end{array}$ & \begin{tabular}{|l|} 
Associação de \\
conhecimentos \\
teóricos às atividades \\
de práticas descritas \\
pelos participantes \\
com os principais \\
atores da \\
comunidade. \\
Elaboração de um \\
plano de ação, \\
valorizando \\
conhecimentos \\
tradicionais, utilizando \\
meios de produção \\
espontâneos (cordéis, \\
canções, versos e \\
dramas).
\end{tabular} & $\begin{array}{l}\text { Desenvolver ações } \\
\text { de promoção e } \\
\text { prevenção do uso } \\
\text { de drogas lícitas e } \\
\text { ilícitas por meio da } \\
\text { capacitação das } \\
\text { equipes } \\
\text { multidisciplinares } \\
\text { de saúde } \\
\text { indígena, } \\
\text { favorecendo o } \\
\text { diálogo e a } \\
\text { integração para } \\
\text { enfrentamento do } \\
\text { problema. }\end{array}$ & \\
\hline $\begin{array}{l}\text { "Projeto baião de } \\
\text { dois" }\end{array}$ & $\begin{array}{l}\text { Reuniões e } \\
\text { encontros para } \\
\text { compartilhar } \\
\text { ideias. Práticas } \\
\text { educativas, com } \\
\text { a construção de } \\
\text { conhecimentos a } \\
\text { partir do sujeito e } \\
\text { a realidade do } \\
\text { trabalho, tendo } \\
\text { como pano de } \\
\text { fundo uma } \\
\text { concepção } \\
\text { freireana. }\end{array}$ & $\begin{array}{l}\text { Reuniões pautadas } \\
\text { no livre pensar, seja } \\
\text { na escolha da } \\
\text { temática, seja na } \\
\text { condução, ou, } \\
\text { principalmente, no } \\
\text { resultado final, haja } \\
\text { vista que as } \\
\text { considerações finais } \\
\text { são construídas por } \\
\text { consenso, pela } \\
\text { plenária. }\end{array}$ & $\begin{array}{l}\text { Enfrentamento das } \\
\text { constantes } \\
\text { mudanças, da } \\
\text { velocidade } \\
\text { vertiginosa das } \\
\text { informações e, } \\
\text { principalmente, } \\
\text { das insatisfações } \\
\text { geradas pelo } \\
\text { cotidiano do } \\
\text { trabalho. }\end{array}$ & \\
\hline
\end{tabular}

Em onze narrativas não foi possível identificar diretriz correlacionada. Em que pese não ser possível identificar diretrizes correlacionadas em tais narrativas, estas traziam outros elementos para análise, portanto foram consideradas como objeto deste estudo. Também não foi identificada narrativa que tratasse da diretriz acerca da "Articulação entre a Educação Permanente em Saúde e a gestão de pessoas por competências", conforme já informado no início deste tópico.

\subsection{Quais concepções de educação são apresentadas nas narrativas de experiências da 1ํㅡㄴ Mostra Nacional?}

Entre as 56 narrativas analisadas, foi possível identificar diferentes concepções de educação. Considerando a metodologia adotada neste trabalho, foram criados temas/categorias para agrupar tanto as concepções de educação 
destacadas nas narrativas quanto as concepções criadas pela pesquisadora a partir do referencial teórico adotado.

Dessa forma, foram criados onze temas/categorias, conforme a Tabela 2. Em algumas narrativas, foram identificados mais de um tema correlacionado. Para fins de quantificação, foi realizada a separação dos temas/ categorias. Portanto, o número total destacado na tabela apresenta a frequência com que os temas/ categorias se apresentam nas narrativas, não coincidindo, dessa forma, com o total de narrativas analisadas.

Tabela 2 - Quantitativo de narrativas segundo temas relacionados às concepções de educação identificadas

\begin{tabular}{l|c}
\hline TEMAS RELACIONADOS ÁS CONCEPÇÕES DE EDUCAÇÃO & TOTAL \\
\hline - Análise do cotidiano do trabalho & 2 \\
- Aprendizagem em serviço & 1 \\
- Aprendizagem significativa & 2 \\
- Compartilhamento de informações e saberes & $\mathbf{3 2}$ \\
- Desenvolvimento pessoal e organizacional & 4 \\
- Problematização & 3 \\
- Reflexão sobre a prática & $\mathbf{8}$ \\
- Trabalho como espaço de aprendizado & $\mathbf{1 1}$ \\
- Transformação de práticas & $\mathbf{9}$ \\
- Valorização e humanização dos profissionais & 1 \\
- Valorização de saberes prévios & 2 \\
\hline
\end{tabular}

A Tabela 2 sugere que a maior parte dos autores das narrativas publicadas na Coletânea da 1aㅡ Mostra, totalizando 32, entende educação como uma estratégia de compartilhamento de informações e saberes. Na sequência, temos onze autores que consideram o trabalho como espaço de aprendizado e nove avaliam que a educação implica transformação de práticas. Esses são os temas de maior prevalência.

Para trabalhar o tema "Compartilhamento de informações e saberes", foram utilizadas as concepções trazidas por Ceccim e Ferla (2008), segundo os quais a EPS pressupõe maior compartilhamento entre os coletivos de trabalho. A partir da análise das narrativas e do referencial teórico adotado, foi identificado o referido tema em 32 relatos, conforme exemplificado no Quadro 12. As três narrativas destacadas a seguir foram escolhidas por trazerem informações relevantes nos campos necessários para análise, seja a concepção de educação declarada 
expressamente no texto da narrativa ou a inferência feita pela pesquisadora quanto a determinados trechos que correspondem a concepções de educação que se relacionam ao tema em questão.

Quadro 12 - Correlação entre concepções de educação e o tema "Compartilhamento de informações e saberes"

\begin{tabular}{|c|c|c|c|}
\hline Narrativas & $\begin{array}{c}\text { Concepção de } \\
\text { educação destacada } \\
\text { no texto }\end{array}$ & Temas & $\begin{array}{c}\text { Inferências a partir de } \\
\text { trechos das narrativas que } \\
\text { correspondem a } \\
\text { concepções de educação }\end{array}$ \\
\hline $\begin{array}{l}\text { "A importância do } \\
\text { patrimônio para o } \\
\text { controle geral dos } \\
\text { bens do acervo do } \\
\text { Ministério da } \\
\text { Saúde" }\end{array}$ & $\begin{array}{l}\text { NÃO DECLARADA } \\
\text { EXPRESSAMENTE }\end{array}$ & \multirow{3}{*}{$\begin{array}{c}\text { COMPARTILHAMENTO } \\
\text { DE INFORMAÇÕES E } \\
\text { SABERES }\end{array}$} & $\begin{array}{l}\text { Destaca uma reflexão sobre } \\
\text { a importância do } \\
\text { envolvimento de toda a } \\
\text { equipe para que percebam o } \\
\text { quanto contribuem para o } \\
\text { resultado final de seu setor. }\end{array}$ \\
\hline $\begin{array}{l}\text { "Aprendizagem no } \\
\text { trabalho: a } \\
\text { experiência da } \\
\text { Coordenação-- } \\
\text { Geral de Gestão } \\
\text { de Pessoas em } \\
\text { seus cafés } \\
\text { participativos" }\end{array}$ & $\begin{array}{l}\text { NÃO DECLARADA } \\
\text { EXPRESSAMENTE }\end{array}$ & & $\begin{array}{l}\text { Destaca aspectos } \\
\text { correlacionados à EPS, } \\
\text { como: gestão compartilhada; } \\
\text { promoção de espaços } \\
\text { efetivos de gestão } \\
\text { participativa; integração } \\
\text { entre as equipes; e melhoria } \\
\text { dos processos de trabalho. }\end{array}$ \\
\hline $\begin{array}{l}\text { "Auditoria cidadã: } \\
\text { instrumento de } \\
\text { apoio à gestão do } \\
\text { Sistema Único de } \\
\text { Saúde" }\end{array}$ & $\begin{array}{l}\text { O procedimento } \\
\text { metodológico assumido } \\
\text { para a mudança no } \\
\text { processo de trabalho da } \\
\text { auditoria está } \\
\text { embasado no } \\
\text { compartilhamento e } \\
\text { interação de } \\
\text { tecnologias leve-duras } \\
\text { de Merhy e } \\
\text { Feuerwerker, entre os } \\
\text { técnicos da auditoria, } \\
\text { gestores e usuários do } \\
\text { SUS [...] }\end{array}$ & & - \\
\hline
\end{tabular}

Para categorizar as narrativas no tema "Trabalho como espaço de aprendizado", foram utilizadas como referências as concepções trazidas por Gadotti (2005) referente à educação não formal e Merhy et. al (2006), segundo os quais é possível classificar o trabalho como ambiente de aprendizado, ou seja, o trabalho deve funcionar como uma escola. Nesse tema, foram encontradas onze narrativas, conforme exemplificado com três narrativas no Quadro 13. Novamente, a escolha das narrativas destacadas no quadro que se segue se deu em razão do conjunto de informações trazidas nos campos necessários para análise. 
Quadro 13 - Correlação entre concepções de educação e o tema "Trabalho como espaço de aprendizado"

\begin{tabular}{|c|c|c|c|}
\hline Narrativas & $\begin{array}{c}\text { Concepção de } \\
\text { educação destacada } \\
\text { no texto }\end{array}$ & Temas & $\begin{array}{c}\text { Inferências a partir de } \\
\text { trechos das narrativas que } \\
\text { correspondem a } \\
\text { concepcões de educacão }\end{array}$ \\
\hline $\begin{array}{l}\text { "Ciclo de } \\
\text { Educação } \\
\text { Permanente em } \\
\text { Saúde em } \\
\text { odontologia na } \\
\text { Casai Macapá” }\end{array}$ & $\begin{array}{l}\text { NÃO DECLARADA } \\
\text { EXPRESSAMENTE }\end{array}$ & \multirow{4}{*}{$\begin{array}{l}\text { TRABALHO COMO } \\
\text { ESPAÇO DE } \\
\text { APRENDIZADO }\end{array}$} & $\begin{array}{l}\text { Destaca a relevância da } \\
\text { discussão sobre os } \\
\text { conceitos de EP e Educação } \\
\text { Continuada realizada } \\
\text { durante a Mostra e destaca } \\
\text { que o ambiente de trabalho } \\
\text { deve nos levar à busca de } \\
\text { novos conhecimentos para } \\
\text { melhorar os processos de } \\
\text { trabalho. }\end{array}$ \\
\hline $\begin{array}{l}\text { "Curso de } \\
\text { educação a } \\
\text { distância Saber } \\
\text { saúde: prevenção } \\
\text { do tabagismo e de } \\
\text { outros fatores de } \\
\text { risco para o } \\
\text { desenvolvimento } \\
\text { de doenças } \\
\text { crônicas não } \\
\text { transmissíveis" }\end{array}$ & $\begin{array}{l}{[\ldots . .] \text { o local de trabalho }} \\
\text { deve ser visto sempre } \\
\text { como um espaço de } \\
\text { aprendizado, troca e } \\
\text { interação }[\ldots]\end{array}$ & & 글 \\
\hline $\begin{array}{l}\text { "Oficina de } \\
\text { preenchimento das } \\
\text { fichas } \\
\text { odontológicas e } \\
\text { estruturação do } \\
\text { processo de } \\
\text { informação dos } \\
\text { dados de saúde } \\
\text { bucal indígena do } \\
\text { Dsei Amapá e } \\
\text { Norte do Pará" }\end{array}$ & $\begin{array}{l}{[\ldots] \text { o ambiente de }} \\
\text { trabalho nos leva à } \\
\text { busca de novos } \\
\text { conhecimentos para } \\
\text { que possamos } \\
\text { implementar novas } \\
\text { estratégias e melhorar } \\
\text { o nosso processo de } \\
\text { trabalho com o público- } \\
\text { alvo, de forma a obter } \\
\text { maior aproveitamento } \\
\text { das ações } \\
\text { implementadas }\end{array}$ & & - \\
\hline $\begin{array}{l}\text { "Primeira oficina } \\
\text { de planejamento } \\
\text { de ações voltadas } \\
\text { para a melhoria } \\
\text { das atividades de } \\
\text { Educação } \\
\text { Permanente em } \\
\text { Saúde no } \\
\text { NEMS/PA" }\end{array}$ & $\begin{array}{l}\text { [...] que a produção de } \\
\text { conhecimento pode } \\
\text { surgir no local de } \\
\text { trabalho, não deve ser } \\
\text { somente "importada" de } \\
\text { instituições externas, } \\
\text { mas, de todo modo, } \\
\text { cada uma tem a sua } \\
\text { importância. }\end{array}$ & & - \\
\hline
\end{tabular}

"Reflexão sobre a prática", de acordo com Merhy et. al (2006), é o que pode produzir o desconforto e a disposição para produzir alternativas de práticas e de conceitos, para enfrentar o desafio das transformações. Para definição desse tema, também foi adotado o que Freire (1996) fala sobre a necessidade de se pensar criticamente a prática atual para modificar práticas futuras. Em oito narrativas, foi 
possível identificar o tema "Reflexão sobre a prática", como é possível conferir nos exemplos citados no Quadro 14 e escolhidos em razão do conjunto de informações trazidas nos campos necessários para análise.

Quadro 14 - Correlação entre concepções de educação e o tema "Reflexão sobre a prática"

\begin{tabular}{|c|c|c|c|}
\hline Narrativas & $\begin{array}{l}\text { Concepção de } \\
\text { educação destacada } \\
\text { no texto }\end{array}$ & Temas & $\begin{array}{l}\text { Inferências a partir de } \\
\text { trechos das narrativas que } \\
\text { correspondem a } \\
\text { concepcões de educacão }\end{array}$ \\
\hline $\begin{array}{l}\text { "Capacitação das } \\
\text { equipes } \\
\text { multidisciplinares } \\
\text { de saúde indígena, } \\
\text { lideranças e } \\
\text { professores para } \\
\text { atuação na saúde } \\
\text { mental dos povos } \\
\text { indígenas com } \\
\text { ênfase no uso } \\
\text { indevido de drogas } \\
\text { lícitas e ilícitas no } \\
\text { Dsei Ceará” }\end{array}$ & $\begin{array}{l}\text { A estratégia de } \\
\text { Educação Permanente } \\
\text { em Saúde das equipes } \\
\text { multidisciplinares de } \\
\text { saúde indígena (EMSI) } \\
\text { em saúde mental no } \\
\text { Ceará busca associar } \\
\text { conhecimentos teóricos } \\
\text { às atividades de } \\
\text { práticas descritas pelos } \\
\text { participantes junto aos } \\
\text { principais atores da } \\
\text { comunidade, e, de } \\
\text { modo sinérgico, } \\
\text { desenvolver ações de } \\
\text { promoção e prevenção } \\
\text { do uso de drogas lícitas } \\
\text { e ilícitas. }\end{array}$ & \multirow[t]{3}{*}{$\begin{array}{c}\text { REFLEXÃO SOBRE A } \\
\text { PRÁTICA }\end{array}$} & 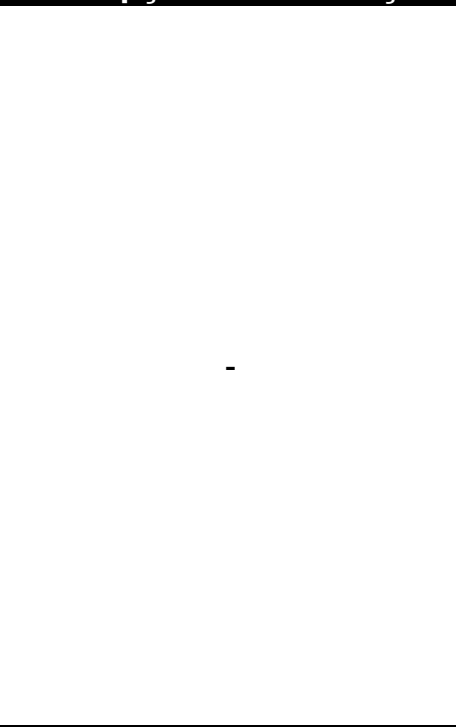 \\
\hline $\begin{array}{l}\text { "Excelência da } \\
\text { gestão pública: o } \\
\text { caso DataSUS/PB" }\end{array}$ & $\begin{array}{l}\text { NÃO DECLARADA } \\
\text { EXPRESSAMENTE }\end{array}$ & & $\begin{array}{l}\text { Destaca uma ação de } \\
\text { reflexão sobre a prática. }\end{array}$ \\
\hline $\begin{array}{l}\text { "Formação em } \\
\text { Educação } \\
\text { Permanente em } \\
\text { Saúde: grupo de } \\
\text { trabalho 3" }\end{array}$ & $\begin{array}{l}\text { Embora a EPS não } \\
\text { aconteça apenas em } \\
\text { espaços } \\
\text { institucionalizados, } \\
\text { percebe-se a } \\
\text { necessidade de se } \\
\text { pensar, criar e } \\
\text { proporcionar espaços } \\
\text { de reflexões sobre a } \\
\text { "prática de ensino- } \\
\text { aprendizagem". }\end{array}$ & & - \\
\hline
\end{tabular}

Em relação ao tema "Desenvolvimento pessoal e organizacional", tomou-se como referência o método Paideia apresentado por Campos (2006), que consiste na ampliação da capacidade de analisar e de intervir sobre o mundo. E nessa temática foram constatadas quatro narrativas correspondentes. 
Quadro 15 - Correlação entre concepções de educação e o tema "Desenvolvimento pessoal e organizacional"

\begin{tabular}{|c|c|c|c|}
\hline Narrativas & $\begin{array}{c}\text { Concepção de } \\
\text { educação destacada } \\
\text { no texto }\end{array}$ & Temas & $\begin{array}{c}\text { Inferências a partir de } \\
\text { trechos das narrativas que } \\
\text { correspondem a } \\
\text { concepções de educação }\end{array}$ \\
\hline $\begin{array}{l}\text { "A importância da } \\
\text { educação para o } \\
\text { desenvolvimento } \\
\text { pessoal e } \\
\text { organizacional no } \\
\text { serviço público" }\end{array}$ & $\begin{array}{l}{[\ldots] \text { educação para o }} \\
\text { desenvolvimento } \\
\text { pessoal e } \\
\text { organizacional }[\ldots]\end{array}$ & \multirow{4}{*}{$\begin{array}{c}\text { DESENVOLVIMENTO } \\
\text { PESSOAL E } \\
\text { ORGANIZACIONAL }\end{array}$} & \\
\hline $\begin{array}{l}\text { "Educação } \\
\text { Permanente em } \\
\text { Saúde: uma } \\
\text { ferramenta para a } \\
\text { formação" }\end{array}$ & $\begin{array}{l}\text { [...] EPS como política } \\
\text { que orienta a formação } \\
\text { e a qualificação dos } \\
\text { trabalhadores [...] }\end{array}$ & & - \\
\hline $\begin{array}{l}\text { "Elaboração de } \\
\text { material } \\
\text { instrucional de } \\
\text { auditoria para } \\
\text { qualificação dos } \\
\text { profissionais do } \\
\text { Sistema Nacional } \\
\text { de Auditoria do } \\
\text { SUS" }\end{array}$ & $\begin{array}{l}\text { "Os cursos de formação } \\
\text { são componentes de } \\
\text { processos de educação } \\
\text { continuada. O processo } \\
\text { de preparação do } \\
\text { material para esses } \\
\text { cursos se constituiu em } \\
\text { momentos de educação } \\
\text { permanente". }\end{array}$ & & $\begin{array}{l}\text { Destaca elementos } \\
\text { correlacionados à EPS } \\
\text { como reflexão sobre a } \\
\text { prática, tomar como ponto } \\
\text { de partida o conhecimento } \\
\text { cotidiano do trabalho... }\end{array}$ \\
\hline $\begin{array}{l}\text { "Encantos da roda } \\
\text { e vivências da } \\
\text { estratégia } \\
\text { brasileirinhas e } \\
\text { brasileirinhos } \\
\text { saudáveis" }\end{array}$ & $\begin{array}{l}\text { "Na Educação } \\
\text { Permanente em Saúde, } \\
\text { a ação de formação- } \\
\text { intervenção, a utilização } \\
\text { da cartografia como } \\
\text { método, a noção de } \\
\text { grupalidade como } \\
\text { dispositivo e a } \\
\text { dimensão ética do } \\
\text { cuidado resultaram em } \\
\text { transformações } \\
\text { positivas, com melhor } \\
\text { compreensão da } \\
\text { subjetividade do } \\
\text { trabalho vivo em saúde, } \\
\text { que são pontos fortes } \\
\text { para viabilizar um } \\
\text { trabalho mais } \\
\text { qualitativo no âmbito do } \\
\text { SUS, o saber cuidar." }\end{array}$ & & - \\
\hline
\end{tabular}

No que se refere ao tema "Problematização", também foram levados em consideração os conceitos trazidos pelas normas da Pneps, as quais orientam que os processos educativos devem partir de problemas enfrentados na realidade, envolvendo diferentes atores que atuam na área da saúde. Sobre esse tema, Johann (2009) fala de uma busca incessante e de partilha de novas descobertas. $E$ 
Freire (1987) destaca a metodologia da problematização como elemento que favorece a reflexão e o diálogo entre educadores e educandos.

A metodologia problematizadora é mais do que uma abordagem educativa, porque ela é uma postura educacional crítica sobre os elementos da realidade vivida pelos sujeitos do processo, além de considerar que os problemas do cotidiano são janelas de oportunidades para a construção de hipóteses que busquem soluções factíveis. (BRASIL, 2014, p.11)

Em relação ao tema "Problematização", foram identificadas três narrativas correspondentes, sendo que uma das narrativas, sob o título "Videoconferências da Rede Cegonha: uma estratégia de Educação Permanente em Saúde no SUS”, traz a concepção de educação relacionada tanto à "Problematização" quanto à "Reflexão sobre a prática", conforme detalhado no Quadro 16. Importante destacar que, mesmo que não tenham declarado expressamente as concepções de educação, foi possível relacionar as narrativas ao tema a partir de inferências da pesquisadora quanto a alguns trechos das narrativas.

Quadro 16 - Correlação entre concepções de educação e o tema "Problematização"

\begin{tabular}{|c|c|c|c|}
\hline Narrativas & $\begin{array}{l}\text { Concepção de } \\
\text { educação destacada } \\
\text { no texto }\end{array}$ & Temas & $\begin{array}{l}\text { Inferências a partir de } \\
\text { trechos das narrativas } \\
\text { que correspondem a } \\
\text { concepções de educação }\end{array}$ \\
\hline $\begin{array}{l}\text { "Avaliação do } \\
\text { processo de } \\
\text { trabalho: atuação } \\
\text { da área técnica de } \\
\text { alimentação e } \\
\text { nutrição na } \\
\text { vigilância alimentar } \\
\text { e nutricional do } \\
\text { Dsei Pernambuco" }\end{array}$ & $\begin{array}{l}\text { NÃO DECLARADA } \\
\text { EXPRESSAMENTE }\end{array}$ & PROBLEMATIZAÇÃO & $\begin{array}{l}\text { Destaca que a ação } \\
\text { desenvolvida é } \\
\text { fundamentada na } \\
\text { problematização e na } \\
\text { dialética apresentadas na } \\
\text { obra de Paulo Freire. }\end{array}$ \\
\hline $\begin{array}{l}\text { "Educação } \\
\text { permanente em } \\
\text { cuidados } \\
\text { paliativos: relato } \\
\text { de experiência no } \\
\text { Instituto Nacional } \\
\text { de Câncer José } \\
\text { Alencar Gomes da } \\
\text { Silva" }\end{array}$ & $\begin{array}{l}\text { NÃO DECLARADA } \\
\text { EXPRESSAMENTE }\end{array}$ & PROBLEMATIZAÇÃO & $\begin{array}{l}\text { Apresenta aspectos } \\
\text { correlacionados à EPS. }\end{array}$ \\
\hline $\begin{array}{l}\text { "Videoconferências } \\
\text { da Rede Cegonha: } \\
\text { uma estratégia de } \\
\text { Educação } \\
\text { Permanente em } \\
\text { Saúde no SUS" }\end{array}$ & $\begin{array}{l}\text { NÃO DECLARADA } \\
\text { EXPRESSAMENTE }\end{array}$ & $\begin{array}{c}\text { REFLEXÃO SOBRE A } \\
\text { PRÁTICA } \\
\text { e } \\
\text { PROBLEMATIZAÇÃO }\end{array}$ & $\begin{array}{l}\text { Destaca alguns termos } \\
\text { correlacionados à EPS, } \\
\text { como reflexão das práticas } \\
\text { a partir da problematização } \\
\text { de vivências concretas e } \\
\text { possibilidades de } \\
\text { construção de soluções e } \\
\text { estratégias. }\end{array}$ \\
\hline
\end{tabular}


O tema "Aprendizagem significativa" foi escolhido com base no conceito também trazido pela norma que instituiu a Pneps, que trata o referido tema como um processo de aprendizagem que propicia a construção de conhecimentos a partir de saberes prévios dos sujeitos articulados aos problemas vivenciados no trabalho. Merhy et. al (2006) também trata da "Aprendizagem significativa" como o diálogo com os saberes e experiências que as pessoas trazem consigo que produz sentido. Duas narrativas foram identificadas com essa temática, conforme destacado no Quadro 17.

Quadro 17 - Correlação entre concepções de educação e o tema "Aprendizagem significativa"

\begin{tabular}{|c|c|c|}
\hline Narrativas & $\begin{array}{c}\text { Concepção de educação destacada } \\
\text { no texto }\end{array}$ & Temas \\
\hline $\begin{array}{l}\text { "A tecitura da I Mostra } \\
\text { Nacional de Educação } \\
\text { Permanente - } \\
\text { reconhecendo as práticas } \\
\text { dos trabalhadores do } \\
\text { Ministério da Saúde" }\end{array}$ & $\begin{array}{l}\text { "[...] práticas educacionais que } \\
\text { promovam a aprendizagem significativa } \\
\text { dos sujeitos." }\end{array}$ & $\begin{array}{l}\text { APRENDIZAGEM } \\
\text { SIGNIFICATIVA }\end{array}$ \\
\hline $\begin{array}{l}\text { "Roteiro de análise de } \\
\text { convênios do Siconv" }\end{array}$ & $\begin{array}{l}\text { "[...] somente a partir da realidade local e } \\
\text { da singularidade dos atores é possível } \\
\text { construir processos que façam sentido e } \\
\text { que sejam efetivamente apropriados } \\
\text { pelos trabalhadores em seu cotidiano." } \\
\text { "[...] as soluções em EPS têm potencial } \\
\text { para transformar os processos de } \\
\text { trabalho a partir da compreensão das } \\
\text { limitações e potencialidades dos próprios } \\
\text { sujeitos envolvidos nos processos, e da } \\
\text { busca da construção coletiva de } \\
\text { alternativas, desenvolvendo, na prática, } \\
\text { mais habilidades e autonomia dos } \\
\text { sujeitos." }\end{array}$ & $\begin{array}{c}\text { APRENDIZAGEM } \\
\text { SIGNIFICATIVA } \\
\text { TRANSFORMAÇÃO DE } \\
\text { PRÁTICAS } \\
\text { COMPARTILHAMENTO DE } \\
\text { INFORMAÇÕES E } \\
\text { SABERES }\end{array}$ \\
\hline
\end{tabular}

No tema "Valorização de saberes prévios", foram considerados os saberes populares e adotada a concepção trazida por Feuerwerker (2014). Sobre esses saberes, a autora considera aqueles adquiridos sistematicamente por meio de processos educativos formais ou por meio de sua experiência cotidiana. Nessa temática, foram identificadas duas narrativas, conforme é possível constatar no Quadro 18. 
Quadro 18 - Correlação entre concepções de educação e o tema "Valorização de saberes prévios" e outros temas correlatos

\begin{tabular}{|c|c|c|c|}
\hline Narrativas & $\begin{array}{c}\text { Concepção de } \\
\text { educação destacada } \\
\text { no texto }\end{array}$ & Temas & $\begin{array}{l}\text { Inferências a partir de } \\
\text { trechos das narrativas } \\
\text { que correspondem a } \\
\text { concepcões de educacão }\end{array}$ \\
\hline $\begin{array}{l}\text { "A linguagem } \\
\text { teatral como meio } \\
\text { de integração, } \\
\text { motivação e } \\
\text { promoção de } \\
\text { ações de } \\
\text { Educação } \\
\text { Permanente em } \\
\text { Saúde no } \\
\text { NEMS/ES" }\end{array}$ & $\begin{array}{l}\text { NÃO DECLARADA } \\
\text { EXPRESSAMENTE }\end{array}$ & $\begin{array}{c}\text { COMPARTILHAMENTO } \\
\text { DE INFORMAÇÕES E } \\
\text { SABERES } \\
\text { VALORIZAÇÃO DE } \\
\text { SABERES PRÉVIOS } \\
\text { TRANSFORMAÇÃO DE } \\
\text { PRÁTICAS }\end{array}$ & $\begin{array}{l}\text { Destaca alguns termos } \\
\text { correlacionados à EPS, } \\
\text { como: mudanças nas } \\
\text { relações de trabalho; } \\
\text { valorização de } \\
\text { conhecimentos dos } \\
\text { servidores a partir de suas } \\
\text { realidades; gestão } \\
\text { participativa; trabalhadores } \\
\text { assumindo o } \\
\text { protagonismo; gestão } \\
\text { compartilhada. }\end{array}$ \\
\hline $\begin{array}{l}\text { "Aprender de um } \\
\text { modo diferente } \\
\text { pode mesmo fazer } \\
\text { a diferença? } \\
\text { Novas reflexões" }\end{array}$ & $\begin{array}{l}\text { NÃO DECLARADA } \\
\text { EXPRESSAMENTE }\end{array}$ & $\begin{array}{c}\text { COMPARTILHAMENTO } \\
\text { DE INFORMAÇÕES E } \\
\text { SABERES/ } \\
\text { VALORIZAÇÃO DE } \\
\text { SABERES PRÉVIOS }\end{array}$ & $\begin{array}{l}\text { Fomentar a troca de } \\
\text { experiências dentro das } \\
\text { equipes, valorizar o saber } \\
\text { que estas possuem e, } \\
\text { ainda, enfatizar uma } \\
\text { superação da } \\
\text { fragmentação nos } \\
\text { processos de trabalho, } \\
\text { inclusive a fragmentação } \\
\text { entre a gestão e a } \\
\text { execução do trabalho. }\end{array}$ \\
\hline
\end{tabular}

Sobre "Aprendizagem em serviço", foram considerados os conceitos trazidos pelas normas que tratam sobre a Pneps, que a define como uma ação na qual o aprender e o ensinar se incorporam ao quotidiano das organizações e ao trabalho. Apenas uma narrativa foi identificada com essa temática, conforme disposto no quadro abaixo.

Quadro 19 - Correlação entre concepções de educação e o tema "Aprendizagem em serviço"

\begin{tabular}{|c|c|c|c|}
\hline Narrativas & $\begin{array}{c}\text { Concepção de } \\
\text { educação destacada } \\
\text { no texto }\end{array}$ & Temas & $\begin{array}{l}\text { Inferências a partir de } \\
\text { trechos das narrativas } \\
\text { que correspondem a } \\
\text { concepções de educação }\end{array}$ \\
\hline $\begin{array}{l}\text { "EpiSUS: uma } \\
\text { experiência bem- } \\
\text { sucedida no } \\
\text { atendimento às } \\
\text { emergências em } \\
\text { saúde pública" }\end{array}$ & $\begin{array}{l}\text { NÃO DECLARADA } \\
\text { EXPRESSAMENTE }\end{array}$ & $\begin{array}{c}\text { APRENDIZAGEM EM } \\
\text { SERVIÇO }\end{array}$ & $\begin{array}{l}\text { Destaca expressões } \\
\text { correlacionadas à EPS, } \\
\text { como "aprender fazendo". }\end{array}$ \\
\hline
\end{tabular}

Os temas "Transformação de Práticas", "Analise do cotidiano do trabalho" e "Valorização e humanização dos profissionais" foram criados a partir do que trazem de informações as narrativas publicadas na Coletânea. 
Nove narrativas foram identificadas com o tema "Transformação de Práticas". No Quadro 20, estão duas narrativas correspondentes ao tema, que foram escolhidas pela pesquisadora por apresentarem informações em todos os campos necessários para análise.

Quadro 20 - Correlação entre concepções de educação e o tema "Transformação de práticas"

\begin{tabular}{|c|c|c|}
\hline Narrativas & $\begin{array}{l}\text { Concepção de educação } \\
\text { destacada no texto }\end{array}$ & Temas \\
\hline $\begin{array}{l}\text { "Educação Permanente } \\
\text { em Saúde dos } \\
\text { profissionais participantes } \\
\text { do programa Mais Médicos } \\
\text { para o Brasil no Tocantins: } \\
\text { uma estratégia } \\
\text { imprescindível para o } \\
\text { fortalecimento da atenção } \\
\text { primária no estado" }\end{array}$ & $\begin{array}{l}\text { "[...] processos de ensino- } \\
\text { aprendizagem condizentes com a } \\
\text { realidade e demandas do território } \\
{[\ldots] "}\end{array}$ & $\begin{array}{c}\text { TRANSFORMAÇÃO DE } \\
\text { PRÁTICAS }\end{array}$ \\
\hline $\begin{array}{l}\text { "Oficina itinerante de } \\
\text { gestão de pessoas" }\end{array}$ & $\begin{array}{l}\text { "[...] EPS - dispositivo estratégico } \\
\text { de transformação de gestão no } \\
\text { SUS [...]" }\end{array}$ & \\
\hline
\end{tabular}

Segue quadro com as duas narrativas que se relacionam ao tema "Análise do cotidiano do trabalho".

Quadro 21 - Correlação entre concepções de educação e o tema "Análise do cotidiano do trabalho"

\begin{tabular}{|c|c|c|}
\hline Narrativas & $\begin{array}{c}\text { Concepção de educação destacada no } \\
\text { texto }\end{array}$ & Temas \\
\hline $\begin{array}{l}\text { “A Educação Permanente } \\
\text { em Saúde como } \\
\text { ferramenta de trabalho na } \\
\text { clínica de neurocirurgia” }\end{array}$ & $\begin{array}{l}\text { "No processo educativo da Educação } \\
\text { Permanente em Saúde, o cotidiano do } \\
\text { trabalho encontra-se em constante } \\
\text { análise, buscando-se avaliação e reflexão } \\
\text { em espaços coletivos dos atos } \\
\text { produzidos. Nesse processo está inserida } \\
\text { a educação em serviço que coloca a } \\
\text { pertinência dos conteúdos, instrumentos e } \\
\text { recursos para a qualificação técnica } \\
\text { submetida a um projeto de mudanças } \\
\text { institucionais ou de mudança da } \\
\text { orientação das ações prestadas." }\end{array}$ & \multirow{2}{*}{$\begin{array}{c}\text { ANÁLISE DO COTIDIANO } \\
\text { DO TRABALHO }\end{array}$} \\
\hline $\begin{array}{l}\text { "Aperfeiçoamento sobre as } \\
\text { atribuições e competências } \\
\text { dos AIS, Aisans e } \\
\text { profissionais do Dsei } \\
\text { Yanomami" }\end{array}$ & $\begin{array}{l}\text { "A Educação Permanente em Saúde parte } \\
\text { do princípio de que a condição } \\
\text { indispensável para uma pessoa ou uma } \\
\text { organização decidir mudar ou incorporar } \\
\text { novos elementos à sua prática e a seus } \\
\text { conceitos é a detecção e contato com os } \\
\text { desconfortos experimentados no cotidiano } \\
\text { do trabalho, a percepção de que a } \\
\text { maneira vigente de fazer ou de pensar é } \\
\text { insuficiente ou insatisfatória para dar conta } \\
\text { dos desafios do trabalho." }\end{array}$ & \\
\hline
\end{tabular}


Por fim, temos apenas uma narrativa que corresponde ao tema "Valorização e humanização dos profissionais", conforme destaque no Quadro 22.

Quadro 22 - Correlação entre concepções de educação e o tema "Valorização e humanização dos profissionais"

\begin{tabular}{|c|c|c|c|}
\hline Narrativas & $\begin{array}{l}\text { Concepção de } \\
\text { educação destacada } \\
\text { no texto }\end{array}$ & Temas & $\begin{array}{l}\text { Inferências a partir de } \\
\text { trechos das narrativas } \\
\text { que correspondem a } \\
\text { concepções de educação }\end{array}$ \\
\hline $\begin{array}{l}\text { "A arte na } \\
\text { Enfermagem } \\
\text { como estratégia } \\
\text { de transformação } \\
\text { das relações de } \\
\text { trabalho: oficina } \\
\text { do cuidador" }\end{array}$ & $\begin{array}{l}\text { NÃO DECLARADA } \\
\text { EXPRESSAMENTE }\end{array}$ & $\begin{array}{l}\text { VALORIZAČÃO E } \\
\text { HUMANIZAÇAOO DOS } \\
\text { PROFISSIONAIS }\end{array}$ & $\begin{array}{l}\text { Destaca aspectos como } \\
\text { valorização e humanização } \\
\text { dos profissionais de } \\
\text { enfermagem. }\end{array}$ \\
\hline
\end{tabular}

Independentemente da concepção de educação apresentada nas narrativas, não cabe, neste trabalho, fazer um julgamento do que seria um processo de Educação Permanente ou não, uma vez que um dos propósitos da Mostra, conforme descrito na Coletânea, era reconhecer as ações de EPS que acontecem no país no nível federal do SUS, cooperar com elas e dar-Ihes visibilidade, a fim de fortalecer a EP como norteadora de novas práticas que orientam a reflexão sobre os processos de trabalho e a construção de processos de aprendizagem colaborativa e significativa, oportunizando ações coletivas de desenvolvimento aos trabalhadores, a partir dos principais desafios identificados pelas equipes no cotidiano do trabalho.

\subsection{Quais mudanças podem ser identificadas nos processos de trabalho ou

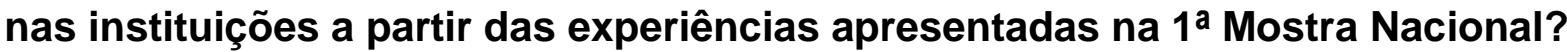

Foi possível identificar as principais mudanças ocorridas nas unidades do Ministério da Saúde com experiências apresentadas na $1^{\text {a }}$ Mostra Nacional a partir das declarações realizadas em 33 narrativas. Analisando o método, o(s) objetivo(s) das ações realizadas e as mudanças ocorridas, foi possível agrupá-las de acordo com os temas/categorias destacados abaixo:

a) qualificação de processos de trabalho (mudanças institucionais e transformações positivas no trabalho);

b) integração entre equipes;

c) aprendizagem no trabalho; e 
d) satisfação do usuário.

Assim, temos a Tabela 3.

Tabela 3 - Quantitativo de narrativas segundo temas relacionados às mudanças ocorridas a partir das experiências relatadas

\begin{tabular}{l|c}
\hline \multicolumn{1}{|c|}{ TEMAS RELACIONADOS ÁS MUDANÇAS IDENTIFICADAS } & TOTAL \\
\hline - Qualificação de processos de trabalho & $\mathbf{2 0}$ \\
- Integração entre equipes & $\mathbf{1 7}$ \\
- Aprendizagem no trabalho & 3 \\
- Satisfação do usuário & 1 \\
- Não foi possível identificar & $\mathbf{2 3}$ \\
\hline
\end{tabular}

A partir da Tabela 3, percebe-se que o somatório de narrativas supera o total de 56 relatos analisados, conforme destacado na metodologia deste trabalho. Isso ocorreu porque foram constatados mais de um tema em algumas narrativas, como é o caso de narrativas relacionadas aos conjuntos de temas/categorias, conforme a Tabela 4.

Tabela 4 - Quantitativo de narrativas, segundo conjunto de temas relacionados às mudanças ocorridas a partir das experiências relatadas

\begin{tabular}{c|c}
\hline CONJUNTO DE TEMAS APRESENTADOS NUMA MESMA NARRATIVA & TOTAL \\
\hline - Integração entre equipes / Satisfação do usuário & 1 \\
- Integração entre equipes / Qualificação de processos de trabalho & $\mathbf{5}$ \\
- Integração entre equipes / Qualificação de processos de trabalho/ & $\mathbf{3}$ \\
- Inprendizagem no trabalho & 1 \\
- Qualificação de processos de trabalho / Aprendizagem no trabalho & 1 \\
\hline
\end{tabular}

Em 23 experiências publicadas na Coletânea de Narrativas não foi possível identificar as mudanças ocorridas. Na sequência, temos que vinte narrativas apresentaram como principal mudança a qualificação de processos de trabalho, conforme pode-se constatar no Quadro 23 , com três narrativas para exemplificar essa correlação entre método, objetivo(s) das ações realizadas e as principais mudanças ocorridas a partir da experiência relatada. No tema "Qualificação de processos de trabalho", foram consideradas ações que desencadearam mudanças institucionais e transformações positivas no trabalho, conforme informações contidas 
nas narrativas analisadas. As narrativas presentes no Quadro 23 foram escolhidas por apresentarem informações em todos os campos necessários para análise.

Quadro 23 - Correlação entre métodos, objetivos e as principais mudanças ocorridas a partir da experiência relatada (Qualificação de processos de trabalho)

\begin{tabular}{|c|c|c|c|c|}
\hline Narrativas & Método & $\begin{array}{c}\text { Objetivo(s) das } \\
\text { Ações }\end{array}$ & $\begin{array}{l}\text { Mudanças } \\
\text { ocorridas }\end{array}$ & $\begin{array}{c}\text { Temas } \\
\text { relacionados às } \\
\text { mudanças }\end{array}$ \\
\hline $\begin{array}{l}\text { "A importância da } \\
\text { educação para o } \\
\text { desenvolvimento } \\
\text { pessoal e } \\
\text { organizacional no } \\
\text { serviço público" }\end{array}$ & $\begin{array}{l}\text { Realização de } \\
\text { pesquisa de } \\
\text { campo com } \\
\text { utilização de } \\
\text { questionário } \\
\text { como } \\
\text { instrumento } \\
\text { para captação } \\
\text { de informações. } \\
\text { Também foi } \\
\text { realizada } \\
\text { pesquisa } \\
\text { bibliográfica } \\
\text { para elaboração } \\
\text { do questionário } \\
\text { e interpretação } \\
\text { dos dados. }\end{array}$ & $\begin{array}{l}\text { Verificar a } \\
\text { importância da } \\
\text { educação para o } \\
\text { desenvolvimento } \\
\text { pessoal e } \\
\text { organizacional do } \\
\text { Into, a partir da } \\
\text { percepção dos } \\
\text { agentes } \\
\text { administrativos } \\
\text { sobre os cursos } \\
\text { nos quais } \\
\text { participaram no ano } \\
\text { de } 2010 .\end{array}$ & $\begin{array}{l}\text { Segundo a narrativa, } \\
\text { houve avanços em } \\
\text { programas de } \\
\text { educação no } \\
\text { Instituto, aumento de } \\
\text { produtividade, } \\
\text { elevação dos } \\
\text { padrões de } \\
\text { qualidade, } \\
\text { diminuição de erros } \\
\text { e redução de } \\
\text { retrabalho. No } \\
\text { entanto, não fica } \\
\text { claro como esses } \\
\text { dados foram } \\
\text { aferidos. }\end{array}$ & \multirow{3}{*}{$\begin{array}{c}\text { QUALIFICAÇÃO } \\
\text { DE } \\
\text { PROCESSOS } \\
\text { DE TRABALHO }\end{array}$} \\
\hline $\begin{array}{l}\text { "Encantos da roda } \\
\text { e vivências da } \\
\text { estratégia } \\
\text { brasileirinhas e } \\
\text { brasileirinhos } \\
\text { saudáveis" }\end{array}$ & $\begin{array}{l}\text { A cartografia foi } \\
\text { utilizada como } \\
\text { método. }\end{array}$ & $\begin{array}{l}\text { Fortalecimento de } \\
\text { ações e políticas } \\
\text { públicas voltadas } \\
\text { para a primeira } \\
\text { infância. }\end{array}$ & $\begin{array}{l}\text { Transformações } \\
\text { positivas, com } \\
\text { melhor compreensão } \\
\text { da subjetividade do } \\
\text { trabalho vivo em } \\
\text { saúde, que são } \\
\text { pontos fortes para } \\
\text { viabilizar um trabalho } \\
\text { mais qualitativo no } \\
\text { âmbito do SUS. }\end{array}$ & \\
\hline $\begin{array}{l}\text { "Gerenciamento } \\
\text { das filas cirúrgicas } \\
\text { em um dos } \\
\text { hospitais federais } \\
\text { localizado no Rio } \\
\text { de Janeiro: relato } \\
\text { de experiência" }\end{array}$ & $\begin{array}{l}\text { Valorização e } \\
\text { utilização das } \\
\text { experiências } \\
\text { dos profissionais } \\
\text { como potencial } \\
\text { criativo. }\end{array}$ & $\begin{array}{l}\text { Apresentar um } \\
\text { plano de ação para } \\
\text { organizar e realizar } \\
\text { cirurgias dos } \\
\text { pacientes inscritos } \\
\text { nas filas, conforme } \\
\text { prazos e } \\
\text { formalidade } \\
\text { descritos na ação } \\
\text { judicial } \\
\text { apresentada à } \\
\text { União, ao estado e } \\
\text { ao município do Rio } \\
\text { de Janeiro. } \\
\end{array}$ & $\begin{array}{l}\text { A ação possibilitou } \\
\text { as mudanças e a } \\
\text { transformação nas } \\
\text { práticas profissionais } \\
\text { dos trabalhadores do } \\
\text { Hospital Federal de } \\
\text { Bonsucesso. }\end{array}$ & \\
\hline
\end{tabular}

"Integração entre equipes" foi a segunda maior mudança constatada a partir dos relatos das experiências analisadas. O referido tema pôde ser identificado em dezessete narrativas. A seguir, no Quadro 24, são apresentadas três narrativas que exemplificam essa correlação entre método, objetivos e mudanças ocorridas 
relacionadas ao tema "Integração entre equipes". Essas três narrativas foram escolhidas pela pesquisadora por apresentarem informações em todos os campos necessários para análise.

Quadro 24 - Correlação entre métodos, objetivos e as principais mudanças ocorridas a partir da experiência relatada (Integração entre equipes)

\begin{tabular}{|c|c|c|c|c|}
\hline Narrativas & Método & $\begin{array}{l}\text { Objetivo(s) das } \\
\text { ações }\end{array}$ & $\begin{array}{l}\text { Mudanças } \\
\text { ocorridas }\end{array}$ & $\begin{array}{c}\text { Temas } \\
\text { relacionados } \\
\text { às mudanças }\end{array}$ \\
\hline $\begin{array}{l}\text { "Educação } \\
\text { permanente em } \\
\text { cuidados } \\
\text { paliativos: relato } \\
\text { de experiência no } \\
\text { Instituto Nacional } \\
\text { de Câncer José } \\
\text { Alencar Gomes da } \\
\text { Silva" }\end{array}$ & $\begin{array}{l}\text { Várias caixas de } \\
\text { sugestões foram } \\
\text { disponibilizadas } \\
\text { em cada setor do } \\
\text { Hospital. Em } \\
\text { seguida, foi } \\
\text { realizada uma } \\
\text { reunião para } \\
\text { debater as } \\
\text { propostas. }\end{array}$ & $\begin{array}{l}\text { Promover a reflexão } \\
\text { sobre os problemas } \\
\text { e ir até as equipes } \\
\text { para saber o que } \\
\text { elas desejavam ou } \\
\text { esperavam de EPS. }\end{array}$ & $\begin{array}{l}\text { Constatou-se maior } \\
\text { interação entre as } \\
\text { equipes. }\end{array}$ & \multirow{3}{*}{$\begin{array}{c}\text { INTEGRAÇÃO } \\
\text { ENTRE } \\
\text { EQUIPES }\end{array}$} \\
\hline $\begin{array}{l}\text { "Gestão interna do } \\
\text { saber: uma } \\
\text { estratégia de } \\
\text { capacitação em } \\
\text { reanimação" }\end{array}$ & $\begin{array}{l}\text { O processo } \\
\text { pedagógico foi, } \\
\text { inicialmente, } \\
\text { oferecido em } \\
\text { sala de aula da } \\
\text { educacaão } \\
\text { continuada, com } \\
\text { ambiente } \\
\text { simulado e apoio } \\
\text { de outra área. }\end{array}$ & $\begin{array}{l}\text { Capacitação em } \\
\text { reanimação } \\
\text { cardiopulmonar. }\end{array}$ & $\begin{array}{l}\text { Integração com } \\
\text { trocas de } \\
\text { experiências entre } \\
\text { os participantes, } \\
\text { potenciais } \\
\text { educadores e } \\
\text { multiplicadores em } \\
\text { áreas diversas; } \\
\text { abertura de canal de } \\
\text { comunicação entre } \\
\text { os representantes } \\
\text { dos serviços e o } \\
\text { serviço de educação } \\
\text { continuada; evidente } \\
\text { melhora na } \\
\text { apropriação dos } \\
\text { conceitos teóricos e } \\
\text { das ações práticas; } \\
\text { reformulação de } \\
\text { ações da prática a } \\
\text { partir dos erros } \\
\text { identificados pelos } \\
\text { próprios envolvidos; } \\
\text { desenvolvimento de } \\
\text { novo olhar dos } \\
\text { trabalhadores sobre } \\
\text { seus próprios } \\
\text { cenários de prática. }\end{array}$ & \\
\hline $\begin{array}{l}\text { "I Semana de } \\
\text { promoção à saúde } \\
\text { e segurança do } \\
\text { trabalhador de } \\
\text { Enfermagem: } \\
\text { integração de } \\
\text { serviços do } \\
\text { Hospital Federal } \\
\text { do Andaraí para a } \\
\text { qualidade de vida }\end{array}$ & $\begin{array}{l}\text { Constituíram-se } \\
\text { três mesas } \\
\text { redondas, nas } \\
\text { quais foram } \\
\text { discutidos temas } \\
\text { relacionados à } \\
\text { saúde do } \\
\text { indivíduo e do } \\
\text { trabalhador. }\end{array}$ & $\begin{array}{l}\text { Integração de } \\
\text { serviços do Hospital } \\
\text { Federal do Andaraí } \\
\text { para a qualidade de } \\
\text { vida no trabalho. }\end{array}$ & $\begin{array}{l}\text { Integração } \\
\text { multiprofissional, } \\
\text { desenvolvimento de } \\
\text { atividade física, } \\
\text { criação de parcerias, } \\
\text { (estreitando laços } \\
\text { entre os } \\
\text { profissionais) e a } \\
\text { orientação dos } \\
\text { trabalhadores de }\end{array}$ & \\
\hline
\end{tabular}


continuação

\begin{tabular}{|c|c|c|c|c|}
\hline Narrativas & Método & $\begin{array}{c}\text { Objetivo(s) das } \\
\text { ações }\end{array}$ & $\begin{array}{l}\text { Mudanças } \\
\text { ocorridas }\end{array}$ & $\begin{array}{c}\text { Temas } \\
\text { relacionados } \\
\text { às mudanças }\end{array}$ \\
\hline no trabalho" & & & $\begin{array}{l}\text { Enfermagem sobre a } \\
\text { importância da } \\
\text { conservação e da } \\
\text { proteção de sua } \\
\text { saúde, com trabalho } \\
\text { voltado para a } \\
\text { sensibilização sobre } \\
\text { qualidade de vida, } \\
\text { prevenção de } \\
\text { doenças e de } \\
\text { acidentes no } \\
\text { ambiente de } \\
\text { trabalho, sob } \\
\text { diferentes ópticas. }\end{array}$ & \\
\hline
\end{tabular}

Três narrativas apresentaram como principal mudança a aprendizagem no trabalho, conforme é possível conferir no quadro abaixo.

Quadro 25 - Correlação entre métodos, objetivos e as principais mudanças ocorridas a partir da experiência relatada (Aprendizagem no trabalho)

\begin{tabular}{|c|c|c|c|c|}
\hline Narrativas & Método & $\begin{array}{l}\text { Objetivo(s) das } \\
\text { ações }\end{array}$ & $\begin{array}{l}\text { Mudanças } \\
\text { ocorridas }\end{array}$ & $\begin{array}{c}\text { Temas } \\
\text { relacionados às } \\
\text { mudanças }\end{array}$ \\
\hline $\begin{array}{l}\text { "Curso de } \\
\text { educação a } \\
\text { distância Saber } \\
\text { saúde: prevenção } \\
\text { do tabagismo e de } \\
\text { outros fatores de } \\
\text { risco para o } \\
\text { desenvolvimento } \\
\text { de doenças } \\
\text { crônicas não } \\
\text { transmissíveis" }\end{array}$ & $\begin{array}{l}\text { Por meio do } \\
\text { curso a } \\
\text { distância, os } \\
\text { profissionais de } \\
\text { saúde e da } \\
\text { educação } \\
\text { compartilham } \\
\text { conhecimentos } \\
\text { que contribuem } \\
\text { para a } \\
\text { prevenção do } \\
\text { câncer. }\end{array}$ & $\begin{array}{l}\text { Oferecer subsídios } \\
\text { aos profissionais da } \\
\text { Saúde e da } \\
\text { Educação para que } \\
\text { trabalhem, em } \\
\text { escolas, processos } \\
\text { pedagógicos } \\
\text { voltados à } \\
\text { prevenção do } \\
\text { tabagismo e de } \\
\text { outros fatores de } \\
\text { risco para doenças } \\
\text { crônicas não } \\
\text { transmissíveis, } \\
\text { entre elas, o } \\
\text { câncer. }\end{array}$ & $\begin{array}{l}\text { Segundo a } \\
\text { narrativa, foram } \\
\text { formados até a } \\
\text { data de realização } \\
\text { da Mostra, } 1.390 \\
\text { trabalhadores que } \\
\text { indicaram ter sido } \\
\text { o curso } \\
\text { extremamente } \\
\text { relevante para sua } \\
\text { formação pessoal } \\
\text { e profissional. }\end{array}$ & $\begin{array}{l}\text { APRENDIZAGEM } \\
\text { NO TRABALHO }\end{array}$ \\
\hline
\end{tabular}

continua 
continuação

\begin{tabular}{|c|c|c|c|c|}
\hline Narrativas & Método & $\begin{array}{c}\text { Objetivo(s) das } \\
\text { ações }\end{array}$ & $\begin{array}{l}\text { Mudanças } \\
\text { ocorridas }\end{array}$ & $\begin{array}{l}\text { Temas } \\
\text { relacionados às } \\
\text { mudanças }\end{array}$ \\
\hline $\begin{array}{l}\text { "Oficinas } \\
\text { itinerantes sobre a } \\
\text { avaliação de } \\
\text { desempenho no } \\
\text { Inca" }\end{array}$ & Oficinas & $\begin{array}{l}\text { Levar aos } \\
\text { servidores } \\
\text { informações } \\
\text { relevantes } \\
\text { referentes aos } \\
\text { processos e aos } \\
\text { procedimentos } \\
\text { ligados à área de } \\
\text { Gestão de Pessoas } \\
\text { do Inca. }\end{array}$ & $\begin{array}{l}\text { Entre servidores e } \\
\text { gestores foram } \\
\text { atingidos } 65 \% \text { do } \\
\text { quadro de pessoal, } \\
\text { o que corresponde } \\
\text { a } 2.017 \text { pessoas } \\
\text { capacitadas, num } \\
\text { total de } 23 \text { oficinas } \\
\text { e quatro materiais } \\
\text { informativos } \\
\text { específicos. As } \\
\text { oficinas permitiram } \\
\text { à área de Gestão } \\
\text { de Pessoas a } \\
\text { identificação de } \\
\text { carência dos } \\
\text { servidores quanto } \\
\text { às informações } \\
\text { sobre } \\
\text { aposentadoria, } \\
\text { férias etc. }\end{array}$ & \multirow{2}{*}{$\begin{array}{c}\text { APRENDIZAGEM } \\
\text { NO TRABALHO }\end{array}$} \\
\hline $\begin{array}{l}\text { "Prática de } \\
\text { governança na } \\
\text { Hemobrás: } \\
\text { estratégia de } \\
\text { avaliação de } \\
\text { novos } \\
\text { empregados } \\
\text { públicos" }\end{array}$ & $\begin{array}{l}\text { A prática foi } \\
\text { desenvolvida } \\
\text { por várias mãos, } \\
\text { a partir de rodas } \\
\text { de discussão } \\
\text { com os } \\
\text { trabalhadores e } \\
\text { gestores, tendo } \\
\text { a facilitação de } \\
\text { uma empresa de } \\
\text { consultoria. }\end{array}$ & $\begin{array}{l}\text { Qualificar e } \\
\text { desenvolver o } \\
\text { quadro funcional da } \\
\text { Hemobrás e } \\
\text { subsidiar a } \\
\text { efetivação ou não } \\
\text { destes ao final dos } \\
90 \text { dias de } \\
\text { experiência, } \\
\text { conforme preconiza } \\
\text { a Consolidação das } \\
\text { Leis do Trabalho, } \\
\text { além de promover o } \\
\text { desenvolvimento do } \\
\text { empregado e da } \\
\text { equipe por meio de } \\
\text { ações direcionadas } \\
\text { para suas } \\
\text { necessidades e } \\
\text { habilidades a } \\
\text { serem } \\
\text { desenvolvidas ou } \\
\text { qualificadas. }\end{array}$ & $\begin{array}{l}\text { "O produto desse } \\
\text { trabalho foi um } \\
\text { instrumento de } \\
\text { avaliação, com } \\
\text { aceitação e } \\
\text { aplicabilidade por } \\
\text { todos os } \\
\text { envolvidos no } \\
\text { processo." }\end{array}$ & \\
\hline
\end{tabular}

Em relação ao tema "Satisfação do usuário", referente às mudanças ocorridas com o desenvolvimento das ações apresentadas nas narrativas, foi possível identificá-lo claramente apenas em um relato. E, juntamente com esse tema, outro também pôde ser identificado, que é o de integração entre equipes, como é possível comprovar no Quadro 26. 
Quadro 26 - Correlação entre métodos, objetivos e as principais mudanças ocorridas a partir da experiência relatada (Satisfação do usuário/ Integração entre equipes)

\begin{tabular}{|c|c|c|c|c|}
\hline Narrativas & Método & $\begin{array}{c}\text { Objetivo(s) das } \\
\text { ações }\end{array}$ & $\begin{array}{l}\text { Mudanças } \\
\text { ocorridas }\end{array}$ & $\begin{array}{c}\text { Temas } \\
\text { relacionados } \\
\text { às mudanças }\end{array}$ \\
\hline $\begin{array}{l}\text { "A Educação } \\
\text { Permanente em } \\
\text { Saúde como } \\
\text { ferramenta de } \\
\text { trabalho na clínica } \\
\text { de neurocirurgia" }\end{array}$ & $\begin{array}{l}\text { Os temas das } \\
\text { Rodas de } \\
\text { Conversa são } \\
\text { escolhidos com } \\
\text { base nos } \\
\text { diagnósticos dos } \\
\text { pacientes } \\
\text { internados e na } \\
\text { relevância, além } \\
\text { do levantamento } \\
\text { de necessidades } \\
\text { e de conduta. Os } \\
\text { residentes de } \\
\text { enfermagem são } \\
\text { os responsáveis } \\
\text { pelo } \\
\text { direcionamento } \\
\text { dos assuntos. }\end{array}$ & $\begin{array}{l}\text { Criar espaços } \\
\text { coletivos para } \\
\text { discussão, } \\
\text { avaliação e reflexão } \\
\text { dos atos produzidos } \\
\text { no cotidiano; } \\
\text { estimular e facilitar } \\
\text { o processo de } \\
\text { ensino- } \\
\text { aprendizagem; } \\
\text { relacionar o } \\
\text { aprendizado com a } \\
\text { prática assistencial } \\
\text { e buscar melhorias } \\
\text { na qualidade do } \\
\text { serviço prestado ao } \\
\text { usuário, levando-se } \\
\text { em consideração, } \\
\text { nesse processo, as } \\
\text { vivências, os } \\
\text { pensamentos e os } \\
\text { saberes de cada } \\
\text { integrante da } \\
\text { equipe. }\end{array}$ & $\begin{array}{l}\text { Melhora na } \\
\text { qualidade da } \\
\text { assistência prestada } \\
\text { ao usuário a partir } \\
\text { das discussões } \\
\text { sobre a patologia, } \\
\text { suas especificidades } \\
\text { e o planejamento de } \\
\text { ações direcionadas; } \\
\text { segurança e } \\
\text { entusiasmo da } \\
\text { equipe ao prestar } \\
\text { assistência e sentir- } \\
\text { se parte do } \\
\text { processo; satisfação } \\
\text { do usuário em ter } \\
\text { suas necessidades } \\
\text { atendidas e } \\
\text { diminuição de riscos } \\
\text { preveníveis. }\end{array}$ & $\begin{array}{c}\text { SATISFAÇÃO } \\
\text { DO USUARIO } \\
\text { e } \\
\text { INTEGRAÇÃO } \\
\text { ENTRE } \\
\text { EQUIPES }\end{array}$ \\
\hline
\end{tabular}

Todos esses temas relacionados às mudanças ocorridas com a implementação das experiências apresentadas na Mostra confirmam o que Merhy et. al (2006) pensam sobre a educação no trabalho. Para os autores, conforme já afirmado anteriormente, o trabalho funciona como uma escola, portanto nos encontros e nas situações enfrentadas no dia a dia no mundo do trabalho constituise um ato pedagógico. Seguindo com essa visão, Merhy et. al (2006) afirmam que os processos educativos são construídos a partir da realidade dos trabalhadores, de suas concepções e de suas relações de trabalho.

Corroborando o pensamento desses autores, a Pneps traz a definição de EPS que vai ao encontro das mudanças ocorridas a partir das experiências apresentadas na Mostra. Segundo a Política, a EPS parte dos problemas enfrentados na realidade, considera os conhecimentos e experiências das pessoas e baseia-se na aprendizagem significativa e na possibilidade de transformar as práticas profissionais e da organização do trabalho. 


\section{DISCUSSÃO DOS RESULTADOS}

A partir da sistematização e análise das informações coletadas, foi possível identificar que a $1^{\text {a }}$ Mostra Nacional de Educação Permanente em Saúde contou com a participação de trabalhadores de todas as regiões do País, além daqueles que atuam na sede do Ministério da Saúde, em Brasília. As experiências das regiões Sul e Sudeste foram representadas em sua totalidade na Coletânea de Narrativas. Enquanto da região Nordeste, apenas experiências dos estados do Ceará, Paraíba e Bahia foram contempladas na referida publicação. Da região Norte, registram-se apenas as narrativas correspondentes aos estados do Pará e Tocantins.

Dos seis hospitais federais do Rio de Janeiro, parte da estrutura da Administração Direta do Ministério da Saúde, apenas dois não tiveram suas experiências publicadas na Coletânea de Narrativas: Hospital Federal da Lagoa e Hospital Federal de Ipanema. No caso dos Institutos, dois, dos quatro existentes, foram contemplados na publicação: Instituto Nacional de Câncer José Alencar Gomes da Silva (Inca) e o Instituto Nacional de Traumatologia e Ortopedia Jamil Haddad (Into). Em relação às entidades da Administração Indireta, vinculadas ao Ministério da Saúde, apenas duas tiveram suas narrativas publicadas: a Fundação Oswaldo Cruz (Fiocruz) e a Empresa Brasileira de Hemoderivados e Biotecnologia (Hemobrás). E, no caso das unidades localizadas na sede do Ministério da Saúde, em Brasília, apenas uma Secretaria não teve experiência publicada na Coletânea de Narrativas: a Secretaria de Ciência, Tecnologia e Insumos Estratégicos. Esses dados sugerem a formulação de algumas hipóteses, entre as quais a de que as unidades que não foram contempladas com seus relatos na publicação da Coletânea podem ter apresentado experiências na $1^{\text {a }}$ Mostra, no entanto não enviaram seus relatos para publicação. Apesar de haver fragilidades nos registros das participações de representantes das unidades do MS em ações de desenvolvimento de pessoas promovidas pela Coordenação-Geral de Gestão de Pessoas, é possível inferir que as unidades que não foram contempladas na Coletânea são, em sua maioria, as mesmas unidades que também não participam de outras iniciativas ofertadas pela CGESP. 
Seguindo com os resultados da pesquisa, ao correlacionar as ações realizadas com as diretrizes da Pneps, constatou-se que a maior parte das narrativas publicadas na Coletânea da $1^{\text {a }}$ Mostra refere-se à realização de práticas educacionais em espaços coletivos de trabalho. Esse conceito aproxima-se daquele trazido por Saviani (1994), segundo o qual a educação é um processo de trabalho e, também, corrobora o que Merhy et. al (2006) e Gadotti (2005) pensam da educação no trabalho. Para estes autores, o trabalho deve funcionar como uma escola, portanto o ambiente de trabalho deve ser considerado um espaço de aprendizado. Este é também o entendimento trazido pela própria Pneps, que orienta a aprendizagem no trabalho, no qual o aprender e o ensinar devem se incorporar ao quotidiano das organizações e ao trabalho.

Outra diretriz que também se fez presente nas narrativas está relacionada à contribuição para o enfrentamento da fragmentação dos serviços e das ações de saúde. As narrativas que se relacionam com essa diretriz indicam proximidade com a concepção de educação trazida por Ceccim (2005), que orienta um direcionamento desta à transformação das práticas de saúde.

Ressalta-se, nos resultados desta pesquisa, que a diretriz que corresponde à articulação entre a EPS e a gestão de pessoas por competências para a organização das ações de educação no Ministério da Saúde não foi identificada nas narrativas publicadas na Coletânea da $1^{1}$ a Mostra Nacional. Esses dados confirmam o distanciamento entre as ações realizadas no campo da EP com o modelo de gestão de pessoas por competências sugerido pela Política Nacional de Desenvolvimento de Pessoal. ${ }^{7}$ Isso se justifica por não haver, no Ministério da Saúde, um direcionamento para a implementação deste modelo de gestão de pessoas.

Este estudo também revelou que a concepção de educação que se fez mais presente nas narrativas publicadas refere-se ao compartilhamento de informações e saberes. Trinquet (2010) e Schwartz (2010) falam sobre a importância do

\footnotetext{
${ }^{7}$ A Política Nacional de Desenvolvimento de Pessoal foi instituída pelo Decreto no 5.707 , de 23 de fevereiro de 2006, com as seguintes finalidades: "I - melhoria da eficiência, eficácia e qualidade dos serviços públicos prestados ao cidadão; II - desenvolvimento permanente do servidor público; III adequação das competências requeridas dos servidores aos objetivos das instituições, tendo como referência o plano plurianual; IV - divulgação e gerenciamento das ações de capacitação; e V racionalização e efetividade dos gastos com capacitação". (BRASIL, 2006)
} 
compartilhamento de saberes. O primeiro destaca a importância de associar os saberes acadêmicos com os saberes da experiência para compreender e analisar uma situação de trabalho. E, para o segundo, a educação é considerada como a relação entre pessoas marcada por um patrimônio de saberes que preexiste. Nesse contexto, revela-se, ainda, uma proximidade com a concepção trazida por Campos (2006) em relação ao Método Paideia, segundo o qual se pressupõe a existência de espaços de cogestão e compartilhamento de poder para que a educação atinja seu objetivo de ampliar a capacidade de as pessoas analisarem e intervirem sobre o mundo.

Sabe-se, portanto, que a EP é mais que compartilhar informações e saberes, portanto os resultados da análise das narrativas indicam uma visão que pode ser considerada minimalista do que seja EP por parte dos autores das narrativas. No entanto, esse foi o tema mais prevalente nas narrativas no que se refere à concepção de educação. Esse dado pode ser justificado pelo pouco tempo havido para que os trabalhadores da gestão federal do SUS tivessem uma visão mais ampliada da EP enquanto estratégia e política para formação e desenvolvimento dos trabalhadores do Ministério da Saúde. Conforme já mencionado neste estudo, a discussão sobre as diretrizes da Pneps e sobre a própria Política somente se deu a partir de 2012 no âmbito interno do Ministério da Saúde, ou seja, na gestão federal do SUS.

Outra concepção de educação que também se destacou nas narrativas é aquela que considera o trabalho como espaço de aprendizado. Esse resultado sugere uma relação de proximidade entre a diretriz da Pneps mais prevalente nas narrativas (realização de práticas educacionais em espaços coletivos de trabalho) e as concepções de educação trazidas. Ao considerar o trabalho como espaço de aprendizado, parte-se da realidade dos trabalhadores e de suas relações de trabalho. Nesse sentido, não há como deixar de fazer referências a Merhy et. al (2006) e Freire (1987; 1996) e pensar que é preciso haver uma reflexão crítica sobre as práticas para suas transformações. Assim, revelam-se, também, outras duas concepções de educação que se destacam nas narrativas: transformação e reflexão sobre as práticas.

Outro resultado importante da pesquisa diz respeito às mudanças ocorridas a partir das experiências relatadas. A qualificação dos processos de trabalho e a integração entre as equipes foram as mudanças que mais se destacaram nas 
narrativas. No que se refere à qualificação de processos de trabalho, foram consideradas as mudanças institucionais e, também, as transformações positivas no trabalho.

Novamente, percebe-se a inter-relação nos resultados encontrados. A diretriz que corresponde à realização de práticas educacionais em espaços coletivos de trabalho, o compartilhamento de informações e saberes e também o fato de considerar o trabalho como espaço de aprendizado, alinhados com os resultados de mudanças identificados como qualificação dos processos de trabalho e integração entre equipes, indicam que a EP pode ser considerada uma estratégia de gestão no Ministério da Saúde, na medida em que todas as ações apresentadas nas narrativas da $1^{\text {a }}$ Mostra foram consideradas ações de EP.

Os resultados encontrados neste estudo podem também estar associados aos eixos do quadrilátero da formação para a área da saúde proposto por Ceccim e Feuerwerker (2004): ensino, gestão, atenção e controle social. A diretriz considerada a mais prevalente nas narrativas que consiste na realização de práticas educacionais em espaços coletivos de trabalho, bem como a principal concepção de educação identificada, indicam relação com o eixo referente ao ensino. Quanto ao eixo gestão, este pode estar relacionado ao resultado encontrado no que diz respeito às mudanças ocorridas nos processos de trabalho das unidades da gestão federal do SUS. Neste eixo, pode-se destacar a qualificação dos processos de trabalho e, também, a integração entre as equipes. $O$ eixo do controle social pode ser considerado quando as narrativas estão relacionadas à diretriz referente à contribuição para o enfrentamento da fragmentação dos serviços e das ações de saúde. Já em relação ao eixo da atenção, não foi possível identificá-lo nas narrativas. Isso pode ser justificado pelo fato de que a maior parte das narrativas publicadas na Coletânea e que foram objeto deste estudo refere-se a processos de trabalho desenvolvidos com foco na gestão do SUS, e não na assistência direta à população.

Apesar das fragilidades que se apresentam nas unidades da gestão federal do SUS, é possível constatar, pelas narrativas publicadas das experiências apresentadas na $1^{\underline{a}}$ Mostra Nacional de EPS, que as ações realizadas vêm promovendo mudanças no sentido da qualificação dos processos de trabalho, por meio da integração das equipes. $\mathrm{Na}$ maior parte das unidades, há um compartilhamento de informações e saberes, utilizando o trabalho como espaço de 
aprendizado, direcionando as ações para a transformação de práticas, o que corresponde às concepções de EP e, mais fortemente, às diretrizes da Pneps. Esses dados indicam que há reconhecimento e valorização do conhecimento dos trabalhadores em, no mínimo, $26^{8}$ unidades da gestão federal do SUS.

No entanto, permanece, ainda, o desafio de implementar as diretrizes da Pneps na gestão federal do SUS. Uma forma de tentar superá-lo seria continuar fomentando práticas de EP, reconhecendo e cooperando para que possam se tornar visíveis e potentes.

\footnotetext{
${ }^{8}$ Número que corresponde ao total de unidades com relatos publicados na Coletânea de Narrativas da $1^{\text {a }}$ Mostra Nacional de EP, conforme especificado no capítulo "Resultados" desta pesquisa.
} 


\section{CONSIDERAÇÕES FINAIS}

A discussão da Educação Permanente em Saúde (EPS) veio ao encontro das necessidades de aperfeiçoar o processo de planejamento e execução das ações educativas propostas no âmbito interno do Ministério da Saúde. Assim, a 1를 Mostra Nacional de Educação Permanente em Saúde se apresentou como um convite a tornar visíveis as práticas de Educação Permanente (EP) que acontecem na gestão federal do SUS. Não houve classificação das iniciativas. Assim, todos os trabalhos inscritos foram apresentados como iniciativas de educação permanente em saúde. A partir da análise feita nas narrativas e da revisão de literatura acerca do tema, foi possível distinguir as iniciativas e concepções de educação apresentadas relacionando-as a diferentes visões de autores utilizados no referencial teórico deste estudo.

Superando a diferenciação entre concepções de educação, o desafio que se apresenta internamente no Ministério da Saúde é a combinação das estratégias de forma que tragam elementos necessários para o aprimoramento dos processos de trabalho. Dessa forma, os resultados encontrados nesse estudo apontam a necessidade de continuidade de discussão e avanços na implementação das diretrizes da EP. No entanto, sabe-se que a mudança de paradigmas é um processo longo e que requer a construção de novos olhares.

Outro grande desafio é o reconhecimento da EP como estratégia para a formação e o desenvolvimento dos trabalhadores do Ministério da Saúde. Há uma tendência em valorizar apenas o saber acadêmico e atribuir pouco valor ao conhecimento que vem da prática. Há que se levar em consideração também o fato de que nem sempre as organizações estão preparadas para apoiar os processos de aprendizagem no trabalho. Segundo Davini (2009), fatores materiais e simples, como equipamentos e espaço físico adequado, podem ser impeditivos para que se parta do aprendizado para a ação, mas também a própria organização pode não favorecer para a adoção de novos comportamentos e novos arranjos institucionais.

Nesse sentido, a EP deve ser considerada mais do que uma prática de ensino aprendizagem. Ela deve ser reconhecida e valorizada como uma política de educação em saúde, independentemente de mudanças de gestão, pois vem gerando resultados, como os que são apresentados neste trabalho, que apontam o 
investimento no compartilhamento de informações e saberes trazendo como mudanças, ou transformações positivas, a qualificação dos processos de trabalho na gestão federal do Sistema Único de Saúde (SUS) e, também, a integração entre as equipes.

Apesar de se identificarem diferentes concepções de educação nas narrativas da 1a Mostra Nacional de Educação Permanente em Saúde, conforme relatado neste trabalho, há que se concordar que todos que apresentaram seus trabalhos buscavam reconhecimento e a valorização de suas experiências. E isso se confirma com o objetivo da Mostra de reconhecer e dar visibilidade a tais experiências. Como esta foi a primeira experiência na qual os trabalhadores do Ministério da Saúde tiveram a oportunidade de expor seus trabalhos voltados à educação permanente em saúde, espera-se que as próximas edições da Mostra evidenciem iniciativas mais consistentes e com potencial de multiplicação em outros ambientes da gestão federal do SUS.

Este estudo traz algumas pistas para qualificar o processo de organização de informações para publicação das experiências apresentadas, como: modificar a forma de orientar a elaboração das narrativas para que estas tragam elementos relevantes para replicação de iniciativas; e considerar a avaliação dos resultados alcançados na perspectiva dos diferentes sujeitos envolvidos nas experiências relatadas.

Uma forma de potencializar essas iniciativas seria a formação de profissionais para atuação como ativadores de processos de EP no Ministério da Saúde e o investimento nesses profissionais. Esses ativadores trabalhariam no sentido de fomentar práticas de EP, com todo o suporte necessário para que essas ações se fortaleçam e resultem na transformação de práticas profissionais e da própria organização do trabalho, conforme orienta a Política Nacional de Educação Permanente em Saúde (Pneps). Os ativadores teriam, ainda, o papel de fomentar a problematização das práticas e apoiar as equipes na pactuação dos processos de trabalho, conforme as diretrizes da Pneps.

Outro elemento importante seria um novo estudo que comparasse as produções das diferentes Mostras para acompanhar a evolução da implementação da EP no âmbito da gestão federal do SUS e que também aprofunde a discussão acerca das categorias definidas neste trabalho. 


\section{REFERÊNCIAS}

BRASIL. Constituição (1998). Constituição da República Federativa do Brasil. Brasília: Senado Federal, 1988.

. Ministério da Saúde. Lei o 8.080, de 19 de setembro de 1990. Dispõe sobre as condições para a promoção, proteção e recuperação da saúde, a organização e o funcionamento dos serviços correspondentes e dá outras providências. Diário Oficial da União, Poder Executivo, Brasília, DF, 20 set. 1990. Seção 1, p. 18055.

. Decreto 5.707, de 23 de fevereiro de 2006. Institui a Política e as Diretrizes para o Desenvolvimento de Pessoal da administração pública federal direta, autárquica e fundacional, e regulamenta dispositivos da Lei no 8.112 , de 11 de dezembro de 1990. Diário Oficial da União, Poder Executivo, Brasília, DF, 24 fev. 2006. Seção 1, p. 3 e 4.

. Portaria GM/MS no 198, de 13 de fevereiro de 2004. Institui a Política Nacional de Educação Permanente em Saúde como estratégia do Sistema Único de Saúde para a formação e o desenvolvimento de trabalhadores para o setor dá outras providências. Diário Oficial da União, Brasília, DF, 16 fev. 2004. Seção 1, p. 37-41.

. Portaria GM/MS no 1.996, de 20 de agosto de 2007. Dispõe sobre as diretrizes para a implementação da Política Nacional de Educação Permanente em Saúde e dá outras providências. Diário Oficial da União, Poder Executivo, Brasília, DF, n. 162, 22 ago. 2007. Seção 1, p. 34-38.

Portaria GM/MS no 278, de 27 de fevereiro de 2014. Institui diretrizes para implementação da Política de Educação Permanente em Saúde, no âmbito do Ministério da Saúde (MS). Diário Oficial da União, Poder Executivo, Brasília, DF, 28 fev. 2014. Seção 1, p. 59-60.

. Secretaria-Executiva. Subsecretaria de Assuntos Administrativos. Educação Permanente em Saúde: um movimento instituinte de novas práticas no Ministério da Saúde: Agenda 2014. Brasília, 2014.

. Portaria GM/MS no 2.761, de 19 de novembro de 2013. Institui a Política Nacional de Educação Popular em Saúde no âmbito do Sistema Único de Saúde (PNEPS-SUS). Diário Oficinal da União, Poder Executivo, Brasília, DF, 20 nov. 2013, Seção 1, p.62-63.

Secretaria de Gestão do Trabalho e da Educação na Saúde. Departamento de Gestão da Educação na Saúde. A educação permanente entra na roda: polos de educação permanente em saúde: conceitos e caminhos a percorrer. Brasília, 2005. 
. Secretaria de Gestão do Trabalho e da Educação na Saúde. Departamento de Gestão da Educação na Saúde. Política Nacional de Educação Permanente em Saúde. Brasília, 2009. (Série B. Textos Básicos de Saúde; Série Pactos pela Saúde, 2006, v. 9).

. Ministério da Saúde. Secretaria de Gestão do Trabalho e da Educação na Saúde. Departamento de Gestão da Educação na Saúde. Política de educação e desenvolvimento para o SUS: caminhos para a educação permanente em saúde: pólos de educação permanente em saúde - Brasília: Ministério da Saúde, 2004.

. Conselho Nacional de Secretários de Saúde. A Gestão do Trabalho e da Educação na Saúde. Brasília, 2011 (Coleção Para Entender a Gestão do SUS 2011, v. 9).

. Secretaria-Executiva. Subsecretaria de Assuntos Administrativos. Coletânea de narrativas: experiências da I Mostra Nacional de Educação Permanente em Saúde: reconhecendo as práticas dos trabalhadores do Ministério da Saúde. Brasília: Ministério da Saúde, 2015.

. Ministério da Saúde. O SUS de A a Z: garantindo saúde nos municípios/ Ministério da Saúde, Conselho Nacional de Secretários Municipais de Saúde. Brasília: Ministério da Saúde: 2005.

BARDIN, L. Análise de Conteúdo. Lisboa: Edições 70, 1977.

CAMPOS, Gastão Wagner de Sousa. Políticas de formação de pessoal para o SUS: reflexões fragmentadas. Cadernos $R H$ Saúde, Brasília, v. 3, n. 1, mar. 2006. Ministério da Saúde, Secretaria de Gestão do Trabalho e da Educação na Saúde.

CAMPOS, Gastão Wagner de Souza. Efeito Paidéia e o campo da saúde: reflexões sobre a relação entre o sujeito e o mundo da vida. Trabalho, Educação e Saúde, v. 4, n.1, p.19-31, 2006.

CARROTA, F.; KAWAMURA, D.; SALAZAR, J. Educação Permanente em Saúde: uma estratégia de gestão para pensar, refletir e construir práticas educativas e processos de trabalhos. Saúde e Sociedade, v. 18, supl.1, 2009.

CECCIM, Ricardo Burg. Educação Permanente em Saúde: desafio ambicioso e necessário. Interface - Comunicação, Saúde, Educação, Botucatu, v. 9, n. 16, p. 161-77, set. 2004/ fev. 2005.

CECCIM, Ricardo Burg; FERLA, Alcindo Antônio. Educação e Saúde: ensino e cidadania como travessia de fronteiras. Revista Trabalho, Educação e Saúde, v. 6 n. 3, p. 443-456, nov. 2008/fev.2009. 
Educação Permanente em Saúde. In: Dicionário da Educação Profissional em Saúde. PEREIRA, Isabel Brasil; LIMA, Júlio César França (Orgs.). 2. ed. rev. ampl. Rio de Janeiro: EPSJV, 2008. p. 162 a 168.

CECCIM, Ricardo Burg; FEUERWERKER, Laura C. M. O quadrilátero da formação para a área da saúde: ensino, gestão, atenção e controle social. Physis, Rio de Janeiro, v. 14, n. 1, p. 41-65, jun. 2004. Disponível em <http://www.scielo.br/scielo.php?script=sci_arttext\&pid=S0103$73312004000100004 \&$ lng $=$ pt\&nrm=iso $>$. Acesso em 17 nov. 2016. http://dx.doi.org/10.1590/S0103-73312004000100004.

CRESWELL, John W. Projeto de Pesquisa: métodos qualitativo, quantitativo e misto. 3. ed. Porto Alegre: Artmed, 2010.

DAVINI, Maria Cristina. Enfoques, problemas e perspectivas na educação permanente dos recursos humanos de saúde. In: Política Nacional de Educação Permanente em Saúde. Brasília: Ministério da Saúde, 2009, p. 39-63 (Série B. Textos Básicos de Saúde) (Série Pactos pela Saúde 2006; v. 9).

DELUIZ, N. A globalização econômica e os desafios à formação profissional. Boletim Técnico do Senac, Rio de Janeiro, v. 22, n. 2, maio/ago. 1996.

FAURE, E. Aprender a ser. Lisboa: Bertrand; Difusão Européia do Livro, 1974.

FRANCO, Tulio Batista. Produção do cuidado e produção pedagógica: integração de cenários do sistema de saúde no Brasil. Revista interface - Comunicação, Saúde, Educação, v. 11, n. 23, p.427-38, set./dez. 2007.

FREIRE, Paulo. Pedagogia da autonomia: saberes necessários à prática educativa. São Paulo: Paz e Terra, 1996.

. Pedagogia do Oprimido. 17 ed. Rio de Janeiro: Paz e Terra, 1987.

GADOTTI, Moacir. A questão da educação formal/não formal. Institut International Des Droits de L'Enfant (IDE). Droit à l'éducation: solution à tous les problèmes ou problème sans solution? Sion (Suisse), 18 au 22 octobre 2005.

JOAZEIRO, Edna Maria Goulart; SCHERER, Magda Duarte dos Anjos. Trabalho coletivo e transmissão de saberes na saúde: desafios da assistência e da formação. Revista Tempus Actas de Saúde Coletiva. 2012. p. 279-93.

JOHANN, Jorge Renato. Educação e ética: em busca de uma aproximação. Porto Alegre: Edipucrs, 2009. 130 p. 
KINGDON, John W. Agendas, alternatives, and Public Policies. 2. ed. New York: Longman, 2003. 253p.

MARANDOLA T. R. et al. Educação Permanente em Saúde: conhecer para compreender. Revista Espaço para a Saúde, Londrina, v. 10, n. 2, p. 53-60, jun. 2009.

MERHY, Emerson Elias; FEUERWERKER, Laura Camargo Macruz. Novo olhar sobre as tecnologias de saúde: uma necessidade contemporânea. In: MANDARINO, A. C. S.; GOMBERG, E. (Orgs.). Leituras de novas tecnologias e saúde. São Cristóvão: Editora UFS, 2009. p. 29-74.

MERHY, Emerson Elias. O desafio que a educação permanente tem em si: a pedagogia da implicação. Interface (Botucatu), Botucatu, v. 9, n. 16, p. 172174, fev. 2005. Disponível em:

$<$ http://www.scielo.br/scielo.php?script=sci_arttext\&pid=S1414-

$32832005000100015 \&$ Ing=pt\&nrm=iso >. Acesso em: 17 nov. 2016.

http://dx.doi.org/10.1590/S1414-32832005000100015.

MERHY, Emerson Elias; FEUERWERKER, Laura Camargo Macruz; CECCIM, Ricardo Burg. Educación Permanente en Salud: una Estrategia para Intervenir en la Micropolítica del Trabajo en Salud. Salud colectiva, Lanús, v. 2, n. 2, p. 147160, agosto 2006. Disponível em:

<http://www.scielo.org.ar/scielo.php?script=sci_arttext\&pid=S1851-

$82652006000200004 \& \operatorname{lng}=e s \& n r m=i s o>$. Acesso em: 16 nov. 2016.

FEUERWERKER, Laura Camargo Macruz. Educação Permanente em Saúde: educação, saúde, gestão e produção do cuidado In: (Org.). Micropolítica e saúde: produção do cuidado, gestão e formação. Porto Alegre: Rede UNIDA, 2014. 174 p. (Coleção Micropolítica do Trabalho e o Cuidado em Saúde).

MINAYO, Maria Cecília de Souza. O desafio do conhecimento: pesquisa qualitativa em saúde. 11. ed. São Paulo: Hucitec, 2008.

MINAYO, Maria Cecília de Souza. Pesquisa social: teoria, método e criatividade. Suely Ferreira Deslandes, Romeu Gomes; Maria Cecília de Souza Minayo (organizadora). 29. ed. Petrópolis, RJ: Vozes, 2010.

ORGANIZAÇÃO DAS NAÇÕES UNIDAS PARA A EDUCAÇÃO, A CIÊNCIA E A CULTURA - UNESCO. Learning: the treasure within. report to UNESCO of the International Commission on Education for the Twenty first Century (highlights). Paris: UNESCO, 1996.

QUINTANA, P.; ROSCHKE, M. A.; RIBEIRO, E. C. Educación permanente, processo de trabajo y calidad de servicio em salud. In: HADDAD, Q. J. et al. Educación permanente e personal de salud. Washington: OPS, 1994. 
SAVIANI, Dermeval. Pedagogia Histórico-Crítica - primeiras aproximações. 4. ed. Campinas, SP: Autores Associados, 1994.

TRINQUET, Pierre. Trabalho e Educação: o método ergológico. Revista HISTEDBR On-line, Campinas, número especial, p. 93-113, ago.2010. ISSN: 1676-2584.

WERTHEIN, Jorge. Fundamentos da nova educação. Brasília: UNESCO, 2000.

YVES, Schwartz. A experiência é formadora? Revista Educação \& Realidade.v. 35, n. 1, p. 35-48, jan./abr. 2010. 
ANEXO A - PARECER CONSUBSTANCIADO DO CEP

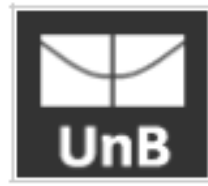

\section{FACULDADE DE CIÊNCIAS DA SAÚDE DA UNIVERSIDADE DE BRASÍLIA - CEP/FS-UNB}

\section{PARECER CONSUBSTANCIADO DO CEP}

\section{DADOS DO PROJETO DE PESQUISA}

Título da Pesquisa: Educação Permanente em Saúde como ferramenta de gestão no âmbito federal do Sistema Único de Saúde

Pesquisador: Priscila de Figueiredo Aquino Cardoso

Área Temática:

Versão: 3

CAAE: 45423914.4 .0000 .0030

Instituição Proponente: Departamento de Saúde Coletiva

Patrocinador Principal: Financiamento Próprio

DADOS DO PARECER

Número do Parecer: 1.317.085

Apresentaçäo do Projeto:

"Resumo:

Desde 2004, vem se discutindo a Política Nacional de Educação Permanente em Saúde - PNEPS. Mas, somente em 2014, apesar do movimento ter iniciado em 2012, internamente no Ministério da Saúde, foi publicada a Portaria $G M n^{\circ} 278$, instituindo diretrizes para a implementação da Política de Educação Permanente no âmbito do Ministério da Saúde. Essa Portaria reafirma os princípios e diretrizes da Educação Permanente como estratégia para a formação e o desenvolvimento dos trabalhadores do Ministério da Saúde (sede e unidades descentralizadas). Por ser um processo novo no âmbito interno do Ministério da Saúde, gera muitas indagações sobre o seu verdadeiro potencial transformador e de impacto positivo nos processos de trabalho. Nesse sentido, este trabalho se propõe a analisar o processo de implementação da Educação Permanente em Saúde na gestão federal do Sistema Único de Saúde a partir do desenvolvimento de estratégias de EP no âmbito do Ministério da Saúde."

"Metodologia Proposta:

Para desenvolver o tema "Educação Permanente em Saúde como ferramenta de gestão no âmbito federal do Sistema Único de Saúde", optou-se por desenvolver uma pesquisa qualitativa. A

Endereço: Faculdade de Clenclas da Saude - Campus Darcy Ribeiro

Balrro: Asa Norte CEP: $70.910-900$

UF: DF

Municiplo: BRASILIA

Telefone: $\quad(61) 3107-1947$

E-mall: ceofsunbœamall.com 


FACULDADE DE CIÊNCIAS DA
SAÚDE DA UNIVERSIDADE DE Slotoforma
BnB

Contnuaçlo do Parecer: 1317.085

pesquisa se restringirá à análise documental. Sendo assim, não haverá envolvimento com seres humanos. 0 método de pesquisa a ser adotado é o indutivo baseado na análise das experiências apresentadas na $1^{\mathrm{a}}$ Mostra Nacional de Educação Permanente."

"Critério de Exclusão:

Das 81 narrativas apresentadas na publicação "Coletânea de Narrativas: Experièncias da I Mostra Nacional de Educação Permanente em Saúde - reconhecendo as práticas dos trabalhadores do Ministério da Saúde". foram excluídas aquelas que não trazem elementos suficientes para caracterizaçäo."

\section{Objetivo da Pesquisa:}

"Objetivo primário:

Analisar o processo de implementação da Educação Permanente na gestão federal do Sistema Único de Saúde.

Objetivo Secundário:

a.Identificar experiências de Educação Permanente na gestão federal do SUS; b.Relacionar as experiências apresentadas no âmbito da gestão federal do SUS às diretrizes de Educação Permanente."

\section{Avaliaçäo dos Riscos e Beneficios:}

Segundo a pesquisadora:

"Riscos:

Não haverá riscos, pois não se trata de pesquisa que envolva seres humanos.

Beneficios:

Estudar a Educação Permanente enquanto ferramenta de gestäo no Ministério da Saúde é um tema de grande relevância para a instituição, vez que esta é a diretriz com que a Coordenação-Geral de Gestão de Pessoas, por meio da Coordenação de Desenvolvimento de Pessoas, vem trabalhando nos últimos dois anos como estratégia de valorização do trabalhador e do trabalho no Ministério da Saúde, de forma a fortalecer a gestão compartilhada e participativa além de favorecer a corresponsabilização dos sujeitos envolvidos nos processos de trabalho em saúde." 


FACULDADE DE CIÊNCIAS DA
SAÚDE DA UNIVERSIDADE DE
BnB

Contnuaçlo do Parecer. 1.317.085

Comentários e Considerações sobre a Pesquisa:

Trata-se de projeto de mestrado profissionalizante do Programa de Pós-Graduaçäo em Saúde Coletiva de Priscila de Figueiredo Aquino Cardoso, sob a orientação da Profa. Magda Duarte dos Anjos Scherer.

A metodologia proposta foi alterada para que seja realizada pesquisa qualitativa, restrita à análise documental. serão analisadas as experiências apresentadas na $1^{\text {a }}$ Mostra Nacional de Educação Permanente. Desta forma, a pesquisadora solicita dispensa de TCLE com a justificativa de que "A pesquisa se restringirá à análise documento, portanto não envolverá seres humanos. Sendo assim, não é necessário - TCLE.".

O Cronograma de Execução da Plataforma Brasil informa realização da pesquisa no período entre $10 / 12 / 2014$ e 31/12/2015, tendo sido retiradas as etapas de "Realizaçäo das entrevistas", "Continuidade da coleta de dados" e "Continuidade de realizaçäo das entrevistas".

Apresenta Orçamento Financeiro no valor total de RS 2.971,02, que serão custeados pela própria pesquisadora.

Consideraçōes sobre os Termos de apresentação obrigatória:

Documentos analisados para emissão do presente parecer.

- Informaçöes Básicas do Projeto - "PB_INFORMAÇŐES_BÁSICAS_DO_PROJETO_442773.pdf", postado em 30/10/2015;

- Carta de resposta às pendências - "CartaRespPendencias_CEPFS_29_10_2015.doc", postado em $30 / 10 / 2015$

Recomendações:

Não se aplica.

Conclusões ou Pendências e Lista de Inadequações:

O protocolo de pesquisa foi modificado para envolver somente análise documental, sendo utilizado somente base de dados pública. Assim sendo, as pendências anteriormente levantadas por este CEP não mais se aplicam.

Protocolo de pesquisa aprovado.

Consideraçōes Finais a critério do CEP:

Em acordo com a Resolução 466/12 CNS, ítens X.1.- 3.b. e XI.2.d, os pesquisadores responsáveis

Endereço: Faculdade de Clenclas da Saude - Campus Darcy Ribeiro

Bairro: Asa Norte $\quad$ CEP: $70.910-900$

UF: DF Municiplo: BRASILIA 
FACULDADE DE CIÊNCIAS DA

\section{SAÚDE DA UNIVERSIDADE DE SPlotoforma BRASÍLIA - CEP/FS-UNB}

Contnuaçlo do Parecer: 1.317.085

deverão apresentar relatórios parcial semestral e final do projeto de pesquisa, contados a partir da data de aprovação do protocolo de pesquisa.

Este parecer foi elaborado baseado nos documentos abaixo relacionados:

\begin{tabular}{|c|c|c|c|c|}
\hline Tipo Documento & Arquivo & Postagem & Autor & Situação \\
\hline $\begin{array}{l}\text { Informaçöes Básicas } \\
\text { do Projeto }\end{array}$ & $\begin{array}{l}\text { PB_INFORMAÇŌES_BÁSICAS_DO_P } \\
\text { ROJETO 442773.pdf }\end{array}$ & $\begin{array}{c}30 / 10 / 2015 \\
17: 32: 19\end{array}$ & & Aceito \\
\hline Outros & $\begin{array}{l}\text { CartaRespPendencias_CEPFS_29_10_ } \\
\text { 2015.doc }\end{array}$ & $\begin{array}{c}30 / 10 / 2015 \\
15: 44: 42\end{array}$ & $\begin{array}{l}\text { Priscila de Figueiredo } \\
\text { Aquino Cardoso }\end{array}$ & Aceito \\
\hline Outros & $\begin{array}{l}\text { NOVAS CORREÇÖES REALIZADAS } \\
\text { CONFORME ORIENTAÇŐES DO } \\
\text { COMITÉ DE ÉTICA EM PESQUISA - } 28 \\
-07-2015 \text {.docx }\end{array}$ & $\begin{array}{c}28 / 07 / 2015 \\
17: 52: 18\end{array}$ & & Aceito \\
\hline Folha de Rosto & $\begin{array}{l}\text { Folha de rosto para pesquisa } \\
\text { envolvendo humanos - com CNPJ.pdf }\end{array}$ & $\begin{array}{c}28 / 07 / 2015 \\
17: 39: 33 \\
\end{array}$ & & Aceito \\
\hline Outros & $\begin{array}{l}\text { CORREÇÖES REALIZADAS } \\
\text { CONFORME ORIENTAÇŐES DO } \\
\text { COMITE DE ÉTICA EM }\end{array}$ & $\begin{array}{c}19 / 05 / 2015 \\
12: 06: 41\end{array}$ & & Aceito \\
\hline Outros & $\begin{array}{l}\text { CURRICULO - Magda Duarte dos Anjos } \\
\text { Scherer.docx }\end{array}$ & $\begin{array}{c}25 / 03 / 2015 \\
09: 57: 30\end{array}$ & & Aceito \\
\hline $\begin{array}{l}\text { Projeto Detalhado / } \\
\text { Brochura } \\
\text { Investigador }\end{array}$ & $\begin{array}{l}\text { Projeto - Mestrado em Saúde Coletiva - } \\
\text { Priscila Aquino - } 2014 \text { - revisado em 16- } \\
\text { 11-2014.doc }\end{array}$ & $\begin{array}{c}11 / 12 / 2014 \\
15: 35: 46\end{array}$ & & Aceito \\
\hline Outros & Priscila 3.pdf & $\begin{array}{c}11 / 12 / 2014 \\
15: 32: 09\end{array}$ & & Aceito \\
\hline Outros & Priscila 2.pdf & $\begin{array}{c}11 / 12 / 2014 \\
15: 29: 34\end{array}$ & & Aceito \\
\hline Outros & Priscila 1.pdf & $\begin{array}{c}11 / 12 / 2014 \\
15: 28: 45 \\
\end{array}$ & & Aceito \\
\hline Outros & Priscila.pdf & $\begin{array}{c}11 / 12 / 2014 \\
15: 27: 30\end{array}$ & & Aceito \\
\hline
\end{tabular}

Situaçäo do Parecer:

Aprovado

Necessita Apreciação da CONEP:

Não

Endereço: Faculdade de Clenclas da Saude - Campus Darcy Ribelro

Bairro: Asa Norte CEP: $70.910-900$

UF: DF Municiplo: BRASILIA

Telefone: (61)3107-1947 


\section{APÊNDICE A - QUADRO ANALÍTICO DAS NARRATIVAS}

\begin{tabular}{|c|c|c|c|c|c|c|c|c|c|}
\hline Narrativas & Local & Início & $\begin{array}{l}\text { Concepção de } \\
\text { educação } \\
\text { destacada no } \\
\text { texto }\end{array}$ & $\begin{array}{l}\text { Inferências a partir } \\
\text { de trechos das } \\
\text { narrativas que } \\
\text { correspondem a } \\
\text { concepções de } \\
\text { educação }\end{array}$ & Participantes & Ações & Método & $\begin{array}{l}\text { Objetivo(s) das } \\
\text { ações }\end{array}$ & $\begin{array}{l}\text { Mudanças } \\
\text { ocorridas }\end{array}$ \\
\hline $\begin{array}{l}\text { "A arte na } \\
\text { Enfermagem como } \\
\text { estratégia de } \\
\text { transformação das } \\
\text { relações de } \\
\text { trabalho: oficina } \\
\text { do cuidador" }\end{array}$ & $\begin{array}{l}\text { Hospital } \\
\text { Federal do } \\
\text { Andaraí - Rio } \\
\text { de Janeiro }\end{array}$ & 2013 & $\begin{array}{l}\text { NÃO DECLARADA } \\
\text { EXPRESSAMENTE }\end{array}$ & $\begin{array}{l}\text { Destaca aspectos } \\
\text { como valorização e } \\
\text { humanização dos } \\
\text { profissionais de } \\
\text { enfermagem. }\end{array}$ & $\begin{array}{l}\text { Profissionais de } \\
\text { enfermagem do } \\
\text { Hospital Federal do } \\
\text { Andaraí }\end{array}$ & $\begin{array}{l}\text { Desenvolvimento } \\
\text { de atividades } \\
\text { lúdicas envolvendo } \\
\text { os profissionais de } \\
\text { enfermagem do } \\
\text { Hospital. }\end{array}$ & $\begin{array}{l}\text { A arte foi utilizada } \\
\text { como instrumento } \\
\text { de transformação. }\end{array}$ & $\begin{array}{l}\text { Sensibilizar os } \\
\text { trabalhadores de } \\
\text { Enfermagem para } \\
\text { o } \\
\text { autoconhecimento } \\
\text { e estimular o } \\
\text { autocuidado. }\end{array}$ & $\begin{array}{l}\text { Pequenas } \\
\text { mudanças que, } \\
\text { indiretamente, } \\
\text { repercutem no dia } \\
\text { a dia do } \\
\text { profissional como } \\
\text { perda de peso, } \\
\text { controle da } \\
\text { hipertensão, } \\
\text { inclusão de } \\
\text { atividade física no } \\
\text { cotidiano, etc. }\end{array}$ \\
\hline $\begin{array}{l}\text { "A Educação } \\
\text { Permanente em } \\
\text { Saúde como } \\
\text { ferramenta de } \\
\text { trabalho na clínica } \\
\text { de neurocirurgia" }\end{array}$ & $\begin{array}{l}\text { Hospital } \\
\text { Federal de } \\
\text { Bonsucesso - } \\
\text { Rio de Janeiro }\end{array}$ & $\begin{array}{c}\text { Não foi } \\
\text { mencionado. }\end{array}$ & $\begin{array}{l}\text { "No processo } \\
\text { educativo da } \\
\text { Educação } \\
\text { Permanente em } \\
\text { Saúde, o cotidiano } \\
\text { do trabalho } \\
\text { encontra-se em } \\
\text { constante análise, } \\
\text { buscando-se } \\
\text { avaliação e } \\
\text { reflexão em } \\
\text { espaços coletivos } \\
\text { dos atos } \\
\text { produzidos. Nesse } \\
\text { processo está } \\
\text { inserida a } \\
\text { educação em }\end{array}$ & $\begin{array}{l}\text { Processo educativo } \\
\text { no qual o cotidiano } \\
\text { do trabalho é } \\
\text { constantemente } \\
\text { analisado, } \\
\text { buscando-se } \\
\text { avaliação e } \\
\text { reflexão em } \\
\text { espaços coletivos. } \\
\text { Abrange a } \\
\text { educação em } \\
\text { serviço com } \\
\text { conteúdos, } \\
\text { instrumentos e } \\
\text { recursos voltados } \\
\text { para a qualificação } \\
\text { técnica submetida }\end{array}$ & \begin{tabular}{|l|} 
Equipe de \\
enfermagem do \\
Hospital Federal de \\
Bonsucesso.
\end{tabular} & $\begin{array}{l}\text { Rodas de conversa } \\
\text { mensais abordando } \\
\text { temas específicos } \\
\text { com a equipe de } \\
\text { enfermagem do } \\
\text { Hospital. }\end{array}$ & \begin{tabular}{|l} 
Os temas das \\
Rodas de \\
Conversa são \\
escolhidos com \\
base nos \\
diagnósticos dos \\
pacientes \\
internados e na \\
relevância, além \\
do levantamento \\
de necessidades e \\
de conduta. Os \\
residentes de \\
enfermagem são \\
os responsáveis \\
pelo \\
direcionamento
\end{tabular} & $\begin{array}{l}\text { * Criar espaços } \\
\text { coletivos para } \\
\text { discussão, } \\
\text { avaliação e } \\
\text { reflexão dos atos } \\
\text { produzidos no } \\
\text { cotidiano; } \\
\text { * Estimular e } \\
\text { facilitar o processo } \\
\text { de ensino- } \\
\text { aprendizagem; } \\
\text { * Relacionar o } \\
\text { aprendizado com a } \\
\text { prática assistencial } \\
\text { e buscar melhorias } \\
\text { na qualidade do } \\
\text { serviço prestado }\end{array}$ & $\begin{array}{l}\text { *Melhora na } \\
\text { qualidade da } \\
\text { assistência } \\
\text { prestada ao } \\
\text { usuário a partir } \\
\text { das discussões } \\
\text { sobre a patologia, } \\
\text { suas } \\
\text { especificidades e } \\
\text { o planejamento } \\
\text { de ações } \\
\text { direcionadas; } \\
\text { *Segurança e } \\
\text { entusiasmo da } \\
\text { equipe ao prestar } \\
\text { assistência e } \\
\text { sentir-se parte do }\end{array}$ \\
\hline
\end{tabular}




\begin{tabular}{|c|c|c|c|c|c|c|c|c|c|}
\hline \multirow[t]{2}{*}{ Narrativas } & Local & Início & $\begin{array}{l}\text { Concepção de } \\
\text { educação } \\
\text { destacada no } \\
\text { texto }\end{array}$ & $\begin{array}{l}\text { Inferências a partir } \\
\text { de trechos das } \\
\text { narrativas que } \\
\text { correspondem a } \\
\text { concepções de } \\
\text { educação }\end{array}$ & Participantes & Ações & Método & $\begin{array}{l}\text { Objetivo(s) das } \\
\text { ações }\end{array}$ & $\begin{array}{c}\text { Mudanças } \\
\text { ocorridas }\end{array}$ \\
\hline & & & $\begin{array}{l}\text { serviço que coloca } \\
\text { a pertinência dos } \\
\text { conteúdos, } \\
\text { instrumentos e } \\
\text { recursos para a } \\
\text { qualificação } \\
\text { técnica submetida } \\
\text { a um projeto de } \\
\text { mudanças } \\
\text { institucionais ou } \\
\text { de mudança da } \\
\text { orientação das } \\
\text { ações prestadas." }\end{array}$ & $\begin{array}{l}\text { a um projeto de } \\
\text { mudanças } \\
\text { institucionais ou } \\
\text { de orientação das } \\
\text { ações prestadas. }\end{array}$ & & & dos assuntos. & $\begin{array}{l}\text { ao usuário, } \\
\text { levando-se em } \\
\text { consideração, } \\
\text { nesse processo, as } \\
\text { vivências, os } \\
\text { pensamentos e os } \\
\text { saberes de cada } \\
\text { integrante da } \\
\text { equipe. }\end{array}$ & $\begin{array}{l}\text { processo; } \\
\text { *Satisfação do } \\
\text { usuário em ter } \\
\text { suas necessidades } \\
\text { atendidas e } \\
\text { diminuição de } \\
\text { riscos preveníveis. }\end{array}$ \\
\hline $\begin{array}{l}\text { "A importância do } \\
\text { patrimônio para o } \\
\text { controle geral dos } \\
\text { bens do acervo do } \\
\text { Ministério da } \\
\text { Saúde" }\end{array}$ & $\begin{array}{l}\text { Secretaria- } \\
\text { Executiva do } \\
\text { Ministério da } \\
\text { Saúde }\end{array}$ & $\begin{array}{c}\text { Não foi } \\
\text { mencionado. }\end{array}$ & $\begin{array}{l}\text { NÃO DECLARADA } \\
\text { EXPRESSAMENTE }\end{array}$ & \begin{tabular}{|l} 
Destaca uma \\
reflexão sobre a \\
importância do \\
envolvimento de \\
toda a equipe para \\
que percebam o \\
quanto \\
contribuem para o \\
resultado final de \\
seu setor.
\end{tabular} & \begin{tabular}{|l|} 
Uma equipe \\
específica na \\
Secretaria- \\
Executiva do \\
Ministério da \\
Saúde responsável \\
pela distribuição e \\
recolhimento dos \\
bens patrimoniais \\
permanentes da \\
instituição. \\
\end{tabular} & $\begin{array}{l}\text { As ações relatadas } \\
\text { referem-se às } \\
\text { atividades de } \\
\text { competência do } \\
\text { setor de } \\
\text { patrimônio do } \\
\text { Ministério da } \\
\text { Saúde. }\end{array}$ & $\begin{array}{l}\text { Não se percebe o } \\
\text { método na } \\
\text { narrativa. }\end{array}$ & $\begin{array}{l}\text { Não se percebe os } \\
\text { objetivos das } \\
\text { ações na narrativa. }\end{array}$ & $\begin{array}{l}\text { Não foi possível } \\
\text { identificar as } \\
\text { mudanças } \\
\text { ocorridas a partir } \\
\text { da experiência } \\
\text { apresentada na } \\
\text { narrativa. }\end{array}$ \\
\hline $\begin{array}{l}\text { "A importância da } \\
\text { educação para o } \\
\text { desenvolvimento } \\
\text { pessoal e } \\
\text { organizacional no } \\
\text { serviço público" }\end{array}$ & $\begin{array}{l}\text { Instituto } \\
\text { Nacional de } \\
\text { Traumatologia } \\
\text { e Ortopedia - } \\
\text { Rio de Janeiro }\end{array}$ & $\begin{array}{l}\text { Não foi } \\
\text { mencionado. } \\
\text { Apenas é } \\
\text { informado que } \\
\text { a pesquisa } \\
\text { realizada }\end{array}$ & $\begin{array}{l}\text { [...] educação para } \\
\text { o desenvolvimento } \\
\text { pessoal e } \\
\text { organizacional [...] }\end{array}$ & $\begin{array}{l}\text { Educação como } \\
\text { desenvolvimento } \\
\text { pessoal e } \\
\text { organizacional }\end{array}$ & $\begin{array}{l}\text { Agentes } \\
\text { Administrativos } \\
\text { que participaram } \\
\text { de cursos } \\
\text { ofertados pela } \\
\text { INTO no ano de }\end{array}$ & \begin{tabular}{|l|} 
Oferta de cursos \\
aos agentes \\
administrativos do \\
INTO no ano de \\
2010, seguida de \\
pesquisa para
\end{tabular} & \begin{tabular}{|l|} 
Realização de \\
pesquisa de \\
campo com \\
utilização de \\
questionário como \\
instrumento para
\end{tabular} & \begin{tabular}{|l} 
Verificar a \\
importância da \\
educação para o \\
desenvolvimento \\
pessoal e \\
organizacional do
\end{tabular} & $\begin{array}{l}\text { Segundo a } \\
\text { narrativa, houve } \\
\text { avanços em } \\
\text { programas de } \\
\text { educação no } \\
\text { Instituto, }\end{array}$ \\
\hline
\end{tabular}




\begin{tabular}{|c|c|c|c|c|c|c|c|c|c|}
\hline Narrativas & Local & Início & $\begin{array}{l}\text { Concepção de } \\
\text { educação } \\
\text { destacada no } \\
\text { texto }\end{array}$ & $\begin{array}{l}\text { Inferências a partir } \\
\text { de trechos das } \\
\text { narrativas que } \\
\text { correspondem a } \\
\text { concepções de } \\
\text { educação }\end{array}$ & Participantes & Ações & Método & $\begin{array}{l}\text { Objetivo(s) das } \\
\text { ações }\end{array}$ & $\begin{array}{l}\text { Mudanças } \\
\text { ocorridas }\end{array}$ \\
\hline & & $\begin{array}{l}\text { considerou os } \\
\text { cursos } \\
\text { realizados } \\
\text { pelos agentes } \\
\text { administrativos } \\
\text { do INTO no } \\
\text { ano de } 2010 .\end{array}$ & & & 2010. & \begin{tabular}{|l|} 
obter informações \\
sobre as \\
percepções dos \\
participantes a \\
respeito dos cursos \\
realizados.
\end{tabular} & \begin{tabular}{|l|} 
captação de \\
informações. \\
Também foi \\
realizada pesquisa \\
bibliográfica para \\
elaboração do \\
questionário e \\
interpretação dos \\
dados.
\end{tabular} & $\begin{array}{l}\text { INTO, a partir da } \\
\text { percepção dos } \\
\text { agentes } \\
\text { administrativos } \\
\text { sobre os cursos } \\
\text { nos quais } \\
\text { participaram no } \\
\text { ano de } 2010 .\end{array}$ & $\begin{array}{l}\text { aumento de } \\
\text { produtividade, } \\
\text { elevação dos } \\
\text { padrões de } \\
\text { qualidade, } \\
\text { diminuição de } \\
\text { erros e redução } \\
\text { de retrabalho. No } \\
\text { entanto, não fica } \\
\text { claro como esses } \\
\text { dados foram } \\
\text { aferidos. }\end{array}$ \\
\hline $\begin{array}{l}\text { "A } \\
\text { intersetorialidade } \\
\text { e a participação } \\
\text { social como } \\
\text { instrumentos } \\
\text { potentes no } \\
\text { planejamento de } \\
\text { ações de educação } \\
\text { permanente na } \\
\text { saúde indígena" }\end{array}$ & $\begin{array}{l}\text { Secretaria } \\
\text { Especial de } \\
\text { Saúde Indígena } \\
\text { do Ministério } \\
\text { da Saúde }\end{array}$ & $\begin{array}{l}\text { Setembro de } \\
2014\end{array}$ & $\begin{array}{l}\text { NÃO DECLARADA } \\
\text { EXPRESSAMENTE }\end{array}$ & $\begin{array}{l}\text { Uso de } \\
\text { metodologias } \\
\text { ativas, } \\
\text { considerando a } \\
\text { importância da } \\
\text { construção } \\
\text { conjunta de } \\
\text { saberes e práticas } \\
\text { a partir da } \\
\text { realidade e do } \\
\text { conhecimento } \\
\text { prévio dos } \\
\text { conselheiros que } \\
\text { participariam da } \\
\text { capacitação. } \\
\text { Proposta de } \\
\text { diálogo horizontal. }\end{array}$ & $\begin{array}{l}\text { Profissionais das } \\
\text { áreas de Educação } \\
\text { Permanente em } \\
\text { Saúde e do } \\
\text { controle social do } \\
\text { DSEl, membros do } \\
\text { Departamento de } \\
\text { Antropologia da } \\
\text { Universidade } \\
\text { Federal de Santa } \\
\text { Catarina (UFSC), } \\
\text { apoiadores da } \\
\text { Política Nacional } \\
\text { de Humanização } \\
\text { do Ministério da } \\
\text { Saúde, lideranças } \\
\text { indígenas... }\end{array}$ & $\begin{array}{l}\text { Organização de } \\
\text { encontros com um } \\
\text { grupo intersetorial } \\
\text { para estruturar a } \\
\text { capacitação dos } \\
\text { conselheiros. }\end{array}$ & \begin{tabular}{|l|} 
Inicialmente, \\
formou-se um \\
grupo intersetorial \\
de trabalho para \\
pensar na \\
capacitação dos \\
conselheiros. Em \\
seguida, foram \\
realizados \\
encontros com \\
esse grupo nos \\
quais os temas e a \\
metodologia a ser \\
adotada na \\
capacitação foram \\
discutidos. Para \\
discussão da \\
metodologia e dos
\end{tabular} & \begin{tabular}{|l} 
Organizar e \\
executar a \\
capacitação dos \\
conselheiros \\
distritais de saúde \\
indígena do \\
Distrito Sanitário \\
Especial Indígena \\
(DSEl) do Interior \\
Sul.
\end{tabular} & $\begin{array}{l}\text { Segundo a } \\
\text { narrativa, a partir } \\
\text { das discussões no } \\
\text { grupo, os } \\
\text { organizadores do } \\
\text { curso } \\
\text { identificaram os } \\
\text { desafios presentes } \\
\text { na tentativa de } \\
\text { implantar um } \\
\text { sistema de } \\
\text { controle social } \\
\text { ocidental em } \\
\text { culturas que } \\
\text { possuem modelos } \\
\text { diferenciados de } \\
\text { organização e } \\
\text { hierarquia. }\end{array}$ \\
\hline
\end{tabular}




\begin{tabular}{|c|c|c|c|c|c|c|c|c|c|}
\hline Narrativas & Local & Início & $\begin{array}{l}\text { Concepção de } \\
\text { educação } \\
\text { destacada no } \\
\text { texto }\end{array}$ & $\begin{array}{l}\text { Inferências a partir } \\
\text { de trechos das } \\
\text { narrativas que } \\
\text { correspondem a } \\
\text { concepções de } \\
\text { educação }\end{array}$ & Participantes & Ações & Método & $\begin{array}{l}\text { Objetivo(s) das } \\
\text { ações }\end{array}$ & $\begin{array}{l}\text { Mudanças } \\
\text { ocorridas }\end{array}$ \\
\hline & & & & & & & $\begin{array}{l}\text { temas, também } \\
\text { foram convidados } \\
\text { membro da } \\
\text { Fundação } \\
\text { Nacional do Índio } \\
\text { (FUNAI), da } \\
\text { Controladoria- } \\
\text { Geral da União } \\
\text { (CGU) e da } \\
\text { Universidade } \\
\text { Federal de Santa } \\
\text { Catarina (UFSC). }\end{array}$ & & $\begin{array}{l}\text { Também foi } \\
\text { destaque a } \\
\text { aproximação } \\
\text { entre as } \\
\text { realidades } \\
\text { indígenas e as } \\
\text { diretrizes para o } \\
\text { controle social } \\
\text { previstas no SUS. }\end{array}$ \\
\hline $\begin{array}{l}\text { "A linguagem } \\
\text { teatral como meio } \\
\text { de integração, } \\
\text { motivação e } \\
\text { promoção de } \\
\text { ações de Educação } \\
\text { Permanente em } \\
\text { Saúde no } \\
\text { NEMS/ES" }\end{array}$ & $\begin{array}{l}\text { Núcleo } \\
\text { Estadual do } \\
\text { Ministério da } \\
\text { Saúde no } \\
\text { Espírito Santo }\end{array}$ & $\begin{array}{l}2004 \text { (término } \\
\text { em 2012) }\end{array}$ & $\begin{array}{l}\text { NÃO DECLARADA } \\
\text { EXPRESSAMENTE }\end{array}$ & \begin{tabular}{|l|} 
Destaca alguns \\
termos \\
correlacionados à \\
Educação \\
Permanente em \\
Saúde como: \\
mudanças nas \\
relações de \\
trabalho; \\
valorização de \\
conhecimentos \\
dos servidores a \\
partir de suas \\
realidades; gestão \\
participativa; \\
trabalhadores \\
assumindo o \\
protagonismo;
\end{tabular} & $\begin{array}{l}\text { Trabalhadores do } \\
\text { Núcleo Estadual do } \\
\text { Ministério da } \\
\text { Saúde no Espírito } \\
\text { Santo. }\end{array}$ & $\begin{array}{l}\text { Não ficou claro } \\
\text { quais ações foram } \\
\text { desenvolvidas no } \\
\text { Núcleo. }\end{array}$ & $\begin{array}{l}\text { Segundo a } \\
\text { narrativa, o teatro } \\
\text { foi usado como } \\
\text { linguagem no } \\
\text { processo de } \\
\text { educação dos } \\
\text { trabalhadores do } \\
\text { Núcleo, mas não } \\
\text { ficou claro como } \\
\text { isso se deu. }\end{array}$ & $\begin{array}{l}\text { Na narrativa não } \\
\text { ficam claros os } \\
\text { objetivos das } \\
\text { ações realizadas } \\
\text { no Núcleo. }\end{array}$ & $\begin{array}{l}\text { Não foi possível } \\
\text { identificar as } \\
\text { mudanças } \\
\text { ocorridas a partir } \\
\text { da experiência } \\
\text { apresentada na } \\
\text { narrativa. No } \\
\text { entanto, é } \\
\text { explicitado o } \\
\text { desejo de retomar } \\
\text { o projeto } \\
\text { encerrado em } \\
2012 \text { e fortalecê- } \\
\text { lo com outras } \\
\text { atividades } \\
\text { culturais como } \\
\text { cinema, dança e } \\
\text { poesia. }\end{array}$ \\
\hline
\end{tabular}




\begin{tabular}{|c|c|c|c|c|c|c|c|c|c|}
\hline \multirow[t]{2}{*}{ Narrativas } & \multirow[t]{2}{*}{ Local } & \multirow[t]{2}{*}{ Início } & \multirow[t]{2}{*}{$\begin{array}{l}\text { Concepção de } \\
\text { educação } \\
\text { destacada no } \\
\text { texto }\end{array}$} & $\begin{array}{l}\text { Inferências a partir } \\
\text { de trechos das } \\
\text { narrativas que } \\
\text { correspondem a } \\
\text { concepções de } \\
\text { educação }\end{array}$ & Participantes & Ações & Método & \multirow[t]{2}{*}{$\begin{array}{l}\text { Objetivo(s) das } \\
\text { ações }\end{array}$} & \multirow[t]{2}{*}{$\begin{array}{l}\text { Mudanças } \\
\text { ocorridas }\end{array}$} \\
\hline & & & & $\begin{array}{l}\text { gestão } \\
\text { compartilhada. }\end{array}$ & & & & & \\
\hline $\begin{array}{l}\text { "A tecitura da I } \\
\text { Mostra Nacional } \\
\text { de Educação } \\
\text { Permanente - } \\
\text { reconhecendo as } \\
\text { práticas dos } \\
\text { trabalhadores do } \\
\text { Ministério da } \\
\text { Saúde" }\end{array}$ & $\begin{array}{l}\text { Secretaria de } \\
\text { Gestão } \\
\text { Estratégica e } \\
\text { Participativa do } \\
\text { Ministério da } \\
\text { Saúde }\end{array}$ & $\begin{array}{c}\text { Não foi } \\
\text { mencionado. }\end{array}$ & $\begin{array}{l}{[\ldots] \text { práticas }} \\
\text { educacionais que } \\
\text { promovam a } \\
\text { aprendizagem } \\
\text { significativa dos } \\
\text { sujeitos. }\end{array}$ & \begin{tabular}{|l} 
Fomentar, nos \\
espaços coletivos \\
de trabalho, \\
práticas \\
educacionais que \\
promovam a \\
aprendizagem \\
significativa dos \\
sujeitos. \\
Ampliar a \\
capacidade \\
reflexiva dos \\
trabalhadores, a \\
partir de suas \\
vivências \\
individuais e \\
coletivas.
\end{tabular} & $\begin{array}{l}\text { Trabalhadores do } \\
\text { Departamento } \\
\text { Nacional de } \\
\text { Auditoria do SUS. }\end{array}$ & $\begin{array}{l}\text { Não ficou claro } \\
\text { quais ações foram } \\
\text { desenvolvidas na } \\
\text { área. }\end{array}$ & $\begin{array}{l}\text { Não se percebe o } \\
\text { método na } \\
\text { narrativa. }\end{array}$ & $\begin{array}{l}\text { Não se percebe os } \\
\text { objetivos das } \\
\text { ações na narrativa. }\end{array}$ & $\begin{array}{l}\text { Não foi possível } \\
\text { identificar as } \\
\text { mudanças } \\
\text { ocorridas a partir } \\
\text { da experiência } \\
\text { apresentada na } \\
\text { narrativa. }\end{array}$ \\
\hline
\end{tabular}




\begin{tabular}{|c|c|c|c|c|c|c|c|c|c|}
\hline Narrativas & Local & Início & $\begin{array}{l}\text { Concepção de } \\
\text { educação } \\
\text { destacada no } \\
\text { texto }\end{array}$ & $\begin{array}{l}\text { Inferências a partir } \\
\text { de trechos das } \\
\text { narrativas que } \\
\text { correspondem a } \\
\text { concepções de } \\
\text { educação }\end{array}$ & Participantes & Ações & Método & $\begin{array}{l}\text { Objetivo(s) das } \\
\text { ações }\end{array}$ & $\begin{array}{l}\text { Mudanças } \\
\text { ocorridas }\end{array}$ \\
\hline $\begin{array}{l}\text { "Aperfeiçoamento } \\
\text { sobre as } \\
\text { atribuições e } \\
\text { competências dos } \\
\text { AIS, Aisans e } \\
\text { profissionais do } \\
\text { DSEl Yanomami" }\end{array}$ & $\begin{array}{l}\text { Secretaria } \\
\text { Especial de } \\
\text { Saúde Indígena } \\
\text { do Ministério } \\
\text { da Saúde }\end{array}$ & $\begin{array}{c}\text { Não foi } \\
\text { mencionado. }\end{array}$ & $\begin{array}{l}\text { "A Educação } \\
\text { Permanente em } \\
\text { Saúde parte do } \\
\text { princípio de que a } \\
\text { condição } \\
\text { indispensável para } \\
\text { uma pessoa ou } \\
\text { uma organização } \\
\text { decidir mudar ou } \\
\text { incorporar novos } \\
\text { elementos à sua } \\
\text { prática e a seus } \\
\text { conceitos é a } \\
\text { detecção e } \\
\text { contato com os } \\
\text { desconfortos } \\
\text { experimentados } \\
\text { no cotidiano do } \\
\text { trabalho, a } \\
\text { percepção de que } \\
\text { a maneira vigente } \\
\text { de fazer ou de } \\
\text { pensar é } \\
\text { insuficiente ou } \\
\text { insatisfatória para } \\
\text { dar conta dos } \\
\text { desafios do } \\
\text { trabalho." }\end{array}$ & \begin{tabular}{|l} 
Parte do princípio \\
de que a condição \\
indispensável para \\
uma pessoa ou \\
uma organização \\
decidir mudar ou \\
incorporar novos \\
elementos à sua \\
prática e aos seus \\
conceitos é a \\
detecção e o \\
contato com os \\
desconfortos \\
experimentados \\
no cotidiano do \\
trabalho, a \\
percepção de que \\
a maneira vigente \\
de fazer ou de \\
pensar é \\
insuficiente ou \\
insatisfatória para \\
dar conta dos \\
desafios do \\
trabalho.
\end{tabular} & $\begin{array}{l}\text { Equipe } \\
\text { multidisciplinar de } \\
\text { saúde indígena }\end{array}$ & \begin{tabular}{|l|} 
Rodas de conversa, \\
trabalhos em grupo \\
e dinâmicas para \\
desenvolver o \\
processo de \\
capacitação dos \\
agentes indígenas \\
de saúde (AIS).
\end{tabular} & \begin{tabular}{|l|} 
São utilizados \\
métodos e \\
processos \\
participativos e \\
problematizadores \\
no processo \\
dialógico de \\
construção e \\
reconstrução \\
compartilhada, \\
fazendo sempre \\
relação entre \\
teoria e prática. \\
Nas capacitações \\
e oficinas há \\
momentos de \\
diálogos, troca de \\
experiências, \\
levantamento de \\
problemas e de \\
soluções nas quais \\
os participantes \\
repensam suas \\
práticas.
\end{tabular} & $\begin{array}{l}\text { Capacitar os } \\
\text { agentes indígenas } \\
\text { de saúde em } \\
\text { técnicas de } \\
\text { transporte e em } \\
\text { como agir em } \\
\text { situações de } \\
\text { emergência, } \\
\text { sempre focando na } \\
\text { prática. }\end{array}$ & $\begin{array}{l}\text { Segundo a } \\
\text { narrativa, os } \\
\text { profissionais que } \\
\text { vivenciam a EPS } \\
\text { têm práticas } \\
\text { diferenciadas e } \\
\text { demonstram mais } \\
\text { motivação para } \\
\text { executar suas } \\
\text { ações. }\end{array}$ \\
\hline
\end{tabular}




\begin{tabular}{|c|c|c|c|c|c|c|c|c|c|}
\hline Narrativas & Local & Início & $\begin{array}{l}\text { Concepção de } \\
\text { educação } \\
\text { destacada no } \\
\text { texto }\end{array}$ & $\begin{array}{l}\text { Inferências a partir } \\
\text { de trechos das } \\
\text { narrativas que } \\
\text { correspondem a } \\
\text { concepções de } \\
\text { educação }\end{array}$ & Participantes & Ações & Método & $\begin{array}{l}\text { Objetivo(s) das } \\
\text { ações }\end{array}$ & $\begin{array}{l}\text { Mudanças } \\
\text { ocorridas }\end{array}$ \\
\hline $\begin{array}{l}\text { "Aprender de um } \\
\text { modo diferente } \\
\text { pode mesmo fazer } \\
\text { a diferença? Novas } \\
\text { reflexões" }\end{array}$ & $\begin{array}{l}\text { Núcleo } \\
\text { Estadual do } \\
\text { Ministério da } \\
\text { Saúde em } \\
\text { Santa Catarina }\end{array}$ & $\begin{array}{c}\text { Não foi } \\
\text { mencionado. }\end{array}$ & $\begin{array}{l}\text { NÃO DECLARADA } \\
\text { EXPRESSAMENTE }\end{array}$ & $\begin{array}{l}\text { Fomentar a troca } \\
\text { de experiências } \\
\text { dentro das } \\
\text { equipes, valorizar } \\
\text { o saber que estas } \\
\text { possuem e, ainda, } \\
\text { enfatizar uma } \\
\text { superação da } \\
\text { fragmentação nos } \\
\text { processos de } \\
\text { trabalho, inclusive } \\
\text { a fragmentação } \\
\text { entre a gestão e a } \\
\text { execução do } \\
\text { trabalho. }\end{array}$ & $\begin{array}{l}\text { Trabalhadores do } \\
\text { Núcleo Estadual do } \\
\text { Ministério da } \\
\text { Saúde em Santa } \\
\text { Catarina }\end{array}$ & $\begin{array}{l}\text { Curso de Sistema } \\
\text { Integrado de } \\
\text { Administração de } \\
\text { Pessoal }\end{array}$ & $\begin{array}{l}\text { Ações } \\
\text { desenvolvidas a } \\
\text { partir da base } \\
\text { conceitual da EPS, } \\
\text { com reflexões no } \\
\text { campo dos } \\
\text { servidores } \\
\text { diretamente } \\
\text { envolvidos na } \\
\text { atenção à saúde. }\end{array}$ & $\begin{array}{l}\text { Reduzir pilhas de } \\
\text { processos } \\
\text { pendentes. }\end{array}$ & $\begin{array}{l}\text { Não foi possível } \\
\text { identificar as } \\
\text { mudanças } \\
\text { ocorridas a partir } \\
\text { da experiência } \\
\text { apresentada na } \\
\text { narrativa. }\end{array}$ \\
\hline $\begin{array}{l}\text { "Aprendizagem no } \\
\text { trabalho: a } \\
\text { experiência da } \\
\text { Coordenação-Geral } \\
\text { de Gestão de } \\
\text { Pessoas em seus } \\
\text { cafés } \\
\text { participativos" }\end{array}$ & $\begin{array}{l}\text { Secretaria- } \\
\text { Executiva do } \\
\text { Ministério da } \\
\text { Saúde }\end{array}$ & $\begin{array}{l}\text { Setembro de } \\
2013\end{array}$ & $\begin{array}{l}\text { NÃO DECLARADA } \\
\text { EXPRESSAMENTE }\end{array}$ & $\begin{array}{l}\text { Destaca aspectos } \\
\text { correlacionados à } \\
\text { Educação } \\
\text { Permanente em } \\
\text { Saúde como: } \\
\text { gestão } \\
\text { compartilhada; } \\
\text { promoção de } \\
\text { espaços efetivos } \\
\text { de gestão } \\
\text { participativa; } \\
\text { integração entre as } \\
\text { equipes; e } \\
\text { melhoria dos } \\
\text { processos de }\end{array}$ & $\begin{array}{l}\text { Trabalhadores da } \\
\text { Coordenação-Geral } \\
\text { de Gestão de } \\
\text { Pessoas (CGESP) } \\
\text { do Ministério da } \\
\text { Saúde }\end{array}$ & \begin{tabular}{|l|} 
Encontros, \\
denominados Cafés \\
Participativos, com \\
todas as equipes da \\
Coordenação-Geral \\
de Gestão de \\
Pessoas.
\end{tabular} & $\begin{array}{l}\text { Nos encontros, } \\
\text { cada trabalhador } \\
\text { tem a } \\
\text { oportunidade de } \\
\text { compartilhar suas } \\
\text { atividades e de } \\
\text { também propor } \\
\text { melhorias para } \\
\text { seus processos de } \\
\text { trabalho e para a } \\
\text { CGESP. }\end{array}$ & $\begin{array}{l}\text { Promoção da } \\
\text { melhoria contínua } \\
\text { dos processos de } \\
\text { trabalho na } \\
\text { perspectiva da } \\
\text { gestão } \\
\text { compartilhada. }\end{array}$ & $\begin{array}{l}\text { Promoção de } \\
\text { espaços efetivos } \\
\text { de gestão } \\
\text { participativa dos } \\
\text { trabalhadores da } \\
\text { CGESP e a } \\
\text { integração entre } \\
\text { as equipes, a } \\
\text { construção de } \\
\text { planos de } \\
\text { trabalho e a } \\
\text { reforma dos } \\
\text { ambientes das } \\
\text { unidades que } \\
\text { compõem a }\end{array}$ \\
\hline
\end{tabular}




\begin{tabular}{|c|c|c|c|c|c|c|c|c|c|}
\hline \multirow[t]{2}{*}{ Narrativas } & \multirow[t]{2}{*}{ Local } & \multirow[t]{2}{*}{ Início } & \multirow[t]{2}{*}{$\begin{array}{l}\text { Concepção de } \\
\text { educação } \\
\text { destacada no } \\
\text { texto }\end{array}$} & \multirow[t]{2}{*}{$\begin{array}{l}\text { Inferências a partir } \\
\text { de trechos das } \\
\text { narrativas que } \\
\text { correspondem a } \\
\text { concepções de } \\
\text { educação } \\
\text { trabalho. }\end{array}$} & Participantes & Ações & \multirow[t]{2}{*}{ Método } & \multirow[t]{2}{*}{$\begin{array}{l}\text { Objetivo(s) das } \\
\text { ações }\end{array}$} & \multirow{2}{*}{$\begin{array}{l}\begin{array}{l}\text { Mudanças } \\
\text { ocorridas }\end{array} \\
\text { Coordenação- } \\
\text { Geral. }\end{array}$} \\
\hline & & & & & & & & & \\
\hline $\begin{array}{l}\text { "Auditoria cidadã: } \\
\text { instrumento de } \\
\text { apoio à gestão do } \\
\text { Sistema Único de } \\
\text { Saúde" }\end{array}$ & $\begin{array}{l}\text { Núcleo } \\
\text { Estadual do } \\
\text { Ministério da } \\
\text { Saúde no Rio } \\
\text { Grande do Sul }\end{array}$ & $\begin{array}{c}\text { Não foi } \\
\text { mencionado. }\end{array}$ & $\begin{array}{l}\text { O procedimento } \\
\text { metodológico } \\
\text { assumido para a } \\
\text { mudança no } \\
\text { processo de } \\
\text { trabalho da } \\
\text { auditoria está } \\
\text { embasado no } \\
\text { compartilhamento } \\
\text { e interação de } \\
\text { tecnologias leve- } \\
\text { duras de Merhy, } \\
\text { entre os técnicos } \\
\text { da auditoria, } \\
\text { gestores e } \\
\text { usuários do SUS } \\
{[\text { [...] }}\end{array}$ & $\begin{array}{l}\text { Destaca que o } \\
\text { método utilizado } \\
\text { para as discussões } \\
\text { que } \\
\text { desencadearam } \\
\text { mudanças no } \\
\text { processo de } \\
\text { trabalho da } \\
\text { auditoria está } \\
\text { embasado no } \\
\text { compartilhamento } \\
\text { e na interação de } \\
\text { tecnologias leve- } \\
\text { duras de Merhy } \\
\text { (2006), com o } \\
\text { envolvimento de } \\
\text { técnicos da } \\
\text { auditoria, gestores } \\
\text { e usuários do SUS. }\end{array}$ & $\begin{array}{l}\text { Trabalhadores do } \\
\text { Serviço de } \\
\text { Auditoria do } \\
\text { Núcleo Estadual do } \\
\text { Ministério da } \\
\text { Saúde no Rio } \\
\text { Grande do Sul. }\end{array}$ & $\begin{array}{l}\text { Organização do } \\
\text { Fórum Estadual } \\
\text { Participativo do } \\
\text { Sistema Nacional } \\
\text { de Auditoria (SNA) } \\
\text { do SUS, no Rio } \\
\text { Grande do Sul, que } \\
\text { tem a previsão de } \\
\text { ocorrer } \\
\text { trimestralmente, } \\
\text { ou seja, quatro } \\
\text { vezes ao ano. }\end{array}$ & \begin{tabular}{|l|} 
O método \\
utilizado para as \\
discussões que \\
desencadearam \\
mudanças no \\
processo de \\
trabalho da \\
auditoria está \\
embasado no \\
compartilhamento \\
e na interação de \\
tecnologias leve- \\
duras de Merhy, \\
com o \\
envolvimento de \\
técnicos da \\
auditoria, gestores \\
e usuários do SUS.
\end{tabular} & $\begin{array}{l}\text { Acompanhar os } \\
\text { avanços da área da } \\
\text { saúde e a } \\
\text { demanda por } \\
\text { direitos sociais. }\end{array}$ & $\begin{array}{l}\text { Não foi possível } \\
\text { identificar as } \\
\text { mudanças } \\
\text { ocorridas a partir } \\
\text { da experiência } \\
\text { apresentada na } \\
\text { narrativa. }\end{array}$ \\
\hline
\end{tabular}




\begin{tabular}{|c|c|c|c|c|c|c|c|c|c|}
\hline Narrativas & Local & Início & $\begin{array}{l}\text { Concepção de } \\
\text { educação } \\
\text { destacada no } \\
\text { texto }\end{array}$ & $\begin{array}{l}\text { Inferências a partir } \\
\text { de trechos das } \\
\text { narrativas que } \\
\text { correspondem a } \\
\text { concepções de } \\
\text { educação }\end{array}$ & Participantes & Ações & Método & $\begin{array}{l}\text { Objetivo(s) das } \\
\text { ações }\end{array}$ & $\begin{array}{l}\text { Mudanças } \\
\text { ocorridas }\end{array}$ \\
\hline $\begin{array}{l}\text { "Avaliação do } \\
\text { processo de } \\
\text { trabalho: atuação } \\
\text { da área técnica de } \\
\text { alimentação e } \\
\text { nutrição na } \\
\text { vigilância alimentar } \\
\text { e nutricional do } \\
\text { DSEI Pernambuco" }\end{array}$ & $\begin{array}{l}\text { Secretaria } \\
\text { Especial de } \\
\text { Saúde Indígena } \\
\text { do Ministério } \\
\text { da Saúde }\end{array}$ & 2012 & $\begin{array}{l}\text { NÃO DECLARADA } \\
\text { EXPRESSAMENTE }\end{array}$ & $\begin{array}{l}\text { Destaca que a ação } \\
\text { desenvolvida é } \\
\text { fundamentada na } \\
\text { problematização e } \\
\text { na dialética } \\
\text { apresentadas na } \\
\text { obra de Paulo } \\
\text { Freire. }\end{array}$ & \begin{tabular}{|l} 
Trabalhadores e \\
agentes indígenas \\
de saúde (AIS) do \\
Distrito Sanitário \\
Especial Indígena \\
(DSEI) de \\
Pernambuco
\end{tabular} & $\begin{array}{l}\text { Atualizações em } \\
\text { vigilância alimentar } \\
\text { e nutricional (VAN) } \\
\text { para os agentes } \\
\text { indígenas de saúde } \\
\text { (AIS) do Distrito } \\
\text { Sanitário Especial } \\
\text { Indígena (DSEI) de } \\
\text { Pernambuco. }\end{array}$ & \begin{tabular}{|l|} 
Atualizações \\
fundamentadas na \\
problematização e \\
na dialética \\
apresentadas na \\
obra de Paulo \\
Freire. \\
Dinâmicas que \\
buscam formas \\
participativas para \\
construção do \\
conhecimento. \\
Construção de \\
materiais \\
educativos tendo \\
como base a \\
estratégia da \\
educação popular \\
em saúde.
\end{tabular} & $\begin{array}{l}\text { Capacitar os } \\
\text { agentes indígenas } \\
\text { de saúde em } \\
\text { vigilância } \\
\text { alimentar e } \\
\text { nutricional. }\end{array}$ & $\begin{array}{l}\text { Segundo a } \\
\text { narrativa, é } \\
\text { possível perceber } \\
\text { resultados da } \\
\text { experiência por } \\
\text { meio da } \\
\text { segurança dos AIS } \\
\text { em temas } \\
\text { específicos da } \\
\text { vigilância } \\
\text { alimentar e } \\
\text { nutricional, a } \\
\text { exemplo da } \\
\text { classificação do } \\
\text { estado nutricional } \\
\text { e do uso de curvas } \\
\text { do cartão da } \\
\text { criança. }\end{array}$ \\
\hline
\end{tabular}




\begin{tabular}{|c|c|c|c|c|c|c|c|c|c|}
\hline Narrativas & Local & Início & $\begin{array}{l}\text { Concepção de } \\
\text { educação } \\
\text { destacada no } \\
\text { texto }\end{array}$ & $\begin{array}{l}\text { Inferências a partir } \\
\text { de trechos das } \\
\text { narrativas que } \\
\text { correspondem a } \\
\text { concepções de } \\
\text { educação }\end{array}$ & Participantes & Ações & Método & $\begin{array}{l}\text { Objetivo(s) das } \\
\text { ações }\end{array}$ & $\begin{array}{l}\text { Mudanças } \\
\text { ocorridas }\end{array}$ \\
\hline $\begin{array}{l}\text { "Capacitação das } \\
\text { equipes } \\
\text { multidisciplinares } \\
\text { de saúde indígena, } \\
\text { lideranças e } \\
\text { professores para } \\
\text { atuação na saúde } \\
\text { mental dos povos } \\
\text { indígenas com } \\
\text { ênfase no uso } \\
\text { indevido de drogas } \\
\text { lícitas e ilícitas no } \\
\text { DSEI Ceará" }\end{array}$ & $\begin{array}{l}\text { Secretaria } \\
\text { Especial de } \\
\text { Saúde Indígena } \\
\text { do Ministério } \\
\text { da Saúde }\end{array}$ & $\begin{array}{c}\text { Não foi } \\
\text { mencionado. }\end{array}$ & $\begin{array}{l}\text { A estratégia de } \\
\text { Educação } \\
\text { Permanente em } \\
\text { Saúde das equipes } \\
\text { multidisciplinares } \\
\text { de saúde indígena } \\
\text { (EMSI) em saúde } \\
\text { mental no Ceará } \\
\text { busca associar } \\
\text { conhecimentos } \\
\text { teóricos às } \\
\text { atividades de } \\
\text { práticas descritas } \\
\text { pelos participantes } \\
\text { junto aos } \\
\text { principais atores } \\
\text { da comunidade e, } \\
\text { de modo sinérgico, } \\
\text { desenvolver ações } \\
\text { de promoção e } \\
\text { prevenção do uso } \\
\text { de drogas lícitas e } \\
\text { ilícitas. }\end{array}$ & $\begin{array}{l}\text { Destaca a } \\
\text { associação de } \\
\text { conhecimentos } \\
\text { teóricos às } \\
\text { atividades de } \\
\text { práticas e também } \\
\text { o estímulo ao } \\
\text { protagonismo } \\
\text { social. }\end{array}$ & $\begin{array}{l}\text { Equipes } \\
\text { multidisciplinares } \\
\text { de saúde indígena } \\
\text { no Ceará }\end{array}$ & $\begin{array}{l}\text { Criação de cordéis, } \\
\text { canções, versos e } \\
\text { dramas para a } \\
\text { disseminação das } \\
\text { informações nas } \\
\text { comunidades. }\end{array}$ & \begin{tabular}{|l} 
Associação de \\
conhecimentos \\
teóricos às \\
atividades de \\
práticas descritas \\
pelos \\
participantes com \\
os principais \\
atores da \\
comunidade. \\
Elaboração de um \\
plano de ação, \\
valorizando \\
conhecimentos \\
tradicionais, \\
utilizando meios \\
de produção \\
espontâneos \\
(cordéis, canções, \\
versos e dramas).
\end{tabular} & $\begin{array}{l}\text { Desenvolver ações } \\
\text { de promoção e } \\
\text { prevenção do uso } \\
\text { de drogas lícitas e } \\
\text { ilíitas por meio da } \\
\text { capacitação das } \\
\text { equipes } \\
\text { multidisciplinares } \\
\text { de saúde indígena, } \\
\text { favorecendo o } \\
\text { diálogo e a } \\
\text { integração para } \\
\text { enfrentamento do } \\
\text { problema. }\end{array}$ & $\begin{array}{l}\text { Segundo a } \\
\text { narrativa, os } \\
\text { participantes das } \\
\text { capacitações } \\
\text { interagiram } \\
\text { positivamente, } \\
\text { introduzindo } \\
\text { saberes e } \\
\text { permitindo a } \\
\text { troca de } \\
\text { informações e } \\
\text { compartilhamento } \\
\text { de experiências. }\end{array}$ \\
\hline $\begin{array}{l}\text { "Ciclo de Educação } \\
\text { Permanente em } \\
\text { Saúde em } \\
\text { odontologia na } \\
\text { CASAI Macapá" }\end{array}$ & $\begin{array}{l}\text { Secretaria } \\
\text { Especial de } \\
\text { Saúde Indígena } \\
\text { do Ministério } \\
\text { da Saúde }\end{array}$ & $\begin{array}{c}\text { Não foi } \\
\text { mencionado. }\end{array}$ & $\begin{array}{l}\text { NÃO DECLARADA } \\
\text { EXPRESSAMENTE }\end{array}$ & $\begin{array}{l}\text { Destaca a } \\
\text { relevância da } \\
\text { discussão sobre os } \\
\text { conceitos de EP e } \\
\text { Educação } \\
\text { Continuada } \\
\text { realizada durante a }\end{array}$ & $\begin{array}{l}\text { Não fica claro na } \\
\text { narrativa, quem } \\
\text { são os } \\
\text { participantes da } \\
\text { ação desenvolvida. }\end{array}$ & $\begin{array}{l}\text { Não são detalhadas } \\
\text { na narrativa as } \\
\text { ações } \\
\text { desenvolvidas. }\end{array}$ & \begin{tabular}{|l|} 
Não são \\
apresentados os \\
métodos \\
utilizados na \\
experiência \\
relatada.
\end{tabular} & $\begin{array}{l}\text { Não se percebe os } \\
\text { objetivos das } \\
\text { ações na narrativa. }\end{array}$ & $\begin{array}{l}\text { Não foi possível } \\
\text { identificar as } \\
\text { mudanças } \\
\text { ocorridas a partir } \\
\text { da experiência } \\
\text { apresentada na } \\
\text { narrativa. }\end{array}$ \\
\hline
\end{tabular}




\begin{tabular}{|c|c|c|c|c|c|c|c|c|c|}
\hline Narrativas & Local & Início & $\begin{array}{l}\text { Concepção de } \\
\text { educação } \\
\text { destacada no } \\
\text { texto }\end{array}$ & $\begin{array}{l}\text { Inferências a partir } \\
\text { de trechos das } \\
\text { narrativas que } \\
\text { correspondem a } \\
\text { concepções de } \\
\text { educação }\end{array}$ & Participantes & Ações & Método & $\begin{array}{l}\text { Objetivo(s) das } \\
\text { ações }\end{array}$ & $\begin{array}{l}\text { Mudanças } \\
\text { ocorridas }\end{array}$ \\
\hline & & & & $\begin{array}{l}\text { Mostra e destaca } \\
\text { que o ambiente de } \\
\text { trabalho deve nos } \\
\text { levar à busca de } \\
\text { novos } \\
\text { conhecimentos } \\
\text { para melhorar os } \\
\text { processos de } \\
\text { trabalho. }\end{array}$ & & & & & \\
\hline $\begin{array}{l}\text { "Coletivo MS: } \\
\text { projeto de } \\
\text { valorização do } \\
\text { trabalho e dos } \\
\text { trabalhadores do } \\
\text { Ministério da } \\
\text { Saúde" }\end{array}$ & $\begin{array}{l}\text { Secretaria- } \\
\text { Executiva do } \\
\text { Ministério da } \\
\text { Saúde }\end{array}$ & $\begin{array}{c}\text { Não foi } \\
\text { mencionado. }\end{array}$ & $\begin{array}{l}\text { [...] Educação } \\
\text { Permanente em } \\
\text { Saúde é um } \\
\text { potente } \\
\text { disparador de } \\
\text { processos } \\
\text { coletivos [...] }\end{array}$ & $\begin{array}{l}\text { Potente disparador } \\
\text { de processos } \\
\text { coletivos que } \\
\text { possibilita } \\
\text { construir, de forma } \\
\text { compartilhada, } \\
\text { novos modos de se } \\
\text { fazer as políticas } \\
\text { do Ministério da } \\
\text { Saúde, valorizando } \\
\text { e reconhecendo o } \\
\text { potencial } \\
\text { inventivo, ético e } \\
\text { político dos } \\
\text { sujeitos, com vista } \\
\text { à inovação nos } \\
\text { processos de } \\
\text { trabalho e } \\
\text { consequente } \\
\text { melhoria dos } \\
\text { resultados }\end{array}$ & $\begin{array}{l}\text { Trabalhadores do } \\
\text { Ministério da } \\
\text { Saúde }\end{array}$ & \begin{tabular}{|l} 
Não foram \\
apresentadas na \\
narrativa as ações \\
desenvolvidas.
\end{tabular} & $\begin{array}{l}\text { Não foi } \\
\text { apresentado o } \\
\text { método utilizado. }\end{array}$ & $\begin{array}{l}\text { As ações } \\
\text { desenvolvidas no } \\
\text { âmbito do Projeto } \\
\text { de valorização do } \\
\text { trabalho e do } \\
\text { trabalhador do } \\
\text { Ministério da } \\
\text { Saúde - Coletivo } \\
\text { MS têm como } \\
\text { perspectiva } \\
\text { melhorar os canais } \\
\text { de comunicação, } \\
\text { promover a } \\
\text { contínua } \\
\text { articulação e } \\
\text { integração das } \\
\text { diversas equipes e } \\
\text { aprimorar a gestão } \\
\text { com a contribuição } \\
\text { dos trabalhadores } \\
\text { do Ministério da }\end{array}$ & $\begin{array}{l}\text { Não foi possível } \\
\text { identificar as } \\
\text { mudanças } \\
\text { ocorridas a partir } \\
\text { da experiência } \\
\text { apresentada na } \\
\text { narrativa. }\end{array}$ \\
\hline
\end{tabular}




\begin{tabular}{|c|c|c|c|c|c|c|c|c|c|}
\hline Narrativas & Local & Início & $\begin{array}{l}\text { Concepção de } \\
\text { educação } \\
\text { destacada no } \\
\text { texto }\end{array}$ & $\begin{array}{l}\text { Inferências a partir } \\
\text { de trechos das } \\
\text { narrativas que } \\
\text { correspondem a } \\
\text { concepções de } \\
\text { educação }\end{array}$ & Participantes & Ações & Método & $\begin{array}{l}\text { Objetivo(s) das } \\
\text { ações }\end{array}$ & $\begin{array}{l}\text { Mudanças } \\
\text { ocorridas }\end{array}$ \\
\hline & & & & $\begin{array}{l}\text { entregues à } \\
\text { sociedade. }\end{array}$ & & & & $\begin{array}{l}\text { Saúde. Também se } \\
\text { apresenta como } \\
\text { objetivo da ação, } \\
\text { potencializar os } \\
\text { movimentos } \\
\text { participativos no } \\
\text { MS. }\end{array}$ & \\
\hline $\begin{array}{l}\text { "Construção } \\
\text { coletiva das metas } \\
\text { e indicadores de } \\
\text { avaliação de } \\
\text { desempenho das } \\
\text { equipes da } \\
\text { Coordenação-Geral } \\
\text { de Gestão de } \\
\text { Pessoas" }\end{array}$ & $\begin{array}{l}\text { Secretaria- } \\
\text { Executiva do } \\
\text { Ministério da } \\
\text { Saúde }\end{array}$ & $2012-2013$ & $\begin{array}{l}\text { NÃO DECLARADA } \\
\text { EXPRESSAMENTE }\end{array}$ & $\begin{array}{l}\text { Destaca aspectos } \\
\text { correlacionados à } \\
\text { Educação } \\
\text { Permanente em } \\
\text { Saúde como: } \\
\text { construção } \\
\text { coletiva, por } \\
\text { exemplo. }\end{array}$ & $\begin{array}{l}\text { Trabalhadores da } \\
\text { Coordenação-Geral } \\
\text { de Gestão de } \\
\text { Pessoas (CGESP) } \\
\text { do Ministério da } \\
\text { Saúde }\end{array}$ & $\begin{array}{l}\text { Criação de espaços } \\
\text { de diálogos e de } \\
\text { construção } \\
\text { coletiva. }\end{array}$ & $\begin{array}{l}\text { A estratégia de } \\
\text { construção de } \\
\text { metas por equipes } \\
\text { de trabalho foi } \\
\text { pactuada no } \\
\text { Colegiado Gestor } \\
\text { da Coordenação- } \\
\text { Geral de Gestão } \\
\text { de Pessoas. }\end{array}$ & \begin{tabular}{|l|} 
Construção \\
coletiva de metas \\
para avaliação de \\
desempenho no \\
ciclo 2012-2013.
\end{tabular} & $\begin{array}{l}\text { Composição de } \\
\text { um conjunto de } \\
\text { metas de cada } \\
\text { área e do Painel } \\
\text { de Metas de } \\
\text { Avaliação de } \\
\text { Desempenho da } \\
\text { CGESP; } \\
\text { Promoção de um } \\
\text { processo de } \\
\text { aprendizagem e } \\
\text { de } \\
\text { amadurecimento } \\
\text { das equipes de } \\
\text { trabalho. }\end{array}$ \\
\hline
\end{tabular}




\begin{tabular}{|c|c|c|c|c|c|c|c|c|c|}
\hline Narrativas & Local & Início & $\begin{array}{c}\text { Concepção de } \\
\text { educação } \\
\text { destacada no } \\
\text { texto }\end{array}$ & $\begin{array}{l}\text { Inferências a partir } \\
\text { de trechos das } \\
\text { narrativas que } \\
\text { correspondem a } \\
\text { concepções de } \\
\text { educação }\end{array}$ & Participantes & Ações & Método & $\begin{array}{l}\text { Objetivo(s) das } \\
\text { ações }\end{array}$ & $\begin{array}{c}\text { Mudanças } \\
\text { ocorridas }\end{array}$ \\
\hline $\begin{array}{l}\text { "Curso de } \\
\text { educação a } \\
\text { distância saber } \\
\text { saúde: prevenção } \\
\text { do tabagismo e de } \\
\text { outros fatores de } \\
\text { risco para o } \\
\text { desenvolvimento } \\
\text { de doenças } \\
\text { crônicas não } \\
\text { transmissíveis" }\end{array}$ & $\begin{array}{l}\text { Instituto } \\
\text { Nacional de } \\
\text { Câncer - Rio de } \\
\text { Janeiro }\end{array}$ & 2012 & $\begin{array}{l}\text { [...] o local de } \\
\text { trabalho deve ser } \\
\text { visto sempre como } \\
\text { um espaço de } \\
\text { aprendizado, troca } \\
\text { e interação [...] }\end{array}$ & \begin{tabular}{|l|} 
"... o local de \\
trabalho deve ser \\
visto sempre como \\
um espaço de \\
aprendizado, troca \\
e interação... o \\
planejamento \\
conjunto entre \\
saúde e educação \\
é requisito \\
indispensável para \\
o desenvolvimento \\
de ações de \\
promoção da \\
saúde nas escolas."
\end{tabular} & $\begin{array}{l}\text { Profissionais da } \\
\text { Saúde e da } \\
\text { Educação }\end{array}$ & $\begin{array}{l}\text { Curso de educação } \\
\text { a distância Saber } \\
\text { saúde - prevenção } \\
\text { do tabagismo e de } \\
\text { outros fatores de } \\
\text { risco de doenças } \\
\text { crônicas não } \\
\text { transmissíveis. }\end{array}$ & \begin{tabular}{|l} 
Por meio do curso \\
a distância, os \\
profissionais de \\
saúde e da \\
educação \\
compartilham \\
conhecimentos \\
que contribuem \\
para a prevenção \\
do câncer.
\end{tabular} & $\begin{array}{l}\text { Oferecer subsídios } \\
\text { aos profissionais } \\
\text { da Saúde e da } \\
\text { Educação para que } \\
\text { trabalhem, em } \\
\text { escolas, processos } \\
\text { pedagógicos } \\
\text { voltados à } \\
\text { prevenção do } \\
\text { tabagismo e de } \\
\text { outros fatores de } \\
\text { risco para doenças } \\
\text { crônicas não } \\
\text { transmissíveis, } \\
\text { entre elas, o } \\
\text { câncer. }\end{array}$ & \begin{tabular}{|l} 
Segundo a \\
narrativa, foram \\
formados até a \\
data de realização \\
da Mostra, 1.390 \\
trabalhadores que \\
indicaram ter sido \\
o curso \\
extremamente \\
relevante para sua \\
formação pessoal \\
e profissional.
\end{tabular} \\
\hline
\end{tabular}




\begin{tabular}{|c|c|c|c|c|c|c|c|c|c|}
\hline Narrativas & Local & Início & $\begin{array}{l}\text { Concepção de } \\
\text { educação } \\
\text { destacada no } \\
\text { texto }\end{array}$ & $\begin{array}{l}\text { Inferências a partir } \\
\text { de trechos das } \\
\text { narrativas que } \\
\text { correspondem a } \\
\text { concepções de } \\
\text { educação }\end{array}$ & Participantes & Ações & Método & $\begin{array}{l}\text { Objetivo(s) das } \\
\text { ações }\end{array}$ & $\begin{array}{l}\text { Mudanças } \\
\text { ocorridas }\end{array}$ \\
\hline $\begin{array}{l}\text { "Educação } \\
\text { Permanente em } \\
\text { Saúde: uma } \\
\text { ferramenta para a } \\
\text { formação" }\end{array}$ & $\begin{array}{l}\text { Secretaria } \\
\text { Especial de } \\
\text { Saúde Indígena } \\
\text { do Ministério } \\
\text { da Saúde }\end{array}$ & $\begin{array}{c}\text { Não foi } \\
\text { mencionado. }\end{array}$ & $\begin{array}{l}\text { [...] EPS como } \\
\text { política que } \\
\text { orienta a formação } \\
\text { e a qualificação } \\
\text { dos trabalhadores } \\
{[\ldots . .]}\end{array}$ & $\begin{array}{l}\text { EPS: política que } \\
\text { orienta a formação } \\
\text { e a qualificação } \\
\text { dos trabalhadores. }\end{array}$ & \begin{tabular}{|l|} 
Servidores do \\
Distrito Sanitário \\
Especial Indígena \\
MG/ES em parceria \\
com as equipes \\
multidisciplinares \\
de saúde indígena.
\end{tabular} & $\begin{array}{l}\text { Oficinas sobre } \\
\text { temas que } \\
\text { perpassam o } \\
\text { cotidiano de } \\
\text { trabalho dos } \\
\text { agentes indígenas } \\
\text { de saneamento } \\
\text { (Aisan). }\end{array}$ & \begin{tabular}{|l|} 
Oficinas para \\
discussão sobre \\
temas de saúde e \\
troca de \\
conhecimentos.
\end{tabular} & $\begin{array}{l}\text { Qualificar as } \\
\text { atividades dos } \\
\text { Aisans e dos } \\
\text { agentes indígenas } \\
\text { de saúde. }\end{array}$ & $\begin{array}{l}\text { As oficinas } \\
\text { possibilitam novos } \\
\text { olhares sobre } \\
\text { determinados } \\
\text { temas, trazem } \\
\text { novos conteúdos, } \\
\text { com momentos } \\
\text { de troca de } \\
\text { conhecimentos } \\
\text { entre os Aisans e } \\
\text { os demais } \\
\text { profissionais das } \\
\text { equipes de saúde } \\
\text { indígena. }\end{array}$ \\
\hline $\begin{array}{l}\text { "Educação } \\
\text { Permanente em } \\
\text { Saúde dos } \\
\text { profissionais } \\
\text { participantes do } \\
\text { programa Mais } \\
\text { Médicos para o } \\
\text { Brasil no Tocantins: } \\
\text { uma estratégia } \\
\text { imprescindível } \\
\text { para o } \\
\text { fortalecimento da } \\
\text { atenção primária } \\
\text { no estado" }\end{array}$ & $\begin{array}{l}\text { Secretaria de } \\
\text { Gestão do } \\
\text { Trabalho e da } \\
\text { Educação na } \\
\text { Saúde do } \\
\text { Ministério da } \\
\text { Saúde }\end{array}$ & 2014 & $\begin{array}{l}{[\ldots . .] \text { processos de }} \\
\text { ensino- } \\
\text { aprendizagem } \\
\text { condizentes com a } \\
\text { realidade e } \\
\text { demandas do } \\
\text { território [...] }\end{array}$ & \begin{tabular}{|l} 
Apresenta \\
aspectos \\
correlacionados às \\
metodologias \\
utilizadas na \\
Educação \\
Permanente em \\
Saúde.
\end{tabular} & \begin{tabular}{|l|} 
Profissionais \\
participantes do \\
programa Mais \\
Médicos para o \\
Brasil no Tocantins.
\end{tabular} & $\begin{array}{l}\text { Oficinas, cursos, } \\
\text { rodas de conversa }\end{array}$ & $\begin{array}{l}\text { Organização de } \\
\text { ações/ processos } \\
\text { de ensino- } \\
\text { aprendizagem } \\
\text { condizentes com a } \\
\text { realidade e } \\
\text { demandas do } \\
\text { território. }\end{array}$ & $\begin{array}{l}\text { Integração, } \\
\text { compartilhamento, } \\
\text { ensino e } \\
\text { aprendizagem dos } \\
\text { participantes do } \\
\text { programa Mais } \\
\text { Médicos para o } \\
\text { Brasil no } \\
\text { Tocantins. }\end{array}$ & $\begin{array}{l}\text { Não foi possível } \\
\text { identificar as } \\
\text { mudanças } \\
\text { ocorridas a partir } \\
\text { da experiência } \\
\text { apresentada na } \\
\text { narrativa. }\end{array}$ \\
\hline
\end{tabular}




\begin{tabular}{|c|c|c|c|c|c|c|c|c|c|}
\hline Narrativas & Local & Início & $\begin{array}{l}\text { Concepção de } \\
\text { educação } \\
\text { destacada no } \\
\text { texto }\end{array}$ & $\begin{array}{l}\text { Inferências a partir } \\
\text { de trechos das } \\
\text { narrativas que } \\
\text { correspondem a } \\
\text { concepções de } \\
\text { educação }\end{array}$ & Participantes & Ações & Método & $\begin{array}{l}\text { Objetivo(s) das } \\
\text { ações }\end{array}$ & $\begin{array}{l}\text { Mudanças } \\
\text { ocorridas }\end{array}$ \\
\hline $\begin{array}{l}\text { "Educação } \\
\text { permanente em } \\
\text { cuidados } \\
\text { paliativos: relato } \\
\text { de experiência no } \\
\text { Instituto Nacional } \\
\text { de Câncer José } \\
\text { Alencar Gomes da } \\
\text { Silva" }\end{array}$ & $\begin{array}{l}\text { Instituto } \\
\text { Nacional de } \\
\text { Câncer - Rio de } \\
\text { Janeiro }\end{array}$ & 2011 & $\begin{array}{l}\text { NÃO DECLARADA } \\
\text { EXPRESSAMENTE }\end{array}$ & $\begin{array}{l}\text { Apresenta } \\
\text { aspectos } \\
\text { correlacionados à } \\
\text { Educação } \\
\text { Permanente em } \\
\text { Saúde. }\end{array}$ & \begin{tabular}{|l|} 
Equipe de \\
enfermagem do \\
Instituto Nacional \\
de Câncer.
\end{tabular} & $\begin{array}{l}\text { Discussões com a } \\
\text { equipe para } \\
\text { melhorar a } \\
\text { educação e o } \\
\text { aprendizado } \\
\text { dentro da } \\
\text { instituição. }\end{array}$ & $\begin{array}{l}\text { Várias caixas de } \\
\text { sugestões foram } \\
\text { disponibilizadas } \\
\text { em cada setor do } \\
\text { hospital. Em } \\
\text { seguida, foi } \\
\text { realizada uma } \\
\text { reunião para } \\
\text { debater as } \\
\text { propostas. }\end{array}$ & $\begin{array}{l}\text { Promover a } \\
\text { reflexão sobre os } \\
\text { problemas e ir até } \\
\text { as equipes para } \\
\text { saber o que elas } \\
\text { desejavam ou } \\
\text { esperavam de } \\
\text { Educação } \\
\text { Permanente em } \\
\text { Saúde. }\end{array}$ & $\begin{array}{l}\text { Constatou-se } \\
\text { maior interação } \\
\text { entre as equipes. }\end{array}$ \\
\hline $\begin{array}{l}\text { "Educação } \\
\text { permanente para o } \\
\text { controle social" }\end{array}$ & $\begin{array}{l}\text { Núcleo } \\
\text { Estadual do } \\
\text { Ministério da } \\
\text { Saúde no Pará }\end{array}$ & 2014 & $\begin{array}{l}\text { NÃO DECLARADA } \\
\text { EXPRESSAMENTE }\end{array}$ & $\begin{array}{l}\text { Destaca: "... } \\
\text { Compartilhar e } \\
\text { aprender com } \\
\text { outras práticas me } \\
\text { fazem crer que } \\
\text { estamos no } \\
\text { caminho certo". }\end{array}$ & $\begin{array}{l}\text { Não fica claro na } \\
\text { narrativa, quem } \\
\text { são os } \\
\text { participantes da } \\
\text { ação desenvolvida. }\end{array}$ & $\begin{array}{l}\text { Criação do Fórum } \\
\text { de Educação } \\
\text { Permanente em } \\
\text { Saúde no Pará } \\
\text { (Feps) }\end{array}$ & $\begin{array}{l}\text { Não se percebe o } \\
\text { método na } \\
\text { narrativa. }\end{array}$ & $\begin{array}{l}\text { Fortalecer o } \\
\text { controle social por } \\
\text { meio da troca de } \\
\text { conhecimentos, } \\
\text { utilizando a } \\
\text { educação popular } \\
\text { e a EPS, } \\
\text { estimulando a } \\
\text { ampliação da visão } \\
\text { crítica e a } \\
\text { participação mais } \\
\text { atuante da } \\
\text { sociedade. }\end{array}$ & $\begin{array}{l}\text { Não foi possível } \\
\text { identificar as } \\
\text { mudanças } \\
\text { ocorridas a partir } \\
\text { da experiência } \\
\text { apresentada na } \\
\text { narrativa. }\end{array}$ \\
\hline
\end{tabular}




\begin{tabular}{|c|c|c|c|c|c|c|c|c|c|}
\hline Narrativas & Local & Início & $\begin{array}{l}\text { Concepção de } \\
\text { educação } \\
\text { destacada no } \\
\text { texto }\end{array}$ & $\begin{array}{l}\text { Inferências a partir } \\
\text { de trechos das } \\
\text { narrativas que } \\
\text { correspondem a } \\
\text { concepções de } \\
\text { educação }\end{array}$ & Participantes & Ações & Método & $\begin{array}{l}\text { Objetivo(s) das } \\
\text { ações }\end{array}$ & $\begin{array}{l}\text { Mudanças } \\
\text { ocorridas }\end{array}$ \\
\hline $\begin{array}{l}\text { "Educação } \\
\text { Permanente em } \\
\text { Saúde por meio do } \\
\text { projeto } \\
\text { compartilhando o } \\
\text { conhecimento" }\end{array}$ & $\begin{array}{l}\text { Núcleo } \\
\text { Estadual do } \\
\text { Ministério da } \\
\text { Saúde no Ceará }\end{array}$ & $\begin{array}{c}\text { Não foi } \\
\text { mencionado. }\end{array}$ & $\begin{array}{l}\text { [...] qualificar os } \\
\text { processos de } \\
\text { trabalho e } \\
\text { possibilitar } \\
\text { interação mais } \\
\text { dinâmica entre os } \\
\text { servidores, com } \\
\text { consequente } \\
\text { melhora nas } \\
\text { relações no } \\
\text { ambiente de } \\
\text { trabalho. }\end{array}$ & \begin{tabular}{|l} 
Destaca termos \\
relacionados à \\
Educação \\
Permanente em \\
Saúde, como a \\
utilização de \\
metodologias \\
como roda de \\
conversa, café com \\
ideias, entre \\
outras de forma a \\
garantir a melhoria \\
dos processos de \\
trabalho, a \\
valorização do \\
conhecimento, o \\
desenvolvimento \\
de novas \\
competências e a \\
integração das \\
diversas áreas do \\
Núcleo Estadual.
\end{tabular} & \begin{tabular}{|l|} 
Servidores do \\
Núcleo Estadual do \\
Ministério da \\
Saúde no Ceará.
\end{tabular} & \begin{tabular}{|l} 
Roda de conversa, \\
café com ideias, \\
MS participativo, \\
projetos de \\
integração social.
\end{tabular} & $\begin{array}{l}\text { Não foi } \\
\text { apresentado o } \\
\text { método utilizado. }\end{array}$ & $\begin{array}{l}\text { Garantir a melhora } \\
\text { dos processos de } \\
\text { trabalho, a } \\
\text { valorização do } \\
\text { conhecimento, o } \\
\text { desenvolvimento } \\
\text { de novas } \\
\text { competências e a } \\
\text { integração das } \\
\text { diversas áreas que } \\
\text { compõem o } \\
\text { Serviço de Gestão } \\
\text { Administrativa do } \\
\text { Núcleo Estadual do } \\
\text { Ministério da } \\
\text { Saúde no Ceará. }\end{array}$ & $\begin{array}{l}\text { Possíveis } \\
\text { resultados: } \\
\text { qualificação dos } \\
\text { processos de } \\
\text { trabalho, } \\
\text { possibilitando } \\
\text { interação mais } \\
\text { dinâmica entre os } \\
\text { servidores e } \\
\text { melhora nas } \\
\text { relações no } \\
\text { ambiente de } \\
\text { trabalho. }\end{array}$ \\
\hline
\end{tabular}




\begin{tabular}{|c|c|c|c|c|c|c|c|c|c|}
\hline Narrativas & Local & Início & $\begin{array}{l}\text { Concepção de } \\
\text { educação } \\
\text { destacada no } \\
\text { texto }\end{array}$ & $\begin{array}{l}\text { Inferências a partir } \\
\text { de trechos das } \\
\text { narrativas que } \\
\text { correspondem a } \\
\text { concepções de } \\
\text { educação }\end{array}$ & Participantes & Ações & Método & $\begin{array}{l}\text { Objetivo(s) das } \\
\text { ações }\end{array}$ & $\begin{array}{l}\text { Mudanças } \\
\text { ocorridas }\end{array}$ \\
\hline $\begin{array}{l}\text { "Elaboração de } \\
\text { material } \\
\text { instrucional de } \\
\text { auditoria para } \\
\text { qualificação dos } \\
\text { profissionais do } \\
\text { Sistema Nacional } \\
\text { de Auditoria do } \\
\text { SUS" }\end{array}$ & $\begin{array}{l}\text { Secretaria de } \\
\text { Gestão } \\
\text { Estratégica e } \\
\text { Participativa do } \\
\text { Ministério da } \\
\text { Saúde }\end{array}$ & $\begin{array}{c}\text { Não foi } \\
\text { mencionado. }\end{array}$ & $\begin{array}{l}\text { "Os cursos de } \\
\text { formação são } \\
\text { componentes de } \\
\text { processos de } \\
\text { educação } \\
\text { continuada. O } \\
\text { processo de } \\
\text { preparação do } \\
\text { material para } \\
\text { esses cursos se } \\
\text { constituiu em } \\
\text { momentos de } \\
\text { educação } \\
\text { permanente." }\end{array}$ & $\begin{array}{l}\text { Destaca elementos } \\
\text { correlacionados à } \\
\text { Educação } \\
\text { Permanente em } \\
\text { Saúde como } \\
\text { reflexão sobre a } \\
\text { prática, tomar } \\
\text { como ponto de } \\
\text { partida o } \\
\text { conhecimento } \\
\text { cotidiano do } \\
\text { trabalho... }\end{array}$ & $\begin{array}{l}\text { Representantes } \\
\text { dos componentes } \\
\text { federal, estaduais } \\
\text { e municipais do } \\
\text { Sistema Nacional } \\
\text { de Auditoria. }\end{array}$ & $\begin{array}{l}\text { Grupos de } \\
\text { trabalho. }\end{array}$ & $\begin{array}{l}\text { Formado um } \\
\text { grupo de trabalho } \\
\text { para refletir sobre } \\
\text { a prática de } \\
\text { auditoria do SUS e } \\
\text { construir } \\
\text { coletivamente } \\
\text { material didático } \\
\text { para técnicos em } \\
\text { auditoria do SUS, } \\
\text { fundamentado na } \\
\text { reflexão crítica } \\
\text { dos processos de } \\
\text { trabalho e nas } \\
\text { práticas das } \\
\text { equipes de } \\
\text { auditoria. "Para a } \\
\text { transformação } \\
\text { dessas práticas, } \\
\text { tomou-se como } \\
\text { ponto de partida o } \\
\text { conhecimento } \\
\text { cotidiano do } \\
\text { trabalho dos } \\
\text { auditores do SUS." }\end{array}$ & $\begin{array}{l}\text { Capacitação dos } \\
\text { profissionais do } \\
\text { Sistema Nacional } \\
\text { de Auditoria do } \\
\text { SUS. }\end{array}$ & $\begin{array}{l}\text { Não foi possível } \\
\text { identificar as } \\
\text { mudanças } \\
\text { ocorridas a partir } \\
\text { da experiência } \\
\text { apresentada na } \\
\text { narrativa. }\end{array}$ \\
\hline
\end{tabular}




\begin{tabular}{|c|c|c|c|c|c|c|c|c|c|}
\hline Narrativas & Local & Início & $\begin{array}{l}\text { Concepção de } \\
\text { educação } \\
\text { destacada no } \\
\text { texto }\end{array}$ & $\begin{array}{l}\text { Inferências a partir } \\
\text { de trechos das } \\
\text { narrativas que } \\
\text { correspondem a } \\
\text { concepções de } \\
\text { educação }\end{array}$ & Participantes & Ações & Método & $\begin{array}{l}\text { Objetivo(s) das } \\
\text { ações }\end{array}$ & $\begin{array}{l}\text { Mudanças } \\
\text { ocorridas }\end{array}$ \\
\hline $\begin{array}{l}\text { "Encantos da roda } \\
\text { e vivências da } \\
\text { estratégia } \\
\text { brasileirinhas e } \\
\text { brasileirinhos } \\
\text { saudáveis" }\end{array}$ & $\begin{array}{l}\text { Fundação } \\
\text { Oswaldo Cruz }\end{array}$ & $\begin{array}{c}\text { Não foi } \\
\text { mencionado. }\end{array}$ & $\begin{array}{l}\text { "Na Educação } \\
\text { Permanente em } \\
\text { Saúde, a ação de } \\
\text { formação- } \\
\text { intervenção, a } \\
\text { utilização da } \\
\text { cartografia como } \\
\text { método, a noção } \\
\text { de grupalidade } \\
\text { como dispositivo e } \\
\text { a dimensão ética } \\
\text { do cuidado } \\
\text { resultaram em } \\
\text { transformações } \\
\text { positivas, com } \\
\text { melhor } \\
\text { compreensão da } \\
\text { subjetividade do } \\
\text { trabalho vivo em } \\
\text { saúde, que são } \\
\text { pontos fortes para } \\
\text { viabilizar um } \\
\text { trabalho mais } \\
\text { qualitativo no } \\
\text { âmbito do SUS, o } \\
\text { saber cuidar." }\end{array}$ & $\begin{array}{l}\text { Destaca termos } \\
\text { como "trabalho } \\
\text { vivo em saúde" } \\
\text { utilizados nas } \\
\text { concepções de } \\
\text { Educação } \\
\text { Permanente em } \\
\text { Saúde. }\end{array}$ & $\begin{array}{l}\text { Consultores } \\
\text { estaduais de saúde } \\
\text { da criança. }\end{array}$ & $\begin{array}{l}\text { Não são detalhadas } \\
\text { na narrativa as } \\
\text { ações } \\
\text { desenvolvidas. }\end{array}$ & $\begin{array}{l}\text { A cartografia foi } \\
\text { utilizada como } \\
\text { método. }\end{array}$ & $\begin{array}{l}\text { Fortalecimento de } \\
\text { ações e políticas } \\
\text { públicas voltadas } \\
\text { para a primeira } \\
\text { infância. }\end{array}$ & $\begin{array}{l}\text { Transformações } \\
\text { positivas, com } \\
\text { melhor } \\
\text { compreensão da } \\
\text { subjetividade do } \\
\text { trabalho vivo em } \\
\text { saúde, que são } \\
\text { pontos fortes para } \\
\text { viabilizar um } \\
\text { trabalho mais } \\
\text { qualitativo no } \\
\text { âmbito do } \\
\text { Sistema Único de } \\
\text { Saúde. }\end{array}$ \\
\hline
\end{tabular}




\begin{tabular}{|c|c|c|c|c|c|c|c|c|c|}
\hline Narrativas & Local & Início & $\begin{array}{c}\text { Concepção de } \\
\text { educação } \\
\text { destacada no } \\
\text { texto }\end{array}$ & $\begin{array}{l}\text { Inferências a partir } \\
\text { de trechos das } \\
\text { narrativas que } \\
\text { correspondem a } \\
\text { concepções de } \\
\text { educação }\end{array}$ & Participantes & Ações & Método & $\begin{array}{l}\text { Objetivo(s) das } \\
\text { ações }\end{array}$ & $\begin{array}{l}\text { Mudanças } \\
\text { ocorridas }\end{array}$ \\
\hline $\begin{array}{l}\text { "Encontros e } \\
\text { movimentos: a } \\
\text { formação em } \\
\text { Educação } \\
\text { Permanente em } \\
\text { Saúde" }\end{array}$ & $\begin{array}{l}\text { Secretaria de } \\
\text { Gestão do } \\
\text { Trabalho e da } \\
\text { Educação na } \\
\text { Saúde do } \\
\text { Ministério da } \\
\text { Saúde }\end{array}$ & $\begin{array}{c}\text { Agosto de } \\
2014\end{array}$ & $\begin{array}{l}\text { [...] a prática da } \\
\text { EPS transcende a } \\
\text { formalidade, } \\
\text { podendo } \\
\text { acontecer nos } \\
\text { debates e } \\
\text { reflexões, nas } \\
\text { trocas de saberes } \\
\text { e experiências, nas } \\
\text { práticas de } \\
\text { cuidado e } \\
\text { acolhimento, nas } \\
\text { conversas de } \\
\text { corredor, nos } \\
\text { "cafezinhos", nos } \\
\text { processos de } \\
\text { aprendizagem, na } \\
\text { participação ativa } \\
\text { dos trabalhadores } \\
\text { nas ações e na } \\
\text { gestão de seu } \\
\text { setor. }\end{array}$ & $\begin{array}{l}\text { A EPS "... } \\
\text { transcende a } \\
\text { formalidade, } \\
\text { podendo } \\
\text { acontecer nos } \\
\text { debates e nas } \\
\text { reflexões, nas } \\
\text { trocas de saberes e } \\
\text { experiências, nas } \\
\text { práticas de } \\
\text { cuidado e } \\
\text { acolhimento, nas } \\
\text { conversas de } \\
\text { corredor, nos } \\
\text { "cafezinhos", nos } \\
\text { processos de } \\
\text { aprendizagem, na } \\
\text { participação ativa } \\
\text { dos trabalhadores } \\
\text { nas ações e na } \\
\text { gestão de seu } \\
\text { setor." }\end{array}$ & $\begin{array}{l}\text { Trabalhadores do } \\
\text { Departamento de } \\
\text { Gestão da } \\
\text { Educação na Saúde } \\
\text { (DEGES/SGTES/MS) }\end{array}$ & $\begin{array}{l}\text { Encontros entre os } \\
\text { trabalhadores }\end{array}$ & $\begin{array}{l}\text { Nos encontros, } \\
\text { são utilizadas } \\
\text { metodologias de } \\
\text { facilitação } \\
\text { associadas entre } \\
\text { um momento e } \\
\text { outro. }\end{array}$ & $\begin{array}{l}\text { Os encontros são } \\
\text { promovidos para } \\
\text { trocas com } \\
\text { profissionais da } \\
\text { Saúde Coletiva e } \\
\text { para a } \\
\text { continuidade dos } \\
\text { grupos de trabalho } \\
\text { para troca e } \\
\text { compartilhamento } \\
\text { de ideias, } \\
\text { pensamentos, } \\
\text { proposições e } \\
\text { afetos, } \\
\text { objetivando a } \\
\text { problematização } \\
\text { do cotidiano do } \\
\text { trabalho. }\end{array}$ & $\begin{array}{l}\text { Não foi possível } \\
\text { identificar as } \\
\text { mudanças } \\
\text { ocorridas a partir } \\
\text { da experiência } \\
\text { apresentada na } \\
\text { narrativa. }\end{array}$ \\
\hline
\end{tabular}




\begin{tabular}{|c|c|c|c|c|c|c|c|c|c|}
\hline Narrativas & Local & Início & $\begin{array}{l}\text { Concepção de } \\
\text { educação } \\
\text { destacada no } \\
\text { texto }\end{array}$ & $\begin{array}{l}\text { Inferências a partir } \\
\text { de trechos das } \\
\text { narrativas que } \\
\text { correspondem a } \\
\text { concepções de } \\
\text { educação }\end{array}$ & Participantes & Ações & Método & $\begin{array}{l}\text { Objetivo(s) das } \\
\text { ações }\end{array}$ & $\begin{array}{l}\text { Mudanças } \\
\text { ocorridas }\end{array}$ \\
\hline $\begin{array}{l}\text { "Encontros e } \\
\text { movimentos: a } \\
\text { educação } \\
\text { permanente em } \\
\text { cena" }\end{array}$ & $\begin{array}{l}\text { Secretaria de } \\
\text { Gestão do } \\
\text { Trabalho e da } \\
\text { Educação na } \\
\text { Saúde do } \\
\text { Ministério da } \\
\text { Saúde }\end{array}$ & $\begin{array}{l}\text { Agosto de } \\
2014\end{array}$ & $\begin{array}{l}{[. .] \text { a EPS }} \\
\text { transcende a } \\
\text { formalidade, } \\
\text { podendo } \\
\text { acontecer todos os } \\
\text { dias no trabalho, } \\
\text { nos debates e } \\
\text { reflexões, nas } \\
\text { trocas de saberes } \\
\text { e experiências, nas } \\
\text { práticas de } \\
\text { cuidado e } \\
\text { acolhimento, nas } \\
\text { conversas de } \\
\text { corredor, no } \\
\text { "cafezinho" e nos } \\
\text { processos de } \\
\text { aprendizagem, } \\
\text { bem como na } \\
\text { participação ativa } \\
\text { dos trabalhadores } \\
\text { nas ações e na } \\
\text { gestão de seu } \\
\text { setor. }\end{array}$ & \begin{tabular}{|l} 
A EPS "... \\
transcende a \\
formalidade, \\
podendo \\
acontecer todos os \\
dias no trabalho, \\
nos debates e nas \\
reflexões, nas \\
trocas de saberes e \\
experiências, nas \\
práticas de \\
cuidado e \\
acolhimento, nas \\
conversas de \\
corredor, nos \\
"cafezinhos", nos \\
processos de \\
aprendizagem, na \\
participação ativa \\
dos trabalhadores \\
nas ações e na \\
gestão de seu \\
setor."
\end{tabular} & \begin{tabular}{|l|} 
Trabalhadores do \\
Departamento de \\
Gestão da \\
Educação na Saúde \\
(DEGES/SGTES/MS)
\end{tabular} & $\begin{array}{l}\text { Encontros entre os } \\
\text { trabalhadores do } \\
\text { Departamento de } \\
\text { Gestão da } \\
\text { Educação na } \\
\text { Saúde. }\end{array}$ & $\begin{array}{l}\text { Nos encontros são } \\
\text { utilizadas } \\
\text { metodologias de } \\
\text { facilitação } \\
\text { associadas entre } \\
\text { um momento e } \\
\text { outro. Num dos } \\
\text { encontros foi } \\
\text { utilizada a } \\
\text { metodologia das } \\
\text { árvores com o } \\
\text { objetivo de } \\
\text { possibilitar a } \\
\text { correlação } \\
\text { metafórica entre } \\
\text { as ações } \\
\text { realizadas e as } \\
\text { principais partes } \\
\text { de uma planta } \\
\text { (raízes, tronco e } \\
\text { copa). }\end{array}$ & $\begin{array}{l}\text { Os encontros têm } \\
\text { como objetivo } \\
\text { trazer novos } \\
\text { olhares sobre o } \\
\text { trabalho, fomentar } \\
\text { novas reflexões, } \\
\text { dar continuidade } \\
\text { aos trabalhos em } \\
\text { grupo (modo de } \\
\text { organização do } \\
\text { departamento) } \\
\text { para a troca e } \\
\text { compartilhamento } \\
\text { de ideias, } \\
\text { pensamentos, } \\
\text { proposições e } \\
\text { afetos. }\end{array}$ & $\begin{array}{l}\text { Não foi possível } \\
\text { identificar as } \\
\text { mudanças } \\
\text { ocorridas a partir } \\
\text { da experiência } \\
\text { apresentada na } \\
\text { narrativa. }\end{array}$ \\
\hline
\end{tabular}




\begin{tabular}{|c|c|c|c|c|c|c|c|c|c|}
\hline Narrativas & Local & Início & $\begin{array}{l}\text { Concepção de } \\
\text { educação } \\
\text { destacada no } \\
\text { texto }\end{array}$ & $\begin{array}{l}\text { Inferências a partir } \\
\text { de trechos das } \\
\text { narrativas que } \\
\text { correspondem a } \\
\text { concepções de } \\
\text { educação }\end{array}$ & Participantes & Ações & Método & $\begin{array}{l}\text { Objetivo(s) das } \\
\text { ações }\end{array}$ & $\begin{array}{l}\text { Mudanças } \\
\text { ocorridas }\end{array}$ \\
\hline $\begin{array}{l}\text { "EpiSUS: uma } \\
\text { experiência bem- } \\
\text { sucedida no } \\
\text { atendimento às } \\
\text { emergências em } \\
\text { saúde pública" }\end{array}$ & $\begin{array}{l}\text { Secretaria de } \\
\text { Vigilância em } \\
\text { Saúde do } \\
\text { Ministério da } \\
\text { Saúde }\end{array}$ & $\begin{array}{c}\text { Não foi } \\
\text { mencionado. }\end{array}$ & $\begin{array}{l}\text { NÃO DECLARADA } \\
\text { EXPRESSAMENTE }\end{array}$ & \begin{tabular}{|l} 
Destaca \\
expressões \\
correlacionadas à \\
Educação \\
Permanente em \\
Saúde como \\
"aprender \\
fazendo".
\end{tabular} & $\begin{array}{l}\text { Profissionais de } \\
\text { saúde que atuam } \\
\text { na Vigilância em } \\
\text { Saúde. }\end{array}$ & $\begin{array}{l}\text { Estratégias de } \\
\text { aprendizagem em } \\
\text { serviço. }\end{array}$ & $\begin{array}{l}\text { Na narrativa, é } \\
\text { destacada a } \\
\text { metodologia do } \\
\text { "aprender } \\
\text { fazendo". É } \\
\text { desenvolvido } \\
\text { durante dois anos, } \\
\text { em que os } \\
\text { participantes } \\
\text { desenvolvem suas } \\
\text { atividades nas } \\
\text { diferentes áreas } \\
\text { técnicas que } \\
\text { compõem a } \\
\text { Secretaria de } \\
\text { Vigilância em } \\
\text { Saúde e são } \\
\text { deslocados para } \\
\text { as atividades de } \\
\text { investigações de } \\
\text { campo sempre } \\
\text { que ocorre uma } \\
\text { emergência em } \\
\text { saúde pública, em } \\
\text { qualquer parte do } \\
\text { País, ou quando } \\
\text { solicitado até em } \\
\text { âmbito } \\
\text { internacional. }\end{array}$ & $\begin{array}{l}\text { Aprimorar a } \\
\text { capacidade técnica } \\
\text { de profissionais de } \\
\text { saúde por meio de } \\
\text { ações de } \\
\text { aprendizagem em } \\
\text { serviço para atuar } \\
\text { na Vigilância em } \\
\text { Saúde, } \\
\text { prioritariamente } \\
\text { nas emergências } \\
\text { em saúde pública, } \\
\text { no âmbito do SUS. }\end{array}$ & $\begin{array}{l}\text { Apresenta como } \\
\text { visão de futuro ser } \\
\text { um programa de } \\
\text { educação em } \\
\text { Epidemiologia de } \\
\text { campo de } \\
\text { excelência, em } \\
\text { âmbito nacional e } \\
\text { internacional. }\end{array}$ \\
\hline
\end{tabular}




\begin{tabular}{|c|c|c|c|c|c|c|c|c|c|}
\hline Narrativas & Local & Início & $\begin{array}{l}\text { Concepção de } \\
\text { educação } \\
\text { destacada no } \\
\text { texto }\end{array}$ & $\begin{array}{l}\text { Inferências a partir } \\
\text { de trechos das } \\
\text { narrativas que } \\
\text { correspondem a } \\
\text { concepções de } \\
\text { educação }\end{array}$ & Participantes & Ações & Método & $\begin{array}{l}\text { Objetivo(s) das } \\
\text { ações }\end{array}$ & $\begin{array}{l}\text { Mudanças } \\
\text { ocorridas }\end{array}$ \\
\hline $\begin{array}{l}\text { "Excelência da } \\
\text { gestão pública: o } \\
\text { caso DATASUS/PB" }\end{array}$ & $\begin{array}{l}\text { Núcleo } \\
\text { Estadual do } \\
\text { Ministério da } \\
\text { Saúde na } \\
\text { Paraíba }\end{array}$ & 2012 & $\begin{array}{l}\text { NÃO DECLARADA } \\
\text { EXPRESSAMENTE }\end{array}$ & $\begin{array}{l}\text { Destaca uma ação } \\
\text { de reflexão sobre a } \\
\text { prática. }\end{array}$ & $\begin{array}{l}\text { Técnicos e } \\
\text { gestores do } \\
\text { DATASUS/PB. }\end{array}$ & $\begin{array}{l}\text { Oficinas de } \\
\text { autoavaliação da } \\
\text { gestão pública. }\end{array}$ & $\begin{array}{l}\text { Nas Oficinas é } \\
\text { utilizado o } \\
\text { Instrumento de } \\
\text { Avaliação da } \\
\text { Gestão Pública } \\
\text { (lagp) e a } \\
\text { elaboração do } \\
\text { Plano de Melhoria } \\
\text { da Gestão, } \\
\text { ferramentas do } \\
\text { Programa } \\
\text { Nacional da } \\
\text { Gestão Pública e } \\
\text { Desburocratização } \\
\text { (Gespública), } \\
\text { durante três dias } \\
\text { de imersão total. }\end{array}$ & Avaliar a gestão. & $\begin{array}{l}\text { A ação permitiu } \\
\text { uma análise } \\
\text { conjunta das } \\
\text { práticas } \\
\text { desenvolvidas e a } \\
\text { identificação de } \\
\text { resultados, dos } \\
\text { critérios } \\
\text { específicos de } \\
\text { liderança, } \\
\text { estratégias, } \\
\text { planos, cidadãos, } \\
\text { sociedade, } \\
\text { informação, } \\
\text { conhecimento, } \\
\text { pessoas, } \\
\text { processos e } \\
\text { resultados, } \\
\text { oportunizando o } \\
\text { diálogo, a } \\
\text { discussão e o } \\
\text { consenso da } \\
\text { equipe envolvida, } \\
\text { além do exercício } \\
\text { do planejamento } \\
\text { e da elaboração } \\
\text { do relatório de } \\
\text { gestão. }\end{array}$ \\
\hline
\end{tabular}




\begin{tabular}{|c|c|c|c|c|c|c|c|c|c|}
\hline Narrativas & Local & Início & $\begin{array}{l}\text { Concepção de } \\
\text { educação } \\
\text { destacada no } \\
\text { texto }\end{array}$ & $\begin{array}{l}\text { Inferências a partir } \\
\text { de trechos das } \\
\text { narrativas que } \\
\text { correspondem a } \\
\text { concepções de } \\
\text { educação }\end{array}$ & Participantes & Ações & Método & $\begin{array}{l}\text { Objetivo(s) das } \\
\text { ações }\end{array}$ & $\begin{array}{l}\text { Mudanças } \\
\text { ocorridas }\end{array}$ \\
\hline $\begin{array}{l}\text { "Experiências } \\
\text { vivenciadas pelas } \\
\text { equipes } \\
\text { multiprofissionais } \\
\text { de saúde indígena } \\
\text { durante as } \\
\text { macroações em } \\
\text { área indígena" }\end{array}$ & $\begin{array}{l}\text { Secretaria } \\
\text { Especial de } \\
\text { Saúde Indígena } \\
\text { do Ministério } \\
\text { da Saúde }\end{array}$ & Abril de 2014 & $\begin{array}{l}\text { "A Educação } \\
\text { Permanente em } \\
\text { Saúde se faz no dia } \\
\text { a dia, na troca de } \\
\text { experiência e na } \\
\text { participação." }\end{array}$ & \begin{tabular}{|l} 
"A Educação \\
Permanente faz-se \\
no dia a dia, na \\
troca de \\
experiência e na \\
participação."
\end{tabular} & \begin{tabular}{|l|} 
Equipes \\
multiprofissionais \\
de saúde indígena
\end{tabular} & $\begin{array}{l}\text { Roda de conversa, } \\
\text { jogos educativos e } \\
\text { palestras }\end{array}$ & $\begin{array}{l}\text { Não se percebe o } \\
\text { método na } \\
\text { narrativa. }\end{array}$ & $\begin{array}{l}\text { Envolver os } \\
\text { indígenas nas } \\
\text { ações educativas } \\
\text { propostas e } \\
\text { desenvolvidas na } \\
\text { CASAI-Maués. }\end{array}$ & $\begin{array}{l}\text { Segundo a } \\
\text { narrativa, "... o } \\
\text { envolvimento e a } \\
\text { participação, } \\
\text { tanto pela equipe } \\
\text { como pelos } \\
\text { indígenas, foram } \\
\text { satisfatórios." }\end{array}$ \\
\hline $\begin{array}{l}\text { "Formação em } \\
\text { Educação } \\
\text { Permanente em } \\
\text { Saúde: grupo de } \\
\text { trabalho 3" }\end{array}$ & $\begin{array}{l}\text { Secretaria de } \\
\text { Gestão do } \\
\text { Trabalho e da } \\
\text { Educação na } \\
\text { Saúde do } \\
\text { Ministério da } \\
\text { Saúde }\end{array}$ & 2014 & $\begin{array}{l}\text { Embora a EPS não } \\
\text { aconteça apenas } \\
\text { em espaços } \\
\text { institucionalizados, } \\
\text { percebe-se a } \\
\text { necessidade de se } \\
\text { pensar, criar e } \\
\text { proporcionar } \\
\text { espaços de } \\
\text { reflexões sobre a } \\
\text { "prática de ensino- } \\
\text { aprendizagem". }\end{array}$ & $\begin{array}{l}\text { "Embora a EPS não } \\
\text { aconteça apenas } \\
\text { em espaços } \\
\text { institucionalizados, } \\
\text { percebe-se a } \\
\text { necessidade de se } \\
\text { pensar, criar e } \\
\text { proporcionar } \\
\text { espaços de } \\
\text { reflexões sobre a } \\
\text { 'prática de ensino- } \\
\text { aprendizagem'." }\end{array}$ & \begin{tabular}{|l|} 
Trabalhadores do \\
Departamento de \\
Gestão da \\
Educação na Saúde \\
(DEGES/SGTES/MS) \\
\end{tabular} & \begin{tabular}{|l} 
Elaboração de \\
materiais \\
informativos; \\
construção de \\
estratégias que \\
favoreçam a \\
integração dos \\
trabalhadores do \\
departamento; \\
organização de \\
material sobre a \\
formação de \\
apoiadores do \\
departamento; e \\
construção de \\
projeto de \\
formação em EPS \\
nas redes \\
prioritárias.
\end{tabular} & \begin{tabular}{|l|} 
São realizados \\
encontros entre \\
os trabalhadores \\
do Departamento \\
de Gestão da \\
Educação na \\
Saúde.
\end{tabular} & $\begin{array}{l}\text { Elaborar propostas } \\
\text { de formação em } \\
\text { saúde que } \\
\text { fortaleçam a } \\
\text { Política Nacional } \\
\text { de Educação } \\
\text { Permanente, tanto } \\
\text { no âmbito interno } \\
\text { quanto externo ao } \\
\text { DEGES, as quais } \\
\text { estejam ancoradas } \\
\text { em mudanças do } \\
\text { fazer no cotidiano } \\
\text { do trabalho que } \\
\text { possibilitem } \\
\text { melhorias nos } \\
\text { serviços de saúde. }\end{array}$ & $\begin{array}{l}\text { Não foi possível } \\
\text { identificar as } \\
\text { mudanças } \\
\text { ocorridas a partir } \\
\text { da experiência } \\
\text { apresentada na } \\
\text { narrativa. }\end{array}$ \\
\hline $\begin{array}{l}\text { "Gerenciamento } \\
\text { das filas cirúrgicas } \\
\text { em um dos }\end{array}$ & $\begin{array}{l}\text { Hospital } \\
\text { Federal de } \\
\text { Bonsucesso - }\end{array}$ & $\begin{array}{c}\text { Não foi } \\
\text { mencionado. }\end{array}$ & $\begin{array}{l}\text { “A Educação } \\
\text { Permanente é o } \\
\text { campo de }\end{array}$ & $\begin{array}{l}\text { Destaca trechos de } \\
\text { falas ocorridas } \\
\text { durante a I Mostra }\end{array}$ & \begin{tabular}{|l|} 
Trabalhadores do \\
Hospital Federal de \\
Bonsucesso.
\end{tabular} & Rodas de conversa & $\begin{array}{l}\text { Valorização e } \\
\text { utilização das } \\
\text { experiências dos }\end{array}$ & $\begin{array}{l}\text { Apresentar um } \\
\text { plano de ação para } \\
\text { organizar e realizar }\end{array}$ & $\begin{array}{l}\text { A ação } \\
\text { possibilitou as } \\
\text { mudanças e a }\end{array}$ \\
\hline
\end{tabular}




\begin{tabular}{|c|c|c|c|c|c|c|c|c|c|}
\hline Narrativas & Local & Início & $\begin{array}{l}\text { Concepção de } \\
\text { educação } \\
\text { destacada no } \\
\text { texto }\end{array}$ & $\begin{array}{l}\text { Inferências a partir } \\
\text { de trechos das } \\
\text { narrativas que } \\
\text { correspondem a } \\
\text { concepções de } \\
\text { educação }\end{array}$ & Participantes & Ações & Método & $\begin{array}{l}\text { Objetivo(s) das } \\
\text { ações }\end{array}$ & $\begin{array}{l}\text { Mudanças } \\
\text { ocorridas }\end{array}$ \\
\hline $\begin{array}{l}\text { hospitais federais } \\
\text { localizado no Rio } \\
\text { de Janeiro: relato } \\
\text { de experiência" }\end{array}$ & Rio de Janeiro & & $\begin{array}{l}\text { produção de } \\
\text { conhecimentos } \\
\text { que são adquiridos } \\
\text { no mundo do } \\
\text { trabalho, que cada } \\
\text { um tem a sua } \\
\text { visão distinta, que } \\
\text { cada um tem uma } \\
\text { academia dentro } \\
\text { de si mesmo e que } \\
\text { na maior parte das } \\
\text { vezes a gente } \\
\text { tende a comprar } \\
\text { os saberes de } \\
\text { outras academias } \\
\text { [...]" }\end{array}$ & $\begin{array}{l}\text { Nacional de } \\
\text { Educação } \\
\text { Permanente com a } \\
\text { concepção de EP. }\end{array}$ & & & $\begin{array}{l}\text { profissionais como } \\
\text { potencial criativo. }\end{array}$ & $\begin{array}{l}\text { cirurgias dos } \\
\text { pacientes inscritos } \\
\text { nas filas, conforme } \\
\text { prazos e } \\
\text { formalidade } \\
\text { descritos na ação } \\
\text { judicial } \\
\text { apresentada à } \\
\text { União, ao Estado e } \\
\text { ao Município do } \\
\text { Rio de Janeiro. }\end{array}$ & $\begin{array}{l}\text { transformação } \\
\text { nas práticas } \\
\text { profissionais dos } \\
\text { trabalhadores do } \\
\text { Hospital Federal } \\
\text { de Bonsucesso. }\end{array}$ \\
\hline
\end{tabular}




\begin{tabular}{|c|c|c|c|c|c|c|c|c|c|}
\hline Narrativas & Local & Início & $\begin{array}{l}\text { Concepção de } \\
\text { educação } \\
\text { destacada no } \\
\text { texto }\end{array}$ & $\begin{array}{l}\text { Inferências a partir } \\
\text { de trechos das } \\
\text { narrativas que } \\
\text { correspondem a } \\
\text { concepções de } \\
\text { educação }\end{array}$ & Participantes & Ações & Método & $\begin{array}{l}\text { Objetivo(s) das } \\
\text { ações }\end{array}$ & $\begin{array}{l}\text { Mudanças } \\
\text { ocorridas }\end{array}$ \\
\hline & & & & \begin{tabular}{|l} 
olhar sensível \\
sobre esses \\
cenários e seus \\
atores, e \\
vislumbrar novas \\
possibilidades de \\
educador agora é \\
um facilitador da \\
produção de novos \\
conhecimentos, de \\
cuidado centrado \\
no indivíduo capaz \\
de modificar sua \\
realidade.
\end{tabular} & & & & & $\begin{array}{l}\text { educação } \\
\text { continuada; } \\
\text { evidente melhora } \\
\text { na apropriação } \\
\text { dos conceitos } \\
\text { teóricos e das } \\
\text { ações práticas; } \\
\text { reformulação de } \\
\text { ações da prática a } \\
\text { partir dos erros } \\
\text { identificados } \\
\text { pelos próprios } \\
\text { envolvidos; } \\
\text { desenvolvimento } \\
\text { de novo olhar dos } \\
\text { trabalhadores } \\
\text { sobre seus } \\
\text { próprios cenários } \\
\text { de prática. }\end{array}$ \\
\hline
\end{tabular}




\begin{tabular}{|c|c|c|c|c|c|c|c|c|c|}
\hline Narrativas & Local & Início & $\begin{array}{l}\text { Concepção de } \\
\text { educação } \\
\text { destacada no } \\
\text { texto }\end{array}$ & $\begin{array}{l}\text { Inferências a partir } \\
\text { de trechos das } \\
\text { narrativas que } \\
\text { correspondem a } \\
\text { concepções de } \\
\text { educação }\end{array}$ & Participantes & Ações & Método & $\begin{array}{l}\text { Objetivo(s) das } \\
\text { ações }\end{array}$ & $\begin{array}{c}\text { Mudanças } \\
\text { ocorridas }\end{array}$ \\
\hline $\begin{array}{l}\text { "I Capacitação em } \\
\text { atuação } \\
\text { multidisciplinar na } \\
\text { assistência } \\
\text { farmacêutica do } \\
\text { DSEI Potiguara" }\end{array}$ & $\begin{array}{l}\text { Secretaria } \\
\text { Especial de } \\
\text { Saúde Indígena } \\
\text { do Ministério } \\
\text { da Saúde }\end{array}$ & $\begin{array}{l}\text { Setembro de } \\
2014\end{array}$ & $\begin{array}{l}\text { NÃO DECLARADA } \\
\text { EXPRESSAMENTE }\end{array}$ & \begin{tabular}{|l} 
Trocar \\
conhecimentos no \\
dia a dia, \\
contribuindo tanto \\
com os aspectos \\
técnicos quanto \\
com os \\
motivacionais, o \\
que ao final, por \\
consequência, \\
também \\
influenciará no \\
serviço prestado.
\end{tabular} & $\begin{array}{l}\text { Profissionais que } \\
\text { atuam nas equipes } \\
\text { de saúde. }\end{array}$ & \begin{tabular}{|l} 
Capacitação em \\
atuação \\
multidisciplinar na \\
assistência \\
farmacêutica.
\end{tabular} & \begin{tabular}{|l} 
A capacitação foi \\
idealizada tendo \\
como \\
instrumentos \\
motivadores e \\
norteadores, \\
entre outros, a \\
Política Nacional \\
da Assistência \\
Farmacêutica e a \\
Política Nacional \\
de Medicamentos. \\
Foi utilizada como \\
estratégia e \\
metodologia uma \\
abordagem em \\
conformidade \\
com os objetivos, \\
atribuições, \\
princípios e \\
diretrizes do sus, \\
assim como o \\
Subsistema de \\
Atenção à Saúde \\
Indígena e a \\
utilização de \\
conteúdos \\
relacionados com \\
problemas reais \\
da equipe de \\
saúde. Foram
\end{tabular} & \begin{tabular}{|l} 
Debater, \\
compartilhar, e \\
orientar os \\
profissionais que \\
atuam nas equipes \\
de saúde, sobre as \\
atividades \\
relacionadas à \\
assistência \\
farmacêutica, com \\
o propósito final \\
de melhorar as \\
ações de saúde, \\
ampliar o acesso \\
da população \\
indígena aos \\
medicamentos \\
essenciais e \\
promover seu uso \\
racional.
\end{tabular} & $\begin{array}{l}\text { Buscou-se } \\
\text { orientar e } \\
\text { habilitar os } \\
\text { profissionais } \\
\text { envolvidos, direta } \\
\text { ou indiretamente, } \\
\text { com a assistência } \\
\text { farmacêutica para } \\
\text { que, em suas } \\
\text { atividades, } \\
\text { venham a realizar } \\
\text { ações que } \\
\text { melhorem a } \\
\text { atenção à saúde } \\
\text { prestada pelo } \\
\text { DSEl e que, } \\
\text { utilizando os } \\
\text { conhecimentos } \\
\text { adquiridos, atuem } \\
\text { cotidianamente } \\
\text { como } \\
\text { multiplicadores } \\
\text { para os demais } \\
\text { trabalhadores. }\end{array}$ \\
\hline
\end{tabular}




\begin{tabular}{|c|c|c|c|c|c|c|c|c|c|}
\hline Narrativas & Local & Início & $\begin{array}{l}\text { Concepção de } \\
\text { educação } \\
\text { destacada no } \\
\text { texto }\end{array}$ & $\begin{array}{l}\text { Inferências a partir } \\
\text { de trechos das } \\
\text { narrativas que } \\
\text { correspondem a } \\
\text { concepções de } \\
\text { educação }\end{array}$ & Participantes & Ações & Método & $\begin{array}{l}\text { Objetivo(s) das } \\
\text { ações }\end{array}$ & $\begin{array}{c}\text { Mudanças } \\
\text { ocorridas }\end{array}$ \\
\hline & & & & & & & $\begin{array}{l}\text { apresentados e } \\
\text { discutidos temas } \\
\text { como a } \\
\text { farmacologia dos } \\
\text { medicamentos } \\
\text { padronizados pela } \\
\text { instituição, o ciclo } \\
\text { da assistência } \\
\text { farmacêutica } \\
\text { (seleção, } \\
\text { programação, } \\
\text { aquisição, } \\
\text { armazenamento, } \\
\text { distribuição e } \\
\text { dispensação de } \\
\text { medicamentos), o } \\
\text { uso racional de } \\
\text { medicamentos, } \\
\text { Rename (Relação } \\
\text { Nacional de } \\
\text { Medicamentos } \\
\text { Essenciais), entre } \\
\text { outros. }\end{array}$ & & \\
\hline
\end{tabular}




\begin{tabular}{|c|c|c|c|c|c|c|c|c|c|}
\hline Narrativas & Local & Início & $\begin{array}{l}\text { Concepção de } \\
\text { educação } \\
\text { destacada no } \\
\text { texto }\end{array}$ & $\begin{array}{l}\text { Inferências a partir } \\
\text { de trechos das } \\
\text { narrativas que } \\
\text { correspondem a } \\
\text { concepções de } \\
\text { educação }\end{array}$ & Participantes & Ações & Método & $\begin{array}{l}\text { Objetivo(s) das } \\
\text { ações }\end{array}$ & $\begin{array}{l}\text { Mudanças } \\
\text { ocorridas }\end{array}$ \\
\hline $\begin{array}{l}\text { "I Semana de } \\
\text { promoção à saúde } \\
\text { e segurança do } \\
\text { trabalhador de } \\
\text { Enfermagem: } \\
\text { integração de } \\
\text { serviços do } \\
\text { Hospital Federal do } \\
\text { Andaraí para a } \\
\text { qualidade de vida } \\
\text { no trabalho" }\end{array}$ & $\begin{array}{l}\text { Hospital } \\
\text { Federal do } \\
\text { Andaraí - Rio } \\
\text { de Janeiro }\end{array}$ & $\begin{array}{c}\text { Não foi } \\
\text { mencionado. }\end{array}$ & $\begin{array}{l}\text { [...] é um processo } \\
\text { permanente, que } \\
\text { busca alternativas } \\
\text { e soluções para os } \\
\text { problemas de } \\
\text { saúde reais } \\
\text { vivenciados pelas } \\
\text { pessoas e grupos } \\
\text { em suas } \\
\text { realidades. Ela } \\
\text { deve ser } \\
\text { entendida como } \\
\text { um fator que } \\
\text { influenciará no } \\
\text { processo de } \\
\text { reflexão e } \\
\text { transformação das } \\
\text { práticas vigentes } \\
\text { nos serviços, onde } \\
\text { profissionais de } \\
\text { diferentes } \\
\text { especialidades } \\
\text { podem se integrar } \\
\text { e enfrentar a } \\
\text { realidade, pela } \\
\text { complementação } \\
\text { e/ou aquisição de } \\
\text { novos } \\
\text { conhecimentos. }\end{array}$ & $\begin{array}{l}\text { Processo } \\
\text { permanente que } \\
\text { busca alternativas } \\
\text { e soluções para os } \\
\text { problemas de } \\
\text { saúde reais } \\
\text { vivenciados pelas } \\
\text { pessoas e pelos } \\
\text { grupos em suas } \\
\text { realidades. A EP } \\
\text { deve ser entendida } \\
\text { como um fator que } \\
\text { influenciará no } \\
\text { processo de } \\
\text { reflexão e } \\
\text { transformação das } \\
\text { práticas vigentes } \\
\text { nos serviços, onde } \\
\text { profissionais de } \\
\text { diferentes } \\
\text { especialidades } \\
\text { podem se integrar } \\
\text { e enfrentar a } \\
\text { realidade, pela } \\
\text { complementação } \\
\text { e/ou aquisição de } \\
\text { novos } \\
\text { conhecimentos. }\end{array}$ & \begin{tabular}{|l|} 
Trabalhadores de \\
enfermagem do \\
Hospital Federal do \\
Andaraí
\end{tabular} & $\begin{array}{l}\text { I Semana de } \\
\text { promoção à saúde } \\
\text { e segurança do } \\
\text { trabalhador de } \\
\text { enfermagem do } \\
\text { HFA. }\end{array}$ & $\begin{array}{l}\text { Constituíram-se } \\
\text { três mesas } \\
\text { redondas, nas } \\
\text { quais foram } \\
\text { discutidos temas } \\
\text { relacionados à } \\
\text { saúde do } \\
\text { indivíduo e do } \\
\text { trabalhador. }\end{array}$ & $\begin{array}{l}\text { Integração de } \\
\text { serviços do } \\
\text { Hospital Federal } \\
\text { do Andaraí para a } \\
\text { qualidade de vida } \\
\text { no trabalho. }\end{array}$ & $\begin{array}{l}\text { Integração } \\
\text { multiprofissional, } \\
\text { desenvolvimento } \\
\text { de atividade física, } \\
\text { criação de } \\
\text { parcerias, } \\
\text { (estreitando laços } \\
\text { entre os } \\
\text { profissionais) e a } \\
\text { orientação dos } \\
\text { trabalhadores de } \\
\text { Enfermagem } \\
\text { sobre a } \\
\text { importância da } \\
\text { conservação e da } \\
\text { proteção de sua } \\
\text { saúde, com } \\
\text { trabalho voltado } \\
\text { para a } \\
\text { sensibilização } \\
\text { sobre qualidade } \\
\text { de vida, } \\
\text { prevenção de } \\
\text { doenças e de } \\
\text { acidentes no } \\
\text { ambiente de } \\
\text { trabalho, sob } \\
\text { diferentes óticas. }\end{array}$ \\
\hline
\end{tabular}




\begin{tabular}{|c|c|c|c|c|c|c|c|c|c|}
\hline Narrativas & Local & Início & $\begin{array}{l}\text { Concepção de } \\
\text { educação } \\
\text { destacada no } \\
\text { texto }\end{array}$ & $\begin{array}{l}\text { Inferências a partir } \\
\text { de trechos das } \\
\text { narrativas que } \\
\text { correspondem a } \\
\text { concepções de } \\
\text { educação }\end{array}$ & Participantes & Ações & Método & $\begin{array}{l}\text { Objetivo(s) das } \\
\text { ações }\end{array}$ & $\begin{array}{l}\text { Mudanças } \\
\text { ocorridas }\end{array}$ \\
\hline $\begin{array}{l}\text { "O design } \\
\text { educacional na } \\
\text { capacitação de } \\
\text { procedimentos de } \\
\text { protocolo e } \\
\text { operacionalização } \\
\text { do SIPAR" }\end{array}$ & $\begin{array}{l}\text { Núcleo } \\
\text { Estadual do } \\
\text { Ministério da } \\
\text { Saúde em São } \\
\text { Paulo }\end{array}$ & $\begin{array}{c}\text { Não foi } \\
\text { mencionado. }\end{array}$ & $\begin{array}{l}\text { "Para capacitar, ou } \\
\text { simplesmente } \\
\text { melhorar nossa } \\
\text { rotina de trabalho, } \\
\text { basta envolver a } \\
\text { equipe, tirando } \\
\text { dela mesma as } \\
\text { melhores ideias, } \\
\text { construindo assim } \\
\text { uma rede positiva, } \\
\text { na qual todos } \\
\text { possam fazer, de } \\
\text { modo simples, o } \\
\text { que já fazem." }\end{array}$ & $\begin{array}{l}\text { "Para capacitar, ou } \\
\text { simplesmente } \\
\text { melhorar nossa } \\
\text { rotina de trabalho, } \\
\text { basta envolver a } \\
\text { equipe, tirando } \\
\text { dela as melhores } \\
\text { ideias, construindo } \\
\text { assim uma rede } \\
\text { positiva, na qual } \\
\text { todos possam } \\
\text { fazer, de modo } \\
\text { simples, o que já } \\
\text { fazem." }\end{array}$ & $\begin{array}{l}\text { Não fica claro na } \\
\text { narrativa, quem } \\
\text { são os } \\
\text { participantes da } \\
\text { ação desenvolvida. }\end{array}$ & $\begin{array}{l}\text { Capacitação sobre } \\
\text { o SIPAR (Sistema } \\
\text { Integrado de } \\
\text { Protocolo e } \\
\text { Arquivo) }\end{array}$ & $\begin{array}{l}\text { Não foi } \\
\text { apresentado o } \\
\text { método utilizado. }\end{array}$ & $\begin{array}{l}\text { Não se percebe os } \\
\text { objetivos das } \\
\text { ações na narrativa. }\end{array}$ & $\begin{array}{l}\text { Não foi possível } \\
\text { identificar as } \\
\text { mudanças } \\
\text { ocorridas a partir } \\
\text { da experiência } \\
\text { apresentada na } \\
\text { narrativa. }\end{array}$ \\
\hline $\begin{array}{l}\text { "O Distrito } \\
\text { Sanitário Especial } \\
\text { Indígena } \\
\text { Yanomami: } \\
\text { aprendendo a } \\
\text { fortalecer a } \\
\text { participação social" }\end{array}$ & $\begin{array}{l}\text { Secretaria } \\
\text { Especial de } \\
\text { Saúde Indígena } \\
\text { do Ministério } \\
\text { da Saúde }\end{array}$ & $\begin{array}{c}\text { Não foi } \\
\text { mencionado. }\end{array}$ & $\begin{array}{l}{[. .] \text { movimentos }} \\
\text { de educação em } \\
\text { saúde numa } \\
\text { perspectiva } \\
\text { dialógica, } \\
\text { emancipadora, } \\
\text { participativa, } \\
\text { criativa e que } \\
\text { contribuísse para a } \\
\text { autonomia do } \\
\text { usuário, no que diz } \\
\text { respeito à sua } \\
\text { condição de } \\
\text { sujeito de direito e } \\
\text { autor de sua } \\
\text { trajetória de saúde }\end{array}$ & \begin{tabular}{|l|} 
Destaca aspectos \\
correlacionados ao \\
conceito de \\
Educação \\
Permanente em \\
Saúde.
\end{tabular} & $\begin{array}{l}\text { Profissionais e } \\
\text { conselheiros de } \\
\text { saúde. }\end{array}$ & $\begin{array}{l}\text { Rodas de conversa } \\
\text { com os } \\
\text { profissionais e } \\
\text { conselheiros de } \\
\text { saúde, além de } \\
\text { oficinas com os } \\
\text { palestrantes, } \\
\text { tradutores e } \\
\text { assessores. }\end{array}$ & \begin{tabular}{|l|} 
Partiu-se de uma \\
análise situacional \\
e foram \\
pontuados os nós \\
críticos, entre \\
eles: a instituição \\
e os conselheiros \\
de saúde não \\
tinham \\
experiência em \\
realizar um evento \\
dessa natureza; \\
não tinham os \\
palestrantes, e os \\
tradutores e \\
assessores do
\end{tabular} & \begin{tabular}{|l} 
Fortalecer a \\
participação social \\
por meio das \\
conferências e que \\
estas se \\
constituíssem em \\
movimentos de \\
educação em \\
saúde numa \\
perspectiva \\
dialógica, \\
emancipadora, \\
participativa, \\
criativa e que, \\
ainda, \\
contribuíssem para
\end{tabular} & \begin{tabular}{|l} 
Todos os nós \\
críticos \\
apresentados no \\
método foram \\
superados.
\end{tabular} \\
\hline
\end{tabular}




\begin{tabular}{|c|c|c|c|c|c|c|c|c|c|}
\hline Narrativas & Local & Início & $\begin{array}{l}\text { Concepção de } \\
\text { educação } \\
\text { destacada no } \\
\text { texto }\end{array}$ & $\begin{array}{l}\text { Inferências a partir } \\
\text { de trechos das } \\
\text { narrativas que } \\
\text { correspondem a } \\
\text { concepções de } \\
\text { educação }\end{array}$ & Participantes & Ações & Método & $\begin{array}{l}\text { Objetivo(s) das } \\
\text { ações }\end{array}$ & $\begin{array}{l}\text { Mudanças } \\
\text { ocorridas }\end{array}$ \\
\hline & & & $\begin{array}{l}\text { e doença; como } \\
\text { também a } \\
\text { autonomia dos } \\
\text { profissionais } \\
\text { diante da } \\
\text { possibilidade de } \\
\text { reinventar modos } \\
\text { de cuidados mais } \\
\text { humanizados, } \\
\text { compartilhados e } \\
\text { integrais." }\end{array}$ & & & & $\begin{array}{l}\text { Distrito Sanitário } \\
\text { Especial Indígena } \\
\text { Yanomami tinham } \\
\text { dificuldades em } \\
\text { entender alguns } \\
\text { conceitos } \\
\text { trabalhados pelo } \\
\text { SUS e não tinham } \\
\text { conhecimento } \\
\text { sobre a Política } \\
\text { Nacional de Saúde } \\
\text { Indígena. }\end{array}$ & $\begin{array}{l}\text { a autonomia do } \\
\text { usuário, no que diz } \\
\text { respeito à sua } \\
\text { condição de } \\
\text { sujeito de direito e } \\
\text { autor de sua } \\
\text { trajetória de saúde } \\
\text { e doença; como } \\
\text { também a } \\
\text { autonomia dos } \\
\text { profissionais } \\
\text { diante da } \\
\text { possibilidade de } \\
\text { reinventar modos } \\
\text { de cuidados mais } \\
\text { humanizados, } \\
\text { compartilhados e } \\
\text { integrais. }\end{array}$ & \\
\hline $\begin{array}{l}\text { "Oficina de } \\
\text { preenchimento das } \\
\text { fichas } \\
\text { odontológicas e } \\
\text { estruturação do } \\
\text { processo de } \\
\text { informação dos } \\
\text { dados de saúde } \\
\text { bucal indígena do } \\
\text { DSEl Amapá e } \\
\text { Norte do Pará" }\end{array}$ & $\begin{array}{l}\text { Secretaria } \\
\text { Especial de } \\
\text { Saúde Indígena } \\
\text { do Ministério } \\
\text { da Saúde }\end{array}$ & $\begin{array}{c}\text { Não foi } \\
\text { mencionado. }\end{array}$ & $\begin{array}{l}{[\ldots . .] \text { o ambiente de }} \\
\text { trabalho nos leva à } \\
\text { busca de novos } \\
\text { conhecimentos } \\
\text { para que } \\
\text { possamos } \\
\text { implementar } \\
\text { novas estratégias e } \\
\text { melhorar o nosso } \\
\text { processo de } \\
\text { trabalho com o } \\
\text { público-alvo, de }\end{array}$ & \begin{tabular}{|l} 
"... o ambiente de \\
trabalho nos leva à \\
busca de novos \\
conhecimentos \\
para que \\
possamos \\
implementar \\
novas estratégias e \\
melhorar o nosso \\
processo de \\
trabalho."
\end{tabular} & $\begin{array}{l}\text { Não fica claro na } \\
\text { narrativa, quem } \\
\text { são os } \\
\text { participantes da } \\
\text { ação desenvolvida. }\end{array}$ & $\begin{array}{l}\text { Qualificação e } \\
\text { estruturação do } \\
\text { processo e da } \\
\text { informação da } \\
\text { produção das } \\
\text { ações realizadas na } \\
\text { ponta no que diz } \\
\text { respeito à saúde } \\
\text { bucal indígena do } \\
\text { DSEl Amapá e } \\
\text { Norte do Pará. }\end{array}$ & $\begin{array}{l}\text { Não foi } \\
\text { apresentado o } \\
\text { método utilizado. }\end{array}$ & $\begin{array}{l}\text { Estruturação do } \\
\text { processo de } \\
\text { informação dos } \\
\text { dados de saúde } \\
\text { bucal indígena do } \\
\text { DSEl Amapá e } \\
\text { Norte do Pará. }\end{array}$ & $\begin{array}{l}\text { "... melhoramos a } \\
\text { qualidade dos } \\
\text { dados informados } \\
\text { ao sistema de } \\
\text { informação da } \\
\text { atenção à saúde } \\
\text { indígena e, ..., } \\
\text { atingimos metas, } \\
\text { evitando perdas } \\
\text { de dados." }\end{array}$ \\
\hline
\end{tabular}




\begin{tabular}{|c|c|c|c|c|c|c|c|c|c|}
\hline Narrativas & Local & Início & $\begin{array}{l}\text { Concepção de } \\
\text { educação } \\
\text { destacada no } \\
\text { texto }\end{array}$ & $\begin{array}{l}\text { Inferências a partir } \\
\text { de trechos das } \\
\text { narrativas que } \\
\text { correspondem a } \\
\text { concepções de } \\
\text { educação }\end{array}$ & Participantes & Ações & Método & $\begin{array}{l}\text { Objetivo(s) das } \\
\text { ações }\end{array}$ & $\begin{array}{l}\text { Mudanças } \\
\text { ocorridas }\end{array}$ \\
\hline & & & $\begin{array}{l}\text { forma a obter } \\
\text { maior } \\
\text { aproveitamento } \\
\text { das ações } \\
\text { implementadas }\end{array}$ & & & & & & \\
\hline $\begin{array}{l}\text { "Oficina itinerante } \\
\text { de gestão de } \\
\text { pessoas" }\end{array}$ & $\begin{array}{l}\text { Núcleo } \\
\text { Estadual do } \\
\text { Ministério da } \\
\text { Saúde no } \\
\text { Espírito Santo }\end{array}$ & 2014 & $\begin{array}{l}\text { [...] EPS - } \\
\text { dispositivo } \\
\text { estratégico de } \\
\text { transformação de } \\
\text { gestão no SUS [...] }\end{array}$ & $\begin{array}{l}\text { "... dispositivo } \\
\text { estratégico de } \\
\text { transformação de } \\
\text { gestão no Sistema } \\
\text { Único de Saúde } \\
\text { (SUS)..." }\end{array}$ & $\begin{array}{l}\text { Servidores cedidos, } \\
\text { suas chefias } \\
\text { imediatas e } \\
\text { gestores estaduais } \\
\text { e municipais. }\end{array}$ & $\begin{array}{l}\text { Oficina itinerante } \\
\text { de gestão de } \\
\text { pessoas. }\end{array}$ & \begin{tabular}{|l} 
Oficinas para \\
reflexão e \\
avaliação de \\
questões \\
problematizadas.
\end{tabular} & $\begin{array}{l}\text { Reflexão e } \\
\text { avaliação de } \\
\text { questões } \\
\text { problematizadas } \\
\text { para melhorar a } \\
\text { realidade do } \\
\text { trabalho. }\end{array}$ & $\begin{array}{l}\text { Os trabalhadores } \\
\text { reconheceram } \\
\text { que é possível } \\
\text { melhorar sua } \\
\text { realidade de } \\
\text { trabalho } \\
\text { assumindo o } \\
\text { papel de sujeito } \\
\text { da transformação, } \\
\text { a partir da } \\
\text { construção de } \\
\text { novas práticas } \\
\text { coletivas de } \\
\text { aprendizado no } \\
\text { trabalho, com o } \\
\text { trabalho e para o } \\
\text { trabalho. }\end{array}$ \\
\hline
\end{tabular}




\begin{tabular}{|c|c|c|c|c|c|c|c|c|c|}
\hline Narrativas & Local & Início & $\begin{array}{l}\text { Concepção de } \\
\text { educação } \\
\text { destacada no } \\
\text { texto }\end{array}$ & $\begin{array}{l}\text { Inferências a partir } \\
\text { de trechos das } \\
\text { narrativas que } \\
\text { correspondem a } \\
\text { concepções de } \\
\text { educação }\end{array}$ & Participantes & Ações & Método & $\begin{array}{l}\text { Objetivo(s) das } \\
\text { ações }\end{array}$ & $\begin{array}{l}\text { Mudanças } \\
\text { ocorridas }\end{array}$ \\
\hline $\begin{array}{l}\text { "Oficinas } \\
\text { itinerantes sobre a } \\
\text { avaliação de } \\
\text { desempenho no } \\
\text { INCA" }\end{array}$ & $\begin{array}{l}\text { Instituto } \\
\text { Nacional de } \\
\text { Câncer - Rio de } \\
\text { Janeiro }\end{array}$ & 2012 & $\begin{array}{l}\text { NÃO DECLARADA } \\
\text { EXPRESSAMENTE }\end{array}$ & \begin{tabular}{|l} 
Destaca termos \\
correlacionados à \\
Educação \\
Permanente em \\
Saúde como: \\
"estar junto", \\
"aprender junto", \\
"troca de \\
experiências" e \\
"aprendizado \\
coletivo".
\end{tabular} & $\begin{array}{l}\text { Servidores do } \\
\text { INCA. }\end{array}$ & $\begin{array}{l}\text { Palestras, reuniões, } \\
\text { materiais de } \\
\text { consulta (manuais } \\
\text { dos sistemas e } \\
\text { "perguntas e } \\
\text { respostas"), criação } \\
\text { de um espaço } \\
\text { específico na } \\
\text { intranet para } \\
\text { disponibilização } \\
\text { dos materiais } \\
\text { informativos } \\
\text { (legislação, } \\
\text { manuais, } \\
\text { cronogramas etc.), } \\
\text { divulgação das } \\
\text { ações, por meio de } \\
\text { e-mails e } \\
\text { postmaster, e } \\
\text { criação de um } \\
\text { endereço } \\
\text { eletrônico próprio } \\
\text { para tirar dúvidas. }\end{array}$ & Oficinas & $\begin{array}{l}\text { Levar aos } \\
\text { servidores } \\
\text { informações } \\
\text { relevantes } \\
\text { referentes aos } \\
\text { processos e aos } \\
\text { procedimentos } \\
\text { ligados à área de } \\
\text { Gestão de Pessoas } \\
\text { do INCA. }\end{array}$ & $\begin{array}{l}\text { Entre servidores e } \\
\text { gestores foram } \\
\text { atingidos } 65 \% \text { do } \\
\text { quadro de } \\
\text { pessoal, o que } \\
\text { corresponde a } \\
2.017 \text { pessoas } \\
\text { capacitadas, num } \\
\text { total de } 23 \\
\text { oficinas e quatro } \\
\text { materiais } \\
\text { informativos } \\
\text { específicos. As } \\
\text { oficinas } \\
\text { permitiram à área } \\
\text { de Gestão de } \\
\text { Pessoas a } \\
\text { identificação de } \\
\text { carência dos } \\
\text { servidores quanto } \\
\text { às informações } \\
\text { sobre } \\
\text { aposentadoria, } \\
\text { férias etc. }\end{array}$ \\
\hline
\end{tabular}




\begin{tabular}{|c|c|c|c|c|c|c|c|c|c|}
\hline Narrativas & Local & Início & $\begin{array}{l}\text { Concepção de } \\
\text { educação } \\
\text { destacada no } \\
\text { texto }\end{array}$ & $\begin{array}{l}\text { Inferências a partir } \\
\text { de trechos das } \\
\text { narrativas que } \\
\text { correspondem a } \\
\text { concepções de } \\
\text { educação }\end{array}$ & Participantes & Ações & Método & $\begin{array}{l}\text { Objetivo(s) das } \\
\text { ações }\end{array}$ & $\begin{array}{l}\text { Mudanças } \\
\text { ocorridas }\end{array}$ \\
\hline $\begin{array}{l}\text { "Prática de } \\
\text { governança na } \\
\text { Hemobrás: } \\
\text { estratégia de } \\
\text { avaliação de novos } \\
\text { empregados } \\
\text { públicos" }\end{array}$ & $\begin{array}{l}\text { Empresa } \\
\text { Brasileira de } \\
\text { Hemoderivados } \\
\text { e Biotecnologia } \\
\text { - Hemobrás }\end{array}$ & $\begin{array}{c}\text { Não foi } \\
\text { mencionado. }\end{array}$ & $\begin{array}{l}\text { [...] a metodologia } \\
\text { da Educação } \\
\text { Permanente em } \\
\text { Saúde agrega os } \\
\text { sujeitos com seus } \\
\text { saberes e suas } \\
\text { práticas e (re) } \\
\text { constrói os } \\
\text { saberes coletivos, } \\
\text { produzindo } \\
\text { mudanças de } \\
\text { práticas de gestão. }\end{array}$ & $\begin{array}{l}\text { "... a metodologia } \\
\text { da Educação } \\
\text { Permanente em } \\
\text { Saúde (EPS) agrega } \\
\text { os sujeitos com } \\
\text { seus saberes e } \\
\text { suas práticas e (re) } \\
\text { constrói os saberes } \\
\text { coletivos, } \\
\text { produzindo } \\
\text { mudanças de } \\
\text { práticas de } \\
\text { gestão." }\end{array}$ & $\begin{array}{l}\text { Novos empregados } \\
\text { da Hemobrás. }\end{array}$ & \begin{tabular}{|l|} 
Dispositivo de \\
gestão \\
desenvolvido na \\
perspectiva de \\
avaliar a \\
qualificação e o \\
desempenho dos \\
novos empregados \\
a partir das \\
habilidades \\
técnicas, \\
comportamentais e \\
condutas.
\end{tabular} & $\begin{array}{l}\text { A prática foi } \\
\text { desenvolvida por } \\
\text { várias mãos, a } \\
\text { partir de rodas de } \\
\text { discussão com os } \\
\text { trabalhadores e } \\
\text { gestores, tendo a } \\
\text { facilitação de uma } \\
\text { empresa de } \\
\text { consultoria. }\end{array}$ & $\begin{array}{l}\text { Qualificar e } \\
\text { desenvolver o } \\
\text { quadro funcional } \\
\text { da Hemobrás e } \\
\text { subsidiar a } \\
\text { efetivação ou não } \\
\text { destes ao final dos } \\
90 \text { dias de } \\
\text { experiência, } \\
\text { conforme } \\
\text { preconiza a CLT, } \\
\text { além de promover } \\
\text { o desenvolvimento } \\
\text { do empregado e } \\
\text { da equipe por } \\
\text { meio de ações } \\
\text { direcionadas para } \\
\text { suas necessidades } \\
\text { e habilidades a } \\
\text { serem } \\
\text { desenvolvidas ou } \\
\text { qualificadas. }\end{array}$ & $\begin{array}{l}\text { "O produto desse } \\
\text { trabalho foi um } \\
\text { instrumento de } \\
\text { avaliação, com } \\
\text { aceitação e } \\
\text { aplicabilidade por } \\
\text { todos os } \\
\text { envolvidos no } \\
\text { processo." }\end{array}$ \\
\hline $\begin{array}{l}\text { "Prática de } \\
\text { governança na } \\
\text { Hemobrás: } \\
\text { estratégia de } \\
\text { integração de } \\
\text { novos( as) } \\
\text { empregados(as) } \\
\text { públicos(as)" }\end{array}$ & $\begin{array}{l}\text { Empresa } \\
\text { Brasileira de } \\
\text { Hemoderivados } \\
\text { e Biotecnologia } \\
\text { - Hemobrás }\end{array}$ & $\begin{array}{c}\text { Não foi } \\
\text { mencionado. }\end{array}$ & $\begin{array}{l}\text { [...] a metodologia } \\
\text { da Educação } \\
\text { Permanente em } \\
\text { Saúde produz } \\
\text { saberes coletivos, } \\
\text { produzindo } \\
\text { mudanças de } \\
\text { práticas de gestão. }\end{array}$ & $\begin{array}{l}\text { "... a metodologia } \\
\text { da Educação } \\
\text { Permanente em } \\
\text { Saúde produz } \\
\text { saberes coletivos, } \\
\text { produzindo } \\
\text { mudanças de } \\
\text { práticas de }\end{array}$ & $\begin{array}{l}\text { Novos } \\
\text { trabalhadores da } \\
\text { Hemobrás }\end{array}$ & $\begin{array}{l}\text { Integração de } \\
\text { novos } \\
\text { trabalhadores da } \\
\text { Hemobrás. }\end{array}$ & $\begin{array}{l}\text { Apresentação das } \\
\text { áreas, dos } \\
\text { processos, das } \\
\text { rotinas de } \\
\text { trabalho e da } \\
\text { cultura } \\
\text { organizacional da } \\
\text { empresa, }\end{array}$ & $\begin{array}{l}\text { Identificar as } \\
\text { necessidades de } \\
\text { adaptação dos } \\
\text { empregados } \\
\text { públicos à cidade e } \\
\text { à empresa, } \\
\text { apresentando-lhes } \\
\text { a Hemobrás e }\end{array}$ & $\begin{array}{l}\text { A narrativa } \\
\text { apresenta } \\
\text { possíveis } \\
\text { resultados como: } \\
\text { favorecimento do } \\
\text { início do plano de } \\
\text { desenvolvimento } \\
\text { do trabalhador no }\end{array}$ \\
\hline
\end{tabular}




\begin{tabular}{|c|c|c|c|c|c|c|c|c|c|}
\hline Narrativas & Local & Início & $\begin{array}{l}\text { Concepção de } \\
\text { educação } \\
\text { destacada no } \\
\text { texto }\end{array}$ & $\begin{array}{l}\text { Inferências a partir } \\
\text { de trechos das } \\
\text { narrativas que } \\
\text { correspondem a } \\
\text { concepções de } \\
\text { educação }\end{array}$ & Participantes & Ações & Método & $\begin{array}{l}\text { Objetivo(s) das } \\
\text { ações }\end{array}$ & $\begin{array}{l}\text { Mudanças } \\
\text { ocorridas }\end{array}$ \\
\hline & & & & gestão." & & & \begin{tabular}{|l} 
alinhando com as \\
expectativas dos \\
novos servidores. \\
Concluído o \\
processo de \\
integração, inicia- \\
se o \\
desenvolvimento \\
profissional no \\
posto de trabalho, \\
por meio do plano \\
de \\
desenvolvimento \\
inicial, que é \\
elaborado com \\
base na descrição \\
de cargos e \\
competências do \\
cargo/emprego do \\
novo empregado \\
público, \\
objetivando \\
prepará-los para o \\
bom desempenho \\
de suas atividades.
\end{tabular} & $\begin{array}{l}\text { integrando-os à } \\
\text { rotina de trabalho } \\
\text { e aos processos, o } \\
\text { que facilita sua } \\
\text { socialização e seu } \\
\text { preparo para o } \\
\text { bom desempenho } \\
\text { das atividades } \\
\text { previstas. }\end{array}$ & $\begin{array}{l}\text { segmento da } \\
\text { indústria } \\
\text { farmacêutica, } \\
\text { incorporando em } \\
\text { sua prática } \\
\text { cotidiana o } \\
\text { aprendizado e o } \\
\text { conhecimento } \\
\text { mútuos. }\end{array}$ \\
\hline
\end{tabular}




\begin{tabular}{|c|c|c|c|c|c|c|c|c|c|}
\hline Narrativas & Local & Início & $\begin{array}{l}\text { Concepção de } \\
\text { educação } \\
\text { destacada no } \\
\text { texto }\end{array}$ & $\begin{array}{l}\text { Inferências a partir } \\
\text { de trechos das } \\
\text { narrativas que } \\
\text { correspondem a } \\
\text { concepções de } \\
\text { educação }\end{array}$ & Participantes & Ações & Método & $\begin{array}{l}\text { Objetivo(s) das } \\
\text { ações }\end{array}$ & $\begin{array}{l}\text { Mudanças } \\
\text { ocorridas }\end{array}$ \\
\hline $\begin{array}{l}\text { "Preparação para } \\
\text { aposentadoria: } \\
\text { vida que segue" }\end{array}$ & $\begin{array}{l}\text { Núcleo } \\
\text { Estadual do } \\
\text { Ministério da } \\
\text { Saúde no Rio } \\
\text { de Janeiro }\end{array}$ & $\begin{array}{c}\text { Não foi } \\
\text { mencionado. }\end{array}$ & $\begin{array}{l}{[\ldots . .] \text { ação que }} \\
\text { compartilha e } \\
\text { integra saberes em } \\
\text { aprendizado } \\
\text { constante, no qual } \\
\text { o conhecimento se } \\
\text { dá por meio da } \\
\text { troca com o outro } \\
{[\ldots . .]}\end{array}$ & $\begin{array}{l}\text { "... ação que } \\
\text { compartilha e } \\
\text { integra saberes em } \\
\text { aprendizado } \\
\text { constante, no qual } \\
\text { o conhecimento se } \\
\text { dá por meio da } \\
\text { troca com o } \\
\text { outro." } \\
\end{array}$ & $\begin{array}{l}\text { Servidores do } \\
\text { Núcleo Estadual do } \\
\text { Ministério da } \\
\text { Saúde no Rio de } \\
\text { Janeiro. }\end{array}$ & \begin{tabular}{|l|} 
Projeto preparação \\
para \\
aposentadoria; \\
encontros \\
reflexivos \\
(coletivos).
\end{tabular} & $\begin{array}{l}\text { Encontros } \\
\text { reflexivos } \\
\text { (coletivos) com a } \\
\text { finalidade de } \\
\text { preparar o } \\
\text { servidor para uma } \\
\text { nova fase de vida } \\
\text { (pós- } \\
\text { aposentadoria). } \\
\end{array}$ & $\begin{array}{l}\text { Formar e informar } \\
\text { sobre todos os } \\
\text { processos que } \\
\text { permeiam a } \\
\text { aposentadoria. }\end{array}$ & $\begin{array}{l}\text { Não foi possível } \\
\text { identificar as } \\
\text { mudanças } \\
\text { ocorridas a partir } \\
\text { da experiência } \\
\text { apresentada na } \\
\text { narrativa. }\end{array}$ \\
\hline $\begin{array}{l}\text { "Primeira oficina } \\
\text { de planejamento } \\
\text { de ações voltadas } \\
\text { para a melhoria } \\
\text { das atividades de } \\
\text { Educação } \\
\text { Permanente em } \\
\text { Saúde no } \\
\text { NEMS/PA" }\end{array}$ & $\begin{array}{l}\text { Núcleo } \\
\text { Estadual do } \\
\text { Ministério da } \\
\text { Saúde no Pará }\end{array}$ & $\begin{array}{c}\text { Não foi } \\
\text { mencionado. }\end{array}$ & $\begin{array}{l}\text { [...] que a } \\
\text { produção de } \\
\text { conhecimento } \\
\text { pode surgir no } \\
\text { local de trabalho, } \\
\text { não deve ser } \\
\text { somente } \\
\text { "importada" de } \\
\text { instituições } \\
\text { externas, mas, de } \\
\text { todo modo, cada } \\
\text { uma tem a sua } \\
\text { importância. }\end{array}$ & \begin{tabular}{|l|} 
"... a produção de \\
conhecimento \\
pode surgir no \\
local de trabalho; \\
não deve ser \\
somente \\
"importada" de \\
instituições \\
externas, mas, de \\
todo modo, cada \\
uma tem a sua \\
importância."
\end{tabular} & $\begin{array}{l}\text { Não fica claro na } \\
\text { narrativa, quem } \\
\text { são os } \\
\text { participantes da } \\
\text { ação desenvolvida. }\end{array}$ & $\begin{array}{l}\text { Não são detalhadas } \\
\text { na narrativa as } \\
\text { ações } \\
\text { desenvolvidas. }\end{array}$ & $\begin{array}{l}\text { Não se percebe o } \\
\text { método na } \\
\text { narrativa. }\end{array}$ & $\begin{array}{l}\text { Não se percebe os } \\
\text { objetivos das } \\
\text { ações na narrativa. }\end{array}$ & $\begin{array}{l}\text { Não foi possível } \\
\text { identificar as } \\
\text { mudanças } \\
\text { ocorridas a partir } \\
\text { da experiência } \\
\text { apresentada na } \\
\text { narrativa. }\end{array}$ \\
\hline
\end{tabular}




\begin{tabular}{|c|c|c|c|c|c|c|c|c|c|}
\hline Narrativas & Local & Início & $\begin{array}{l}\text { Concepção de } \\
\text { educação } \\
\text { destacada no } \\
\text { texto }\end{array}$ & $\begin{array}{l}\text { Inferências a partir } \\
\text { de trechos das } \\
\text { narrativas que } \\
\text { correspondem a } \\
\text { concepções de } \\
\text { educação }\end{array}$ & Participantes & Ações & Método & $\begin{array}{l}\text { Objetivo(s) das } \\
\text { ações }\end{array}$ & $\begin{array}{l}\text { Mudanças } \\
\text { ocorridas }\end{array}$ \\
\hline $\begin{array}{l}\text { "Projeto baião de } \\
\text { dois" }\end{array}$ & $\begin{array}{l}\text { Núcleo } \\
\text { Estadual do } \\
\text { Ministério da } \\
\text { Saúde na } \\
\text { Paraíba }\end{array}$ & $\begin{array}{c}\text { Não foi } \\
\text { mencionado. }\end{array}$ & \begin{tabular}{|l}
{$[.$.$] metodologia$} \\
sustentada na \\
construção \\
coletiva, utilizando \\
a técnica de \\
processos \\
participativos, \\
proporciona um \\
espaço de \\
discussão, em que \\
ideias \\
convergentes ou \\
conflitantes \\
resultam em \\
enriquecedora \\
troca de saberes, \\
fortalecendo o \\
grupo e \\
legitimando as \\
decisões.
\end{tabular} & $\begin{array}{l}\text { "... metodologia } \\
\text { sustentada na } \\
\text { construção } \\
\text { coletiva, utilizando } \\
\text { a técnica de } \\
\text { processos } \\
\text { participativos, } \\
\text { proporciona um } \\
\text { espaço de } \\
\text { discussão, em que } \\
\text { ideias } \\
\text { convergentes ou } \\
\text { conflitantes } \\
\text { resultam em } \\
\text { enriquecedora } \\
\text { troca de saberes, } \\
\text { fortalecendo o } \\
\text { grupo e } \\
\text { legitimando as } \\
\text { decisões." }\end{array}$ & $\begin{array}{l}\text { Servidores do } \\
\text { Núcleo Estadual do } \\
\text { Ministério da } \\
\text { Saúde na Paraíba. }\end{array}$ & \begin{tabular}{|l|} 
Reuniões e \\
encontros para \\
compartilhar \\
ideias. Práticas \\
educativas, com a \\
construção de \\
conhecimentos a \\
partir do sujeito e a \\
realidade do \\
trabalho, tendo \\
como pano de \\
fundo uma \\
concepção \\
freireana.
\end{tabular} & $\begin{array}{l}\text { Reuniões } \\
\text { pautadas no livre } \\
\text { pensar, seja na } \\
\text { escolha da } \\
\text { temática, seja na } \\
\text { condução, ou, } \\
\text { principalmente, } \\
\text { no resultado final, } \\
\text { haja vista que as } \\
\text { considerações } \\
\text { finais são } \\
\text { construídas por } \\
\text { consenso, pela } \\
\text { plenária. }\end{array}$ & $\begin{array}{l}\text { Enfrentamento das } \\
\text { constantes } \\
\text { mudanças, da } \\
\text { velocidade } \\
\text { vertiginosa das } \\
\text { informações e, } \\
\text { principalmente, } \\
\text { das insatisfações } \\
\text { geradas pelo } \\
\text { cotidiano do } \\
\text { trabalho. }\end{array}$ & $\begin{array}{l}\text { Não foi possível } \\
\text { identificar as } \\
\text { mudanças } \\
\text { ocorridas a partir } \\
\text { da experiência } \\
\text { apresentada na } \\
\text { narrativa. }\end{array}$ \\
\hline $\begin{array}{l}\text { "Projeto SETA: } \\
\text { sessão técnico- } \\
\text { administrativa" }\end{array}$ & $\begin{array}{l}\text { Núcleo } \\
\text { Estadual do } \\
\text { Ministério da } \\
\text { Saúde no Rio } \\
\text { Grande do } \\
\text { Norte }\end{array}$ & $\begin{array}{c}\text { Não foi } \\
\text { mencionado. }\end{array}$ & $\begin{array}{l}\text { NÃO DECLARADA } \\
\text { EXPRESSAMENTE }\end{array}$ & $\begin{array}{l}\text { "... maneiras } \\
\text { peculiares e } \\
\text { criativas de tentar } \\
\text { amenizar } \\
\text { dificuldades } \\
\text { encontradas com } \\
\text { os recursos } \\
\text { disponíveis, e que } \\
\text { são fortalecidas } \\
\text { pela vontade e }\end{array}$ & $\begin{array}{l}\text { Não fica claro na } \\
\text { narrativa, quem } \\
\text { são os } \\
\text { participantes da } \\
\text { ação desenvolvida. }\end{array}$ & $\begin{array}{l}\text { Não são detalhadas } \\
\text { na narrativa as } \\
\text { ações } \\
\text { desenvolvidas. }\end{array}$ & \begin{tabular}{|l|} 
Não foi \\
apresentado o \\
método utilizado.
\end{tabular} & $\begin{array}{l}\text { Não se percebe os } \\
\text { objetivos das } \\
\text { ações na narrativa. }\end{array}$ & $\begin{array}{l}\text { Não foi possível } \\
\text { identificar as } \\
\text { mudanças } \\
\text { ocorridas a partir } \\
\text { da experiência } \\
\text { apresentada na } \\
\text { narrativa. }\end{array}$ \\
\hline
\end{tabular}




\begin{tabular}{|c|c|c|c|c|c|c|c|c|c|}
\hline Narrativas & Local & Início & $\begin{array}{l}\text { Concepção de } \\
\text { educação } \\
\text { destacada no } \\
\text { texto }\end{array}$ & $\begin{array}{l}\text { Inferências a partir } \\
\text { de trechos das } \\
\text { narrativas que } \\
\text { correspondem a } \\
\text { concepções de } \\
\text { educação }\end{array}$ & Participantes & Ações & Método & $\begin{array}{l}\text { Objetivo(s) das } \\
\text { ações }\end{array}$ & $\begin{array}{l}\text { Mudanças } \\
\text { ocorridas }\end{array}$ \\
\hline & & & & $\begin{array}{l}\text { pela disposição de } \\
\text { servidores que } \\
\text { acreditam na } \\
\text { mudança." }\end{array}$ & & & & & \\
\hline $\begin{array}{l}\text { "Reflexões sobre a } \\
\text { formação como } \\
\text { dispositivo no } \\
\text { contexto da } \\
\text { Educação } \\
\text { Permanente em } \\
\text { Saúde" }\end{array}$ & $\begin{array}{l}\text { Secretaria de } \\
\text { Atenção à } \\
\text { Saúde do } \\
\text { Ministério da } \\
\text { Saúde }\end{array}$ & $\begin{array}{c}\text { Não foi } \\
\text { mencionado. }\end{array}$ & $\begin{array}{l}\text { [...] EPS como um } \\
\text { fio condutor que } \\
\text { se expressa no } \\
\text { potencial } \\
\text { transformador da } \\
\text { experimentação e } \\
\text { do encontro, do } \\
\text { olho no olho, que } \\
\text { permite a } \\
\text { propagação de } \\
\text { uma onda de } \\
\text { intensidades } \\
\text { diversas, a partir } \\
\text { da ressignificação } \\
\text { que cada } \\
\text { profissional faz. }\end{array}$ & $\begin{array}{l}\text { "... processo de } \\
\text { experimentar, } \\
\text { vivenciar e se } \\
\text { apropriar de um } \\
\text { saber implíito que } \\
\text { passa a fazer parte } \\
\text { de nossa maleta." } \\
\text { "...fio condutor } \\
\text { que se expressa no } \\
\text { potencial } \\
\text { transformador da } \\
\text { experimentação e } \\
\text { do encontro, do } \\
\text { olho no olho, que } \\
\text { permite a } \\
\text { propagação de } \\
\text { uma onda de } \\
\text { intensidades } \\
\text { diversas, a partir } \\
\text { da ressignificação } \\
\text { que cada } \\
\text { profissional faz." }\end{array}$ & $\begin{array}{l}\text { Não fica claro na } \\
\text { narrativa, quem } \\
\text { são os } \\
\text { participantes da } \\
\text { ação desenvolvida. }\end{array}$ & $\begin{array}{l}\text { Consultoria em } \\
\text { saúde da criança. }\end{array}$ & $\begin{array}{l}\text { Trabalhos em } \\
\text { grupo. }\end{array}$ & $\begin{array}{l}\text { Não se percebe os } \\
\text { objetivos das } \\
\text { ações na narrativa. }\end{array}$ & $\begin{array}{l}\text { Não foi possível } \\
\text { identificar as } \\
\text { mudanças } \\
\text { ocorridas a partir } \\
\text { da experiência } \\
\text { apresentada na } \\
\text { narrativa. }\end{array}$ \\
\hline
\end{tabular}




\begin{tabular}{|c|c|c|c|c|c|c|c|c|c|}
\hline Narrativas & Local & Início & $\begin{array}{l}\text { Concepção de } \\
\text { educação } \\
\text { destacada no } \\
\text { texto }\end{array}$ & $\begin{array}{l}\text { Inferências a partir } \\
\text { de trechos das } \\
\text { narrativas que } \\
\text { correspondem a } \\
\text { concepções de } \\
\text { educação }\end{array}$ & Participantes & Ações & Método & $\begin{array}{l}\text { Objetivo(s) das } \\
\text { ações }\end{array}$ & $\begin{array}{l}\text { Mudanças } \\
\text { ocorridas }\end{array}$ \\
\hline $\begin{array}{l}\text { "Reunião ampliada } \\
\text { de redes: espaço } \\
\text { coletivo de } \\
\text { integração das } \\
\text { redes temáticas no } \\
\text { Estado do Espírito } \\
\text { Santo" }\end{array}$ & $\begin{array}{l}\text { Secretaria de } \\
\text { Atenção à } \\
\text { Saúde do } \\
\text { Ministério da } \\
\text { Saúde }\end{array}$ & 2012 & $\begin{array}{l}\text { NÃO DECLARADA } \\
\text { EXPRESSAMENTE }\end{array}$ & $\begin{array}{l}\text { Destacas termos } \\
\text { correlacionados à } \\
\text { Educação } \\
\text { Permanente em } \\
\text { Saúde como } \\
\text { cogestão, por } \\
\text { exemplo. }\end{array}$ & $\begin{array}{l}\text { Atores estratégicos } \\
\text { da Secretaria de } \\
\text { Estado da Saúde } \\
\text { do ES e apoio } \\
\text { institucional do } \\
\text { Ministério da } \\
\text { Saúde. }\end{array}$ & $\begin{array}{l}\text { Reunião ampliada } \\
\text { de redes. }\end{array}$ & $\begin{array}{l}\text { As pautas das } \\
\text { reuniões } \\
\text { ampliadas de } \\
\text { redes são } \\
\text { sugeridas a partir } \\
\text { das observações } \\
\text { do apoiador de } \\
\text { articulação de } \\
\text { Redes com pontos } \\
\text { de discussão } \\
\text { comuns entre } \\
\text { elas. }\end{array}$ & $\begin{array}{l}\text { Fomentar a } \\
\text { articulação e a } \\
\text { integração entre o } \\
\text { coletivo do apoio } \\
\text { institucional do } \\
\text { Ministério da } \\
\text { Saúde para o } \\
\text { estado e as cinco } \\
\text { redes temáticas } \\
\text { priorizadas pelo } \\
\text { MS: Rede de } \\
\text { Atenção às } \\
\text { Urgências e } \\
\text { Emergências, Rede } \\
\text { Cegonha, Rede de } \\
\text { Cuidado à Pessoa } \\
\text { com Deficiência, } \\
\text { Rede de Atenção } \\
\text { Psicossocial e Rede } \\
\text { de Atenção à } \\
\text { Saúde das Pessoas } \\
\text { com Doenças } \\
\text { Crônicas. }\end{array}$ & $\begin{array}{l}\text { A iniciativa vem } \\
\text { oportunizando } \\
\text { melhores } \\
\text { articulação e } \\
\text { integração das } \\
\text { redes temáticas } \\
\text { no Espírito Santo, } \\
\text { provocando } \\
\text { ampla discussão } \\
\text { do modelo de } \\
\text { organização e de } \\
\text { gestão do SUS em } \\
\text { rede. As reuniões } \\
\text { tornaram-se um } \\
\text { potente espaço } \\
\text { coletivo de } \\
\text { integração, de } \\
\text { aproximação de } \\
\text { diversas áreas } \\
\text { técnicas, de } \\
\text { atualização, } \\
\text { compartilhamento } \\
\text { e divulgação de } \\
\text { informações de } \\
\text { todas as redes } \\
\text { temáticas, além } \\
\text { do fomento de } \\
\text { movimentos para } \\
\text { soluções de } \\
\text { problemas } \\
\text { comuns, com }\end{array}$ \\
\hline
\end{tabular}




\begin{tabular}{|c|c|c|c|c|c|c|c|c|c|}
\hline Narrativas & Local & Início & $\begin{array}{l}\text { Concepção de } \\
\text { educação } \\
\text { destacada no } \\
\text { texto }\end{array}$ & $\begin{array}{l}\text { Inferências a partir } \\
\text { de trechos das } \\
\text { narrativas que } \\
\text { correspondem a } \\
\text { concepções de } \\
\text { educação }\end{array}$ & Participantes & Ações & Método & $\begin{array}{l}\text { Objetivo(s) das } \\
\text { ações }\end{array}$ & $\begin{array}{l}\text { Mudanças } \\
\text { ocorridas }\end{array}$ \\
\hline & & & & & & & & & $\begin{array}{l}\text { grande potencial } \\
\text { de serem } \\
\text { reproduzidos em } \\
\text { qualquer } \\
\text { território } \\
\text { nacional. }\end{array}$ \\
\hline $\begin{array}{l}\text { "Roda de conversa: } \\
\text { um dispositivo } \\
\text { potente de } \\
\text { mudança das } \\
\text { práticas na lógica } \\
\text { da Educação } \\
\text { Permanente em } \\
\text { Saúde - a } \\
\text { experiência das } \\
\text { maternidades } \\
\text { prioritárias da } \\
\text { Rede Cegonha no } \\
\text { Rio de Janeiro" }\end{array}$ & $\begin{array}{l}\text { Secretaria de } \\
\text { Atenção à } \\
\text { Saúde do } \\
\text { Ministério da } \\
\text { Saúde }\end{array}$ & 2013 & $\begin{array}{l}\text { NÃO DECLARADA } \\
\text { EXPRESSAMENTE }\end{array}$ & $\begin{array}{l}\text { Destaca termos } \\
\text { correlacionados à } \\
\text { Educação } \\
\text { Permanente em } \\
\text { Saúde como: } \\
\text { cogestão, } \\
\text { construção } \\
\text { coletiva e reflexão } \\
\text { sobre as práticas } \\
\text { no cotidiano dos } \\
\text { serviços. }\end{array}$ & $\begin{array}{l}\text { Gestores e } \\
\text { trabalhadores de } \\
\text { saúde. }\end{array}$ & $\begin{array}{l}\text { Reuniões mensais, } \\
\text { visitas técnicas e } \\
\text { rodas de conversa. }\end{array}$ & $\begin{array}{l}\text { Utilização da roda } \\
\text { como dispositivo } \\
\text { de reflexão sobre } \\
\text { as práticas no } \\
\text { cotidiano dos } \\
\text { serviços. }\end{array}$ & $\begin{array}{l}\text { Melhoria do } \\
\text { modelo de } \\
\text { atenção ao parto e } \\
\text { ao nascimento } \\
\text { preconizado pela } \\
\text { Rede Cegonha, } \\
\text { ação } \\
\text { interfederativa } \\
\text { que envolveu o } \\
\text { Ministério da } \\
\text { Saúde e as } \\
\text { secretarias de } \\
\text { saúde. }\end{array}$ & \begin{tabular}{|l} 
"O método de \\
atuar em equipe \\
ou em cogestão, \\
valorizando a \\
roda, representou \\
um movimento \\
contra- \\
hegemônico à \\
política de ações \\
verticalizadas, e \\
buscou a \\
construção \\
coletiva de ações \\
de enfrentamento \\
das dificuldades \\
trazidas e o \\
desafio de \\
redução da \\
mortalidade \\
materna e \\
neonatal no \\
Estado do Rio de \\
Janeiro. Segundo \\
os membros do \\
\end{tabular} \\
\hline
\end{tabular}




\begin{tabular}{|c|c|c|c|c|c|c|c|c|c|}
\hline Narrativas & Local & Início & $\begin{array}{l}\text { Concepção de } \\
\text { educação } \\
\text { destacada no } \\
\text { texto }\end{array}$ & $\begin{array}{l}\text { Inferências a partir } \\
\text { de trechos das } \\
\text { narrativas que } \\
\text { correspondem a } \\
\text { concepções de } \\
\text { educação }\end{array}$ & Participantes & Ações & Método & $\begin{array}{l}\text { Objetivo(s) das } \\
\text { ações }\end{array}$ & $\begin{array}{l}\text { Mudanças } \\
\text { ocorridas }\end{array}$ \\
\hline & & & & & & & & & $\begin{array}{l}\text { grupo, esse } \\
\text { dispositivo foi } \\
\text { considerado } \\
\text { potente para } \\
\text { promover a magia } \\
\text { do encontro e } \\
\text { induzir as } \\
\text { mudanças } \\
\text { necessárias." }\end{array}$ \\
\hline $\begin{array}{l}\text { "Rodas de } \\
\text { conversa: uma } \\
\text { forma de refletir e } \\
\text { dialogar sobre o } \\
\text { trabalho em } \\
\text { saúde" }\end{array}$ & $\begin{array}{l}\text { Secretaria de } \\
\text { Vigilância em } \\
\text { Saúde do } \\
\text { Ministério da } \\
\text { Saúde }\end{array}$ & 2013 & $\begin{array}{l}\text { NÃO DECLARADA } \\
\text { EXPRESSAMENTE }\end{array}$ & $\begin{array}{l}\text { Destaca termos } \\
\text { correlacionados à } \\
\text { Educação } \\
\text { Permanente em } \\
\text { Saúde. }\end{array}$ & $\begin{array}{l}\text { Trabalhadores do } \\
\text { Departamento de } \\
\text { DST, Aids e } \\
\text { Hepatites Virais } \\
\text { (DDAHV) e, em } \\
\text { alguns momentos, } \\
\text { trabalhadores de } \\
\text { toda a Secretaria } \\
\text { de Vigilância em } \\
\text { Saúde e demais } \\
\text { unidades do } \\
\text { Ministério da } \\
\text { Saúde. }\end{array}$ & Rodas de conversa. & $\begin{array}{l}\text { Nas rodas de } \\
\text { conversa são } \\
\text { promovidos } \\
\text { espaços de } \\
\text { diálogo e troca de } \\
\text { experiências de } \\
\text { forma crítica e } \\
\text { reflexiva. }\end{array}$ & $\begin{array}{l}\text { ".... estimular o } \\
\text { compartilhamento } \\
\text { e a socialização } \\
\text { das experiências e } \\
\text { das aç̃̃es } \\
\text { desenvolvidas } \\
\text { pelas áreas } \\
\text { técnicas, } \\
\text { proporcionando a } \\
\text { difusão de } \\
\text { conhecimento } \\
\text { teórico e prático } \\
\text { produzido no } \\
\text { DDAHV - e outros } \\
\text { setores do MS - } \\
\text { num espaço } \\
\text { permanente de } \\
\text { reflexão, } \\
\text { estimulando o } \\
\text { estabelecimento } \\
\text { de vínculos }\end{array}$ & $\begin{array}{l}\text { "Os resultados das } \\
\text { avaliações } \\
\text { indicam satisfação } \\
\text { por parte dos } \\
\text { servidores e dos } \\
\text { técnicos que } \\
\text { participaram das } \\
\text { rodas, a exemplo } \\
\text { da possibilidade } \\
\text { de trocas entre as } \\
\text { áreas técnicas, da } \\
\text { possibilidade de } \\
\text { conhecer melhor } \\
\text { o objeto de } \\
\text { trabalho, bem } \\
\text { como do } \\
\text { reconhecimento } \\
\text { da roda como } \\
\text { espaço potente } \\
\text { para indicar } \\
\text { pautas e aspectos }\end{array}$ \\
\hline
\end{tabular}




\begin{tabular}{|c|c|c|c|c|c|c|c|c|c|}
\hline \multirow[t]{2}{*}{ Narrativas } & \multirow[t]{2}{*}{ Local } & \multirow[t]{2}{*}{ Início } & \multirow[t]{2}{*}{$\begin{array}{l}\text { Concepção de } \\
\text { educação } \\
\text { destacada no } \\
\text { texto }\end{array}$} & \multirow[t]{2}{*}{$\begin{array}{l}\text { Inferências a partir } \\
\text { de trechos das } \\
\text { narrativas que } \\
\text { correspondem a } \\
\text { concepções de } \\
\text { educação }\end{array}$} & \multirow[t]{2}{*}{ Participantes } & \multirow[t]{2}{*}{ Ações } & \multirow[t]{2}{*}{ Método } & \multirow{2}{*}{\begin{tabular}{l}
\multicolumn{1}{c}{ Objetivo(s) das } \\
$\qquad$ ações \\
solidários, \\
integração, \\
autonomia e \\
protagonismo dos \\
trabalhadores."
\end{tabular}} & \multirow{2}{*}{\begin{tabular}{|l}
\multicolumn{1}{|c}{$\begin{array}{c}\text { Mudanças } \\
\text { ocorridas }\end{array}$} \\
a serem \\
incorporados à \\
rotina das \\
próprias rodas e \\
dos processos de \\
trabalho."
\end{tabular}} \\
\hline & & & & & & & & & \\
\hline $\begin{array}{l}\text { "Roteiro de análise } \\
\text { de convênios do } \\
\text { SICONV" }\end{array}$ & $\begin{array}{l}\text { Núcleo } \\
\text { Estadual do } \\
\text { Ministério da } \\
\text { Saúde na Bahia }\end{array}$ & $\begin{array}{c}\text { Não foi } \\
\text { mencionado. }\end{array}$ & 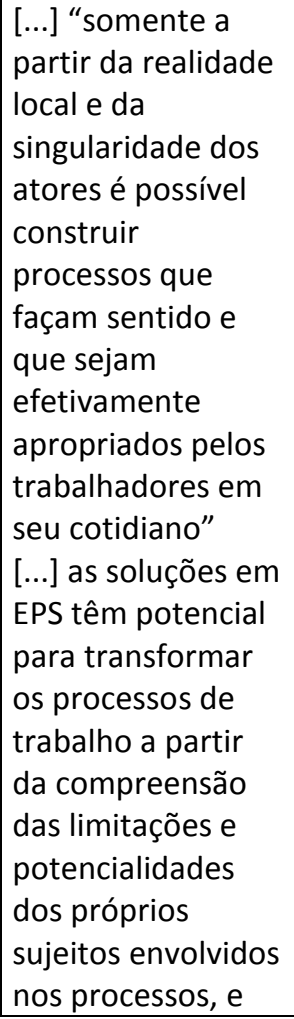 & $\begin{array}{l}\text { "... somente a } \\
\text { partir da realidade } \\
\text { local e da } \\
\text { singularidade dos } \\
\text { atores é possível } \\
\text { construir } \\
\text { processos que } \\
\text { façam sentido e } \\
\text { que sejam } \\
\text { efetivamente } \\
\text { apropriados pelos } \\
\text { trabalhadores em } \\
\text { seu cotidiano." } \\
\text { "...as soluções em } \\
\text { EPS têm potencial } \\
\text { para transformar } \\
\text { os processos de } \\
\text { trabalho a partir } \\
\text { da compreensão } \\
\text { das limitações e } \\
\text { das } \\
\text { potencialidades } \\
\text { dos próprios } \\
\text { sujeitos envolvidos }\end{array}$ & $\begin{array}{l}\text { Trabalhadores do } \\
\text { Serviço de } \\
\text { Convênios do } \\
\text { Núcleo Estadual do } \\
\text { Ministério da } \\
\text { Saúde na Bahia. }\end{array}$ & $\begin{array}{l}\text { Oficina de análise } \\
\text { de convênios do } \\
\text { SICONV. }\end{array}$ & $\begin{array}{l}\text { Inicialmente, } \\
\text { foram organizados } \\
\text { dois grupos, } \\
\text { incluindo } \\
\text { trabalhadores } \\
\text { responsáveis por } \\
\text { todas as etapas do } \\
\text { convênio e não } \\
\text { apenas os } \\
\text { analistas. Cada } \\
\text { grupo ficou } \\
\text { responsável por } \\
\text { analisar } \\
\text { coletivamente três } \\
\text { convênios do } \\
\text { passivo, com a } \\
\text { facilitação de um } \\
\text { dos dois } \\
\text { servidores que } \\
\text { tinham sido } \\
\text { capacitados em } \\
\text { todos os cursos do } \\
\text { SICONV } \\
\text { promovidos pelo }\end{array}$ & $\begin{array}{l}\text { Desenvolver um } \\
\text { modelo para } \\
\text { análise de } \\
\text { convênios. } \\
\\
\\
\end{array}$ & \begin{tabular}{|l} 
Foi desenvolvido \\
um modelo \\
nacional para a \\
análise de \\
convênios como \\
ferramenta de \\
orientação, \\
checagem de \\
análise e previsão \\
de todos os itens \\
pertinentes. "... os \\
instrumentos \\
criados \\
solucionaram as \\
dúvidas e as \\
dificuldades dos \\
servidores e \\
trouxeram \\
segurança aos \\
trabalhos." Houve \\
aumento da \\
produtividade e \\
resolutividade em \\
$100 \%$ dos casos,
\end{tabular} \\
\hline
\end{tabular}




\begin{tabular}{|c|c|c|c|c|c|c|c|c|c|}
\hline Narrativas & Local & Início & $\begin{array}{l}\text { Concepção de } \\
\text { educação } \\
\text { destacada no } \\
\text { texto }\end{array}$ & $\begin{array}{l}\text { Inferências a partir } \\
\text { de trechos das } \\
\text { narrativas que } \\
\text { correspondem a } \\
\text { concepções de } \\
\text { educação }\end{array}$ & Participantes & Ações & Método & $\begin{array}{l}\text { Objetivo(s) das } \\
\text { ações }\end{array}$ & $\begin{array}{l}\text { Mudanças } \\
\text { ocorridas }\end{array}$ \\
\hline & & & $\begin{array}{l}\text { da busca da } \\
\text { construção } \\
\text { coletiva de } \\
\text { alternativas, } \\
\text { desenvolvendo, na } \\
\text { prática, mais } \\
\text { habilidades e } \\
\text { autonomia dos } \\
\text { sujeitos. }\end{array}$ & $\begin{array}{l}\text { nos processos, e } \\
\text { da busca da } \\
\text { construção } \\
\text { coletiva de } \\
\text { alternativas, } \\
\text { desenvolvendo, na } \\
\text { prática, mais } \\
\text { habilidades e } \\
\text { autonomia dos } \\
\text { sujeitos." }\end{array}$ & & & $\begin{array}{l}\text { MS até então. } \\
\text { Houve um } \\
\text { compartilhamento } \\
\text { teórico do check } \\
\text { list e do roteiro de } \\
\text { análise proposto } \\
\text { pelo MS, seguido } \\
\text { de exploração } \\
\text { coletiva de cada } \\
\text { convênio para } \\
\text { identificar as } \\
\text { situações gerais } \\
\text { deles e as } \\
\text { dificuldades de } \\
\text { análise } \\
\text { evidenciadas pelas } \\
\text { limitações de } \\
\text { entendimentos } \\
\text { dos componentes } \\
\text { de cada grupo. }\end{array}$ & & $\begin{array}{l}\text { os analistas } \\
\text { desenvolveram } \\
\text { autonomia e } \\
\text { passaram a } \\
\text { solucionar os } \\
\text { casos } \\
\text { identificados pela } \\
\text { aplicação do } \\
\text { roteiro } \\
\text { diretamente com } \\
\text { os convenentes. }\end{array}$ \\
\hline $\begin{array}{l}\text { "Sarau literário no } \\
\text { NERJ" }\end{array}$ & $\begin{array}{l}\text { Núcleo } \\
\text { Estadual do } \\
\text { Ministério da } \\
\text { Saúde no Rio } \\
\text { de Janeiro }\end{array}$ & 2009 & $\begin{array}{l}\text { [...] educar implica } \\
\text { em trocar. Trocar } \\
\text { saberes: aluno e } \\
\text { mestre são } \\
\text { alicerces de igual } \\
\text { peso na dinâmica } \\
\text { instituída pela } \\
\text { Educação } \\
\text { Permanente em } \\
\text { Saúde. }\end{array}$ & $\begin{array}{l}\text { "... mais do que } \\
\text { passar } \\
\text { conhecimento, } \\
\text { educar implica } \\
\text { trocar. Trocar } \\
\text { saberes: aluno e } \\
\text { mestre são } \\
\text { alicerces de igual } \\
\text { peso na dinâmica } \\
\text { instituída pela }\end{array}$ & $\begin{array}{l}\text { Servidores do } \\
\text { Núcleo Estadual do } \\
\text { Ministério da } \\
\text { Saúde no Rio de } \\
\text { Janeiro e dos } \\
\text { hospitais federais. }\end{array}$ & Sarau literário & $\begin{array}{l}\text { "... o Sarau } \\
\text { experimenta } \\
\text { encontros - } \\
\text { abrindo espaço } \\
\text { para "artistas- } \\
\text { trabalhadores" } \\
\text { apresentarem } \\
\text { produções } \\
\text { próprias e } \\
\text { inovadoras, bem }\end{array}$ & $\begin{array}{l}\text { Oferecer aos } \\
\text { servidores do } \\
\text { Núcleo Estadual do } \\
\text { Ministério da } \\
\text { Saúde no Rio de } \\
\text { Janeiro e dos } \\
\text { hospitais federais } \\
\text { um contato com a } \\
\text { poesia dos } \\
\text { principais poetas }\end{array}$ & $\begin{array}{l}\text { Não foi possível } \\
\text { identificar as } \\
\text { mudanças } \\
\text { ocorridas a partir } \\
\text { da experiência } \\
\text { apresentada na } \\
\text { narrativa. }\end{array}$ \\
\hline
\end{tabular}




\begin{tabular}{|c|c|c|c|c|c|c|c|c|c|}
\hline Narrativas & Local & Início & $\begin{array}{l}\text { Concepção de } \\
\text { educação } \\
\text { destacada no } \\
\text { texto }\end{array}$ & $\begin{array}{l}\text { Inferências a partir } \\
\text { de trechos das } \\
\text { narrativas que } \\
\text { correspondem a } \\
\text { concepções de } \\
\text { educação }\end{array}$ & Participantes & Ações & Método & $\begin{array}{l}\text { Objetivo(s) das } \\
\text { ações }\end{array}$ & $\begin{array}{l}\text { Mudanças } \\
\text { ocorridas }\end{array}$ \\
\hline & & & & $\begin{array}{l}\text { Educação } \\
\text { Permanente em } \\
\text { Saúde." }\end{array}$ & & & $\begin{array}{l}\text { como terem } \\
\text { contato com } \\
\text { escritores } \\
\text { consagrados." }\end{array}$ & $\begin{array}{l}\text { do Brasil e do } \\
\text { mundo, bem como } \\
\text { estimular a } \\
\text { produção de } \\
\text { textos destes } \\
\text { trabalhadores. }\end{array}$ & \\
\hline $\begin{array}{l}\text { "Sujeitos em } \\
\text { construção } \\
\text { permanente" }\end{array}$ & $\begin{array}{l}\text { Núcleo } \\
\text { Estadual do } \\
\text { Ministério da } \\
\text { Saúde no } \\
\text { Paraná }\end{array}$ & $\begin{array}{c}\text { Não foi } \\
\text { mencionado. }\end{array}$ & $\begin{array}{l}\text { NÃO DECLARADA } \\
\text { EXPRESSAMENTE }\end{array}$ & \begin{tabular}{|l} 
"... proposta \\
atraente e \\
significativa na \\
medida em que \\
não "objetifica" o \\
trabalhador, ou \\
seja, não lhe \\
sugere a \\
passividade diante \\
de uma máquina \\
ou um sistema, \\
mas o torna \\
sujeito, isto é, lhe \\
propõe a autoria \\
de seu cotidiano."
\end{tabular} & $\begin{array}{l}\text { Trabalhadores do } \\
\text { Núcleo Estadual do } \\
\text { Ministério da } \\
\text { Saúde no } \\
\text { Tocantins. }\end{array}$ & Oficinas & $\begin{array}{l}\text { Nos encontros são } \\
\text { apresentadas e } \\
\text { debatidas } \\
\text { informações } \\
\text { relacionadas à } \\
\text { criação e à } \\
\text { implantação do } \\
\text { SUS, incluindo sua } \\
\text { constituição } \\
\text { política com a } \\
\text { abordagem de } \\
\text { conceitos como os } \\
\text { de democracia e } \\
\text { cidadania, a } \\
\text { reflexão ativa } \\
\text { acerca da } \\
\text { conceituação de } \\
\text { saúde e doença, } \\
\text { com suas } \\
\text { implicações na } \\
\text { prestação de } \\
\text { serviços de saúde, } \\
\text { perpassando todo } \\
\text { o momento de }\end{array}$ & \begin{tabular}{|l} 
Proporcionar \\
maior \\
conhecimento \\
acerca do Sistema \\
Único de Saúde, \\
propondo uma \\
reflexão sobre a \\
ebulição \\
micropolítica do \\
ambiente de \\
trabalho no Núcleo \\
Estadual do \\
Ministério da \\
Saúde no Paraná.
\end{tabular} & $\begin{array}{l}\text { Não foi possível } \\
\text { identificar as } \\
\text { mudanças } \\
\text { ocorridas a partir } \\
\text { da experiência } \\
\text { apresentada na } \\
\text { narrativa. }\end{array}$ \\
\hline
\end{tabular}




\begin{tabular}{|c|c|c|c|c|c|c|c|c|c|}
\hline Narrativas & Local & Início & $\begin{array}{l}\text { Concepção de } \\
\text { educação } \\
\text { destacada no } \\
\text { texto }\end{array}$ & $\begin{array}{l}\text { Inferências a partir } \\
\text { de trechos das } \\
\text { narrativas que } \\
\text { correspondem a } \\
\text { concepções de } \\
\text { educação }\end{array}$ & Participantes & Ações & Método & $\begin{array}{l}\text { Objetivo(s) das } \\
\text { ações }\end{array}$ & $\begin{array}{l}\text { Mudanças } \\
\text { ocorridas }\end{array}$ \\
\hline & & & & & & & & & $\begin{array}{l}\text { Saúde dos } \\
\text { profissionais da } \\
\text { rede municipal de } \\
\text { Natal (RN); e } \\
\text { fortalecimento } \\
\text { das relações } \\
\text { interfederativas, } \\
\text { bem como das } \\
\text { ações de EPS nos } \\
\text { territórios (MS, } \\
\text { SES e SMS). }\end{array}$ \\
\hline $\begin{array}{l}\text { "Videoconferências } \\
\text { da Rede Cegonha: } \\
\text { uma estratégia de } \\
\text { Educacão } \\
\text { Permanente em } \\
\text { Saúde no SUS" }\end{array}$ & $\begin{array}{l}\text { Secretaria de } \\
\text { Atenção à } \\
\text { Saúde do } \\
\text { Ministério da } \\
\text { Saúde }\end{array}$ & $\begin{array}{c}\text { Não foi } \\
\text { mencionado. }\end{array}$ & $\begin{array}{l}\text { NÃO DECLARADA } \\
\text { EXPRESSAMENTE }\end{array}$ & \begin{tabular}{|l} 
Destaca alguns \\
termos \\
correlacionados à \\
Educação \\
Permanente em \\
Saúde como: \\
reflexão das \\
práticas a partir da \\
problematização \\
de vivências \\
concretas e \\
possibilidades de \\
construção de \\
soluções e \\
estratégias.
\end{tabular} & $\begin{array}{l}\text { Não fica claro na } \\
\text { narrativa, quem } \\
\text { são os } \\
\text { participantes da } \\
\text { ação desenvolvida, } \\
\text { mas destaca a } \\
\text { participação de } \\
\text { atores diversos de } \\
\text { estados e } \\
\text { municípios. }\end{array}$ & $\begin{array}{l}\text { Videoconferências } \\
\text { da Rede Cegonha }\end{array}$ & $\begin{array}{l}\text { Uso de } \\
\text { videoconferências } \\
\text { como espaço de } \\
\text { aprendizagem. }\end{array}$ & $\begin{array}{l}\text { Problematização e } \\
\text { compartilhamento } \\
\text { de experiências } \\
\text { entre estados e } \\
\text { municípios na } \\
\text { implementação } \\
\text { das ações e das } \\
\text { estratégias da } \\
\text { Rede Cegonha. }\end{array}$ & $\begin{array}{l}\text { Não foi possível } \\
\text { identificar as } \\
\text { mudanças } \\
\text { ocorridas a partir } \\
\text { da experiência } \\
\text { apresentada na } \\
\text { narrativa. }\end{array}$ \\
\hline
\end{tabular}




\begin{tabular}{|c|c|c|c|c|c|c|c|c|c|}
\hline Narrativas & Local & Início & $\begin{array}{l}\text { Concepção de } \\
\text { educação } \\
\text { destacada no } \\
\text { texto }\end{array}$ & $\begin{array}{l}\text { Inferências a partir } \\
\text { de trechos das } \\
\text { narrativas que } \\
\text { correspondem a } \\
\text { concepções de } \\
\text { educação }\end{array}$ & Participantes & Ações & Método & $\begin{array}{l}\text { Objetivo(s) das } \\
\text { ações }\end{array}$ & $\begin{array}{l}\text { Mudanças } \\
\text { ocorridas }\end{array}$ \\
\hline $\begin{array}{l}\text { "Videoconferência } \\
\text { como recurso de } \\
\text { educação } \\
\text { permanente na } \\
\text { fisioterapia do } \\
\text { INCA" }\end{array}$ & $\begin{array}{l}\text { Instituto } \\
\text { Nacional de } \\
\text { Câncer - Rio de } \\
\text { Janeiro }\end{array}$ & 2012 & $\begin{array}{l}{[\ldots . .] \text { "pode estar no }} \\
\text { fazer de qualquer } \\
\text { um e que estamos } \\
\text { todos imersos } \\
\text { nela" e no "olho } \\
\text { vibrátil" que vem } \\
\text { se tornando } \\
\text { realidade. }\end{array}$ & $\begin{array}{l}\text { "... pode estar no } \\
\text { fazer de qualquer } \\
\text { um e que estamos } \\
\text { todos imersos nela } \\
\text { e no "olho vibrátil" } \\
\text { que vem se } \\
\text { tornando } \\
\text { realidade." }\end{array}$ & \begin{tabular}{|l} 
Profissionais do \\
Instituto Nacional \\
de Câncer.
\end{tabular} & Videoconferências & $\begin{array}{l}\text { Nas } \\
\text { videoconferências } \\
\text { são abordados } \\
\text { temas atuais } \\
\text { imersos na } \\
\text { oncologia, além } \\
\text { de políticas } \\
\text { públicas e temas } \\
\text { afins com duração } \\
\text { média de } 2 \text { horas. } \\
\text { São realizadas } \\
\text { gravações } \\
\text { experimentais, } \\
\text { possibilitando } \\
\text { consenso entre os } \\
\text { profissionais e } \\
\text { facilitando o seu } \\
\text { acesso em outros } \\
\text { horários. }\end{array}$ & $\begin{array}{l}\text { Integrar as } \\
\text { unidades } \\
\text { hospitalares do } \\
\text { Instituto Nacional } \\
\text { de Câncer, trocar } \\
\text { conhecimentos e } \\
\text { otimizar o tempo } \\
\text { dos profissionais } \\
\text { na linha de } \\
\text { cuidados do } \\
\text { câncer. }\end{array}$ & $\begin{array}{l}\text { Não foi possível } \\
\text { identificar as } \\
\text { mudanças } \\
\text { ocorridas a partir } \\
\text { da experiência } \\
\text { apresentada na } \\
\text { narrativa. }\end{array}$ \\
\hline
\end{tabular}

